Florida International University FIU Digital Commons

FIU Electronic Theses and Dissertations

University Graduate School

$11-7-2016$

\title{
An Ecological Study of the Anurans in Tea Plantations in a Biodiversity Hotspot
}

Lilly M. Eluvathingal

Florida International University, leluv001@fiu.edu

DOI: 10.25148 /etd.FIDC001204

Follow this and additional works at: https://digitalcommons.fiu.edu/etd

Part of the Animal Studies Commons, Biodiversity Commons, Other Animal Sciences

Commons, Other Ecology and Evolutionary Biology Commons, Other Life Sciences Commons,

Terrestrial and Aquatic Ecology Commons, and the Zoology Commons

\section{Recommended Citation}

Eluvathingal, Lilly M., "An Ecological Study of the Anurans in Tea Plantations in a Biodiversity Hotspot" (2016). FIU Electronic Theses and Dissertations. 3029.

https://digitalcommons.fiu.edu/etd/3029

This work is brought to you for free and open access by the University Graduate School at FIU Digital Commons. It has been accepted for inclusion in FIU Electronic Theses and Dissertations by an authorized administrator of FIU Digital Commons. For more information, please contact dcc@fiu.edu. 


\section{FLORIDA INTERNATIONAL UNIVERSITY \\ Miami, Florida}

\section{AN ECOLOGICAL STUDY OF ANURANS IN TEA PLANTATIONS IN A BIODIVERSITY HOTSPOT}

A dissertation submitted in partial fulfillment of

the requirements for the degree of

DOCTOR OF PHILOSOPHY

in

BIOLOGY

by

Lilly Margaret Eluvathingal 
To: Dean Michael R. Heithaus

College of Arts, Sciences and Education

This dissertation, written by Lilly Margaret Eluvathingal, and entitled An Ecological Study of the Anurans in Tea Plantations in a Biodiversity Hotspot, having been approved in respect to style and intellectual content, is referred to you for judgment.

We have read this thesis and recommend that it be approved.

Kenneth Feeley

Evelyn Gaiser

Joel Heinen

Karthikeyan Vasudevan

Maureen A. Donnelly, Major Professor

Date of Defense: November 7, 2016

The dissertation of Lilly Margaret Eluvathingal is approved.

Dean Michael R. Heithaus College of Arts, Sciences and Education

Andrés G. Gil

Vice President for Research and Economic Development and Dean of the University Graduate School

Florida International University, 2016 
C Copyright 2016 by Lilly Margaret Eluvathingal

All rights reserved. 


\section{DEDICATION}

This dissertation is dedicated to my parents and to the late Dr. M. S. Mayilvahanan. 


\section{ACKNOWLEDGMENTS}

I have had the honor of interacting with some of the most inspiring people I have ever met, as a part of this dissertation. To each and every one of them I am very grateful. I thank Dr. Maureen A. Donnelly for recognizing the enthusiasm in 18-year old me, and inspiring a relationship that has long transcended one of just a student and a mentor. Her patience, motivation, and inspiration, through her own example have guided me through this dissertation journey.

I thank all my committee members Dr. Evelyn Gaiser, Dr. Karthikeyan Vasudevan, Dr. Joel Heinen, and Dr. Kenneth Felley for all their support and inputs in my project. To past and present labmates at FIU, Vivian Maccacharro, Monica Isola, Seiichi Murasaki, Kelsey Reider, Luke Linhoff, Michelle Thompson, Micheal Britton, Edward Metzger III, Matt Holden, James Watling, Ralph Saporito and Steven Whitfield for all the wonderful times through the years.

All my field work in India was possible because of the infinite trust I had in my field assistant and handyman, Elangovan, a kadar tribal. When faced with elephants and gaurs not once was I left in the lurch. I thank several of my colleagues Sandeep Das, Arun Kanagavel, Sethu Parvathi, Sandeep Varma, Dr. Deepak Veerapan, and Sneha Dharwadkar for helping in various steps along the way and for encouraging me to keep going when I was stagnating.

My parents, Alice and Jemmis, embraced my project as their own and helped me at every step along the way. Sebastian, my brother has been a pillar of moral support through this project and through all my life. 
To Dr. Mayil Vahanan Muthuswami, an extra ordinary man, whose gentle yet persistant encouragement made me take up photography. I wish I could have shared this finished product with him. He will be with me in spirit through every endeavor in life. I hope to learn to conduct myself with the grace and gentleness that he showed everyday of his life. To all the people from the tea plantations of Munnar who welcomed me into their community and taught me the life lessons of being content and happy with whatever little one has and to never forget that one doesn't need to have a lot to share and bring a smile on someone else's face. I have to mention the old gentleman with the carrot stand whose handsome smile never wilted; nurse aunty, a selfless individual working for the welfare of everyone around her; and Kaka, the estate elder, whose stories about the life in the plantations would keep me occupied for hours on days which were too wet to go to field, over endless cups of black tea. 


\begin{abstract}
OF THE DISSERTATION
AN ECOLOGICAL STUDY OF ANURANS IN TEA PLANTATIONS IN A BIODIVERSITY HOTSPOT

by

Lilly Margaret Eluvathingal
\end{abstract}

Florida International University, 2016

Miami, Florida

Professor Maureen Donnelly, Major Professor

Increasing human population size is increasing the demand for resources like timber, oil, tea, coffee, and other crops. Plantation crops mimic some aspects of native habitats, and there are studies that report the presence of some native anuran biodiversity in plantations. I focused on tea plantations in the Western Ghats-Sri Lanka Biodiversity Hotspot and studied the diversity and health of anurans in different habitats found within a tea cultivation area, near Munnar region in the Western Ghats, India. The landscape includes tea bushes, native evergreen shola forest patches, and eucalyptus forest stands. I reviewed 40 studies comparing amphibian species richness in plantations and primary forests. The age of the plantation, type of plantation, presence in a biodiversity hotspot, number of species in the dominant plantation type, number of species in the paired forest habitat, and latitudinal zone of the study, did not correlate with species richness, but plantations that had periodic harvesting had higher species richness than plantations that practiced clear-cut harvesting. I tested different methods of standard amphibian sampling 
in the field season 2012 in Munnar, and found that Visual Encounter Surveys (VES) in the shola habitat and Stream Transects (ST) were the most efficient. Using the VES and ST methods, I sampled amphibians in three upland habitats (tea, shola, and eucalyptus) at four different sites, and $150 \mathrm{~m}$ of stream transects at each site, for two consecutive monsoon seasons. Fourteen species were encountered in both years and the community structure was similar across the years. The community structure at the four sites that was driven by the presence of exclusive species at each site and species composition in streams was similar across the landscape and was driven by the presence of similar species in streams across the four sites. Two hundred and sixteen anurans of 17 species, were tested for the presence of the lethal fungus Batrachochytrium dendrobatidis. The preliminary results from the Polymerase Chain Reactions were negative. My study provides baseline data for anuran diversity, composition, and health in the Munnar region of India and results of this project can be compared with tea plantations around the world. 


\section{TABLE OF CONTENTS}

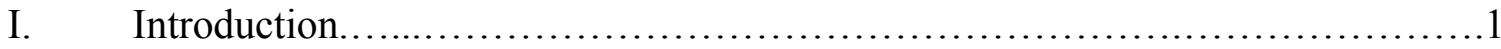

Literature Cited ......................................................4

II. CHAPTER 1: A Global Analysis of Factors Driving Amphibian Diversity in

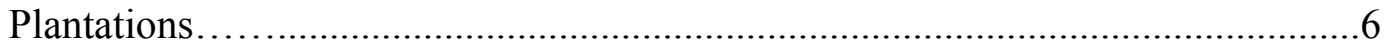

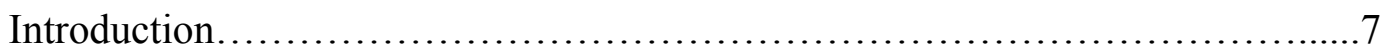

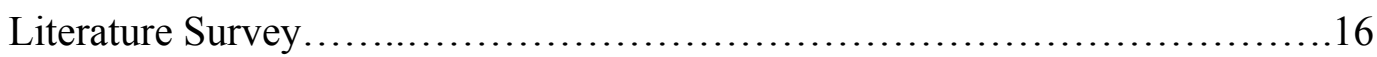

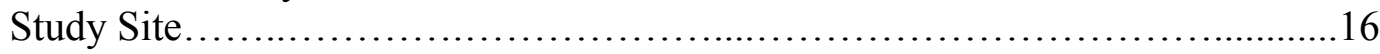

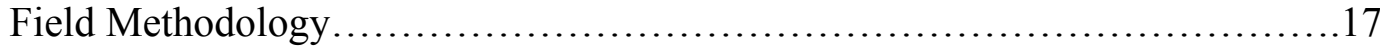

Results.............................................................. 18

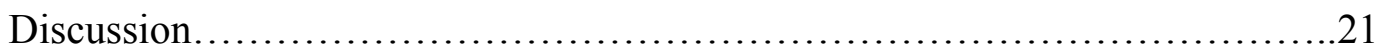

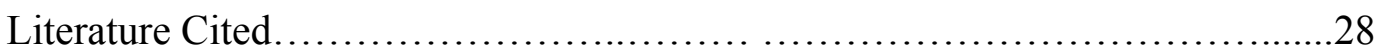

Appendix 1.1. Forty papers used for the review in chapter $1 \ldots \ldots \ldots \ldots \ldots \ldots \ldots 46$

Appendix 1.2 Table with information from 40 studies used for the review in

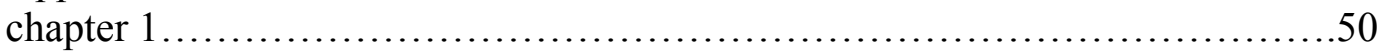

III. CHAPTER 2: A Comparative Study of Standard Methods for Surveying Anurans in Tea Plantations in the Southern Western Ghats......................51

Introduction and Background ............................................ 52

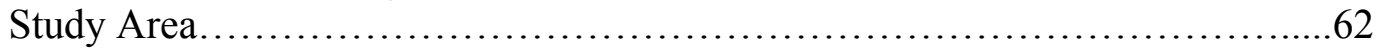

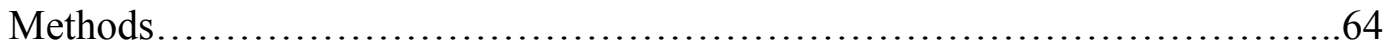

Analysis and Results...................................................67

Discussion.............................................................. 70

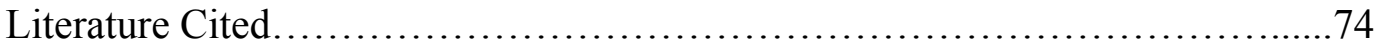

IV. CHAPTER 3: Patterns of Anuran Community Structure in a Tea Plantation

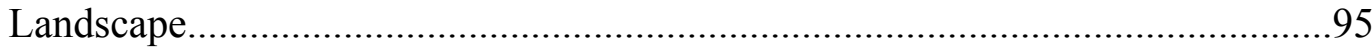

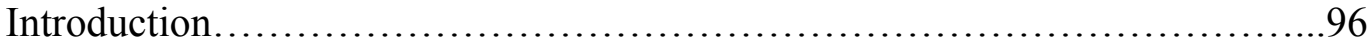

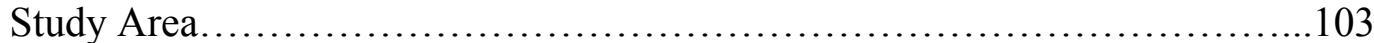

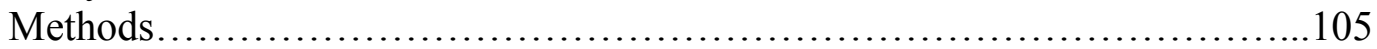

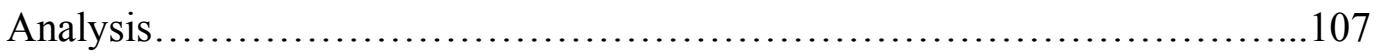

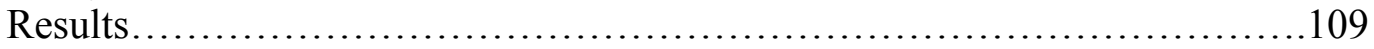

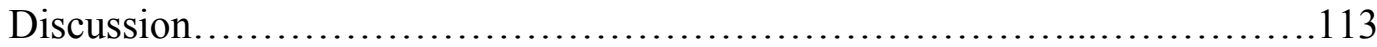

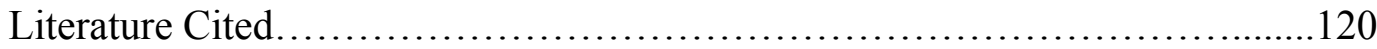

V. CHAPTER 4: Testing for Chytrid Infection in Tea Plantations in the Southern Western Ghats, India................................................ 153

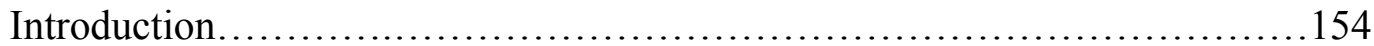

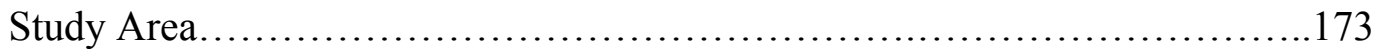

Methods........................................................... 174 
Results........................................................... 176

Discussion.............................................................. 177

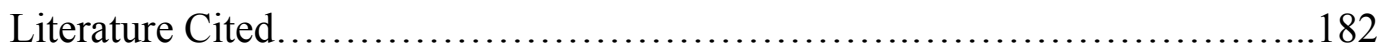

VI. CONCLUSIONS ...................................................207

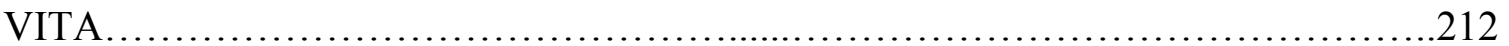




\section{LIST OF TABLES}

TABLE

PAGE

1.1. Global area of plantation forests based on 1000 acres FAO 2005)..............36

1.2. Table 1.3. Generalized Linear Model (GLM) for the number of species in plantations (SP) being described by the type of harvest (Periodic), number of species in the control forest (SF), age of plantation, and whether the plantation is present in a Biodiversity hotspot $(\mathrm{BH})$ or not............................ 37

1.3. Checklist of amphibians recorded in different habitats (eucalyptus, sholas, and tea) in tea plantations in Munnar, Kerala, India according to the IUCN threat status (Endemic to Western Ghats; Y-yes, N-no; IUCN 2016).

2.1 Complete list of species encountered from standard sampling methods from

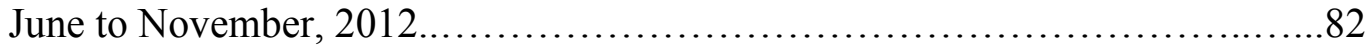

2.2 Number of species, number of individual amphibians encountered, catch person-hour or trap-hour both by habitat, and method of sampling. (VES: Visual Encounter Survey; ST: Stream Transects; FT: Funnel Traps).............83

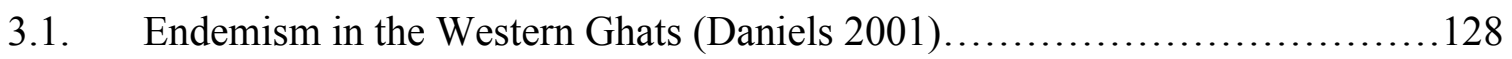

3.2. Pesticides commonly used on tea and the maximum residue levels of pesticides permitted by the European Union Regulation (European Union MRL, 2015).

3.3. All species observed by Daniels in a tea plantation along with updated names

(Daniels 2003; Frost 2016)

3.4. All species (minus juvenile Raorchestes sp.) encountered in this study from all four estate groups (LC: Least Concern; VU: Vulnerable; NE: Not Evaluated; DD: Data Deficient; NT: Near Threatened; CR: Critically Endangered; KL: Kerala; WG: Western Ghats)

3.5. All species encountered in this study using Visual Encounter Surveys (VES) from all four estate groups with information on presence and absence in each habitat and number of excusive species in each habitat in parenthesis 
3.6. Summary of average number of species and average number of individual encountered at each site and habitat type using Visual Encounter Surveys (Calculated for each site ( 3 replicates*15 minutes*repeated 18 times*2 observers) $/ 60=27$ hours per habitat

3.7. Summary of average number of species and average individual counts from each estate group for Stream transects (Calculated for each estate (3 replicates $* 30$ minutes $*$ repeated 18 times $* 2$ observers) $/ 60=54$ hours per habitat)....

4.1. Composition of Extraction buffer...................................... 194

4.2. Composition of PCR mix......................................... 195

4.3. List and number of species swabbed during the years 2012-2015 in Munnar,

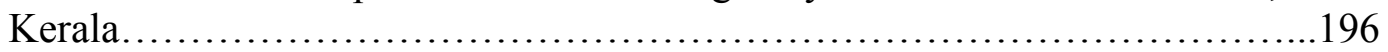

4.4. List and number of species swabbed during the years 2012-2015 in Munnar, Kerala

4.5. IUCN Red List categories all the species tested for Bd between 2012-2015 (IUCN Red List, 2015) 


\section{LIST OF FIGURES}

FIGURE

PAGE

1.1. Land suitable for palm oil plantations (IIASA, 2002; FAO 2009). 39

1.2. Location of field site within the Western Ghats and Sri Lanka Biodiversity hotspot in, Munnar, Kerala. (Map from IUCN, 2016)........................40

1.3. Number of studies in each latitudinal zone.

1.4. Location of all the 40 study sites (Map source: Conservation International Foundation, 2014).

1.5. Number of studies in different countries of the world $(\mathrm{N}=40) \ldots$

1.6. Types of plantations with comparisons of amphibians between plantations and primary forests

1.7. Number of papers published by year......

2.1. Number of amphibian species described in India from 2009 to 2015 (Frost, 2016)

2.2. Map of KDHP Co Lt. (Kanan Devan Hills Private Cooperation Limited)..... .85

2.3. Map of Kannaimallai and Periavarrai estates with transect locations (Shola, tea, eucalyptus, and a stream) were setup ...................................86

2.4. Drift fence with funnel trap image (Photos: Lilly Eluvathingal)..................87

2.5. Monthly averages of minimum and maximum temperatures for year 2012 in Rajamala tea estate, Munnar, India....

2.6. Monthly averages of rainfall and humidity for year 2012 in Rajamala tea estate, Munnar, India.

2.7. Number of individuals found in each of the habitats monthly from June to November, 2012. (Green: Shola; Red: Eucalyptus; Blue: Tea)....

2.8. Observed and Coleman's species accumulation curves for 2012 data from Munnar. Samples using using visual encounter surveys and stream transects in each of the three habitats (Shola, tea, and eucalyptus) 
FIGURE

PAGE

2.9. Number of exclusive species and number of overlapping species in different habitats types using Visual Encounter Survey (A) and stream transects (B).....92

2.10. Meta nMDS plot of pooled transect data with polygons drawn around transects using the same standard methods: Visual Encounter Surveys and Stream Transects (VES and ST; Stress: 0.2214079)....

2.11. Meta nMDS plot of pooled transect data with polygons drawn around transects in conducted in the same habitats (Tea, Shola, and Eucalyptus; Stress:

$0.2214079)$

3.1. The 25 biodiversity hotspots of the world (Conservational International, 2012).

3.2. The Western Ghats and Sri Lanka Biodiversity Hotspot with a white dot marking the study area (Map from IUCN, 2016).

3.3. Number of amphibian species described in India from 2009 to 2015 (Frost, 2016)

3.4. Map of KDHP Co Lt. with the estates where sampling was conducted (Kanan Devan Hills Private Cooperation Limited).

3.5. A KDHP map with the four estate groups (1. Vaguvarrai; 2. Rajamallay and Pettimudi; 3. Madupetty and Thenmala; 4. Silent Valley) marked (Google maps, 2016)

3.6. MetanMDS plot of similarity with ellipses drawn around samples from each year, 2013 and 2014 (Stress: 0.2510247).

3.7. Average monthly rainfall in $\mathrm{mm}(+1$ Standard Deviation) for years 2013 and 2014 in Rajamallay and Pettimudi, Silent Vally, Madupetty and Thenmala, and Vaguvarrai sites, Munnar.

3.8. Average ( \pm Standard Deviation) monthly minimum and maximum temperature in degrees Celcius for years 2013 and 2014 in the Rajamallay and Pettimudi site, Munnar.

3.9. Average ( \pm Standard Deviation) monthly minimum and maximum temperature in degrees Celcius for years 2013 and 2014 in the Silent Vally site, Munnar....143 
3.10. Average ( \pm Standard Deviation) monthly minimum and maximum temperature in Celcius for years 2013 and 2014 in the Madupetty and Thenmala site, Munnar.

3.11. Average ( \pm Standard Deviation) monthly minimum and maximum temperature in Celcius for years 2013 and 2014 in the Vaguvarrai site, Munnar.

3.12. Species encountered per month in 2013 in the upland transects 146

3.13. Species encountered per month in 2013 in stream transects 147

3.14. Species encountered per month in 2014 in the upland transects.................148

3.15. Species encountered per month in 2013 in stream transects

3.16. MetanMDS plot of similarity with ellipses drawn around the four different sites (Stress: 0.2510247)

3.17. MetanMDS plot of similarity with ellipses drawn around the sites using either VES (light green) or stream transects (light blue; Stress: 0.2510247).....151

3.18. MetanMDS plot of similarity with ellipses drawn around sites from similar upland habitats, shola (dark green), tea (light green), eucalyptus (yellow), and around sites from stream transects (light blue; Stress: 0.2510247).

4.1. Probablity of chytrid infection for Hylid amphibians globally from extrapolated maps (Olsen et al. 2013)

4.2. Life-cycle of Chytrid showing both aquatic (substrate independent) and terrestrial phases (substrate dependent) (Rosenblum et al. 2008)................200

4.3. Global odds of chytrid detection in amphibians (Olsen et al. 2013).............201

4.4. Map of predicted and observed Batrachytrium dendrobatidis detection in Asian amphibians (Swei et al. 2011) .......................................202

4.5. Map of KDHP Co Lt. Black dots mark estates were samping was done (Kanniamallay, SilentValley, Madupatty, Rajamallay, and Vagavurrai; Kanan Devan Hills Private Cooperation Limited)

4.6. Monthly averages of Rainfall and humidity for year 2012 in Rajamala tea estate, Munnar, India 
4.7. Maximum and minimum temperatures on days when samples were collected along with a line to represent the highest temperature that $\mathrm{Bd}$ spores can

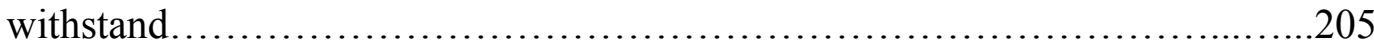

4.8. Number of swabs collected per month between 2012 and $2015 \ldots \ldots \ldots \ldots \ldots . . .206$ 


\section{ABBREVIATIONS AND ACRONYMS}

ANOSIM Analysis of Similarity

ASL Above Sea Level

Bd Batrachochytrium dendrobatidis

BdGPL Batrachochytrium dendrobatidis global panzootic lineage

Bsal Batrachochytrium salamandrivorans

FAO Food and Agriculture Organization

GAA Global Amphibian Assessment

HCV High Conservation Value

KDHP Kanan Devan Hills Tea Plantation Company Private Limited

MHC Major Histocompatibility Complexes

nMDS non-metric Multi-Dimensional Scaling

IACUC Institutional Animal Care and Use Committee

IUCN International Union for Conservation of Nature and Natural Resources

PCR Polymerase Chain Reaction

ST Stream Transect

VES Visual Encounter Survey

WG Western Ghat 


\section{Introduction}

Global flora and fauna face several pressing threats and it is essential to collect data which increases our knowledge of individual species, as well as communities of species in different locations, to make successful conservation plans (Wake and Vredenburg 2008). The threats have been reported to be more severe for amphibians compared to other verebrates, and some of the threats amphibians face include fragmentation and loss of habitat, pollution and increase in pesticide use, infection by chytrid fungus and other diseases, dam and water management systems, ultraviolet $\beta$ radiation, and the introduction of alien species (Alford and Richards 1999; Bickford et al. 2010; Blaustein and Kiesecker 2002; Cushman 2006; Hayes et al. 2010; Nowakowski et al. 2016; Stuart et al. 2004; Whitfield et al. 2007; Whitfield et al. 2013).With an increasing human population, our agricultural lands are under constant pressure to increase production and at the same time more land area is being converted to agricultural purposes. Though most biodiversity conservation plans are executed in protected areas, in the past few decades there have been multipe studies to investigate the role played by plantation landscapes in supporting amphibian diversity (Brockerhoff et al. 2008; Felton et al. 2010; Folt and Reider 2013; Gardner et al. 2007).

In India, commercial tea production is spread across 14 states (Shah and Pate 2016). However, there are very few studies that look at the diversity of anurans in tea plantations (Daniels, 2003) despite the fact that many tea plantations occur in the Western Ghats and Sri Lanka biodiversity hotspot. My research examined the role played by tea plantations in supporting anuran diversity in the state of Kerala, India, in the Western Ghats mountain range. India has seen an increase in anuran species descriptions since 2000, 
however, not as much work is focused on studying the community level studies of these species, especially in agro-economic landscapes (Bossuyt et al. 2004; Frost 2016). My research was conducted in the Munnar region of the Indian part of the Western Ghats and Sri Lanka biodiversity hotspot; a region designated as such, because of its high biodiversity, and because of the presence of several anthropogenic stressors in the region (Bossuyt et al. 2004; Myers et al. 2000; Myers 2003). The landscape in my study area was modified into tea plantations starting in the late 1870s by the British and has been privately owned since 1878. The current management scheme started in 2005 (Daniels 2003). The Munnar area is lacking in peer-reviewed species lists and information on anuran communities from the tea landscape, though several new species have been described from the region in the past 10 years (Frost 2016).

There are four chapters in the present dissertation: Chapter 1: A global analysis of factors driving amphibian diversity in plantations; Chapter 2: A comparative study of standard methods for surveying anurans in tea plantations in the southern Western Ghats; Chapter 3: Patterns of community structure in tea plantations in Munnar, India; Chapter 4: Testing for chytrid in tea plantations in the southern Western Ghats, India. In Chapter one I reviewed studies comparing amphibian diversity in plantations to amphibian diversity in a natural forest habitat nearby, and a case study from of amphibian species richness from four estates in the tea plantation landscape in southern India. From each study, I extracted information about the age of the plantation, the type of plantation, the type of harvesting employed (complete or periodic), whether it was in a biodiversity hotspot or not, the number of species in the dominant plantation type, the number of species in the paired forest habitat, and which latitudinal zone the study was conducted in. Using data obtained 
from the different standard amphibian sampling methods and opportunistic encounters during 2012, at elevations between $1500 \mathrm{~m}$ and $2000 \mathrm{~m}$ asl in the Munnar district of Kerala, India, I made a checklist of anurans found in the tea plantations in Munnar between 1500 and $2000 \mathrm{~m}$ asl and compared these data to the amphibian diversity information obtained from other studies. In Chapter 2, I sampled and used the data obtained from the field year 2012, to rate the efficiencies of different standard methods of surveying amphibians in three different habitats (tea, shola forests, eucalyptus forests). I used nocturnal and diurnal, upland Visual Encounter Surveys (VES), VES in Stream Transects (ST), and funnel traps with drift fences standard methods. Using the most efficient standard amphibian surveying methods obtained from Chapter 2, I surveyed amphibian diversity and composition across four sites in the tea plantation landscape of Munnar, India, during the monsoon seasons of two years: 2013 and 2014. I compared the community composition across the four sites, and across three different habitat types (shola, tea, and eucalyptus) in the landscape using data collected in the years 2013 and 2014. In Chapter four, I focused on testing anurans in the tea plantations of Munnar for the presence of a known amphibian pathogen. Between 2012 and 2015, I swabbed anurans in the tea plantation landscape and tested the swabs for the presence of the global and Asian strain of the fungus Batrachochytrium dendrobatidis $(B d)$. The present study provides baseline data about the richness, abundance, and health of anuran communities in a tea-dominated landscape in the Munnar area, of the southern Western Ghats, India. 


\section{Literature Cited}

Alford, R. A., and S. J. Richards. 1999. Global amphibian declines: A problem in applied ecology. Annual Review of Ecology and Systematics. 30:133-165.

Bickford, D., Howard, S. D., Ng D. J. J., and J. A. Sheridan. 2010. Impacts of climate change on the amphibians and reptiles of Southeast Asia. Biodiversity Conservation. 19:1043-1062.

Blaustein, R. A., and M. J. Kiesecker. 2002. Complexity in conservation: Lessons from the global decline of amphibian populations. Ecology Letters. 5:597-608.

Bossuyt, F., Meegaskumbura, M., Beenaerts, N., Gower, D.J., Pethiyagoda, R., Roelants, K., Mannaert, A., Wilkinson, M., Bahir, M.M., Manamendra-Arachchi, K. and Ng, P.K., 2004. Local endemism within the Western Ghats-Sri Lanka biodiversity hotspot. Science. 306:479-481.

Brockerhoff, E.G., Jactel, H., Parrotta, J.A., Quine, C.P. and Sayer, J., 2008. Plantation forests and biodiversity: Oxymoron or opportunity? Biodiversity and Conservation. 17:925-951.

Cushman, S.A., 2006. Effects of habitat loss and fragmentation on amphibians: A review and prospectus. Biological Conservation. 128:231-240.

Daniels, R. J. R. 2003. Impact of tea cultivation on anurans in the Western Ghats. Current Science. 85:1415-1422.

Felton, A., Knight, E., Wood, J., Zammit, C. and Lindenmayer, D., 2010. A metaanalysis of fauna and flora species richness and abundance in plantations and pasture lands. Biological Conservation. 143:545-554.

Folt, B. and Reider, K.E., 2013. Leaf-litter herpetofaunal richness, abundance, and community assembly in mono-dominant plantations and primary forest of northeastern Costa Rica. Biodiversity and Conservation. 22:2057-2070.

Frost, D. R. 2016. Amphibian Species of the World: An Online Reference. Version 6.0 (August, 2016). http://research.amnh.org/herpetology/amphibia/index.html. American Museum of Natural History, New York, USA.

Gardner, T.A., Barlow, J. and Peres, C.A., 2007. Paradox, presumption and pitfalls in conservation biology: The importance of habitat change for amphibians and reptiles. Biological Conservation. 138:166-179. 
Hayes, T.B., Falso, P., Gallipeau, S. and Stice, M., 2010. The cause of global amphibian declines: A developmental endocrinologist's perspective. The Journal of Experimental Biology. 213:921-933.

Myers, N., Mittermeier, R.A., Mittermeier, C.G., Da Fonseca, G.A. and Kent, J., 2000. Biodiversity hotspots for conservation priorities. Nature. 403:853-858.

Myers, N., 2003. Biodiversity hotspots revisited. BioScience. 53:916-917.

Nowakowski, J. A., Watling, J. I., Whitfield, S. M., Todd, B. D., Kurz, D. J., and M. A. Donnelly. 2016. Tropical amphibians in shifting thermal landscapes under land use and climate change. Conservation Biology. DOI:10.1111/cobi.12769.

Shah, S.K. and Pate, V.A., 2016. Tea production in India: Challenges and opportunities. Journal of Tea Science Research. 6:1-6.

Stuart, S.N., J.S. Chanson, N.A. Cox, B.E. Young, A.S.L. Rodrigues, D.L. Fischman, and R.W. Waller. 2004. Status and trends of amphibian declines and extinctions worldwide. Science. 306:783-1786.

Wake, D. B. and V. T. Vredenburg, 2008. Are we in the midst of the sixth mass extinction? A view from the world of amphibians. Procedings of the National Academy of Sciences. 105 (suppl. 1):11466-11473.

Whitfield, S. M., Bell, K. E., Philippi, T., Sasa, M., Bolaños, Chaves, F. G., Savage, J. M., and M. A. Donnelly. 2007. Amphibian and reptile declines over 35 years at La Selva, Costa Rica. Proceedings of the National Academy of Sciences. 104:8352-835.

Whitfield, S.M., Geerdes, E., Chacon, I., Ballestero Rodriguez, E., Jimenez, R.R., Donnelly, M.A. and Kerby, J.L., 2013. Infection and co-infection by the amphibian chytrid fungus and ranavirus in wild Costa Rican frogs. Diseases in Aquatic Organisms. 104:173-178. 


\section{CHAPTER 1}

A Global Analysis of Factors Affecting Amphibian Diversity in Plantations

Abstract

Anthropogenic conversions of natural areas to agriculture and monoculture plantations are a large threat to flora and fauna, especially in biodiversity hotspots which harbor large numbers of endemic species. Plantations in the tropics are established in areas characterized by high species richness. However, studies on the biodiversity present in these systems are only a few decades old. It is becoming clear that plantations can be hospitable to many species, and are used by some native organisms. Plantations in the tropics tend to support some native species that are endemic and have narrow distribution ranges indicating a potential high conservation value. Papers published on amphibian diversity in plantations were examined for factors affecting the number of species, with a focus on tropical plantation systems. Forty papers comparing amphibian species richness in plantations and nearby primary forests are compared with each other and to preliminary data on anurans obtained from an active tea plantation in Kerala, India. The tea plantation study site (1500-2000m asl) is in the Western Ghats and Sri Lanka biodiversity hotspot. Factors like age of the plantation, type of crop, and harvesting regime did not explain the richness of amphibian species in plantations in the tropics, likely because of the variations in crop types, geographic locations of the studies, and the methods used used to harvest crops. Amphibian species occur in the plantations in each study site, and generally plantations are species poor compared to the forested reference sites. Of the 25 species encountered in the tea plantations in Munnar, Kerala, all but one species is endemic to the Western Ghats. Nine species are in the first three threat 
categories (Critically endangered, Threatened, and Vulnerable) of the IUCN red list. Conservation practices that can be implemented to protect amphibians without affecting tea production, including selective protection of breeding microhabitats, may increase the attractiveness of tea to an increasingly socially conscious, international market. With the global area under plantations increasing annually, understanding how wildlife uses plantations can provide managers with information on the biodiversity value of their property.

Key words: Biodiversity Hotspots, conservation, plantations, tea, tropics

Introduction

Increasing industrialization and globalization are the leading drivers of several anthropomorphic changes on earth (Felton et al. 2010; Gardner et al. 2007). These alterations are in turn linked with increased logging, cattle ranching, and plantations, which are among the main drivers of conversion of tropical forests to other uses (Brockerhoff et al. 2008; Laurance 2014). According to the Oxford Dictionary there are two definitions of the word plantation: 1) An estate on which crops such as coffee, sugar, and tobacco are cultivated by resident labor, and 2) An area in which trees have been planted, especially for commercial purposes (Oxforddictionaries.com 2016). The term plantation is now used to describe stands of pine, eucalyptus; cash-crops like tea, cashew, coffee; spices such as cinnamon, and cardamom; oil producing crops like groundnuts, and oil palm, and other crops such as sugar cane, banana, and pineapple. Data collected by 
the Food and Agriculture Organisation of the United Nations (FAO) show that the global annual rate of change to planted forests in the world has increased by $2.09 \%$ in the past 10 years, up from $1.88 \%$ in the decade before (Table 1.1; Global Forest Resources Assessment 2005; FAO 2011). With a growing human population, it is clear that existing plantations will not suffice, which had resulted in the establishment of additional plantations. Many of the world's plantations are found in Asia, Central America, and South America in the tropics, which have climatic conditions that are conducive to the management of large plantations (Felton et al. 2010; Gardner et al. 2007). Most of the land that is considered to be promising for conversion to plantations is located in the tropics (Figure 1.1; IIASA 2002), and overlaps with several 'Biodiversity Hotspots' (Myers et al. 2000). In the past, biologists have often considered plantations to be "green deserts" with a hostile environment for flora and fauna, and yet in the past few decades there has been a change in this attitude because of several studies showing that plantations around the world provide refuge for a subset of the native biota (Brockerhoff et al. 2008; Felton et al. 2010; Folt and Reider 2013; Gardner et al. 2007). Of all the extant amphibian species described, Nori et al. (2015) reported that approximately 25\% are found outside protected areas, and an added $18 \%$ have less than $5 \%$ of their population in protected areas. Asia had the fastest rate of increasing land under plantation cover of $2.8 \%$ from 2000 to 2005 (FAO 2006). From Asia, the two families Nasikabatrachidae and Micrixalidae, (both endemic to the Western Ghats), had the largest percentage of species found outside protected areas (Nori et al. 2015). 
Plantations bring to mind clearing of vast expanses of land, monocultures, non-native plants, genetically modified crops, complete harvesting, soil abuse, substantial additions of chemicals, disease breakouts, and an increasing demand for various products, fueling an increasing pressure on the lands that are already under cultivation. Wilcove and Koh (2010) warned that plantations like oil palm are very profitable for the poor communities in Southeast Asia, as they are used in several different products, and that demand for organically grown palm oil is very low, with countries like China and India being the largest markets. With these negative effects, and the global area under plantation increasing and with exponential human growth, the rate of increase in area converted to plantations is only going to increase annually (FAO 2009; FAO and JRC 2012; FAO 2015). The controlled application of various agrochemicals is a factor to be taken into consideration while conducting any ecological study in a plantation setting (Ghose et al. 2014; Johnson et al. 2013). With the increase in area under plantations, it is important to understand how different life history stages of amphibians are affected by different concentrations and combinations of commonly used herbicides, weedicides, pesticides, and fertilizers.

The value of plantations versus the value of the diversity that is still supported by the area under plantation is difficult to estimate, since most plantations are usually areas that are written off as green deserts, and because it is hard to estimate the value of an individual species (Brockerhoff et al. 2008; Gardner et al. 2007; Hudson et al. 2014). The economic value of the ecological role of biodiversity and of individual species is largely unquantified and even if valued, these valuation methods are sometimes controversial 
(Allsop et al. 2008; Edwards and Laurance 2012; Ghazoul 2005; Winfree et al. 2011). In several situations, plantations are less severe in their manipulation of nature than is a complete urban environment. As the total area under cultivation continues to increase, the effects on biodiversity should be documented, and the present study compares diversity in altered tropical ecosystems to nearby patches of remnant forests.

There have been several studies conducted in plantations around the world that examine the diversity of a variety of plants and animals in these manipulated systems (Brockerhoff et al. 2008; Felton et al. 2010; Gardner et al. 2007; Palacios et al. 2013; Thompson et al. 2003; Thompson et al. 2015). Hudson et al. (2014) started the PREDICT database of global biodiversity data with over 28,000 species from 78 countries, to develop models that estimate effects of humans on local biodiversity. Lieberman (1986) recorded that disturbed cacao plantations had low species richness, high abundance, and low diversity, compared to natural forests of the La Selva Biological Station in Costa Rica. Slowinski et al. (1987), reported more individuals of some species of leaf-litter amphibians and reptiles, in abandoned cacao plantations during nocturnal surveys, than during daytime surveys, suggesting that these species showed a diel pattern in their use of leaf litter. Heinen (1992), found that old growth cacao plantations were intermediate, to younger cacao plantations and primary forests at La Selva Biological Station, in Costa Rica, both in herpetofaunal diversity as well as in leaf litter depth, that supports a positive relationship between litter depth and species richness. Gardner et al. (2007) reported that 23 out of 157 studies examined herpetological diversity in plantations between 1945 and 2006 and the majority of which are from the New World (Gardner et al. 2007). In a study 
of Physalaemus lisei, Becker et al. (2007), reported that the abundance of the species in monocultures of Araucaria angustifolia, Pinus, and eucalyptus, was similar to that in natural Araucaria forests. In Canada, Thompson et al. (2003), reported that amphibians were poorly represented in studies of plantations. In a review of global studies comparing diversity across plantations and pasture land, Felton et al. (2010), found that amphibians and reptiles were more diverse in plantations than in pasture land, however they warned against making this general assumption as there were several other factors that needed to be accounted for, such as, management practices, field methods, and the kind of crop in question. Sreekar et al. (2013), using photographs, captured 45 out of 59 marked lizards (Draco dussumieri), from a two-hectare areca-nut plantation to estimate the population density of the lizards in the plantation. Rathod and Rathod (2013) reported 19 species of amphibians from organic coffee plantations, and 15 species from protected sacred groves from the Kodogu region of Karnataka, India, with comparable abundances in the two habitats. A study comparing the reproductive habitats available for a frog from Ireland in conifer plantations, bogs, roadsides drains, and clear cut areas showed that the highest use and output in reproductive activity was seen in pools that were near the roadside and the clear felled areas (Dibner et al. 2014). Popescu and Hunter (2011), reported that the mature forests, recent clear cut forests, 11-year-old, and 20-year-old regenerated forests of conifer plantations offered different levels of resistance to the migration of the juvenile wood frogs (Lithobates sylvaticus), with the anurans showing a strong preference to forests with the thickest canopy cover. While the presence of diversity in plantations is important, it is also important to study of the health of the individuals ecountered. After three years of sampling, Gurushankara et al. (2007) reported 35 individual frogs with 
visible abnormalities from 754 frogs encountered in coffee plantations. Abnormalities observed, included, missing digits, missing eyes, and reduced limb length (Gurushankara et al. 2007).

On the other hand, some species are more abundant in plantations. Species like Geobatrachus walkeri, a leaf-litter specialist, seem to thrive in plantations, with much higher abundances in the plantations than in natural forests (Martínez Baños et al. 2011). The thick leaf-litter microhabitat available to them in the plantation seems comparable to the litter habitat which they usually use, and the chemical manipulations did not appear to have any observable affect on the reproductive health measured by testicular and follicular growth (Martínez Baños et al. 2011). A pit-fall trap study showed the presence of four, four, and three species of common anurans in agro-systems of corn, rubber, and soy fields, in Southern Brazil, respectively (da Silva et al. 2009). All the species found in these plantations were known generalists that feed on a wide variety of insects that are usually associated with the agricultural fields (da Silva et al. 2009). The presence of nine species of anurans in rice field quadrats near the Pantanal wetland in Brazil, also shows that monoculture agro-systems seems to provide a refugee to a subset of the native anuran fauna (Piatti et al. 2010). However, all the nine species reported in these rice fields are known to be habitat generalists, suggesting that rice fields offer a homogenous habitat that only supports generalist species (Piatti et al. 2010). Populations of Rhinella schneideri in Brazil showed no reduction in gene flow and migrations rates even in study sites with sugarcane plantations as the dominant habitat (Arruda et al. 2011). A single study from Santiago Jalahui, Oaxaca reports the presence of five species of amphibians 
from a shaded coffee plantations landscape (Moguel and Toledo 1999) which is quite poor compared to amphibian diversity (23 species) reported by Lazcano-Barrero et al. (1992), from the Lacandon Rainforests. Adults of the Coqui Frog (Eleutherodactylus coqui) were equally abundant in native forests and eucalyptus plantations, and their abundance seemed to depend more on the structural complexity of the plants than on the specific plant species (Fogarty and Vilella 2003). In a 2013 review, 37 cases (in 279 publications) of amphibian diversity in forests versus plantations were compared from 14 countries (mostly from Latin America and the Caribbean) and in 25 of these cases, the species diversity in plantations was reported to be reduced to that of native forests (Palacios et al. 2013). The same study reported that there was no significant difference in the abundance of amphibians between plantations and forests, suggesting that the though in poor in species richness, plantations provided a reasonable refugee for the species that were present. Murrieta-Galindo et al. (2013), found $46 \%$ of the amphibian in the cloud forests, represented in nearby shaded and non-shaded coffee plantations in the highly agricultural Veracruz region of Mexico. The direct developing family of anurans, Craugastoridae was found in all the sites and the authors speculated that independence from aquatic breeding sites might be the reason that species from this family are found in plantations where the water bodies might be contaminated (Murrieta-Galindo et al. 2013).

Tea is popular global beverage and is grown in several countries (China, India, Turkey, and Tanzania) around the world in monoculture plantations. China produces the largest quantity of tea globally, with an output of 1.9 million tons, which is over $38 \%$ of the world total, and is followed by India, producing 1.2 million tons (Chang 2015). Eighty 
percent of global tea export is from the top five highest tea producing countries: China, India, Kenya, Sri Lanka, and Turkey (Shah and Pate 2016). Commercial tea production in India occurs in 14 states (Shah and Pate 2016). Tea, is a tree which grows in the tropics and sub tropics, and all commercial tea is produced from a single species, Camellia sinensis (Chang 2015; Shalleck 1972). The ideal temperature range for growing tea is between $20^{\circ}$ and $30^{\circ} \mathrm{C}$ and the plant requires around $150-300 \mathrm{~cm}$ of annual rainfall which is ideally distributed evenly throughout the year (Chang 2015; Shalleck 1972). Even though high rainfall is beneficial for the tea bushes, stagnation of water is not, therefore tea is usually grown along the sides of mountain where the rainwater can run off. Tea thrives in soils which are slightly acidic and are rich in organic matter (Shalleck 1972). High humidity and morning mist encourage the growth of new leaves but they also make the plant susceptible to several fungi (Shalleck 1972). Tea plants are regularly sprayed with chemicals to keep fungi and other diseases at bay (Chang 2015; Shalleck 1972). Short term observations reveal changes in distribution patterns of amphibians because of harsh pesticide applications in tea plantations in South India (Daniels 1991, 1992, 2003). Daniels (2003) reported 13 amphibians from a short 11 day study in a tea plantation in Vaalparai, Tamil Nadu, India. Eleven species were reported from streams flowing into grassy swamps that were created during the rains (Daniels 2003). Krishna et al. (2005) reported six species of anurans from native forests streams, eight species from cardamom forests streams, and six species from streams in coffee plantations. Micrixalus saxicola was most abundant in native forests, Nyctibatrachus sp. in cardamom plantations, and Rana temporalis was the most common frog in coffee plantations. A month-long study from a tea plantation which shifted to organic cultivation five years ago in Sri-Lanka, 
observed ten species of amphibians, including six endangered species in tea bushes (Kottawa-Arachchi et al. 2014). At elevations above $2000 \mathrm{~m}$ asl, the productivity of tea is modelled to increase up to $37 \%$ with the doubling of carbon dioxide from $370 \mathrm{ppm}$ to 600ppm as result of global warming (Wijeratne et al. 2011).

I review studies in plantations where amphibian diversity was measured and compared to that of nearby natural forests. I also examined these data to determine what might explain why some plantations appear to be better refuges than others. I predicted that older plantations would support higher species richenss compared to younger plantations. I also predicted that factors like harvest methodology, and organic management practices would support high species richness. A list of suggestions for why some species survive in plantations may help create a set of guidelines for managers to design biodiversityfriendly plantations without compromising their productivity and in the process gaining green certifications from Non-Governmental Organizations. I compared my results from two different manipulated habitats: eucalyptus stands and tea fields to natural shola forests, in an actively managed tea plantation in Munnar, located in the southern Western Ghats. I also provided an updated version of an existing species list from a nearby National park. Finally, I examined my case study in the context of the data obtained from reviewing published papers comparing amphibian species richness between plantations and primary habitats. 


\section{Literature Survey}

In order to find drivers for anurn species richness in plantations across the globe, a search was conducted with the Web of Science TM core collection search engine for the key words amphibian + plantations. The data set was queried in May 2015 and then in February 2016. Out of 97 papers obtained by the search only 36 papers compared amphibian diversity between a primary forest and a plantation of some sort and also provided species richness information from both habitat types. I also looked at all the papers in the literature cited in each of the 36 papers and expanded the data set to 40 papers. These 40 papers fit the initial search criteria and (Appendix 1.1) compared amphibian diversity between a plantation area and a primary habitat. Information on the location of the plantation, country, type of crop, method of harvesting, type of management, year of the start of the plantation, the earliest year of harvesting and species richness in each habitat type was collected from each paper.

From each of the 40 papers, location, year of the establishment of the plantation, year of earliest sampling, number of amphibian species in the dominant plantation, number of amphibian species in primary forest, intensity of harvesting (Periodic or complete), and type of plantation (organic or not) was recorded and summarized.

\section{Study Site}

A survey of anurans was study was conducted near the town of Munnar, in the state of Kerala in the Southern Western Ghats of India from 2012-2014 across three habitat types: 
tea, shola forest, and eucalyptus stands. The Munnar mountain range in the Munnar Forest Division has over $106 \mathrm{Km}^{2}$ of reserve forest, most of which is interspersed among tea plantations (Figure 1.2). Munnar receives rainfall both during the Southwest and the Northeast monsoons. The Southwest monsoons account for over $80 \%$ of the annual precipitation which is usually between $1200-1500 \mathrm{~mm}$ and occurs during June and July. The rest of the precipitation $(400-800 \mathrm{~mm})$ is received during Northeast monsoon which from October to November (weather-and-climate.com). I conducted amphibian surveys using standard methods in the Kanan Devan Hills Tea Plantation Company Private Limited (henceforth KDHP; $10^{\circ} \mathrm{N}$ and $77^{\circ} \mathrm{E}$ ) located in the Idukki district, of Kerala, in the Southern Western Ghats.

Field Methodology

At the field site in Munnar, all anuran species encountered along transects in different habitats were recorded, in order to find the species richness supported by the tea plantation landscape. Nocturnal Visual Encounter Surveys (VES) and Stream transect standard methods were used for sampling amphibians (Crump and Scott 1994). I set up $25 \mathrm{~m}$ transects in all three habitat types. Each transect was marked every five meters using flagging tape. The VES method involved two people walking along the transect and searching carefully for frogs, $1 \mathrm{~m}$ on either side of the transect line and up to $2 \mathrm{~m}$ above the ground for 15 minutes (Crump and Scott 1994). The transects were sampled at night (19:00 hrs-00:00hrs). The starting point of each transect within a particular habitat, was at least five meters away from a different habitat type. Twenty-five meter stream transects 
were set up in the tea and shola habitats. Stream transects were marked every $5 \mathrm{~m}$ using flagging tape on vegetation in the riparian zone. Two people walked in the middle of the stream searching carefully for frogs, $1 \mathrm{~m}$ on either side of the transect line and up to $2 \mathrm{~m}$ above the ground for 15 minutes (Crump and Scott 1994). The transects were conducted during the day (09:00 hrs-12:00hrs) and at night (19:00 hrs-00:00hrs using head lamps). All streams were from independent drainages. I also added to this list generated by standard sampling, all the amphibian species that were opportunistically encountered in the tea plantations that were being surveyed. All the habitats (shola, tea, and eucalyptus) that each species was spotted in, even if just an opportunistic observation, were included.

Results

Of the 40 studies included in my sample, 30 of the study sites were in biodiversity hotspots and 30 studies were in the tropics (Figure 1.3). The studies were distributed across 19 countries with the largest number of studies in Costa Rica, followed by Mexico (Figure 1.4). Australia, Canada, Colombia, Ecuador, India, Madagascar, Nicaragua, Nigeria, Borneo, and Uganda had only one study that compared amphibian from a plantation to a native forest (Figure 1.5). The most common kind of plantations were eucalyptus, coffee, and various kinds of pines and conifers. The other plantation types included in the review were cacao, oil palm, rubber, corn, sugarcane, coconut, cardamom, cashew, and tea (Figure 1.6). The 40 papers were published between 1992 and 2016 with an increase in the number of publications after 2011 (Figure 1.7). Some of the studies (13) involved complete one-time harvesting of the crop (e.g., eucalyptus, sugarcane) and 
in many others (27) periodic harvesting of plant products occurred (e.g., coffee, tea). Only three (cardamom and cacao) of the 40 plantations in the study followed organic practices (Deheuvels, et al., 2014; Krishna, et al., 2005). In two of the studies of organic farming, the native forests had greater species richness than the organic plantations. The age of a plantation was calculated as the year of start of the plantation to the time of the study and the difference in species richness was calculated as the number of species in a nearby primary forest and the number of species in the dominant plantation in the study. In four of the 40 studies, there was no difference in species richness between the plantation and native forests, and in four studies, the species richness was greater in the plantations than in the forest and in the remaining 31 studies the species diversity was greater in the forest than in plantations. After standardizing (dividing total number of excess species by the total number of studies with high species richness in each case) for the number of plantations, primary forests showed 7.55 species more than plantations. The four studies in which plantations had higher species richness harbored 2.75 species more than the primary forest. A paired t-test for the number of total number of species in plantations versus the total number of species in native forests indicated higher species richness in native forests $(\mathrm{p}>0.003)$. When studies were divided into those with complete harvesting $(\mathrm{n}=13)$ and periodic harvesting $(\mathrm{n}=27)$, and there was no difference in the difference in species richness between the two harvest patterns $(\mathrm{p}=0.48)$. However, three (two pine, and one black spruce plantation) out of the four studies in which the total number of species was greater in the plantation than in the nearby native forest were from the complete harvesting regime. These three plantations were in the temperate zones and from areas with low amphibian species diversity (Mitchell et al. 1997; Vonesh 2001; 
Waldick et al. 2014). The Pearson's correlation coefficients between age of plantation and number of species in the plantation, as well as, the difference in number of species between primary forest and dominant plantation are -0.056 and 0.103 , respectively. A generalized linear model showed that only the number of species in the control forest sites and the harvest method were significant factors that correlated with the number of species in plantations. Location in a biodiversity hotspot, and age of the plantation were not significantly correlated with the number of species in each plantation (Table 1.2). Thus, plantations practicing periodic harvesting appear to be slightly better for amphibian species diversity than those practicing complete harvesting in the tropics.

In my study of amphibian diversity in Munnar, India, 25 species were found in the tea plantation landscape between 1500 and $2000 \mathrm{~m}$ asl. Eighteen species were found in remnant shola forest patches (Table. 1.3). Beddomixalus bijui was found exclusively on tea bushes. One individual of Nyctibatrachus acanthodermis was found in a stream flowing though a eucalyptus forest patch. Five species were found exclusively in patches of shola forest. Of the 25 species I encountered, nine species are in the most endangered categories of the IUCN red list (IUCN 2016), and all except one (Duttaphrynus melanostictus), are endemic to the Western Ghats. Raorchestes chlorosomma, Raorchestes munnarensis, Raorchestes griet, Rhacophorus pseudomalabaricus are Critically Endangered species. All of the four species of anurnas were described since the year 2000. Another nine species are designated as either data deficient or not evaluated by the IUCN (Table. 1.3; IUCN 2016). 


\section{Discussion}

My literature review revealed that no single driver other than harvest method drove species richness in plantations around the world. There were few studies directly comparing amphibian species richness in plantations and primary forests. The 40 studies conducted globally were from several different countries and ten countries only had a single study. Barring Costa Rica, most of the countries which had more than four studies were conducted in North America. There are many plantations in tropical biodiversity hotspots, which are not represented in biodiversity studies, and these are areas that are already known to harbor a high number of species which make them high priority areas for conservation (Myers 2000). There were fourteen different crops under cultivation across these 40 studies, and of these, 14 were designated as forestry plantations that planted a mix of several different kinds of conifers. The studies reviewed in the chapter are representative of the diversity of the plantation industry, also reflected in earlier reviews (Felton et al. 2010; Palacios et al. 2013). The harvesting methods vary among plantations and in several papers specific details about the harvesting process are missing. I expected the scale of scale of harvesting to have a strong effect on the species numbers and their abundances. However, this review showed no significant difference in the number of species from plantations that were periodically harvested or completely harvested at fixed intervals. However, three of the four studies that reported increased amphibian richness in the plantations compared to forests were from the temperate zone, had long growing periods, and were from areas with low species richness (Mitchell et al. 1997; Vonesh 2001; Waldick et al. 1999). There was no significant correlation between 
the age of a plantation and the number of amphibian species found in it. There was no significant relationship between the age of the plantation and the species richness found exclusively in the primary forests. The result suggests that the factors I addressed in my review do not affect species richness in plantations. The different sampling protocols used in each of the plantations with different crops and harvesting characteristics make it difficult to group studies together, though plantations practicing periodic harvesting supported slightly more amphibian species than plantations which practiced clear-cut harvesting (Table. 1.2). Only four studies showed higher species diversity in plantations compared to adjacent primary forest. Gardner et al. (2007) reported the same trend with most studies showing a reduced species richness measure in plantations compared to native forests with two exceptions to the pattern. Loehle et al. (2005) and Vonesh (2001) advised taking into account factors like complexity of the habitat available to anurans as a key factor supporting diversity found in plantations. None of the studies showed the complete absence of amphibians in plantations, and all plantations in the papers reviewed supported a subset of native species. As suggested in several publications, researchers need to provide plantation managers with information that encourages them to run their operations in a manner that can help sustain the biodiversity is remaining on their property (Felton et al. 2010; Gardner et al. 2007; Palacios et al. 2013). The information provided to managers needs to include checklists of species found on their property and the microhabitats within the plantations that species use. Advice on sustainable techniques may appear obvious to the research community but can be ignored in profitoriented industries. Das et al. (2006) reported that the Munnar grid was an irreplaceable site for species conservation, in a study modelling the importance of an area determined 
on surrogates, such as the presence of endemic plants and vertebrates. From the tea plantations sampled in Munnar, Kerala, we report 25 species of anurans, of which nine are endangered according to the IUCN Red List (IUCN 2016). The Munnar tea plantations are over 140 years old and this might explain why the tea harbors several anuran species. Sixteen of the species at our site have been described since the year 2000 , and there is not much published information about their basic biology. All, but one of the 25 species are endemic to the Western Ghats, and several of them are currently known to be endemic to Munnar. Ten of these 25 species are from the genus of direct developing frogs, Raorchestes that do not require an aquatic habitat for breeding and of the 14 species found in the tea bushes, seven species belong to the genus Rarochestes. In both cases roughly $40 \%$ of the species are from the genus, Raorchestes. My results in Munnar are similar to the percentage of direct developers reported Murrieta-Galindo et al. (2013), in coffee plantations in Mexico. The direct developing species, Eleutherodactylus bransfordii, has been reported to be the most common species at La selva in Costa Rica from several studies (Folt and Reider, 2013; Lieberman et al. 1986; Heinen 1992). The endemic anurans with a specialized life history have shifted to use an altered landscape in India. The tea plantations sampled were between 1500 and $2000 \mathrm{~m}$ in elevation and during my study, no visible deformed individuals of any species were encountered. In a recent study, Wordley et al. (2015) recorded seven species of bats in tea plantations, especially close to wooded areas along riparian zones. Though the density of bats is poorer in tea than it is in coffee plantations, it shows that tea plantations with small patches of native forests provide some refuge for volant mammals. The authors recommend maintenance of native trees along streams in these tea plantations landscapes (Wordley et al. 2015). 
These are the types of suggestions that need to reach the management committees of plantations areas. If implemented on recommendation for one group of animals, these suggestions are likely to be beneficial to several other flora and fauna, directly or indirectly.

With several studies showing the presence of amphibians and other vertebrates surviving in tea plantations, it is important to consider the role that these less than perfect habitats play in the long term conservation of species richness (Brockerhoff et al. 2008; Felton et al. 2010; Kumara et al. 2004; Palacios et al. 2013). Ferreira et al. (2015) found 37 species of amphibians in a heterogeneous cacao growing area in south-east Brazil. In some cases, these small populations may act as source populations for the protected areas nearby, or the plantations may themselves act as buffer zones around protected areas to provide barriers to them from additional urban developments (Brockerhoff et al. 2008; Kumara et al. 2004). Whitfiedl et al. (2007) reported that while all common leaf-litter species declined in old-growth forests in a Selva, one frog and two lizards did not decline in an adjacent abandoned cacao plantation, and they argue that thick leaf-litter may have supported these species. While the research community is aware of the conservation roles of plantations, it is key to involve the management staff of plantations in the process of sustainable design and management of plantations (Brockerhoff et al. 2008). Organizations like Rainforest Alliance and Conservation International Foundation have several certifications that can help these industries sell their produce at increased prices to a socially conscious market (Edwards and Laurance 2012). The term 'High Conservation Value' (HCV), initially used in the logging industry is now used to assess areas for 
conversion to plantations, as well as for species of high conservation priority (Edwards and Laurance 2012). However, several managers are unaware of these schemes, and others believe that it is difficult to obtain these certifications (Mudappa and Raman 2012; Shankar and Mudappa 2003). The difficulty is the variation in each plantation type, location, harvesting methods, and the use of different chemicals that make drafting a generalized document for green certification quite challenging and often intimidating for the average plantation owner, as well as for the research community (Brockerhoff et al. 2008; Edwards and Laurance 2012; Gardner et al. 2007). The absence of information on the viable population sizes, and population health of the $\mathrm{HCV}$ species also makes it difficult to justify certifications (Edwards and Laurance 2012). Whatever be the methods, once large plantations in an area are able to get certified, they should be able to encourage and help small private plantation owners get certified as well. Ryan et al. (2002) reported 14, two, and two, species of amphibians, respectively from three different standard methods (drift fences with funnel traps, cover board method and time constrained searches) in different kinds of plantation landscapes (recent clear-cut area, pine plantation, and mixed pine-hardwood forest) from South Carolina. The study showed that drift fences with funnel traps captured more species and individuals of amphibians than the other two methods (Ryan et al. 2002). Thus, it is not just the type of plantation but also the methods used in the study that can affect the diversity results. Most researchers are limited by several constraints, both financial, temporal and logistical and thus each study is very unique in the methods used making the studies difficult to compare (Brockerhoff et al. 2008; Gardner et al. 2007). In some rare cases where old plantations are abandoned, recolonization studies have shown that with time, the 
biodiversity of the area recovers but the rate of recovery can vary drastically depending on the location (Hilje and Aide 2012). Secondary forests in Costa Rica showed original species richness in 10 to 16 years, whereas in Puerto Rico the recovery took one to five years, and in Brazil only $60 \%$ of the original species diversity was recovered after 14 to 19 years (Hilje and Aide 2012). Though the recovery time in some cases may be rather long, and incomplete, it is still important to monitor the rates of recovery and recolonization of species in abandoned plantations to determine their importance for biodiversity because plantation acreage continues to increase.

There has been a continuous increase in the area that is being converted to plantations over the years (FAO 2011; FAO and JRC 2012) and this area is going to keep increasing in light of the United Nation's prediction that the human population will increase to nine billion by the end of this century. The consumption of black tea is modeled to grow at 3\% annually to reach by 4.14 million tons by 2023 (Chang 2015; Gerland et al. 2014). At the end of their review, Felton et al. (2010) conclude that it is not accurate to make conclusions about whether there was higher diversity in plantations or pastures without accounting for several variations which come with each of the studies. Looking at several single studies of diversity and abundances in streamside management zones in pine forests, Jones et al. (2010) suggest that in the long run it is more important to look at fitness coefficients, not just richness of species in plantations, to gauge the actual long term effects of plantations on native fauna. Brockerhoff et al. (2008), presented several suggestions at different landscape scales for improving the presence of biodiversity in plantations. Some of the small scale suggestions included discussions about the 
composition and structure of plantations, prevention of intensive site manipulations in biodiversity rich regions, increasing the intervals between harvesting, and making better local management decisions on thinning of weeds, and burning (Brockerhoff et al. 2008). Large scale suggestions include the placement of different types, sizes, and shapes of plantations in the landscape, placement of plantations around native habitats to function as buffers, as well as making planation's in fragmented landscapes act as stepping stones between forest fragments (Brockerhoff et al. 2008). Wilcove and Koh (2010), recommended bans on converting forests to oil palm plantations, financial incentives for organic practices, fines for undesirable activities, and promotion of alternate, more sustainable methods of the local resources, a few suggestions to reduce growing negative impacts of oil palm plantations in Southeast Asia. Such information can only be obtained if long-term monitoring plans are in place. With several plantations being in biodiversity hotspots in the tropics, we need to address ways of being able to manage these plantations such that the biodiversity on these unique properties can be supported. In an innovative study from Tanzania, Norfolk et al. (2013) found that floral-dependent insects were found in much higher richness and abundance on the path between tea bushes than on the tea bushes themselves, leading them to suggest that plantation managers should encourage the wild plants that grow in-between tea bushes because they do not compete with tea. In a study comparing cultivated land with hedges and cultivated land without hedges, Nopper et al. (2016) found that corn growing land with hedges in Madagascar had three species of reptiles (Astrochelys radiata, Pyxis arachnoides, and Phelsuma breviceps) that were not present in adjoining forested land and were reported in the first three threat categories of the IUCN red list. With access to guidelines before designing plantations, it 
is possible to make these necessary evils as sustainable as possible. The present review shows that it is hard to come up with generalized global suggestions to make plantations sustainable habitats for remnant native flora and fauna. The need of the hour is several local studies in different plantations types, targeting different groups of plants and animals such that the most appropriate long-term suggestions can be implemented in each case.

\section{Acknowledgments}

I thank Florida International University for a graduate assistantship which allowed for data collection. I thank the Wildlife Institute of India, Dehradun, India and Dr.

Karthikeyan Vasudevan for the Research Associate post provided from 2012 to 2015 . I thank the KDHP Private Ltd. for permission to work on the tea plantation property in Munnar, Kerala. I also thank Elangovan for help with field work.

\section{Literature Cited}

Allsopp, M.H., De Lange, W.J. and Veldtman, R., 2008. Valuing insect pollination services with cost of replacement. PLoS One. DOI:org/10.1371/journal.pone.0003128.

Arruda, M.P., Morielle-Versute, E., Silva, A., Schneider, M.P.C. and Goncalves, E.C., 2011. Contemporary gene flow and weak genetic structuring in Rococo Toad (Rhinella schneideri) populations in habitats fragmented by agricultural activities. Amphibia-Reptilia. 32:399-411. 
Becker, C.G., Joner, F. and Fonseca, C.R., 2007. Ecologically-sustainable tree monocultures contribute to conservation of an Araucaria Forest endemic frog. Journal of Natural History. 41:1739-1752.

Brockerhoff, E.G., Jactel, H., Parrotta, J.A., Quine, C.P. and Sayer, J., 2008. Plantation forests and biodiversity: Oxymoron or opportunity? Biodiversity and Conservation. 17:925-951.

Chang, K., 2015. World tea production and trade: Current and future development. Food and Agriculture Organization of the United Nation. Rome.

Crump, M. L., and N. J. Scott. 1994. Visual encounter surveys. W. R. Heyer, M. A. Donnelly, R. W. McDiarmid, L. A. C. Hayek, and M. S. Foster, editors. Measuring and monitoring biological diversity: Standard methods for amphibians. Smithsonian Institution Press, Washington, D.C., USA.

Conservation International Foundation. 2014. Map of global biodiversity hotspots of the world. http://www.conservation.org/How/Pages/Hotspots.aspx.

da Silva, F. R., Rodrigo S. S., Maria A. N., and Denise de Cerqueira Rossa-Feres. 2009. Anuran captured in pitfall traps in three agrosystem in Northwestern São Paulo State, Brazil. Biota Neotropica. 9:253-255.

Daniels, R. J. R. 1991. The Problem of conserving amphibians in the Western Ghats, India. Current Science. 60:630-632.

Daniels, R. J. R. 1992. Geographical Distribution patterns of amphibians in the Western Ghats, India. Journal of Biogeography. 19:521-529.

Daniels, R. J. R. 2003. Impact of tea cultivation on anurans in the Western Ghats. Current Science. 85:1415-1422.

Das, A., Krishnaswamy, J., Bawa, K.S., Kiran, M.C., Srinivas, V., Kumar, N.S. and Karanth, K.U., 2006. Prioritization of conservation areas in the Western Ghats, India. Biological Conservation. 133:16-31.

Deheuvels, O., Rousseau, G.X., Quiroga, G.S., Franco, M.D., Cerda, R., Mendoza, S.J.V. and Somarriba, E., 2014. Biodiversity is affected by changes in management intensity of cocoa-based agroforests. Agroforestry Systems. 88:1081-1099.

Dibner, R. R., Lawton, C. and Marnell, F., 2014. Reproduction of common frogs, Rana temporaria, in a managed conifer forest and bog landscape in Western Ireland. Herpetological Conservation and Biology. 9:38-47. 
Edwards, D.P. and Laurance, S.G., 2012. Green labelling, sustainability and the expansion of tropical agriculture: Critical issues for certification schemes. Biological Conservation. 151:60-64.

FAO. 2005. Global Forest Resources Assessment. Progress towards sustainable forest management. Food and Agriculture Organization of the United Nations. Rome. Forestry Paper. 147.

FAO. 2006. Global planted forests thematic study: Results and analysis, by A. Del Lungo, J. Ball and J. Carle. Planted Forests and Trees Working Paper 38. Rome (also available at www.fao.org/forestry/site/10368/en).

FAO 2009. FAOSTAT online statistical service. Food and Agriculture Organization of the United Nations, Rome, Italy. http://faostat.fao.org/

FAO, 2011. Global Forest Resources Assessment. 2010. www.fao.org, Rome, Italy.

FAO and JRC. 2012. Global forest land-use change 1990-2005, by E.J. Lindquist, R. D'Annunzio, A. Gerrand, K. MacDicken, F. Achard, R. Beuchle, A. Brink, H.D. Eva, P. Mayaux, J. San-Miguel-Ayanz \& H-J. Stibig. FAO Forestry Paper No. 169. Food and Agriculture Organization of the United Nations and European Commission Joint Research Centre. Rome, FAO.

FAO. 2015. Global Forest Resources Assessment 2015. FAO Forestry Paper No. 1. UN Food and Agriculture Organization, Rome.

Felton, A., Knight, E., Wood, J., Zammit, C. and Lindenmayer, D., 2010. A metaanalysis of fauna and flora species richness and abundance in plantations and pasture lands. Biological Conservation. 143:545-554.

Ferreira, T. R. L., R.B., Silva-Soares, T., Mageski, M.M., Pertel, W., Rödder, D., de Barros, E.H. and J. O. Engler. 2015. Anuran community of a cocoa agroecosystem in southeastern Brazil. Salamandra. 51:259-262.

Fogarty, J.H. and Vilella, F.J., 2003. Use of native forest and eucalyptus plantations by Eleutherodactylus frogs. The Journal of wildlife management. 67:186-195.

Folt, B. and Reider, K.E., 2013. Leaf-litter herpetofaunal richness, abundance, and community assembly in mono-dominant plantations and primary forest of northeastern Costa Rica. Biodiversity and Conservation. 22:2057-2070.

Gardner, T.A., Barlow, J. and Peres, C.A., 2007. Paradox, presumption and pitfalls in conservation biology: The importance of habitat change for amphibians and reptiles. Biological Conservation. 138:166-179. 
Gerland, P., Raftery, A.E., Ševčíková, H., Li, N., Gu, D., Spoorenberg, T., Alkema, L., Fosdick, B.K., Chunn, J., Lalic, N. and Bay, G., 2014. World population stabilization unlikely this century. Science. 346:234-237.

Ghazoul, J., 2005. Buzziness as usual? Questioning the global pollination crisis. Trends in Ecology and Evolution. 20: 367-373.

Ghose, S.L., Donnelly, M.A., Kerby, J. and Whitfield, S.M., 2014. Acute toxicity tests and meta-analysis identify gaps in tropical ecotoxicology for amphibians. Environmental Toxicology and Chemistry. 33:2114-2119.

Gurushankara, H.P., Krishnamurthy, S.V. and Vasudev, V., 2007. Morphological abnormalities in natural populations of common frogs inhabiting agro-ecosystems of central Western Ghats. Applied Herpetology. 4:39-45.

Heinen, J.T., 1992. Comparisons of the leaf litter herpetofauna in abandoned cacao plantations and primary rain forest in Costa Rica: Some implications for faunal restoration. Biotropica. 24:431-439.

Hilje, B. and Aide, T.M., 2012. Recovery of amphibian species richness and composition in a chronosequence of secondary forests, northeastern Costa Rica. Biological Conservation. 146:170-176.

Hudson, L.N., Newbold, T., Contu, S., Hill, S.L., Lysenko, I., Palma, A.D., Phillips, H.R., Senior, R.A., Bennett, D.J., Booth, H. and Choimes, A., 2014. The PREDICTS database: A global database of how local terrestrial biodiversity responds to human impacts. Ecology and Evolution. 4:4701-4735.

IIASA, 2002, International Institute for Applied Systems Analysis.

IUCN 2016. The IUCN Red List of Threatened Species. Version 2016-2. $<$ http://www.iucnredlist.org > . Downloaded on 04 September 2016.

Johnson, L.A., Welch, B. and Whitfield, S.M., 2013. Interactive effects of pesticide mixtures, predators, and environmental regimes on the toxicity of two pesticides to red-eyed tree frog larvae. Environmental Toxicology and Chemistry. 32:23792386.

Jones, P.D., Hanberry, B.B. and Demarais, S., 2010. Managing the southern pine forestretained wetland interface for wildlife diversity: Research priorities. Wetlands. 30:381-391. 
Kottawa-Arachchi, J.D., Gamage, R., Jayathilake, G.G. and Hiripitiya, H.S.V. 2014. Importance of different habitats for herpetofauna in tea plantation ecosystem in Mattakelle tea estate, Sri Lanka. Proceedings of the International Symposium on Agriculture and Environment 2014, University of Ruhuna, Sri Lanka. 197-201

Krishna, S.N., Krishna, S.B. and Vijayalaxmi, K.K., 2005. Variation in anuran abundance along the streams of the Western Ghats, India. The Herpetological Journal. 15:167-172.

Kumara, H.N., Kumar, M.A., Sharma, A.K., Sushma, H.S., Singh, M. and Singh, M., 2004. Diversity and management of wild mammals in tea gardens in the rainforest regions of the Western Ghats, India: A case study from a tea estate in the Anaimalai Hills. Current Science. 87:1282-1286.

Laurance, W.F., 2014. Emerging threats to tropical forests. Annals of the Missourri Botanical Garden. 100:159-169.

Lazcano-Barrero, M.A., Gongora-Arones, E. and Vogt, R.C., 1992. Anfibios y reptiles de la Selva Lacandona. Reserva de la Biosfera Montes Azules, Selva Lacandona: Investigación para su conservación. Ecosfera. 1:135-172.

Lieberman, S.S., 1986. Ecology of the leaf litter herpetofauna of a neotropical rain forest: La Selva, Costa Rica. Acta Zool Mexicana. 15:1-72.

Loehle, C., Wigley, T.B., Shipman, P.A., Fox, S.F., Rutzmoser, S., Thill, R.E., Melchiors, M.A., 2005. Herpetofaunal species richness responses to forest landscape structure in Arkansas. Forest Ecology and Management. 209:293-308.

Martínez Baños, V., Pacheco Florez, V. and Ramírez-Pinilla, M.P., 2011. Abundancia relativa y uso de microhábitat de la rana Geobatrachus walkeri (Anura: Strabomantidae) en dos hábitats en Sierra Nevada de Santa Marta, Colombia. Revista de Biología Tropical. 59:907-920.

Mitchell, J.C., Rinehart, S.C., Pagels, J.F., Buhlmann, K.A. and Pague, C.A., 1997. Factors influencing amphibian and small mammal assemblages in central Appalachian forests. Forest Ecology and Management. 96:65-76.

Moguel, P. and Toledo, V.M., 1999. Biodiversity conservation in traditional coffee systems of Mexico. Conservation Biology. 13:11-21.

Mudappa, D. and Raman, T.S., 2012. Beyond the borders: Wildlife conservation in landscapes fragmented by plantation crops in India. NCF Working paper 1, Nature Conservation Foundation, Mysore. 
Murrieta-Galindo, R., González-Romero, A., López-Barrera, F. and Parra-Olea, G., 2013. Coffee agrosystems: an important refuge for amphibians in central Veracruz, Mexico. Agroforestry Systems. 87:767-779.

Myers, N., Mittermeier, R.A., Mittermeier, C.G., Da Fonseca, G.A. and Kent, J., 2000. Biodiversity hotspots for conservation priorities. Nature. 403:853-858.

Nopper, J., Lauströer, B., Rödel, M.O. and Ganzhorn, J.U., 2016. A structurally enriched agricultural landscape maintains high reptile diversity in sub-arid south-western Madagascar. Journal of Applied Ecology. DOI:10.1111/1365-2664.12752.

Norfolk, O., Sadiki, L.L., Broughton, B., Otieno, M. and Nuttman, C., 2013. Tea breaks: How flower visitors can benefit from unplanned floral buffer strips in a Tanzanian tea plantation. African Journal of Ecology. 51:380-384.

Nori, J., Lemes, P., Urbina-Cardona, N., Baldo, D., Lescano, J. and Loyola, R., 2015. Amphibian conservation, land-use changes and protected areas: A global overview. Biological Conservation. 191:367-374.

Oxforddictionaries.com, 2016.

Palacios, C.P., Agüero, B. and Simonetti, J.A., 2013. Agroforestry systems as habitat for herpetofauna: Is there supporting evidence? Agroforestry Systems. 87:517-523.

Piatti, L., Souza, F.L. and Filho, P.L., 2010. Anuran assemblage in a rice field agroecosystem in the Pantanal of central Brazil. Journal of Natural History. $44: 1215-1224$.

Popescu, V.D. and Hunter, M. L. Jr. 2011. Clear-cutting affects habitat connectivity for a forest amphibian by decreasing permeability to juvenile movements. Ecological Applications. 21:1283-1295.

Rathod, S. and Rathod, P., 2013. CEPF Western Ghats Special Series: Amphibian communities in three different coffee plantation regimes in the Western Ghats, India. Journal of Threatened Taxa. 5:4404-4413.

Ryan, T.J., Philippi, T., Leiden, Y.A., Dorcas, M.E., Wigley, T.B. and Gibbons, J.W., 2002. Monitoring herpetofauna in a managed forest landscape: Effects of habitat types and census techniques. Forest Ecology and Management. 167:83-90.

Shah, S.K. and Pate, V.A., 2016. Tea production in India: Challenges and opportunities. Journal of Tea Science Research. 6:1-6.

Shalleck, J. 1972. Tea. New York: Viking Press. 
Shankar, T.R. and Mudappa, D., 2003. Bridging the gap: Sharing responsibility for ecological restoration and wildlife conservation on private lands in the Western Ghats. Social Change. 33:129-141.

Slowinski, J.B., Crother, B.I. and Fauth, J.E., 1987. Diel differences in leaf-litter abundances of several species of reptiles and amphibians in an abandoned cacao grove in Costa Rica. Revista de Biología Tropical/International Journal of Tropical Biology and Conservation. 35:349-350.

Sreekar, R., Purushotham, C.B., Saini, K., Rao, S.N., Pelletier, S. and Chaplod, S., 2013. Photographic capture-recapture sampling for assessing populations of the Indian gliding lizard Draco dussumieri. PloS One.

DOI:org/10.1371/journal.pone.0055935.

Thompson, I.D., Baker, J.A. and Ter-Mikaelian, M., 2003. A review of the long-term effects of post-harvest silviculture on vertebrate wildlife, and predictive models, with an emphasis on boreal forests in Ontario, Canada. Forest Ecology and Management. 177:441-469.

Thompson, M.E., Nowakowski, A.J. and Donnelly, M.A., 2015. The importance of defining focal assemblages when evaluating amphibian and reptile responses to land use. Conservation Biology. 30:249-258.

Vonesh, J.R., 2001. Patterns of richness and abundance in a tropical African leaf-litter herpetofauna. Biotropica. 33:502-510.

Waldick, R.C., Freedman, B. and Wassersug, R.J., 1999. The consequences for amphibians of the conversion of natural, mixed-species forests to conifer plantations in southern New Brunswick. Canadian Field-Naturalist. 113:408-418.

Weather-and-climate.com. https://weather-and-climate.com/average-monthly-RainfallTemperature-Sunshine-in-India.

Winfree, R., Gross, B.J. and Kremen, C., 2011. Valuing pollination services to agriculture. Ecological Economics. 71:80-88.

Wijeratne, M.A., Anandacoomaraswamy, A., Amarathunga, M.K.S.L.D., Ratnasiri, J., Basnayake, B.R.S.B. and Kalra, N., 2011. Assessment of impact of climate change on productivity of tea (Camellia sinensis L.) plantations in Sri Lanka. Journal of the National Science Foundation of Sri Lanka. 35:119-126.

Wilcove, D.S. and Koh, L.P., 2010. Addressing the threats to biodiversity from oil-palm agriculture. Biodiversity and Conservation. 19:999-1007. 
Wordley, C.F., Sankaran, M., Mudappa, D. and Altringham, J.D., 2015. Landscape scale habitat suitability modelling of bats in the Western Ghats of India: Bats like something in their tea. Biological Conservation. 191:529-536. 


\section{Tables}

\begin{tabular}{|c|c|c|c|c|c|}
\hline \multirow{3}{*}{ Region and subregions } & \multicolumn{5}{|c|}{ Total plantation forests ${ }^{3}$} \\
\hline & \multicolumn{3}{|l|}{ Area } & \multicolumn{2}{|l|}{ Change \% } \\
\hline & 1990 & 2000 & 2005 & $1990-2000$ & $2000-2005$ \\
\hline Africa & 12245 & 12865 & 13338 & 0.5 & 0.7 \\
\hline Asia & 46591 & 55665 & 64888 & 1.8 & 3.1 \\
\hline Europe & 22530 & 26588 & 27694 & 1.7 & 0.8 \\
\hline North and Central America & 10782 & 17937 & 18844 & 5.2 & 1.0 \\
\hline Oceania & 2447 & 3491 & 3865 & 3.6 & 2.1 \\
\hline South America & 9132 & 11437 & 12189 & 2.3 & 1.3 \\
\hline World & 103728 & 127984 & 140818 & 2.1 & 1.9 \\
\hline
\end{tabular}

Table 1.1. Global area of plantation forests based on 1000 acres (FAO 2005) 


\begin{tabular}{|c|c|c|c|c|}
\hline \multicolumn{5}{|c|}{$\operatorname{glm}($ formula $=\mathrm{SP} \sim$ Harvest $+\mathrm{SF}+\mathrm{Age}+\mathrm{BH}$, family $=$ poisson $(\log ))$} \\
\hline Coefficients & \multicolumn{2}{|c|}{ Number of Fisher Scoring iterations: 5} \\
\hline & Estimate & Std. Error & $\mathrm{Z}$ value & $\operatorname{Pr}(>|\mathrm{z}|)$ \\
\hline (Intercept) & 1.4837861 & 0.1695084 & 8.753 & $<2 \mathrm{e}-16^{* * *}$ \\
\hline Harvest[T.Periodic] & 0.3287687 & 0.1162714 & 2.828 & $0.00469^{* *}$ \\
\hline SF & 0.031625 & 0.0032394 & 9.763 & $<2 \mathrm{e}-16^{* * *}$ \\
\hline Age & 0.0002845 & 0.001343 & 0.212 & 0.83223 \\
\hline BH[T.Y] & -0.0048103 & 0.121556 & -0.04 & 0.96843 \\
\hline
\end{tabular}

Table 1.2. Generalized Linear Model (GLM) for the number of species in plantations (SP) being described by the type of harvest (Periodic), number of species in the control forest (SF), age of plantation, and whether the plantation in present in a Biodiversity hotspot $(\mathrm{BH})$ or not. 


\begin{tabular}{|c|c|c|c|c|c|c|}
\hline Sno & IUCN Category & Endemic & Name & Eucalyptus & Shola & Tea \\
\hline 1 & Critically Endangered & $\mathrm{Y}$ & Raorchestes chlorosomma & + & + & - \\
\hline 2 & Critically Endangered & $\mathrm{Y}$ & Raorchestes munnarensis & - & + & + \\
\hline 3 & Critically Endangered & $\mathrm{Y}$ & Raorchestes griet & + & + & + \\
\hline 4 & Critically Endangered & $\mathrm{Y}$ & Rhacophorus pseudomalabaricus & + & - & + \\
\hline 5 & Critically Endangered & $\mathrm{Y}$ & Raorchestes sushili & - & + & - \\
\hline 6 & Endangered & $\mathrm{Y}$ & Rhacophorus calcadensis & + & - & + \\
\hline 7 & Endangered & $\mathrm{Y}$ & Indirana $\mathrm{sp}$ & + & + & - \\
\hline 8 & Vulnerable & $\mathrm{Y}$ & Raorchestes dubois & + & + & + \\
\hline 9 & Vulnerable & $\mathrm{Y}$ & Duttaphrynus microtympanum & + & - & + \\
\hline 10 & Near Threatened & $\mathrm{Y}$ & Duttaphrynus parietalis & + & - & + \\
\hline 11 & Near Threatened & $\mathrm{Y}$ & Raorchestes beddomii & + & + & + \\
\hline 12 & Near Threatened & Y & Raorchestes theuerkaufi & - & + & + \\
\hline 13 & Near Threatened & $\mathrm{Y}$ & Micrixalus sp1 & - & + & - \\
\hline 14 & Near Threatened & Y & Micrixalus sp2 & - & + & - \\
\hline 15 & Near Threatened & $\mathrm{Y}$ & Uperodon species (cfmontana) & - & + & + \\
\hline 16 & Least Concern & $\mathrm{N}$ & Duttaphrynus melanostictus & + & + & + \\
\hline 17 & Data Deficient & $\mathrm{Y}$ & Fejervarya sp & + & + & + \\
\hline 18 & Data Deficient & $\mathrm{Y}$ & Ghatixalus asterops & - & + & + \\
\hline 19 & Not Evaluated & $\mathrm{Y}$ & Raorchestes uthamani & - & + & - \\
\hline 20 & Not Evaluated & $\mathrm{Y}$ & Raorchestes jayarami & + & - & + \\
\hline 21 & Not Evaluated & $\mathrm{Y}$ & Raorchestes kadalarensis & + & + & + \\
\hline 22 & Not Evaluated & $\mathrm{Y}$ & Nyctybatrachus poocha & - & + & + \\
\hline 23 & Not Evaluated & $\mathrm{Y}$ & Nyctibatrachus acanthodermis & + & - & - \\
\hline 24 & Not Evaluated & $\mathrm{Y}$ & Beddomixalus bijui & - & - & + \\
\hline \multirow[t]{2}{*}{25} & Not Evaluated & $\mathrm{Y}$ & Ghatixalus magnus & - & + & - \\
\hline & Totals & All except 1 & & 14 & 18 & 17 \\
\hline
\end{tabular}

Table. 1.3. Checklist of amphibians recorded in different habitats (eucalyptus, sholas, and tea) in tea plantations in Munnar, Kerala, India according to the IUCN threat status (Endemic to Western Ghats; Y-yes, N-no; IUCN 2016). 


\section{Figures}

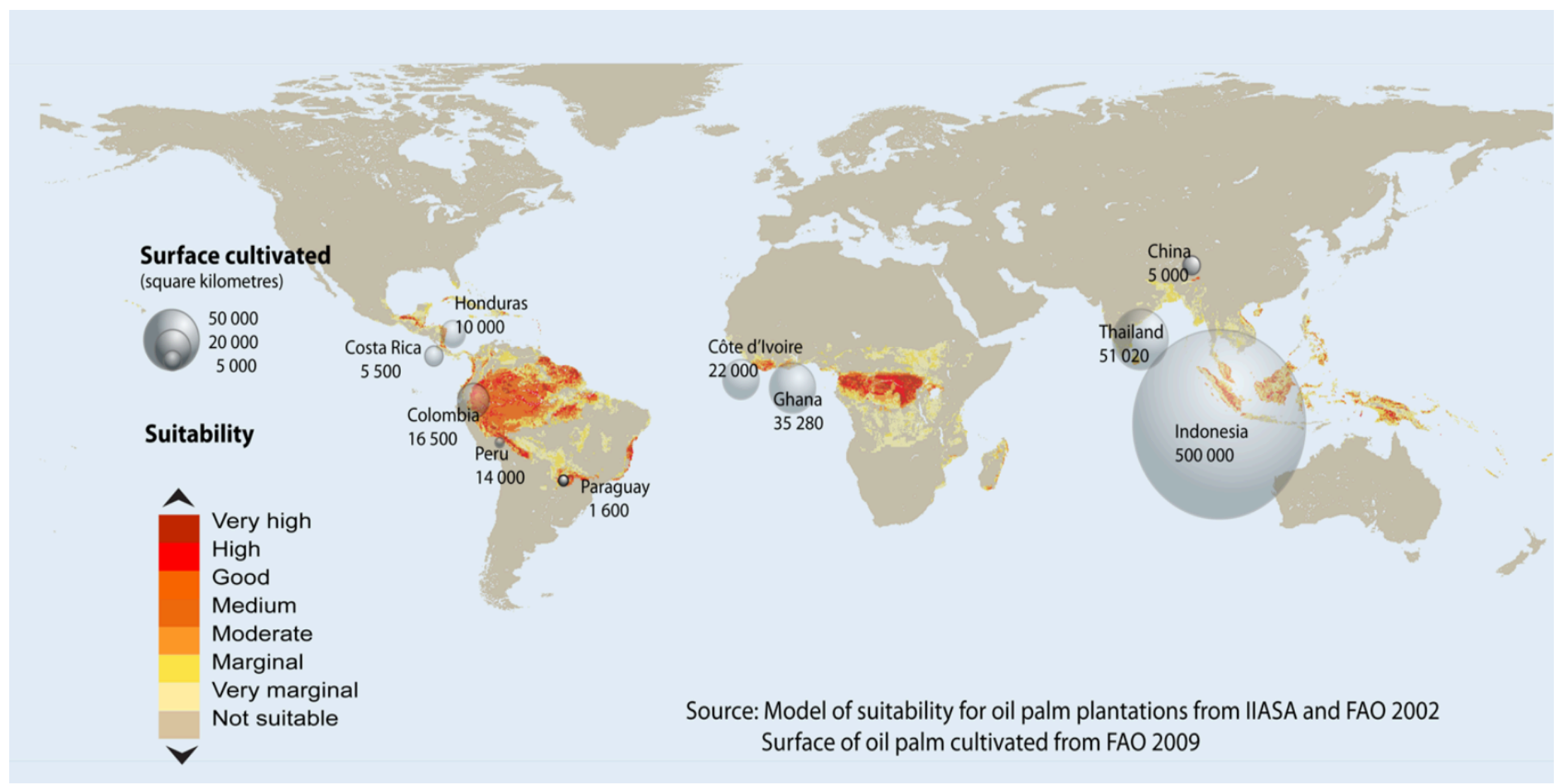

Figure 1.1. Land suitable for palm oil plantations (IIASA, 2002; FAO 2009) 


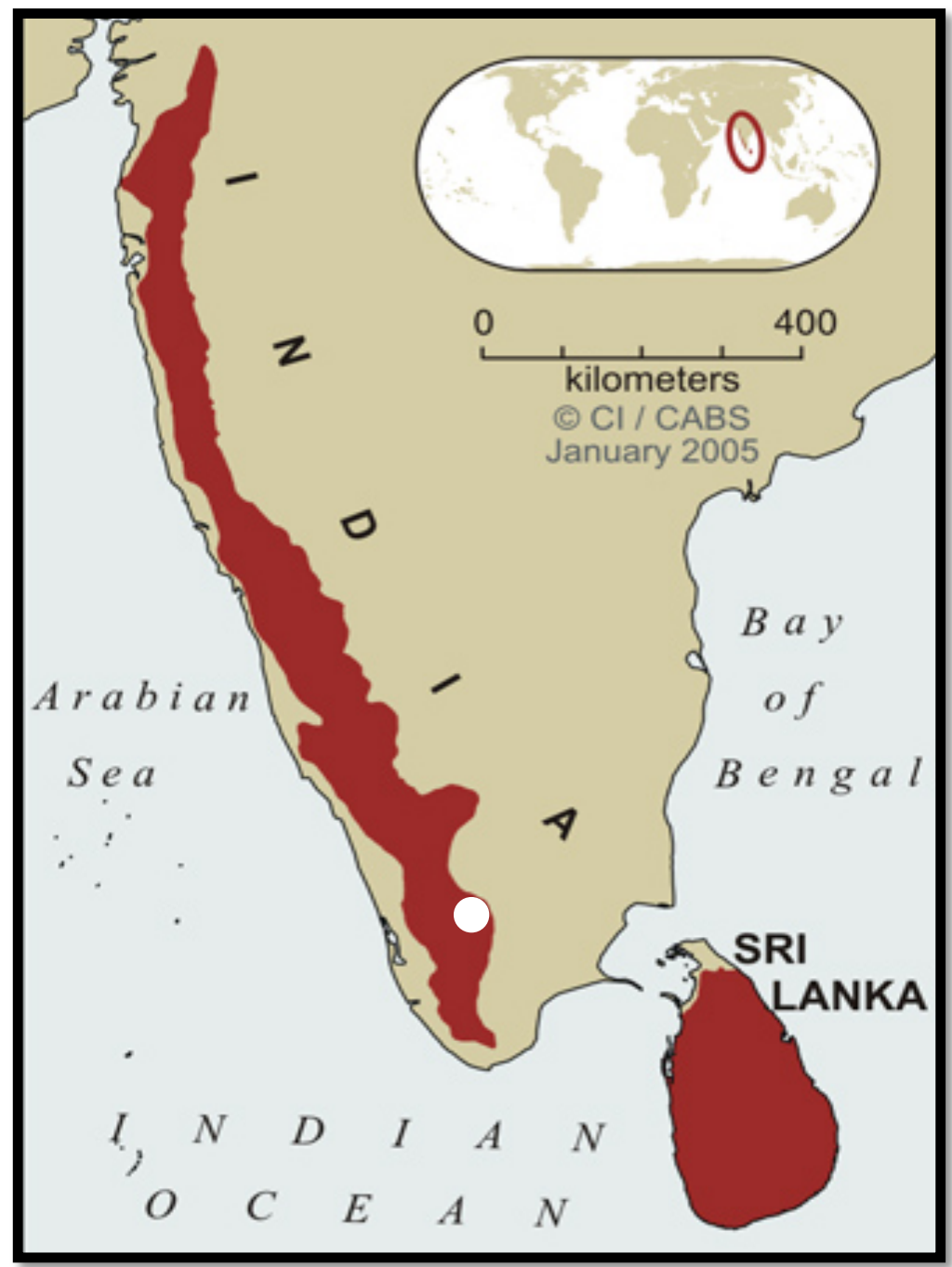

Figure 1.2. Location of field site (white dot) within the Western Ghats and Sri Lanka Biodiversity hotspot in, Munnar, Kerala. (Map from IUCN, 2016) 


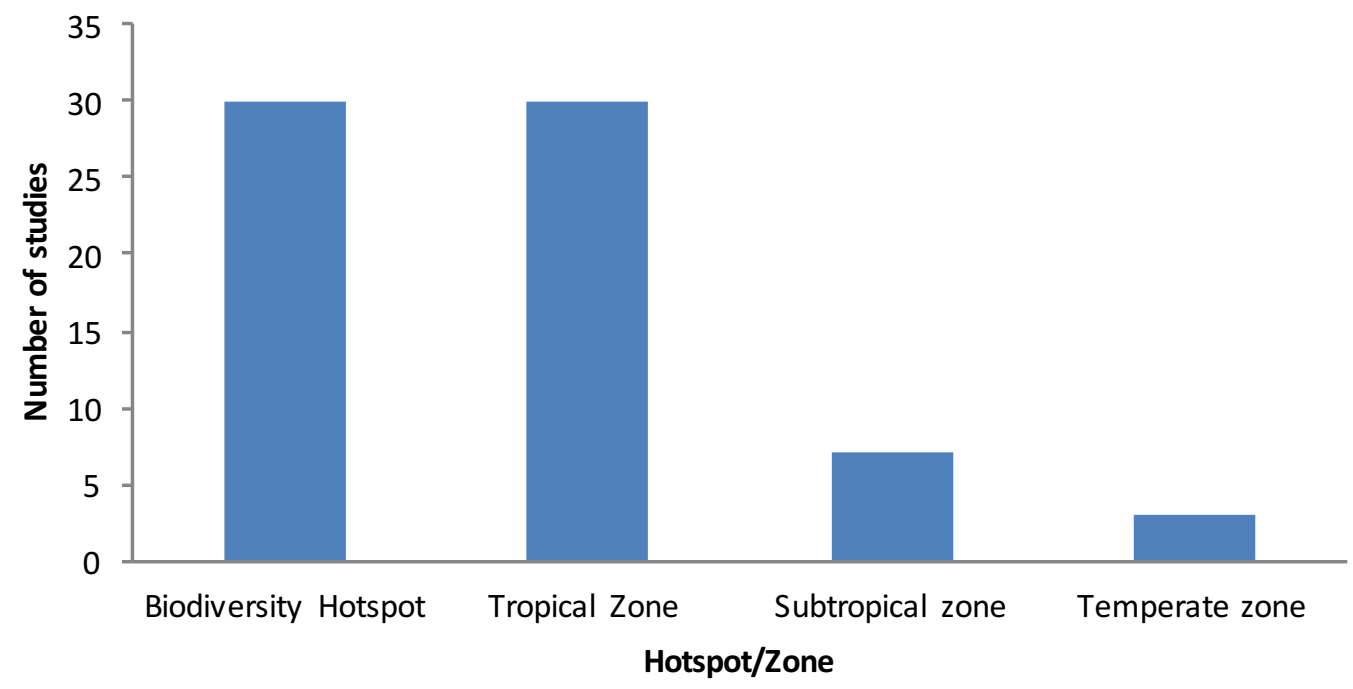

Figure 1.3. Number of studies in each latitudinal zone. 


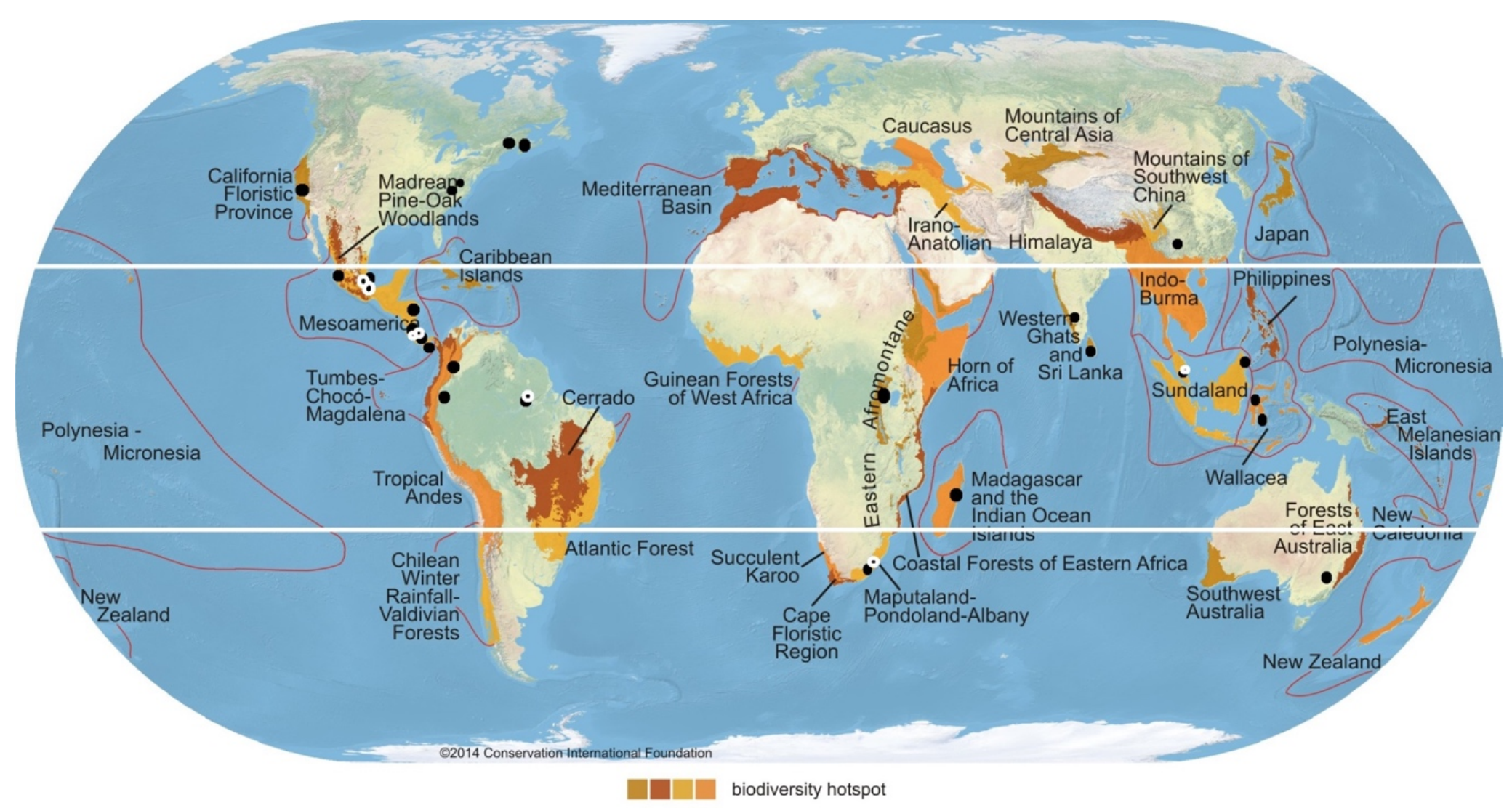

Conservation International (conservation.org) defines 35 biodiversity hotspots - extraordinary places that harbor vast numbers of plant and animal species found nowhere else. All are heavily threatened by habitat loss and degradation, making their conservation crucial to protecting nature for the benefit of all life on Earth.

Figure 1.4. Location of all the 40 study sites (Conservation International Foundation, 2014). 


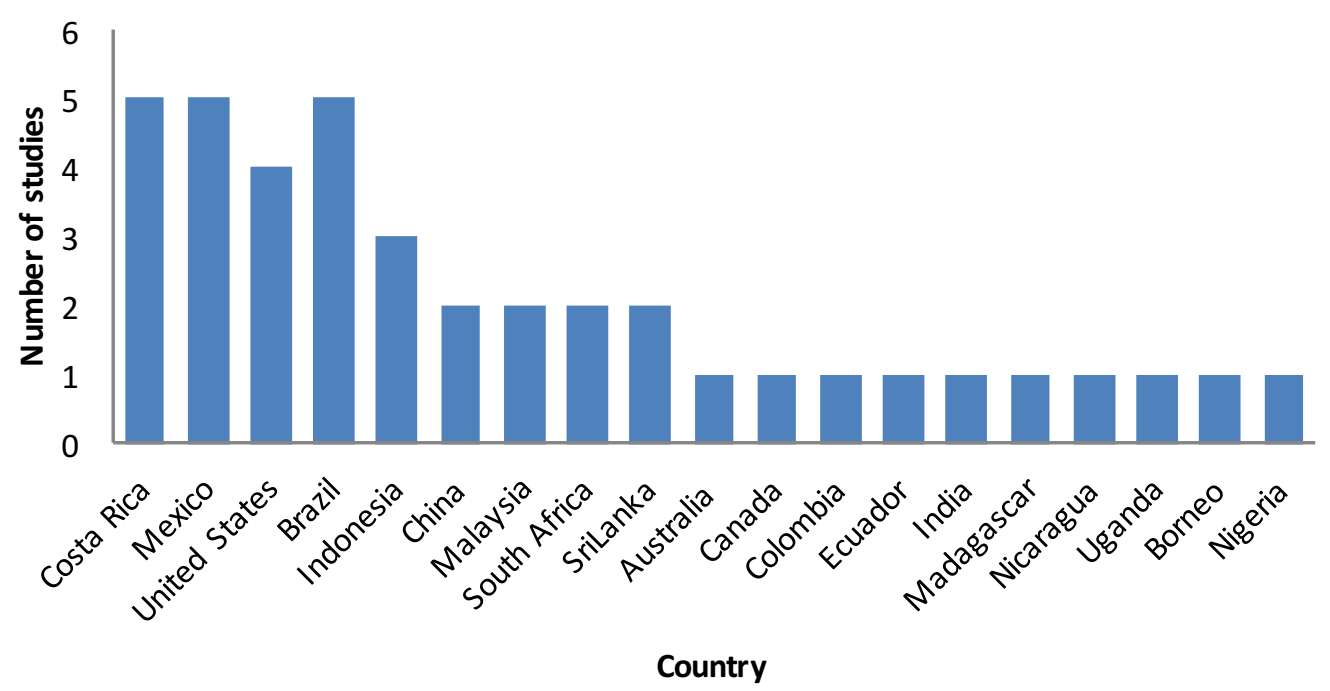

Figure 1.5. Number of studies in different countries of the world $(\mathrm{N}=40)$. 


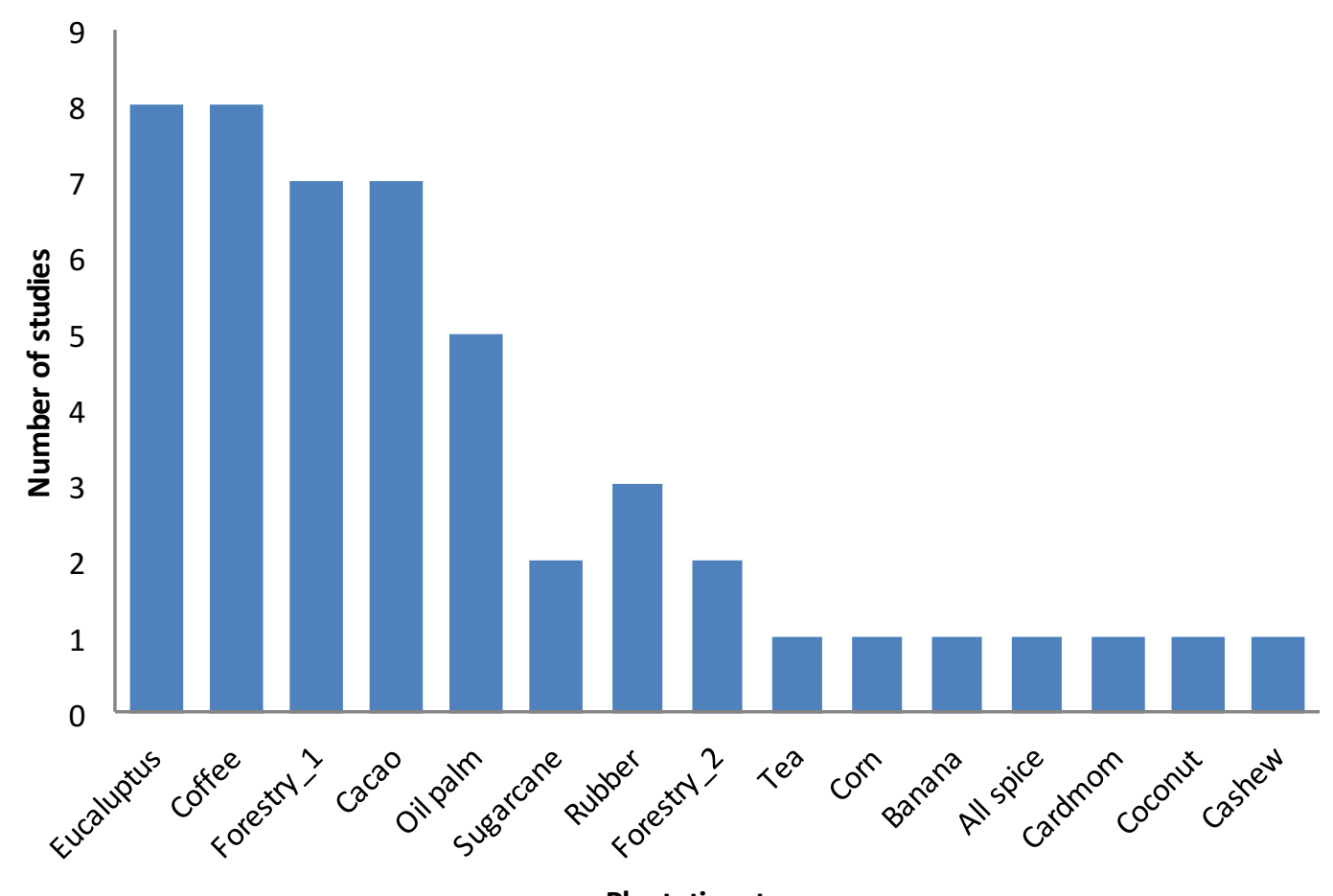

Plantation types

Figure 1.6. Types of plantations with comparisons of amphibians between plantations and primary forests. 


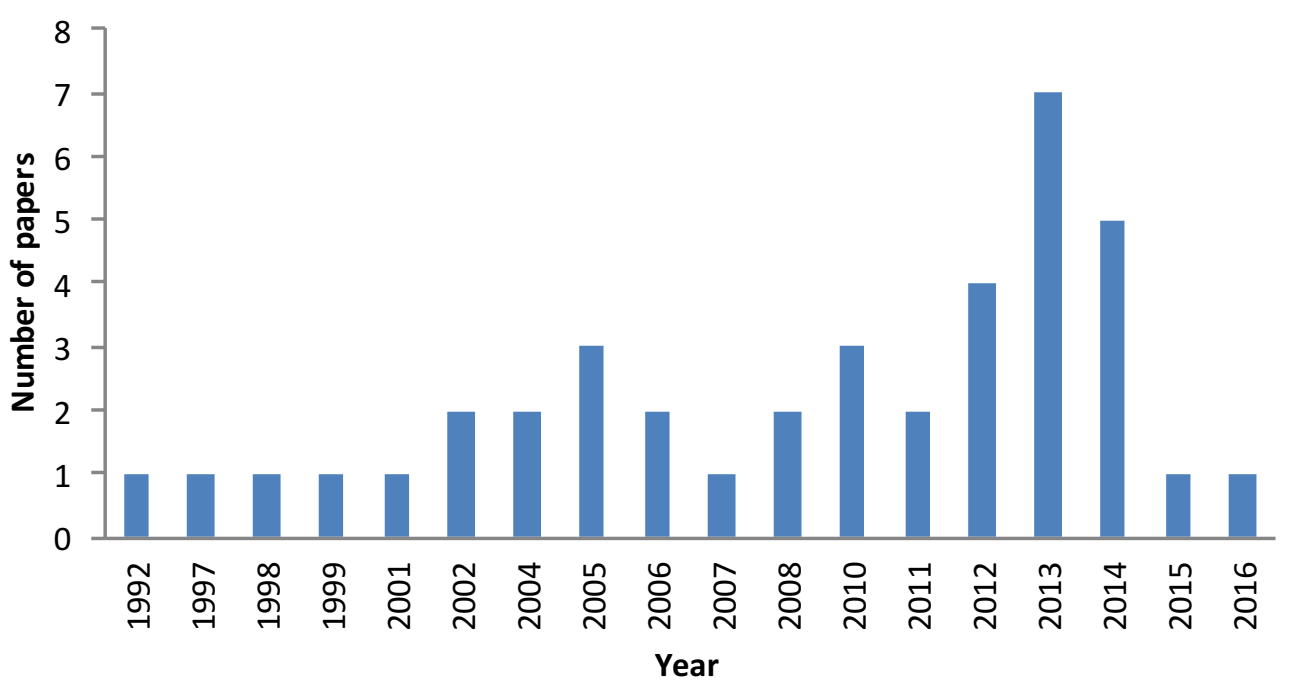

Figure 1.7. Number of papers published by year. 


\section{Appendices}

Appendix 1.1. Forty papers used for the review in chapter 1.

Behm, J.E., Yang, X. and Chen, J., 2013. Slipping through the cracks: rubber plantation is unsuitable breeding habitat for frogs in Xishuangbanna, China. PloS One. DOI:org/10.1371/journal.pone.0073688.

Beirne, C., Burdekin, O. and Whitworth, A., 2013. Herpetofaunal responses to anthropogenic habitat change within a small forest reserve in Eastern Ecuador. The Herpetological Journal. 23:209-209.

Camurugi, F., Lima, T.M., Mercês, E.D.A. and Juncá, F.A., 2010. Anurans of the Reserva Ecológica da Michelin, municipality of Igrapiúna, state of Bahia, Brazil. Biota Neotropica. 10:305-312.

Deheuvels, O., Rousseau, G.X., Quiroga, G.S., Franco, M.D., Cerda, R., Mendoza, S.J.V. and Somarriba, E., 2014. Biodiversity is affected by changes in management intensity of cocoa-based agroforests. Agroforestry Systems. 88:1081-1099.

Demaynadier, P.G. and Hunter, M.L., 1998. Effects of silvicultural edges on the distribution and abundance of amphibians in Maine. Conservation Biology. 12:340-352.

Faria, D., Paciencia, M.L.B., Dixo, M., Laps, R.R. and Baumgarten, J., 2007. Ferns, frogs, lizards, birds and bats in forest fragments and shade cacao plantations in two contrasting landscapes in the Atlantic forest, Brazil. Biodiversity and Conservation. 16: 2335-2357.

Faruk, A., Belabut, D., Ahmad, N., Knell, R.J. and Garner, T.W., 2013. Effects of oilpalm plantations on diversity of tropical anurans. Conservation Biology. 27:615624.

Folt, B. and Reider, K.E., 2013. Leaf-litter herpetofaunal richness, abundance, and community assembly in mono-dominant plantations and primary forest of northeastern Costa Rica. Biodiversity and Conservation. 22:2057-2070.

Gardner, T.A., Ribeiro-Júnior, M.A., Barlow, J.O.S., Ávila-Pires, T.C.S., Hoogmoed, M.S. and Peres, C.A., 2007. The value of primary, secondary, and plantation forests for a Neotropical herpetofauna. Conservation Biology. 21:775-787. 
Gillespie, G., Howard, S., Lockie, D. and Scroggie, M., 2005. Herpetofaunal richness and community structure of offshore islands of Sulawesi, Indonesia. Biotropica. 37:279-290.

Gillespie, G.R., Ahmad, E., Elahan, B., Evans, A., Ancrenaz, M., Goossens, B. and Scroggie, M.P., 2012. Conservation of amphibians in Borneo: Relative value of secondary tropical forest and non-forest habitats. Biological Conservation. 152:136-144.

Gilroy, J.J., Prescott, G.W., Cardenas, J.S., Castañeda, P.G.D.P., Sánchez, A., RojasMurcia, L.E., Medina Uribe, C.A., Haugaasen, T. and Edwards, D.P., 2014. Minimizing the biodiversity impact of Neotropical oil palm development. Global Change Biology. 21:1531-1540.

Heinen, J.T., 1992. Comparisons of the leaf litter herpetofauna in abandoned cacao plantations and primary rain forest in Costa Rica: Some implications for faunal restoration. Biotropica. 24:431-439.

Homyack, J.A., Aardweg, Z., Gorman, T.A. and Chalcraft, D.R., 2013. Initial effects of woody biomass removal and intercropping of switchgrass (Panicum virgatum) on herpetofauna in eastern North Carolina. Wildlife Society Bulletin. 37:327-335.

King, D. I., M. D. Hernandez-Mayorga, R. Trubey, R. Raudales, and J. H. Rappole. 2006. An evaluation of the contribution of cultivated allspice (Pimenta dioca) to vertebrate biodiversity conservation in Nicaragua. Biodiversity and Conservation. 16:1299-1320.

Konopik, O., Steffan-Dewenter, I. and Grafe, T.U., 2015. Effects of logging and oil palm expansion on stream frog communities in Borneo, Southeast Asia. Biotropica. 47:636-643.

Krishna, S.N., Krishna, S.B. and Vijayalaxmi, K.K., 2005. Variation in anuran abundance along the streams of the Western Ghats, India. The Herpetological Journal. 15:167-172.

Kudavidanage, E.P., Wanger, T.C., Alwis, C., Sanjeewa, S. and Kotagama, S.W., 2012. Amphibian and butterfly diversity across a tropical land-use gradient in Sri Lanka; implications for conservation decision making. Animal Conservation. 15:253-265.

Louzada, J., Gardner, T., Peres, C. and Barlow, J., 2010. A multi-taxa assessment of nestedness patterns across a multiple-use Amazonian forest landscape. Biological Conservation. 143:1102-1109. 
Mendenhall, C.D., Frishkoff, L.O., Santos-Barrera, G., Pacheco, J., Mesfun, E., Quijano, F.M., Ehrlich, P.R., Ceballos, G., Daily, G.C. and Pringle, R.M., 2014. Countryside biogeography of Neotropical reptiles and amphibians. Ecology. 95:856-870.

Mitchell, J.C., Rinehart, S.C., Pagels, J.F., Buhlmann, K.A. and Pague, C.A., 1997. Factors influencing amphibian and small mammal assemblages in central Appalachian forests. Forest Ecology and Management. 96:65-76.

Murrieta-Galindo, R., López-Barrera, F., González-Romero, A. and Parra-Olea, G., 2013. Matrix and habitat quality in a montane cloud-forest landscape: Amphibians in coffee plantations in central Veracruz, Mexico. Wildlife Research. 40:25-35.

Murrieta-Galindo, R., González-Romero, A., López-Barrera, F. and Parra-Olea, G., 2013. Coffee agrosystems: an important refuge for amphibians in central Veracruz, Mexico. Agroforestry Systems. 87:767-779.

Norhayati, A., Ehwan, N. and Okuda, T., 2014. Assessment of riparian ecosystem on amphibians along a green corridor in oil palm plantation, Pasoh, Negeri Sembilan, Peninsular Malaysia. Sains Malaysiana. 43:655-666.

Onadeko, A.B., 2016. Effect of cocoa (Theobroma cacao) plantation types on the distribution of anuran communities in Ore, Ondo State, Nigeria. Journal of Applied Sciences and Environmental Management. 20:13-22.

Parris, K.M. and Lindenmayer, D.B., 2004. Evidence that creation of a Pinus radiata plantation in south-eastern Australia has reduced habitat for frogs. Acta Oecologica. 25:93-101.

Pethiyagoda Jr, R.S. and Manamendra-Arachchi, K., 2012. Endangered anurans in a novel forest in the highlands of Sri Lanka. Wildlife Research. 39:641-648.

Pineda, E. and Halffter, G., 2004. Species diversity and habitat fragmentation: Frogs in a tropical montane landscape in Mexico. Biological Conservation. 117:499-508.

Pineda, E., Moreno, C., Escobar, F. and Halffter, G., 2005. Frog, bat, and dung beetle diversity in the cloud forest and coffee agro-ecosystems of Veracruz, Mexico. Conservation Biology. 19:400-410.

Ribeiro-Júnior, M.A., Gardner, T.A. and Ávila-Pires, T.C., 2008. Evaluating the effectiveness of herpetofaunal sampling techniques across a gradient of habitat change in a tropical forest landscape. Journal of Herpetology. 42:733-749. 
Russell, C. and Downs, C.T., 2012. Effect of land use on anuran species composition in north-eastern KwaZulu-Natal, South Africa. Applied Geography. 35:247-256.

Santos-Barrera, G. and Urbina-Cardona, J.N., 2011. The role of the matrix-edge dynamics of amphibian conservation in tropical montane fragmented landscapes. Revista Mexicana de Biodiversidad. 82:679-687.

Santos-Barrera, G., Pacheco, J., Mendoza-Quijano, F., Bolaños, F., Cháves, G., Daily, G.C., Ehrlich, P.R. and Ceballos, G., 2008. Diversity, natural history and conservation of amphibians and reptiles from the San Vito Region, southwestern Costa Rica. Revista de Biología Tropical. 56:755-778.

Sax, D.F., 2002. Equal diversity in disparate species assemblages: A comparison of native and exotic woodlands in California. Global Ecology and Biogeography. 11:49-57.

Sung, Y.H., Karraker, N.E. and Hau, B.C., 2012. Terrestrial herpetofaunal assemblages in secondary forests and exotic Lophostemon confertus plantations in South China. Forest Ecology and Management. 270:71-77.

Trimble, M.J. and Aarde, R.J., 2014. Amphibian and reptile communities and functional groups over a land-use gradient in a coastal tropical forest landscape of high richness and endemicity. Animal Conservation. 17:441-453.

Vallan, D., 2002. Effects of anthropogenic environmental changes on amphibian diversity in the rain forests of eastern Madagascar. Journal of Tropical Ecology. 18:725742.

Vonesh, J.R., 2001. Patterns of richness and abundance in a tropical African leaf-litter herpetofauna. Biotropica. 33:502-510.

Waldick, R.C., Freedman, B. and Wassersug, R.J., 1999. The consequences for amphibians of the conversion of natural, mixed-species forests to conifer plantations in southern New Brunswick. Canadian Field-Naturalist. 113:408-418.

Wanger, T.C., Iskandar, D.T., Motzke, I., Brook, B.W., Sodhi, N.S., Clough, Y. and Tscharntke, T., 2010. Effects of land-use change on community composition of tropical amphibians and reptiles in Sulawesi, Indonesia. Conservation Biology. 24:795-802. 
Appendix 1.2. Information from 40 studies used for the review in chapter 1 (Y:Yes; N: No; S_P: Number of species in dominant plantation; S_F: Number of species in forest).

\begin{tabular}{|c|c|c|c|c|c|c|c|c|c|c|}
\hline Sno & Publication_Yea & Initial_clearing_age & Age & Planatation_type & Country & Biodiversityhotspot & Harvesting & S_P & S_F & Difference \\
\hline 1 & 2014 & 1980 & 34 & Oil_palm & Colombia & $\mathrm{Y}$ & Complete & 9 & 9 & 0 \\
\hline 2 & 2014 & 1950 & 64 & Cacao & Costa Rica & $\mathrm{Y}$ & Complete & 11 & 13 & 2 \\
\hline 3 & 2014 & 1990 & 24 & Eucalyptus, Sugar Cane & South Africa & $\mathrm{N}$ & Complete & 6 & 23 & 17 \\
\hline 4 & 2014 & 1970 & 44 & Oil_palm & Malaysia & $\mathrm{Y}$ & Complete & 4 & 6 & 2 \\
\hline 5 & 2014 & 1950 & 64 & Coffee & Costa Rica & $\mathrm{Y}$ & Complete & 5 & 22 & 17 \\
\hline 6 & 2013 & 2000 & 13 & Cacao & Ecuador & $\mathrm{Y}$ & Complete & 4 & 14 & 10 \\
\hline 7 & 2013 & 1970 & 43 & Rubber & China & $\mathrm{N}$ & Complete & 2 & 5 & 3 \\
\hline 8 & 2013 & 1980 & 33 & $\begin{array}{c}\text { Pentaclethra } \\
\text { macroloba, Virola } \\
\text { koschnyi, Vochysia } \\
\text { guatemalensis }\end{array}$ & Costa Rica & $\mathrm{Y}$ & Complete & 31 & 66 & 35 \\
\hline 9 & 2013 & 1890 & 123 & Coffee & Mexico & $\mathrm{Y}$ & Complete & 4 & 4 & 0 \\
\hline 10 & 2013 & 1970 & 43 & Oil_palm & Malaysia & $\mathrm{Y}$ & Complete & 12 & 9 & -3 \\
\hline 11 & 2013 & 1974 & 39 & Pine & Unitea & $\mathrm{N}$ & Complete & 7 & 6 & -1 \\
\hline 12 & 2013 & 1890 & 123 & Coffee & Mexico & $\mathrm{Y}$ & Complete & 7 & 8 & 1 \\
\hline 13 & 2012 & 1960 & 52 & Eucalyptus, Sugar Cane & South Africa & $\mathrm{Y}$ & Complete & 10 & 8 & -2 \\
\hline 14 & 2012 & 1960 & 52 & Oil_palm & Indonesia & $\mathrm{Y}$ & Periodic & 0 & 0 & 0 \\
\hline 15 & 2011 & 1970 & 41 & Pine & SriLanka & $\mathrm{Y}$ & Periodic & 7 & 11 & 4 \\
\hline 16 & 2012 & 1950 & 62 & $\begin{array}{l}\text { Lophostemon } \\
\text { confertus (Brisbane } \\
\text { box) }\end{array}$ & China & $\mathrm{Y}$ & Periodic & 4 & 9 & 5 \\
\hline 17 & 2012 & 1890 & 122 & Eucalyptus, Tea & SriLanka & $\mathrm{Y}$ & Periodic & 17 & 12 & -5 \\
\hline 18 & 2011 & 1960 & 51 & Coffee, Corn & Mexico & $\mathrm{Y}$ & Periodic & 14 & 36 & 22 \\
\hline 19 & 2010 & 1990 & 20 & Cacao & Indonesia & $\mathrm{Y}$ & Periodic & 11 & 18 & 7 \\
\hline 20 & 2010 & 1970 & 40 & Eucalyptus & Brazil & $\mathrm{N}$ & Periodic & 7 & 8 & 1 \\
\hline 21 & 2008 & 1970 & 38 & Eucalyptus & Brazil & $\mathrm{N}$ & Periodic & 13 & 17 & 4 \\
\hline 22 & 2008 & 1970 & 38 & Coffee & Costa Rica & $\mathrm{Y}$ & Periodic & 22 & 22 & 0 \\
\hline 23 & 2006 & 1960 & 46 & Eucalyptus & Brazil & $\mathrm{N}$ & Periodic & 13 & 17 & 4 \\
\hline 24 & 2006 & 1999 & 7 & Allspice & Nicaragua & $\mathrm{Y}$ & Periodic & 17 & 29 & 12 \\
\hline 25 & 2005 & 1850 & 155 & Coffee, Cardamom & India & $\mathrm{Y}$ & Periodic & 1 & 17 & 16 \\
\hline 26 & 2005 & 1970 & 35 & Coconut, Cacao, & Indonesia & $\mathrm{Y}$ & Periodic & 7 & 12 & 5 \\
\hline 27 & 2004 & 1950 & 54 & Coffee & Mexico & $\mathrm{Y}$ & Periodic & 2 & 6 & 4 \\
\hline 28 & 2004 & 1932 & 72 & Pine & Australia & $\mathrm{Y}$ & Periodic & 2 & 7 & 5 \\
\hline 29 & 2002 & 1850 & 152 & Eucalyptus, Rice & Madagascar & $\mathrm{Y}$ & Periodic & 14 & 15 & 1 \\
\hline 30 & 2002 & 1910 & 92 & Eucalyptus & Unitea & $\mathrm{Y}$ & Periodic & 5 & 22 & 17 \\
\hline 31 & 2001 & 1967 & 34 & Pine & Uganda & $\mathrm{Y}$ & Periodic & 15 & 15 & 0 \\
\hline 32 & 1999 & 1970 & 29 & Black Spruce & Canada & $\mathrm{N}$ & Periodic & 6 & 8 & 2 \\
\hline 33 & 1998 & 1970 & 28 & Conifer & Unitea & $\mathrm{N}$ & Periodic & 6 & 10 & 4 \\
\hline 34 & 1997 & 1940 & 57 & Pine & United & $\mathrm{N}$ & Periodic & 13 & 21 & 8 \\
\hline 35 & 1992 & 1950 & 42 & Cacao & Costa Rica & $\mathrm{Y}$ & Periodic & 16 & 19 & 3 \\
\hline 36 & 2015 & 2000 & 15 & Oil palm & Borneo & $\mathrm{Y}$ & Periodic & 11 & 19 & 8 \\
\hline 37 & 2007 & 1950 & 57 & Cacao & Brazil & $\mathrm{Y}$ & Periodic & 14 & 17 & 3 \\
\hline 38 & 2016 & 1887 & 129 & Cacao & Nigeria & $\mathrm{N}$ & Periodic & 19 & 26 & 7 \\
\hline 39 & 2005 & 1880 & 125 & Coffee & Mexico & $\mathrm{Y}$ & Periodic & 13 & 16 & 3 \\
\hline 40 & 2010 & 1950 & 60 & Rubber & Brazil & $\mathrm{Y}$ & Periodic & 26 & 39 & 13 \\
\hline
\end{tabular}




\title{
III. CHAPTER 2
}

A Comparative Study of Standard Methods for Surveying Anurans in Tea Plantations in the Southern Western Ghats

\begin{abstract}
Global amphibian declines have been reported since the late 1980s and some major drivers of these declines are reported to be habitat loss and the emergence of chytridiomycosis caused by the fungus Batrachochytrium dendrobatidis. While amphibian species face declines globally, several new species of amphibians are being described in many parts of the world, especially in Asia. The Western Ghats and Sri Lanka Biodiversity Hotspot is a zone of high endemicity for amphibians, but is also a region that is affected by increasing human population pressures as forestlands are being converted to agricultural areas. Here, I test the efficiency of standard methods of surveying amphibians in active tea plantations in the Indian state of Kerala. Visual encounter surveys, stream transects, and drift fences with funnel traps were tested in three main habitats, tea fields, sholas (remnant forest patches), and eucalyptus forests. A total of 407 individual frogs from 17 species (plus one category for unidentifiable Raorchestes juveniles) were encountered from June to November, 2012. Drift fences with funnel traps were discarded after we had four captures from two species after 2016 trap hours (84 trap nights). Stream transects in shola habitats gave the highest species per person effort, followed by Visual Encounter Surveys in eucalyptus patches. The greatest number of individuals per person-effort were obtained in the shola habitat. We recommend a
\end{abstract}


combination of nocturnal Visual Encounter Surveys and Stream surveys to sample for anurans in the tea plantation landscape of the Southern Western Ghats, India.

Key words: Amphibians, Standard methods, Tea plantations, Western Ghats

Introduction and Background

Global amphibian declines have been the central theme of many conferences and symposia since the phenomenon was described in the late 1980s (Hayes et al. 2010; Lips 1998). Some driving factors of these declines have been identified as fragmentation and loss of habitat, pollution and increase in pesticide use, infection by chytrid fungus and other diseases, dam and water management systems, ultraviolet $\beta$ radiation, and the introduction of alien species (Alford and Richards 1999; Bickford et al. 2010; Blaustein and Kiesecker 2002; Cushman 2006; Hayes et al. 2010; Nowakowski et al. 2016; Stuart et al. 2004; Whitfield et al. 2007; Whitfield et al. 2013). Scientists are now referring to this period of declines and extinctions as the sixth global mass extinction event, and several direct anthropogenic effects are being compounded by global warming which is difficult to study (Wake and Vredenburg 2008). Rising temperatures in upland habitats are hypothesized to create conditions which are favorable for the growth of chytrid in areas that were historically not conducive for the fungus, especially high mountainous habitats which were historically too cold for Batrachochytrium dendrobatidis (Bd) (Pounds et al. 2006). Amphibians, many with a biphasic life history, have permeable moist skin and diverse modes of reproduction (Duellman and Trueb 1986). These animals function as natural biological indicators, and their declines signal possible declines in 
local environmental health (Daniels 1991; Lips 1998; McDiarmid 1994). The fungus Batrachochytrium dendrobatidis (Bd) has been identified as being responsible for a large number of mass amphibian die-offs in Australia and Central America (Berger et al. 1999; Lips 1998; Pechmann et al. 1991). When faced with such declines, although several short-term studies have been completed, it is imperative to have long-term monitoring projects of amphibians in place to enable sound conservation decisions derived from population trends of local species (Storfer 2003). Papers on amphibian ecology and conservation are on a rise and this is a very healthy sign, however, not all regions of the globe have been studied to the same extent as those in North America and Central America (Ficetola 2015; Whitfield et al. 2007). Several regions of high species endemicity are unfortunately the least studied. For example, we have little long-term ecological information regarding amphibians of the Western Ghats in India where scientists are still actively describing new species.

The Western Ghats (WG) are a part of the Malabar biogeographic region (Gadgil 1996; Rodgers and Panwar 1988). The WG form a continuous chain of small to medium-sized tropical mountain ranges running north to south nearly $1600 \mathrm{~km}$, along the west coast of southern India, from $8^{\circ}$ to $21^{\circ} \mathrm{N}$. The elevation is moderate compared to the Himalayas to the north; the hills generally vary between 600 and $1000 \mathrm{~m}$ asl elevation. The Western Ghats are hypothesized to have originated as the Indian plate was moving over the volcanic Deccan trap region (Bossuyt and Milinkovitch 2001; Briggs 2003; Karanth 2006; Radhakrishnan 1993). It is believed that the volcanic eruptions of the Deccan trap lead to the extinction of several old world species (Cretaceous-Tertiary extinction) and 
played a major role in the evolution of the biota of the Western Ghats (Bossuyt and Milinkovitch 2001). Bossuyt and Milinkovitch (2001) suggest that after the Deccan trap eruptions, the isolation of the Indian plate resulted in major speciation events. Ecological studies of this rich diversity has shown that the amphibian composition can vary greatly between two hills (separated by $<100 \mathrm{~km}$ ) in the same mountain range and the number of amphibian species increases as one moves south along the Ghats towards the equator (Daniels 1992).

The isolated hills of the Western Ghats may function as sky islands that support high levels of endemism in the biota. They have been hypothesized to serve as centers of speciation for amphibians, orchids and balsams (Aravind et al. 2007). Sky islands are isolated terrestrial islands that have varying degrees of connectivity (Robin et al. 2011; Warshall 1994). Robin et al. (2011) found that populations of White-Bellied Shortwing birds from different 'sky islands' in the Western Ghats varied in their songs. The populations of the White-bellied Shortwing (Brachypteryx majoron) on different mountains tops, as well as, recently isolated populations (as a result of deforestation) showing similar variations in their calls, that suggest that mountains of the Western Ghats act as isolated units allowing for speciation by geographical isolation (Robin et al. 2011). It might be expected that amphibian communities in the Western Ghats may be affected to a much greater extent by the ecosystem connectivity because of their limited dispersal capability. Watling and Donnelly (2006), after reviewing fragmentation studies that used the Equilibrium Theory of Island Biogeography to analyze the effects of fragment size and species richness, found that the effect of isolation was not studied in most cases. 
They observed that species on isolated mountain tops seemed to be more severely isolated than species in other patchy habitats, irrespective of the patch size (Watling and Donnelly 2006). Watling et al. (2011) found strong effects of the matrix composition in a meta-analysis on 184 different animal taxa found in 283 fragmented landscapes.

The vegetation of the Western Ghats varies from dry deciduous and deciduous rain forests, to montane and evergreen forests, with short stunted forests also called 'sholas' or 'stunted forests' and grasslands at high elevations (>1000m; Krishnamurthy 2003; Thomas and Palmer 2007). It might be expected that the amphibian biodiversity of the Western Ghats is influenced by variation in forest types, matrix type, altitude, latitude, the degree of isolation of each shola forest patch on an already isolated sky island and high overall species diversity could also be driven by high beta diversity (Watling and Donnelly 2006; von May 2009). The Western Ghats region in the 'Western Ghats and Sri Lanka Biodiversity Hotspot,' is home to over 384 amphibians, approximately $80 \%$ of which are endemic (Frost 2016; Mittermeier et al. 2011). Of these amphibian species from India, approximately $56 \%$ are found in the Western Ghats and more than 73 new species of amphibians have been described from India in the last 5 years (Figure 2.1; Dinesh et al. 2015a; Frost 2016). The number of new species continues to rise by the month (Figure 2.1; Frost 2016).

The endemism in the 'Western Ghats and Sri Lanka Biodiversity Hotspot' has been typically attributed to the subcontinent's geographical history of long-term isolation (Aravind et al. 2007; Bocxlaer et al. 2009; Dutta et al. 2004; Gunawardene et al. 2007). 
Phylogenetic studies also provide evidence of "back dispersal" of a single lineage of tree frogs from the island of Sri Lanka back to mainland India (Bossuyt et al. 2004). Of all the biodiversity hotspots in the world, the Western Ghats and Sri Lanka hotspot ranks the highest in human population density, with the Philippines, Caribbean, and Madagascar hotspots following the Indian site (Cincotta et al. 2000). The high anthropogenic pressure and the alarming rate of habitat loss in India are reason enough to monitor and to protect the biodiversity of this region (Gunawardene et al. 2007). Over $25.6 \%$ loss of forest cover has been reported in the states of Karnataka, Kerala, and Tamil Nadu from 1973 to 1995 (Gunawardene et al. 2007). However, in case of amphibians even with all these dramatic threats to the taxon, the rate of discovery of new species remains an increasing function because of the recent focus on amphibian research in India (Dinesh et al. 2015a; Frost 2016). Our knowledge regarding the distribution patterns, abundances and ecological interactions of these newly described species is still lacking (Aravind et al. 2007). Very few long-term community-level studies of amphibians have been conducted in India, and the present study focused on identifying the best standard surveying method for amphibians in the tea plantation landscape of the southern Western Ghats in Kerala, to identify methods used be in a comaparative study of sites across the tea plantation landscape.

Replacing natural vegetation with crops has been a part of regular landscape dynamics ever since humans ended their nomadic lifestyle and started to farm in $9000 \mathrm{BC}$ (Gignoux et al. 2011). Global deforestation rates are around 13 million hectares per year and most of this is concentrated in the tropics (Bremer and Farley 2010). Simultaneously, the 
annual rate of change of planted forests in the world has increased by $2.09 \%$ in the past 10 years, up from $1.88 \%$ in the decade before (FAO 2011a). Of late however, over 48\% of the global population lives in urban settlements, with several countries like the US and the UK, having long surpassed this statistic (Miller 2005). A lack of connection with the natural environment, because of life in urban settlements may drive a lack of empathy towards conservation (Miller 2005). With increasing human population size comes an increase in the demand for resources like food, timber, oil, and coffee and these demands are likely to increase in the future. Conversion of natural habitats to plantations cannot be prevented but ideally this conversion should inflict the least possible damage to the natural environment (Bali et al. 2007; Gardner et al. 2009; Wanger et al. 2010). Urbanization reduces unique habitats worldwide and encourages common species to thrive in altered conditions (Miller 2005).

Amphibians occupy intermediate positions in food webs because they act as both predator and prey. They primarily consume arthropods that in the brown food webs and they are consumed by larger animals, thus forming a connecting link in the food web (Reider et al. 2013). Gardner et al. (2007b) conducted studies on the effect of primary, secondary, and plantation forests on herpetofaunal diversity in the Brazilian Amazon and the results suggest that secondary forests might be able to provide habitats that can sustain a highly diverse community hosting up to two-thirds the amphibian diversity in the primary forests. There are several studies on amphibians in plantations; some showing an increase in species richness with fragmentation (Tocher et al. 1997) and others showing decreases (Gardner et al. 2007a; Hanlin et al. 2000; Vallan 2000); only 
two of these studies were conducted in India (Daniels 2003; Pawar et al. 2004). In his short study (six days in the wet season and four days in the dry season) Daniels (2003) reported 13 species of amphibians from a single tea estate; which include both seasonal and explosive breeding anurans (see Table. 2.2). The fact that such a short study revealed the presence of such a diverse anuran fauna suggests that the plantation landscape in the region provides some habitat for frogs. Ryan et al. (2002) in an attempt to monitor the herpetofauna of a managed ecosystem found that different sampling methods identified different species. Ryan et al. (2002) demonstrated that the study of amphibians and reptiles in plantations or other agro-ecosystems, requires pilot studies to choose the most appropriate sampling techniques. The results from Ryan et al. (2002) were a part of the motivation for the present study. In a recent study derived from 14 different global climate models (including data for 5527 species of amphibians), areas with the highest rates of amphibian decline, overlapped with regions most strongly affected by climate and land use changes (Hof et al. 2011). The fact that land-use change was more significant than effects of disease shows that habitat modification still remains the prime driver of amphibian decline. Apart from the direct effects on diversity, plantations also result in the fragmentation of the landscape, which affects the connectivity of populations (Becker et al. 2007). In case of vertebrates that cannot escape disturbed areas because of the limited capacity for dispersal, it is important to understand that disruptions, such as fragmented habitats can have strong effects on gene flow of species. In a detailed study trying to explain population gene flow patterns by landscape changes over time, Nowakowski et al. (2015) found that the genetic variation in the leaf-litter species Craugastor bransfordii was strongly explained by the prevalent landscape structure at the 
time of the study, while the genetic variation in another leaf-litter amphibian, Oophaga pumilio, was explained partially by a combination of isolation and old barriers. The realized permeability of similar habitats was different in each of these species and the authors placed emphasis on this as a factor that makes gene flow very species specific (Nowakowski et al. 2015). In another study, Becker et al. (2007) observed that species with aquatic larval stages seemed most affected by fragmentation.

While keeping track of species, presence/absence data are just one type of data. Information on the abundances of the species using methods that are comparable are extremely important to be able to track the health of populations over time (Campbell and Christman 1982; Hayek 1994; Mengak and Guynn 1987; Rodda et al. 2001; Stoffer 2003). Each standard method has several assumptions and it is important to ensure that the underlying assumptions are met, or addressed while interpreting the data (Heyer et al. 1994). There are several standard methods described for sampling amphibians that are developed by studies in certain parts of the world do not function with the same efficiency globally (Storfer 2003). Other methods can be successful implemented in different places, for example, Pearman (1997) in Ecuador, Doan (2003) in Peru and Donnelly et al. (2005) in Guyana.

The availability of resources such as capital, human power, terrain, and the species in question, all affect the success rates of the methods used (Doan 2003; Storfer 2003; Donnelly et al. 2005). A 2001 study conducted in Brazil comparing the Large Plot Method (LPM) versus the Small Plot Leaf Removal (SPLR) method, found that the 
former method underestimated the diversity of the region though the SPLR method is known to be a 'quasi destructive' method (Rocha et al. 2001). The need to understand the short-comings of a method is well exhibited by Bridges and Dorcas (2000), when the usual post midnight to dawn calls of the species Rana sphenocephala during the month of July were noticed. The call of the species was completely missed when using standard methods that were stopped at midnight (Bridges and Dorcas 2000). Donnelly et al. (2001) were unable to use the pit fall traps with a drift fence method for several months because the elevated water table pushed the buckets out of the ground during El Niño flooding. In a study comparing random quadrats and adaptive cluster sampling in the Sothern Western Ghats, Vasudevan et al. (2001) found that the latter gave density estimates which were almost three times of that using the random quadrat method. In certain areas a combination of methods need to be used to find species that occupy very different niches, since they cannot all be encountered by using a single method (Ryan et al. 2002). Some methods are more efficient than others, and depending on the habitat in question and the terrain of the study site (Doan 2003). When a mix of transects and pitfall traps were used to study amphibians in Mississippi, it was seen that no single method represented the diversity of the region as well as all methods combined (Fogarty and Jones 2003). However, the pit fall trap captures were predated upon by raccoons, which may have lead to an underestimation of the diversity in some sites (Fogarty and Jones 2003).

In India, Vasudevan et al. (2006) reported a high turnover of amphibian species in the Anamalai hills of the southern Western Ghats, with about 40 species each in neighboring hill ranges separated by $>2$ degrees of longitude, while the total regional species richness 
of the landscape was 130 species. Naniwadekar and Vasudevan (2007) reported that intense transect surveys and Visual Encounter Survey's accounted only for $49 \%$ and $83 \%$ of the species documented in the study site in Kalakad Mundanthurai Tiger Reserve, Tamil Nadu, India. They also reported that the alpha diversity increased with elevation and that there were more than two peaks of diversity, when considering gamma level diversity. Sung et al. (2011) in a study in Hong Kong used cover-boards, pitfall traps and transects to survey herptofauna and found that transects were better for a quick diversity count while combinations of methods gave the largest number of animals. It is important to find the best methods for an area to maximize the use of available resources. Sampling methods must provide data that answers questions effectively. If an accurate species list is the goal then all the methods including opportunistic observations, must be employed. Ideally one has a large number of methods with high returns for investment in costs of supplies and and human resources

The present study tests the efficiency of established standard methods in a tea plantation landscape in the southern Western Ghats of India. In this chapter I describe the amphibian community in three different habitats, shola forests, eucalyptus forests, and tea, within a large tea plantation landscape using Visual encounter surveys (VES), stream transects (ST), and drift fences with funnel traps (DF). The site mimics a classic terrestrial island-matrix fragmented landscape (Gardner et al. 2007b; Watling and Donnelly 2006). I predict the native shola patches in the area will have the highest richness and abundance of anurans species. I also predict that the VES method will be the most efficient method, as it is a popular method used successfully across different 
habitats globally. Since tea cultivation is important across India and across the world, my study provides important background information regarding sampling amphibians in this large agro-ecosystem, from a site in a biodiversity hotspot.

\section{Study Area}

This study was conducted near the town of Munnar, in the state of Kerala in the Southern Western Ghats of India. Kerala is an important producer of tea in South India accounting for $8.5 \%$ of the total production of India. Munnar falls under the Devikulam Forest Division (Figure 2.2). The word 'Munnar', translates into three rivers; Kadalar, Nallathanni Aar, and Kallar. The Munnar mountain range in the Munnar Forest Division has over $106 \mathrm{~km}^{2}$ of reserve forest, most of which is interspersed among tea plantations. The elevation varies from $600 \mathrm{~m}$ asl to $2695 \mathrm{~m}$ asl which is on Anamudi (Elephant Peak), the highest peak in peninsular India. Though present in the tropical zone, the climate in this area is moderated by altitude. Munnar receives rainfall both during the Southwest and the Northeast monsoons. The Southwest monsoons account for over $80 \%$ of the annual precipitation and occur during June and July, and the rest of the precipitation is received during Northeast monsoon which from October to November (Figure 2.3). The minimum temperature in the last three years was $0^{\circ} \mathrm{C}$ and the maximum temperature in the last three years was $29^{\circ} \mathrm{C}$ (Figure 2.4). The humidity in these areas is high year around, usually above $80 \%$. The area supports wet evergreen forest, semi-evergreen forest, moist deciduous forest, dry deciduous forest, broad-leaved hill forest, montane wet temperate forest, and grasslands according to the revised classification (Champion and Seth 1968; Thomas and Palmer 2007). I conducted surveys in the Kanan Devan Hills 
Tea Plantation Company Private Limited (henceforth KDHP; $10^{\circ} \mathrm{N}$ and $77^{\circ} \mathrm{E}$ ) located in the Idukki district, of Kerala, in the Southern Western Ghats. Tea plantations in this area were originally established in 1877, after John Daniel Munro leased the land from the Poonjar Chief without any time stipulation (KDHP Management Plan 2002) and have been actively harvested ever since. The Kanan Devan Hills Tea Plantation Cooperation Private Limited was established in 2005 and is a $238 \mathrm{Km}^{2}$ holding, $98 \mathrm{Km}^{2}$ of which is under tea cultivation (Figure 2.3). The plantation holdings include 27 tea estates under the same management plan. The other major habitat types, in addition to tea are eucalyptus patches and remnant patches of shola forest. The plantation shares borders with the Eravikulam National Park (established in 1978), a $100 \mathrm{~km}^{2}$ tract of undulating highlands, including Anamudi, that was originally a part of the tea plantation (KDHP Management Plan 2002). The company donated the land to the Government of India to create a park to protect the critically endangered Nilgiri Tahr, an endemic mountain goat (KDHP Management Plan 2002; Thomas and Palmer, 2007). Other tea plantations in the area are owned by American Direct Tea Trading Cooperation Limited, Thalayar Tea, The Malayalam Plantation Limited, and some private plantation holdings.

The KDHP plantation was chosen, because it was the single largest land holding in the region. In tea plantations, tea bushes are maintained at a height of approximately $1.5 \mathrm{~m}$ to facilitate hand picking and they are planted $50 \mathrm{~cm}$ from each other in rows. My study was conducted in the Kannaimallai and Perriavarai plantations approximately $7 \mathrm{~km}$ East of Munnar (Figure 2.2.). Drift fences made of plastic sheeting ( $8 \mathrm{~m} \mathrm{long}$ ) with wire funnel traps, nocturnal visual encounter surveys, and stream transects were tested at sites located 
at elevations between 1500 and $2000 \mathrm{~m}$ asl to avoid elevation effects. The southern montane temperate forests (shola forests) interspersed within tea fields were one of the focal habitats of my study. These natural forests usually grow in shallow mountains valleys that are protected from harsh climatic events. The trees are seldom taller than $10 \mathrm{~m}$ and they are stunted forests. The families of trees represented includes Lauraceae, Rubiaceae, Symplocacaeae, Myrtaceae, Myrsinaceae, and Oleaceae (Bunyan et al. 2012; Champion and Seth 1968). Sholas forests are usually found above $1500 \mathrm{~m}$ asl. It is mostly forests of this type along with grasslands between the shola that were cleared to establish tea plantations over 130 years ago. There are two schools of thought regarding the presence of these high elevation grasslands: 1) they are the climax ecosystem in the area and 2) they are a pre-climax ecosystem that is limited by fire and frost (Bunyan et al. 2012; Thomas and Palmer 2007). At elevations above 1800m, most of the land that is not covered by rock faces is covered by grasslands. Almost $80 \mathrm{Km}^{2}$ of this area has been converted into fuel wood stands of eucalyptus which are harvested every seven years. The most common tree used for fuel is eucalyptus which in addition to being used to dry tea during its processing is also used as fire wood by the tea picking community.

\section{Methods}

This study was focused on anurans. Standard animals handling protocols were approved by Florida International University's Institutional Animal Care and Use Committee (IACUC-12-004 \#A3096-01). Four standard methods (Diurnal and Nocturnal Visual Encounter Eurveys, drift fences with funnel traps, and VES along stream transects) were 
used to sample anurans and build a species list for the tea estate. For all the methods, except the funnel traps, animals were captured by hand or by small aquarium net to ensure that the animal was exposed to minimal stress. Upon capture, frogs were identified to species or morphospecies, measured (snout-to-vent length in $\mathrm{mm}$ ) with a plastic field calipers (SPI Plastic Dial Caliper Model 31-415-3), weighed by placing the animal in a clean plastic bag and weighing it with a Pesola scale $\left(\right.$ Pesola ${ }^{\circledR}$ LightLine Spring Scales, $10 \mathrm{~g}$ and $30 \mathrm{~g}$ ) to the nearest $\mathrm{mg}$ and released at the middle of the transect (Crump and Scott 1994). Any species encountered off transects were added to the species list to make it complete, but these opportunisitc data were not used in any statistical comparisons. Detection probability was maintained uniformly by having the same two observers work during the period of the study and alternating the order among transects. Spatial autocorrelation was avoided by sampling habitats which were not contiguous with each other and by using different streams. The experimental design ensured that transects in each habitat type (tea, shola, eucalyptus, and streams) were sampled in a single night to avoid bias of anuran detection because of differences among nights. Data from nights during which sampling was interrupted because of heavy rain or dangerous animal encounters (elephants and gaurs) were discarded from the analysis. Four replicates were established for each of the habitats and each of these were at least a km apart (Figure. 2.5). Data were collected during the monsoons from June to November, 2012. $\underline{1.1}$ and 1.2 Nocturnal and Diurnal Visual Encounter Surveys (VES): These are standard methods used for sampling amphibians and reptiles which are found on the ground and on bushes and trees. I set up $25 \mathrm{~m}$ long transects in all the three habitat types (sholas, tea and eucalyptus). The transects were marked at every $5 \mathrm{~m}$ with flagging tape. The VES 
method involved two people walking along the transect and searching carefully for frogs, $1 \mathrm{~m}$ on either side of the transect line and up to $2 \mathrm{~m}$ above the ground for 15 minutes (Crump and Scott 1994). The transects were conducted during the day (09:00hrs12:00hrs) and the night (19:00hrs-00:00hrs using Black Diamond Icon Headlamp). The start of each transect within a particular habitat was at least $5 \mathrm{~m}$ away from a different habitat type.

1.3 Stream sampling with Nocturnal VES: Stream transects were set up in the habitats for $25 \mathrm{~m}$ in both tea and shola habitats. The transect were at marked every $5 \mathrm{~m}$ using flagging tape on vegetation in the riparian zone. The VES method involves two people walking in the middle of the stream searching carefully for frogs, $1 \mathrm{~m}$ on either side of the transect line and up to $2 \mathrm{~m}$ above the ground for $15 \mathrm{mins}$ (Crump and Scott 1994). The transects were sampled between 09:00 hrs-12:00hrs and 19:00hrs-00:00hrs using headlamps for nocturnal surveys. Each stream was independent.

1.4 Drift Fence with Funnel Traps: This method involves placement of $8 \mathrm{~m}$ long plastic barrier fences with funnel traps on each end to capture amphibians moving through the habitat. The method is free of investigator bias (detection is equivalent for all captures) and generates a catch-per-unit-effort value for analysis of the number of captures per trap hour (Corn 1994). In some cases, drift fences are the best method for surveying sites and capturing secretive amphibians (Corn 1994). When animals contact the plastic fence they can turn completely around and walk away but often animals walk along the fence and enter the funnel trap at the end of the fence. The fence made from three plastic sheets, $8 \mathrm{~m}$ long and three funnel traps were placed on each end (Corn 1994). Four replicates of drift fences with funnel traps (Figure 2.6) were deployed in the three different habitats and 
trapping was conducted for seven consecutive nights, which is a total of 84 trap nights. The effort to set up these traps was high and it took eight person hours (two people working for four hours) to set up each array and as well as, hiking up twice a day regularly to the traps to check for captures was also quite high.

Analysis and Results

The lowest temperature recorded in the area in 2012 was $1^{\circ} \mathrm{C}$ during a few days in February and the highest temperature recorded was during the month of May and was $28^{\circ} \mathrm{C}$. The area is reported to have a few days of frost during the month of January or February. The Southwest monsoons arrived on the 3 June as predicted by the Meteorological Department of India. The average of minimum and maximum temperatures for the study site is plotted in Figure. 2.3. The area received $3859.02 \mathrm{~mm}$ of rainfall in the year when the study was conducted. The rainfall received in 2012 lies between the usual average (add year here) of rainfall received annually in the area. Of this $2848.86 \mathrm{~mm}$ was received in the months of June, July, and August during the South West Monsoon, in 2012. Therefore, $73.8 \%$ of the annual rainfall was received in just three months (Figure 2.4).

A total of 407 individual frogs from 17 species. Since I coulnd not differentiate among juvenile Raorchestes species all of them were put in one category and were not included in species richness measures. were encountered during the months of June to November using the standard methods (Table 2.2). The maximum number of individuals were sampled in the month of July, followed by June, and September (Figure 2.7). Seven 
species encountered during the study are in the first three threat categories of the IUCN red list, and five are considered to be data deficient (IUCN 2016). Of these, four species are critically endangered, one is vulnerable, and the other two were reported as near threatened (IUCN 2016). Species from three genera, Fejervarya, Micrixalus, and Indirana are categorized together as Fejervarya sp., Micrixalus sp., and Indirana sp., respectively, as the individuals could not differentiated with confidence in the field. The genus Micrixalus was recently revised and 14 new species described (Biju et al. 2014). Eight new species of have been described from Kerala which are not easily distinguishable in the field. The species were described on the basis of molecular differences (Biju et al. 2014). Nair et al. (2012) revised the genus Indirana and found the presence of many cryptic species that await description. Dinesh et al. (2015b) revised the genus Fejervarya and call for caution in identifying species of this genus in the field because of uncertainties associated with collection of types and of the locations of historical collections. These cryptic species suggest that my list is conservative for these two plantations and is likely to include several more species. I generated Coleman curves for the data set to estimate the number of species using each the standard method in each habitat (Figure 2.8). The number of species in each of the transects sampled was averaged after 100 randomizations to remove the difference associated with the sampling order and the variation in the number of individuals collected per sample. The analysis was conducted using the community ecology vegan package in the software $\mathrm{R}$ version 3.3.0 (Oksanen et al. 2015). 
1.1 Diurnal Visual Encounter Surveys: After seven days of diurnal VESs, this method was discontinued because I had zero detections.

1.2 Nocturnal Visual Encounter Surveys: A total of 68 nocturnal VESs were conducted in each of the three habitat types from June to November 2012. During the VES sampling a total of 102 hours was spent in all the three habitats (Table. 2.4). A total of ten species were encountered in the shola forests and of these two species were found exclusively in the shola forest transects (Table. 2.2 and Figure 2.10). The species Rhacophorus pseudomalabaricus and Ghatixalus magnus both arboreal species, which depend on streams for reproduction, were found only in shola stream transect. Eight species were detected in tea bushes with a single bush frog species, Raorchestes jayarami being exclusive to the tea habitat. Seven amphibian species were encountered in eucalyptus forests and two species, frogs from the genus Fejervarya and Uperodon cf. montanus were found only along transects in eucalyptus (Table. 2.2).

1.3 Stream sampling with Nocturnal VES: A total of 98 transects each were conducted in tea (49) and shola (49) streams from June to November, 2012. Nine species of amphibians were encountered in the shola stream transects and seven species were encountered in the tea stream transects, with three amphibian species, Raorchestes chlorosomma, R. munnarensis, and R. dubois found exclusively in shola stream transects and frogs in the genus Fejervarya were found exclusively in tea steam transects (Table. 2.2 and Figure 2.10). The total number of individuals sampled using the stream transects was 173 (Table. 2.3). 
1.4 Drift Fence with Funnel Traps: Four replicates of drift fences with funnel traps were deployed in the three different habitats and trapping was conducted for seven consecutive nights from July 27 to August 4, 2012 (4x3x7=84 trap nights) for 2016 trap-hours. A total of four individual frogs from two species (Duttaphrynus melanostictus and Indirana species) were trapped, two each in tea and eucalyptus habitats and none in shola forest. These two species are terrestrial and are wide spread in India with $D$. melanostictus being one of the most widely distributed species in the country.

I used the community ecology packages vegan from the software package $\mathrm{R}$ (Version.3.3.0) to calculate a Bray Curtis dissimilarity matrix of the total data from each transect (Oksanen et al. 2015). A Meta non-Metric Dimensional Scaling plot (meta nMDS) was constructed and best fit polygons were constructed around sites using the standard sampling method used, as well as, the habitat type (Figure. 2.10 and Figure 2.11). The composition of species obtained using visual encounter surveys were more similar to each other than the species obtained from stream transects. The anuran species community from transects in the tea, sholas, and eucalyptus habitats showed statistically significant differences (Figure 2.11).

Discussion

The Visual Encounter Survey method deployed at night worked most efficiently in the tea estates at my study site in Munnar, Kerala. The species found only in the tea field 
transects, Rarochestes jayarami, was described in 2010 from five male specimens collected in forest undergrowth in Valparai, Tamil Nadu (Biju and Bossuyt 2009). Bush frogs have direct development, which means that they lay their eggs outside of water unlike anurans with a generalized amphibian life cycle (Biju and Bossuyt 2009;

Duellman and Trueb 1986). The tea bushes seem to be providing R. jayarami a hospitable microhabitats (Biju and Bossuyt 2009). Rarochestes jayarami was also commonly seen inside the houses of tea plantation workers, suggesting that it is tolerant of human-caused disturbance.

Rhacophorus pseudomalabaricus and Ghatixalus magnus, both rhacophorids found only from the shola forests transects, are species that are usually found in forests trees but move down to vegetation over-hanging streams during the breeding season (Abraham et al. 2015; Vasudevan and Dutta 2000; Harpalani et al. 2015). Rhacophorus pseudomalabaricus was spotted in large numbers around low over-hanging vegetation and eucalyptus trees surrounding a marshy area in the tea plantation during the months of June and July (Harpalani et al. 2015) but not in the transects that were randomly selected for the study. Ghatixalus magnus was only described in 2015 and we do not have much information about the life history of this species (Abraham et al. 2015). Although I encountered two adults, I did not witness any breeding behavior or observe tadpoles. The three Fejervarya species and Uperodon cf. montana were found only in the eucalyptus patches and are terrestrial frogs in the tea plantation. Frogs from the genus Fejervarya were often spotted in marshy areas that were scattered across the Kanniamallai estate. Uperodon cf. montana was only spotted in a eucalyptus forest transect, but it was 
observed in other locations off the transects in tea fields. In one instance, over 30 individuals were spotted on the bases of pruned tea bushes in a tea field. Frost (2016) reports that this taxon is a complex of morphologically similar species. Little is known about the breeding behavior of Uperodon cf. montana. Though Krishna and Bosch (2007) report the closely related species Uperdon montana males, were seen calling from tree holes, I have seen instances of males calling while floating in puddles of water on access paths in the plantations. Sandeep Das (personal communication) also observed the same male calling behavior as well as egg laying by female Uperodon cf. montana in puddles along access ways in cardamom plantations in Tamil Nadu. While the Nocturnal Visual Encounter Survey and the Stream transects gave the best catch-per-effort, the funnel traps with drift fence methods were not successful in this landscape (Table. 2.3). The highest diversity per person-hour was obtained using stream transects in the Shola forest, followed by nocturnal VES in eucalyptus forests (Table. 2.3). The highest number of individuals per person-hour was also obtained using the stream transect method in the shola forest, followed by the VES in shola forests (Table. 2.3). The slight overlap of the species composition shown in the nMDS plot during visual encounter surveys and stream transects was because of the species Duttaphrynus melanostictus, and juvenile Raorchestes species which were encountered using both methods (Figure 2.10). We recommend that the Stream Transect method and the nocturnal Visual Encounter Survey methods are the most efficient methods for standard surveys of anurans in the tea plantation landscape of the Southern Western Ghats. More specific methods around breeding swamps are likely to target other species as well (Scott and Woodward 1994). My difference in community composition in close by transects provides some support for 
the idea that the high species diversity of the Western Ghats is explained by high beta diversity. Taxonomy and field identification is a challenge for species complexes, but there are now baseline data for two plantations in Munnar during the monsoon season (June-November).

Urbanization reduces unique habitats worldwide and encourages common, less sensitive flora and fauna to thrive (Miller 2005). Sometimes different methods applied in the same region provide different estimates of richness and abundance, hence a combination of methods is better or at least the least expensive method can be applied (Rocha et al. 2001). In some cases, the knowledge of the most efficient method for amphibian surveying can help in situations were rapid assessments of diversity are required (Vonesh et al. 2009). Studies comparing standard methods provide information on the time, money, and other logistics that are required for a particular method. Roelants et al. (2007) calculated the background rate of extinction of amphibians as 200-2700 times faster than the norm of 0.2926 events per lineage per million years using the number of extinctions in the past 26 years. The predicted rates of extinction are reason enough to encourage more studies of amphibian diversity, life history, behavior and all other areas possible.

\section{Acknowledgements}

I thank Florida International University for a graduate assistantship which allowed for data collection. I thank the Wildlife Institute of India, Dehradun, India and Dr. Karthikeyan Vasudevan for the Research Associate post provided from 2012 to 2015. I 
thank the KDHP Private Ltd. for permission to work on the tea plantation property in Munnar, Kerala and I also thank Elangovan for help with field work.

Literature Cited

Abraham, R.K., Mathew, J.K., Cyriac, V.P., Zachariah, A., Raju, D.V. and Zachariah, A., 2015. A novel third species of the Western Ghats endemic genus Ghatixalus (Anura: Rhacophoridae), with description of its tadpole. Zootaxa. 4048:101-113.

Alford, R. A., and S. J. Richards. 1999. Global amphibian declines: A problem in applied ecology. Annual Review of Ecology and Systematics. 30:133-165.

Aravind, N. A., Tambat, B, Ravikanth, G., Ganeshaiah, K. N., and R. Uma Shaanker. 2007. Pattterns of species discovery in the Western Ghats a megadiversity hot spot in India. Journal of Biosciences. 32:781-790.

Bali, A., Kumar, A. and J. Krishnaswamy. 2007. The mammalian communities in coffee plantations around a protected area in the Western Ghats, India. Biological Conservation. 139:93-102.

Becker, C. G., Fonseca, C.R., Haddad, C.F.B., Batista, R.F., Prado, P.I., 2007. Habitat split and the global decline of amphibians. Science. 318:1775-1777.

Berger, L., Speare, R., and A. D. Hyatt. 1999. Chytrid fungi and amphibian declines: Overview, implications and future directions. Tropical Medicine. Canberra. 2333.

Bickford, D., Howard, S. D., Ng D. J. J., and J. A. Sheridan. 2010. Impacts of climate change on the amphibians and reptiles of Southeast Asia. Biodiversity Conservation. 19:1043-1062.

Biju, S. D. and Bossuyt, F., 2009. Systematics and phylogeny of Philautus Gistel, 1848 (Anura, Rhacophoridae) in the Western Ghats of India, with descriptions of 12 new species. Zoological Journal of the Linnean Society. 155:374-444.

Biju, S. D., Garg, S., Gururaja, K.V., Shouche, Y. and Walujkar, S.A., 2014. DNA barcoding reveals unprecedented diversity in dancing frogs of India (Micrixalidae, Micrixalus): A taxonomic revision with description of 14 new species. Ceylon Journal Science (Biological Sciences). 43:37-123.

Blaustein, R. A., and M. J. Kiesecker. 2002. Complexity in conservation: Lessons from the global decline of amphibian populations. Ecology Letters. 5:597-608. 
Bocxlaer, I. V., Biju, S. D., Loader, S. P., and F. Bossuyt. 2009. Toad radiation reveals into-India dispersal as a source of endemism in the Western Ghats-Sri Lanka biodiversity hotspot. BMC Evolutionary Biology. 9:131-141.

Bossuyt, F., Meegaskumbura, M., Beenaerts, N., Gower, D. J., Pethiyagoda, R., Roelants, K., Mannaert, A., Wilkinson, M., Bahir, M. M., Manamendra-Arachchi, K., Ng, P. K. L., Schneider, C. J., Oommen, O. V., and M. C. Milinkovitch, 2004: Local Endemism Within the Western Ghats-Sri Lanka Biodiversity Hotspot. Science. 306:479-481.

Bossuyt, F., and M. C. Milinkovitch. 2001. Amphibians as indicators of early tertiary "out- of-India" dispersal of vertebrates. Science. 292:93-95.

Bremer, L. L., Farley KA. 2010. Does plantation forestry restore biodiversity or create green deserts? A synthesis of the effects of land-use transitions on plant species richness. Biodiversity Conservation. 19:3893-915.

Bridges, A.S. and Dorcas, M.E., 2000. Temporal variation in anuran calling behavior: Implications for surveys and monitoring programs. Copeia. 2000: 587-592.

Briggs, J. C. 2003. The biogeographic and tectonic history of India. Journal of Biogeography. 30:381-388.

Bunyan, M., Bardhan, S., and Jose, S. 2012. The shola (Tropical Montane Forest)grassland ecosystem mosaic of peninsular India: A review. American Journal of Plant Sciences. 3:1632-1639.

Campbell, H. W., and S. P. Christman. 1982. Field techniques for herpetofaunal community analysis. Pages 193-200 in N. J. Scott, Jr., ed. Herpetological communities. U.S. Fish and Wildlife Services, Wildlife Research Report. 13.

Champion, H.G., Seth, S.K., 1968. A revised survey of the forest types of India. Government of India Publication, New Delhi.

Cincotta, P. R., J. Wisnewski, and R. Engelman. 2000. Human population in the biodiversity hotspots. Nature. 404:990-992.

Corn, P. S. 1994. Straight line drift fences and pitfalls. Pages 109-117 in W. R. Heyer, M. A. Donnelly, R. W. McDiarmid, L. A. C. Hayek, and M. S. Foster, editors. Measuring and monitoring biological diversity: Standard methods for amphibians. Smithsonian Institution Press, Washington, D.C., USA.

Crump, M. L., and N. J. Scott. 1994. Visual encounter surveys. Pages 84-92 in W. R. Heyer, M. A. Donnelly, R. W. McDiarmid, L. A. C. Hayek, and M. S. Foster, editors. Measuring and monitoring biological diversity: Standard methods for amphibians. Smithsonian Institution Press, Washington, D.C., USA.

Cushman, S.A., 2006. Effects of habitat loss and fragmentation on amphibians: A review and prospectus. Biological Conservation. 128: 231-240. 
Daniels, R. J. R. 1992. Geographical distribution patterns of amphibians in the Western Ghats, India. Journal of Biogeography. 19: 521-529.

Daniels, R. J. R. 2003. Impact of tea cultivation on anurans in the Western Ghats. Current Science. 85:1415-1422.

Dinesh, K. P., Radhakrishnan, C., Gururaja, K. V., and Bhatta, G. K. 2009. An annotated checklist of Amphibia of India with some insight into the patterns of species discoveries, distribution and endemism. Records of the Zoological Survey of India, Occasional Paper No. 302:1-153.

Dinesh, K. P., Radhakrishnan, C., Channakeshavamurthy, B. H., and N. U. Kulkarni. 2015a. Checklist of Amphibia of India. Mhadeiresearchcenter.org

Dinesh, K.P., Vijayakumar, S.P., Channakeshavamurthy, B.H., Torsekar, V.R., Kulkarni, N.U. and Shanker, K., 2015b. Systematic status of Fejervarya ((Amphibia, Anura, Dicroglossidae) from South and SE Asia with the description of a new species from the Western Ghats of Peninsular India. Zootaxa. 3999:079-094.

Doan, T. M. 2003. Which methods are most effective for surveying rain forest herpetofauna? Journal of Herpetology. 37:72-81.

Donnelly, M.A., Baber, M.J. and Farrell, C.J., 2001. The amphibians and reptiles of the Kissimmee River. II. Patterns of abundance and occurrence in hammocks and pastures. Herpetological Natural History. 8:171-179.

Donnelly, M. A., Chen, M. H., and G. G. Watkins. 2005. Sampling amphibians and reptiles in the Iwokrama Forest Ecosystem. Proceedings of the Academy of Natural Sciences of Philadelphia. 154: 55-69.

Duellman, W.E. and Trueb, L., 1986. Biology of amphibians. Johns Hopkins Press.

Dutta, S. K., Vasudevan, K., Chaitra, M. S., Shanker, K. and R. Aggarwal. 2004, Jurassic frogs and the evolution of amphibian endemism in the Western Ghats. Current Science. 86: 211-216.

FAO, 2011a. Global Forest Resources Assessment. 2010. www.fao.org, Rome, Italy.

FAO, 2011b. State of the World's Forests. 2011. www.fao.org, Rome. Italy.

Ficetola, G. F. 2015, Habitat conservation research for amphibians: Methodological improvements and thematic shifts. Biodiversity and Conservation. 24:1293-1310.

Fogarty, J.H. and Jones, J.C., 2003. Pitfall trap versus area searches for herpetofauna research. In Proceedings of the Annual Conference of the Southeastern Association of Fish and Wildlife Agencies. 57: 268-279.

Frost, D. R. 2016. Amphibian Species of the World: An Online Reference. Version 6.0 (August, 2016). http://research.amnh.org/herpetology/amphibia/index.html. American Museum of Natural History, New York, USA. 
Gadgil, M., 1996. Documenting diversity: An experiment. Current Science. 70:36-44.

Gardner, T.A., Barlow, J., and C. A. Peres. 2007b. Paradox, presumption and pitfalls in conservation biology: The importance of habitat change for amphibians and reptiles. Biological Conservation. 138: 166-179.

Gardner, T.A., Barlow, J., Chazdon, R.L., Ewers, R.M., Harvey, C.A., Peres, C.A., and N. S. Sodhi. 2009. Prospects for tropical forest biodiversity in a human-modified world. Ecology Letters. 12:561-582.

Gardner, T.A., Ribeiro-Junior M.A., Barlow J., Avila-Pires T.C.S., Hoogmoed M.S., and C. A. Peres. 2007a. The value of primary, secondary, and plantation forests for a neotropical herpetofauna. Conservation Biology. 21:775-787.

Gignoux, C.R., Henn, B.M. and Mountain, J.L., 2011. Rapid, global demographic expansions after the origins of agriculture. Proceedings of the National Academy of Sciences. 108: 6044-6049.

Gunawardene, N.R., Daniels, D.A., Gunatilleke, I.A.U.N., Gunatilleke, C.V.S., Karunakaran, P.V., Nayak, G.K., Prasad, S., Puyravaud, P., Ramesh, B.R., Subramanian, K.A. and Vasanthy, G., 2007. A brief overview of the Western Ghats-Sri Lanka biodiversity hotspot. Current Science. 93:1567-1572.

Hanlin, H.G., Martin, F.D., Wike, L.D., and S. H. Bennett. 2000. Terrestrial activity, abundance and species richness of amphibians in managed forests in South Carolina. American Midland Naturalist. 143:70-83.

Harpalani, M., Parvathy, S., Kanagavel, A., Eluvathingal, L. and Tapley, B., 2015. Note on range extension, local knowledge and conservation status of the Critically Endangered Anamalai gliding frog Rhacophorus pseudomalabaricus in the Cardamom Hills of Western Ghats, India. Herpetological Bulletin. 133:1-6.

Hayek, Lee-Ann, C. 1994. Analysis of Amphibian Biodiversity Data. Pages 207-261 in W. R. Heyer, M. A. Donnelly, R. W. McDiarmid, L. A. C. Hayek, and M. S. Foster, editors. Measuring and monitoring biological diversity: Standard methods for amphibians. Smithsonian Institution Press, Washington, D.C., USA.

Hayes, T.B., Falso, P., Gallipeau, S. and Stice, M., 2010. The cause of global amphibian declines: a developmental endocrinologist's perspective. The Journal of Experimental Biology. 213:921-933.

Heyer, W.R., Donnelly, M.A., McDiarmid, R.W., Hayek, L.C., Foster, M.S., 1994. Measuring and monitoring biological diversity. In: Standard Methods for Amphibians, Smithsonian Institution Press.

Hof, C., Araújo, M. B., Jetz, W., and Rahbek, C. 2011. Additive threats from pathogens, climate and land-use change for global amphibian diversity. Nature. 480:516-519.

IUCN 2016. The IUCN Red List of Threatened Species. Version 2016-2. $<$ http://www.iucnredlist.org $>$. Downloaded on 04 September 2016. 
KDHP Management Plan 2002. Munnar Press.

Kanan Devan Hills Private Cooperation Limited, 2016.

www.kdhptea.com/plantation_map.html

Karanth, K.P., 2006. Out-of-India Gondwana origin of some tropical Asian biota. Current Science. 90:789-792.

Krishna, S.N. and Bosch, J., 2007. The breeding behavior and advertisement calls of the tree-hole breeding frog Ramanella montana (Microhylidae) in the Western Ghats, S. India. Acta Zoologica Sinica. 53:575-578.

Krishnamurthy, S.V. 2003. Amphibian assemblages in undisturbed and disturbed areas of Kudremukh National Park, central Western Ghats, India. Environmental Conservation. 30: 274-282.

Lips KR. 1998. Decline of a tropical montane amphibian fauna. Conservation Biology. 12:106-17.

Longcore, J.E., Pessier, A.P., Nichols, D.K.. 1999. Batrachochytrium dendrobatidis gen. et sp. nov., a chytrid pathogenic to amphibians. Mycologia. 91:219-227.

McDiarmid, Roy W. 1994. Amphibian diversity and natural history: An overview. In: Heyer, W. R., Measuring and Monitoring Biological Diversity: Standard Methods for Amphibians. Smithsonian Institution Press. 5-15.

Mengak, M. T., and D. C. Guynn JR. 1987. Pitfalls and snap traps for sampling small mammals and herpetofauna. The American Midland Naturalist. 118:284-288.

Miller, J. R. 2005, Biodiversity conservation and the extinction of experience. Trends in Ecology and Evolution. 20:430-434.

Mittermeier, R.A., Turner, W.R., Larsen, F.W., Brooks, T.M. and Gascon, C., 2011. Global biodiversity conservation: the critical role of hotspots. In Biodiversity hotspots (3-22). Springer Berlin Heidelberg.

Naniwadekar, R. and Vasudevan, K., 2007. Patterns in diversity of anurans along an elevational gradient in the Western Ghats, South India. Journal of Biogeography. 34:842-853.

Nair, A., Gopalan, S.V., George, S., Kumar, K.S., Teacher, A.G.F. and Merilä, J., 2012. High cryptic diversity of endemic Indirana frogs in the Western Ghats biodiversity hotspot. Animal Conservation. 15:489-498.

Nowakowski, A.J., DeWoody, J.A., Fagan, M.E., Willoughby, J.R. and Donnelly, M.A., 2015. Mechanistic insights into landscape genetic structure of two tropical amphibians using field-derived resistance surfaces. Molecular Ecology. 24: 580595. 
Nowakowski, J. A., Watling, J. I., Whitfield, S. M., Todd, B. D., Kurz, D. J., and M. A. Donnelly. 2016. Tropical amphibians in shifting thermal landscapes under land use and climate change. Conservation Biology. DOI: 10.1111/cobi.12769.

Pawar, S.S., Rawat, G.S., and B. C. Choudhury. 2004. Recovery of frog and lizard community's alteration in Mizoram, Northeast India. BioMed Central Ecology. DOI:10.1186/1472-6785-4-10.

Pearman, P.B., 1997. Correlates of amphibian diversity in an altered landscape of Amazonian Ecuador. Conservation Biology. 11:1211-1225.

Pechmann, J. H. K., Scott, D. E., Semlitsch, R. E., Caldwell, J. P., Vitt, L. J., and J. W. Gibbons. 1991. Declining amphibian populations: The problem of separating human impacts from natural fluctuations. Science. 253:892-9.

Pounds, J.A., Bustamente, M. R., Coloma, L. A., Consuegra, J. A., Fogden, M. P., Foster, P.N., La Marca, E., Masters, K.L., Merino-Viteri, A., Puschendorf, R. and Ron, S.R., 2006. Widespread amphibian extinctions from epidemic disease driven by global warming. Nature. 439:161-67.

Oksanen, J., Blanchet, F.G., Kindt, R., Legendre, P., Minchin, P.R., O’Hara, R.B., Simpson, G.L., Solymos, P., Stevens, M.H.H. and Wagner, H., 2015. vegan: Community ecology package. 2015. R package version 3.3.0.

Radhakrishnan, B. P. 1993. Neogene uplift and geomorphic rejuvenation of the Indian Peninsula. Current Science. 64:11-12.

Reider, K.E., Carson, W.P. and Donnelly, M.A., 2013. Effects of collared peccary (Pecari tajacu) exclusion on leaf litter amphibians and reptiles in a Neotropical wet forest, Costa Rica. Biological Conservation. 163:90-98.

Robin, V. V., Katti, K., Purushotham, C, Sancheti, A., Sinha, A. 2011. Singing in the sky: Song variation in an endemic bird on the sky islands of southern India. Animal Behavior. 82:513-520.

Rocha, C.F.D., Sluys, M.V., Alves, M.A.S., Bergallo, H.G. and Vrcibradic, D., 2001. Estimates of forest floor litter frog communities: A comparison of two methods. Austral Ecology. 26:14-21.

Rodda, G.H., Campbell, E.W. and Fritts, T.H., 2001. A high validity census technique for herpetofaunal assemblages. Herpetological Review. 32:24-30.

Rodgers, W. A., and H. S. Panwar. 1988. Planning a protected area network in India. Volume I: The Report. Wildlife Institute of India. Dehradun.

Roelants, K., Gower, D.J., Wilkinson, M., Loader, S.P., Biju, S.D., Guillaume, K., Moriau, L. and Bossuyt, F., 2007. Global patterns of diversification in the history of modern amphibians. Proceedings of the National Academy of Sciences. 104:887-892. 
Ryan, T.J., Philippi, T., Leiden, Y.A., Dorcas, M.E., Wigley, T.B., and J. W. Gibbons. 2002. Monitoring herpetofauna in a managed forest landscape: Effects of habitat types and census techniques. Forest Ecology and Management. 167:83-90.

Scott, N. J., and B. D. Woodward. 1994. Surveys at breeding ponds. Pp. 118-125. In W. R. Heyer, M. A. Donnelly, R. W. McDiarmid, L. A. C. Hayek, and M. S. Foster (Eds.), Measuring and monitoring biological diversity: Standard methods for amphibians. Smithsonian Institution Press, Washington, D.C.

Storfer A., 2003. Amphibian declines: Future direction. Diversity and Distributions. 9:151-163.

Stuart, S.N., J.S. Chanson, N.A. Cox, B.E. Young, A.S.L. Rodrigues, D.L. Fischman, and R.W. Waller. 2004. Status and trends of amphibian declines and extinctions worldwide. Science. 306:783-1786.

Sung, Y.H., Karraker, N.E. and Hau, B.C., 2011. Evaluation of the effectiveness of three survey methods for sampling terrestrial herpetofauna in South China. Herpetological Conservation and Biology. 6:479-489.

Thomas, S. and Palmer, M., 2007. The montane grasslands of the Western Ghats, India: Community ecology and conservation. Community Ecology. 8:67-73.

Tocher, M. D., C. Gascon, and B. L. Zimmerman. 1997. Fragmentation effects on a central Amazonian frog community: A 10-year study. Pages 124-137 in W. F. Laurance and R. O. Bierregaard, editors. Tropical forest remnants: Ecology, management, and conservation of fragmented communities. University of Chicago Press, Chicago.

Vallan, D., 2000. Influence of forest fragmentation on amphibian diversity in the nature reserve of Amohitantely, highland Madagascar. Biological Conservation. 96:3143.

Vasudevan, K. and Dutta, S.K., 2000. A new species of Rhacophorus (Anura: Rhacophoridae) from the Western Ghats, India. Hamadryad Madras. 25:21-28.

Vasudevan, K., Kumar, A. and Chellaml, R., 2001. Structure and composition of rainforest floor amphibian communities in Kalakad Mundanthurai Tiger Reserve. Current Science. 80:406-412.

Vasudevan, K., Kumar, A. and Chellam, R., 2006. Species turnover: The case of stream amphibians of rainforests in the Western Ghats, southern India. Biodiversity and Conservation. 15:3515-3525.

Vonesh, J.R., Mitchell, J.C., Howell, K. and Crawford, A.J., 2009. Rapid assessments of amphibian diversity. Amphibian ecology and conservation: A handbook of techniques:263-280. 
von May, R. 2009. Amphibian community structure as a function of forest types in Southeastern Peru. Doctoral dissertation. Submitted to Graduate School, Florida International University.

Wake, D. B. and V. T. Vredenburg, 2008. Are we in the midst of the sixth mass extinction? A view from the world of amphibians. Procedings of the National Academy of Sciences. 105 (suppl. 1): 11466-11473.

Wanger, T. C., Iskandar, D.T., Motzke, I., Brook, B. W., Sodhi, N. S., Clough, Y., and T. Tscharntke. 2010. Effects of land-use change on community composition of tropical amphibians and reptiles in Sulawesi, Indonesia. Conservation Biology. 24:795-802.

Warshall, P. 1994. The Madrean Sky Island Archipelago: a planetary overview. In: Biodiversity and Management of the Madrean Archipelago: The Sky Islands of Southwestern United States and Northwestern Mexico (Ed. by F. L. DeBano, P. F. Folliott, A. OrtegaeRubio, G. J. Gottfried \& R. H. Hamre), Fort Collins, Colorado: United States Department of Agriculture. 6-18.

Watling, I. J., and M. A. Donnelly. 2006. Fragments as islands: A synthesis of faunal responses to habitat patchiness. Conservation Biology. 20:1016-1025.

Watling, J. I., Nowakowski, A. J., Donnelly, M. A., and J. L. Orrock. 2011. Metaanalysis reveals the importance of matrix composition for animals in fragmented habitat. Global Ecology and Biogeography. 20:209-217.

Whitfield, S. M., Bell, K. E., Philippi, T., Sasa, M., Bolaños, Chaves, F. G., Savage, J. M., and M. A. Donnelly. 2007. Amphibian and reptile declines over 35 years at La selva, Costa Rica. Proceedings of the National Academy of Sciences. 104: 8352-835.

Whitfield, S.M., Geerdes, E., Chacon, I., Ballestero Rodriguez, E., Jimenez, R.R., Donnelly, M.A. and Kerby, J.L., 2013. Infection and co-infection by the amphibian chytrid fungus and ranavirus in wild Costa Rican frogs. Diseases in Aquatic Organisms. 104: 173-178. 


\section{Tables}

\begin{tabular}{|c|c|c|c|c|c|c|c|}
\hline Serial No & English name & Species name & IUCN & Endemism & Eucalyptus & Shola & Tea \\
\hline \multicolumn{8}{|c|}{ I. ORDER ANURA } \\
\hline \multicolumn{8}{|c|}{ 1. Family BUFONIDAE (toads) } \\
\hline 1 & Common Indian Toad & Duttaphrynus melanostictus & Least Concern & India & Present & Present & Present \\
\hline \multicolumn{8}{|c|}{ 2. Family DICROGLOSSIDAE (fork tongued frogs) } \\
\hline 2 & Fejervarya sp & - & - & Western Ghats & Present & Present & Present \\
\hline \multicolumn{8}{|c|}{ 3. Family MICRIXALIDAE (dancing frogs) } \\
\hline 3 & Micrixalus sp & - & - & Kerala & Present & Present & Present \\
\hline 4 & Jerdon's Balloon Frog & Uperodon cf montanus & Near Threatened & Kerala & Present & Absent & Absent \\
\hline \multicolumn{8}{|c|}{ 4. Family NYCTIBATRACHIDAE (night frogs) } \\
\hline 5 & Nyctibatrachus & Nyctibatrachus poocha & Not Evaluated & Kerala & Absent & Present & Present \\
\hline \multicolumn{8}{|c|}{ 5. Family RANIXALIDAE (leaping frogs) } \\
\hline 6 & Indirana sp & - & - & Western Ghats & Present & Present & Present \\
\hline \multicolumn{8}{|c|}{ 6. Family RHACOPHORODAE (tree frogs) } \\
\hline 7 & Ghat Tree Frog & Ghatixalus asterops & Data Defficient & Kerala & Absent & Present & Present \\
\hline 8 & Beddome's Bush Frog & Raorchestes beddommii & Near Threatened & Kerala & Present & Absent & Present \\
\hline 9 & Green Eyed Bush Frog & Raorchestes chlorosomma & Critically Endangered & Kerala & Absent & Present & Absent \\
\hline 10 & Kodaikanal Bush Frog & Raorchestes dubois & Vulnerable & Western Ghats & Present & Present & Present \\
\hline 11 & Griet Bush Frog & Raorchestes griet & Critically Endangered & Kerala & Present & Absent & Present \\
\hline 12 & Anil's Bush Frog & Raorchestes anili & Least Concern & Western Ghats & Present & Present & Present \\
\hline 13 & Jayaram's Bush Frog & Raorchestes jayarami & Not Evaluated & Kerala & Absent & Absent & Present \\
\hline 14 & Kadalar Bush Frog & Raorchestes kadalarensis & Not Evaluated & Kerala & Present & Absent & Absent \\
\hline 15 & Munnar Bush Frog & Raorchestes munnarensis & Critically Endangered & Kerala & Present & Present & Present \\
\hline 16 & Malabar False Tree Frog & Rhacophorus pseudomalabaricus & Critically Endangered & Western Ghats & Absent & Present & Absent \\
\hline 17 & Giant Tree Frog & Ghatixalus magnus & Not Evaluated & Kerala & Absent & Present & Absent \\
\hline \multirow[t]{2}{*}{18} & Juvenile Raorchestes & - & - & India & Present & Present & Present \\
\hline & Totals & & & & 12 & 13 & 13 \\
\hline
\end{tabular}

Table 2.1. Complete list of species encountered from standard sampling methods from June to November, 2012. 


\begin{tabular}{|c|c|c|c|c|c|c|c|c|}
\hline & \multicolumn{3}{|c|}{ Shola } & \multicolumn{3}{c|}{ Tea } & \multicolumn{2}{c|}{ Eucalyptus } \\
\hline Transect type & $\begin{array}{c}\text { VES } \\
\text { num } \\
\text { ber }\end{array}$ & $\begin{array}{c}\text { ST } \\
\text { number }\end{array}$ & $\begin{array}{c}\text { FT } \\
\text { days }\end{array}$ & VES & ST & $\begin{array}{c}\text { FT } \\
\text { days }\end{array}$ & VES & $\begin{array}{c}\text { FT } \\
\text { days }\end{array}$ \\
\hline $\begin{array}{c}\text { No of } \\
\text { Transects/days of } \\
\text { trapping }\end{array}$ & 68 & 49 & 28 & 68 & 49 & 28 & 68 & 28 \\
\hline $\begin{array}{c}\text { Person hours/trap- } \\
\text { hours }\end{array}$ & 34 & 24.5 & 672 & 34 & 24.5 & 672 & 34 & 672 \\
\hline No of Species & 10 & 9 & 0 & 8 & 7 & 2 & 12 & 2 \\
\hline $\begin{array}{c}\text { Total number of } \\
\text { individuals }\end{array}$ & 131 & 106 & 0 & 62 & 67 & 2 & 37 & 2 \\
\hline $\begin{array}{c}\text { Species/person- } \\
\text { hours *100 }\end{array}$ & 29.4 & 77.6 & 0 & 23.5 & 28.6 & 0.3 & 35.3 & 0.3 \\
\hline $\begin{array}{c}\text { Individuals/perso } \\
\text { n hours }\end{array}$ & 3.853 & 4.327 & 0 & 1.824 & 2.735 & 0.003 & 1.088 & 0.00 \\
\hline
\end{tabular}

Table 2.2. Number of species, number of individual amphibians encountered, catch person-hour or trap-hour both by habitat, and method of sampling. (VES: Visual Encounter Survey; ST: Stream Transects; FT: Funnel Traps) 


\section{Figures}

\section{Number of amphibian species described annually in}

India

(2009-2015)

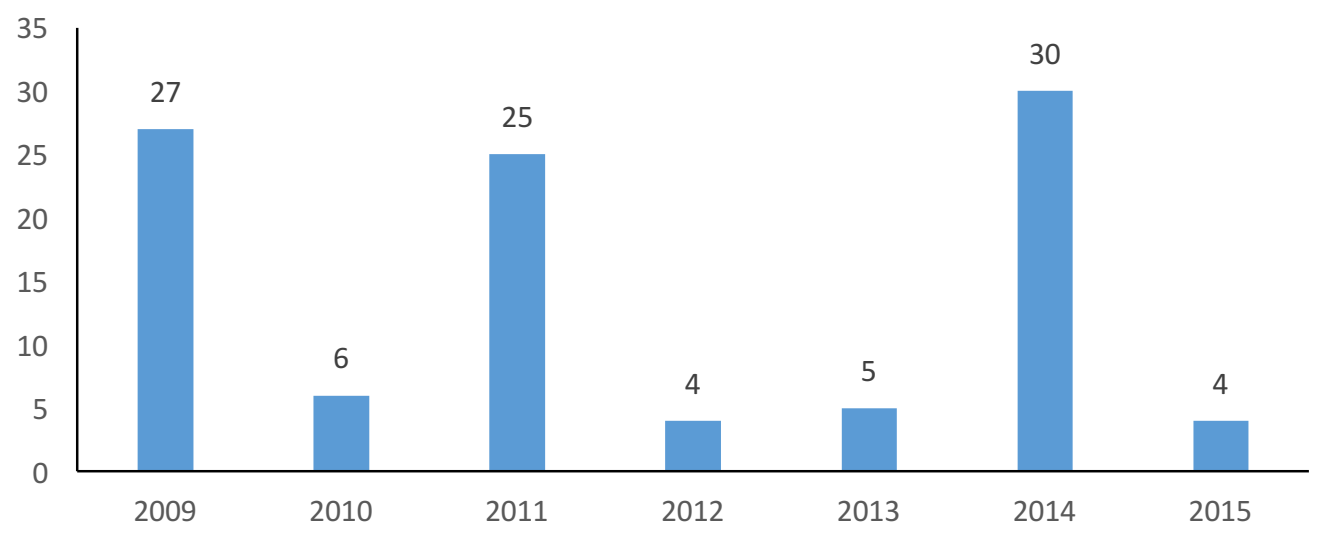

Figure 2.1. Number of amphibian species described in India from 2009 to 2015 (Frost 2016). 


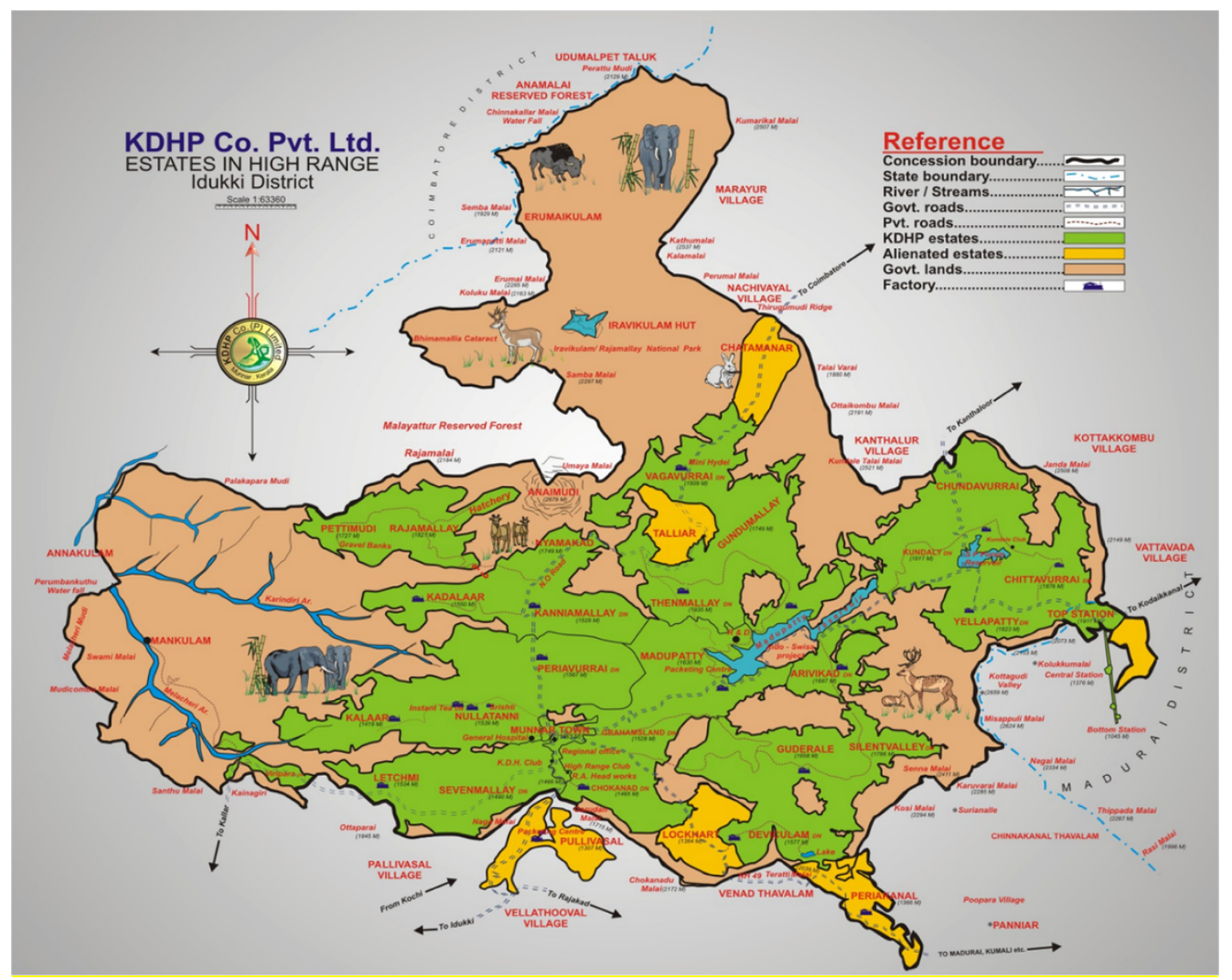

Figure 2.2. Map of KDHP Co Lt. (Kanan Devan Hills Private Cooperation Limited 2016). 


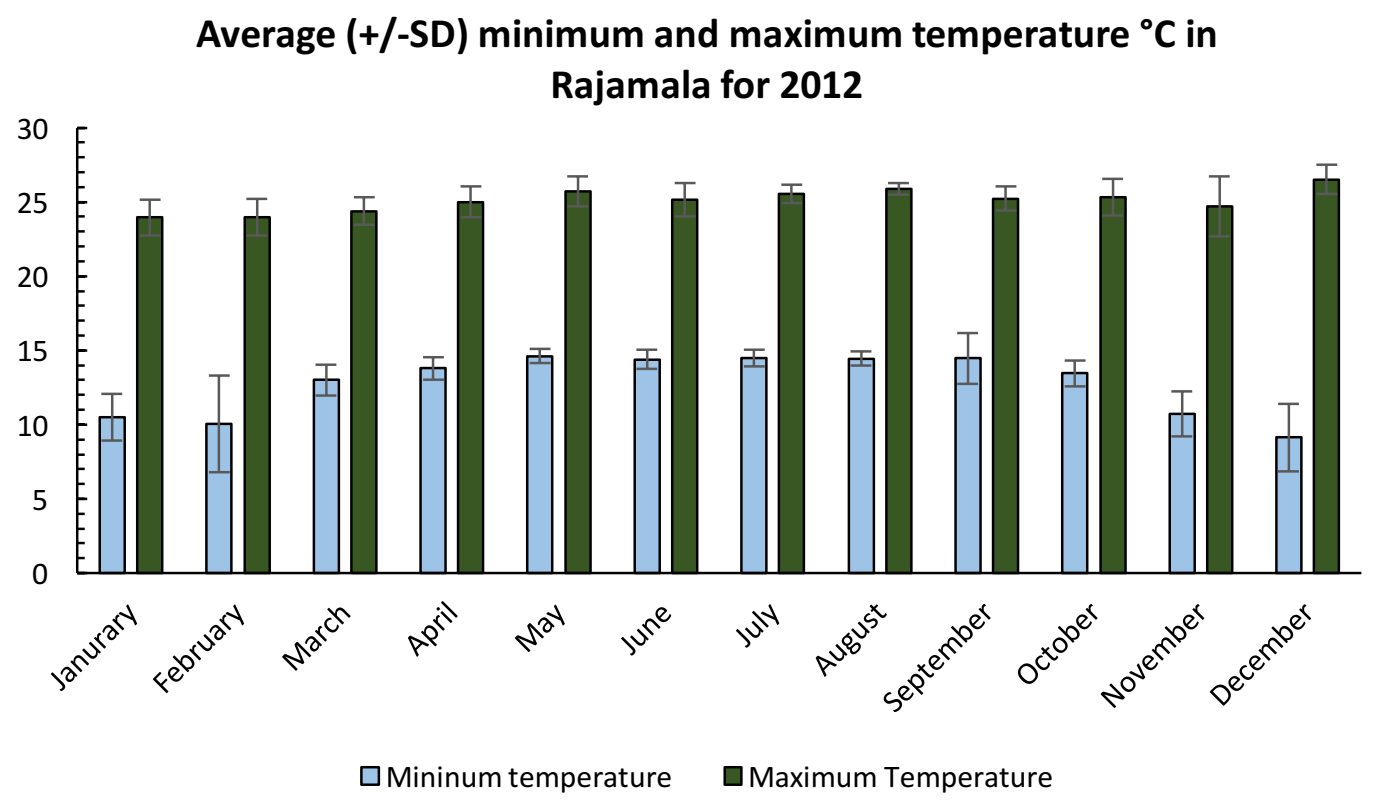

Figure 2.3. Monthly averages of minimum and maximum temperatures for year 2012 in Rajamala tea estate, Munnar, India. 


\section{Average Rainfall+SD(mm) and Relative humidity+SD(\%) for Rajamala in 2012}

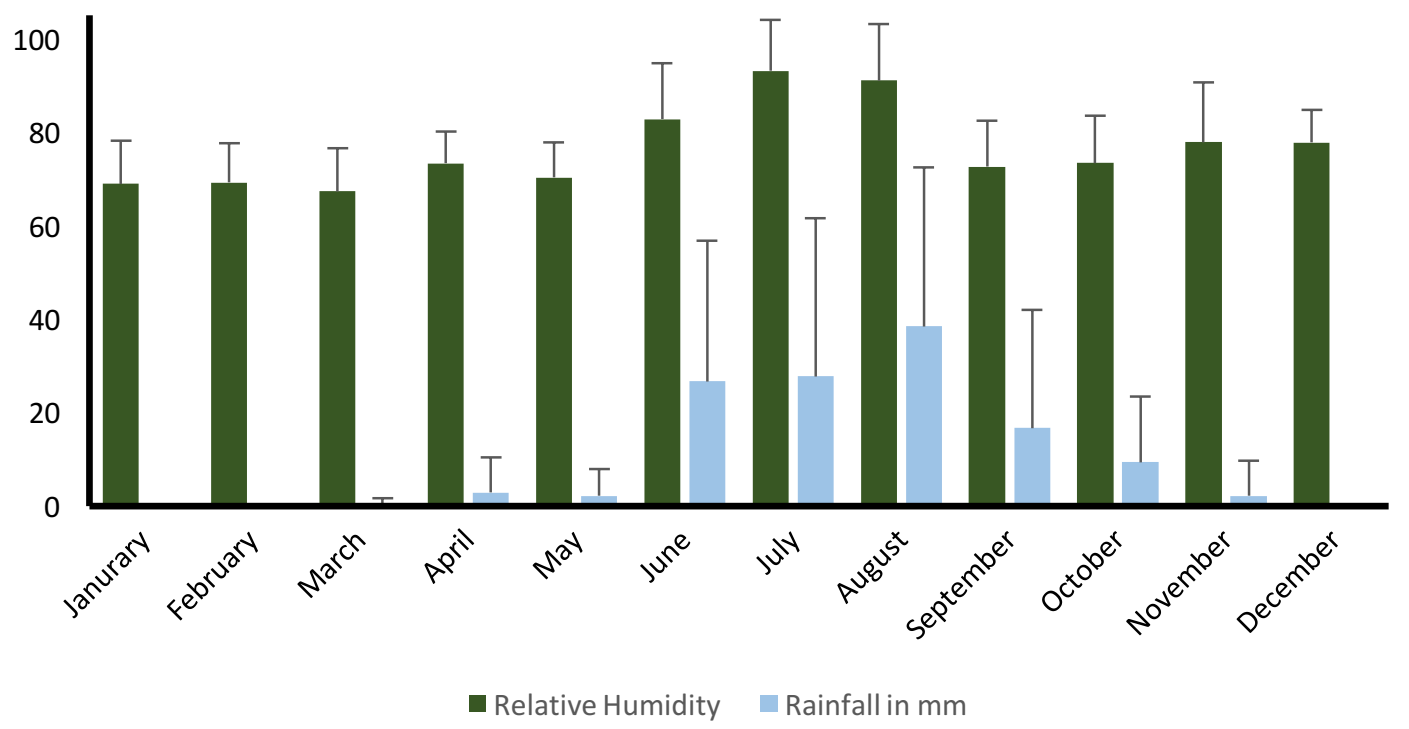

Figure 2.4. Monthly averages of Rainfall and humidity for year 2012 in Rajamala tea estate, Munnar, India. 


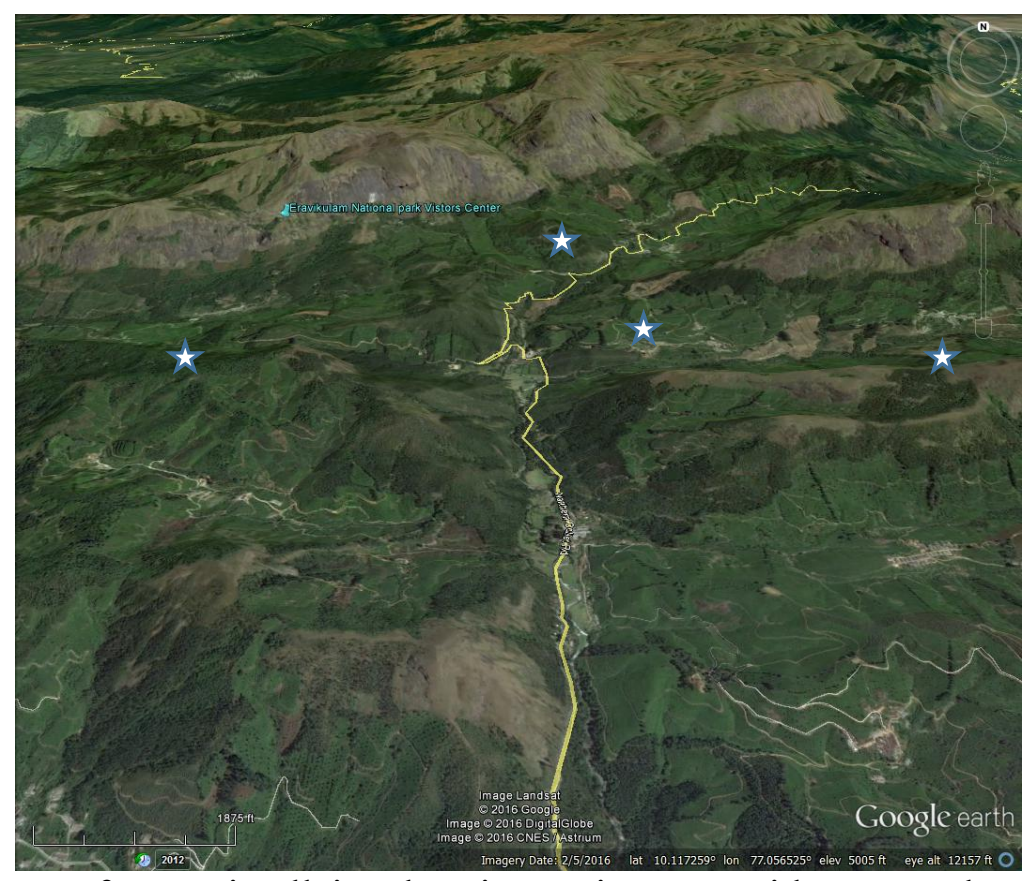

Figure 2.5. Map of Kannaimallai and Periavarrai estates with transect locations (Shola, tea, eucalyptus, and a stream) were setup. 


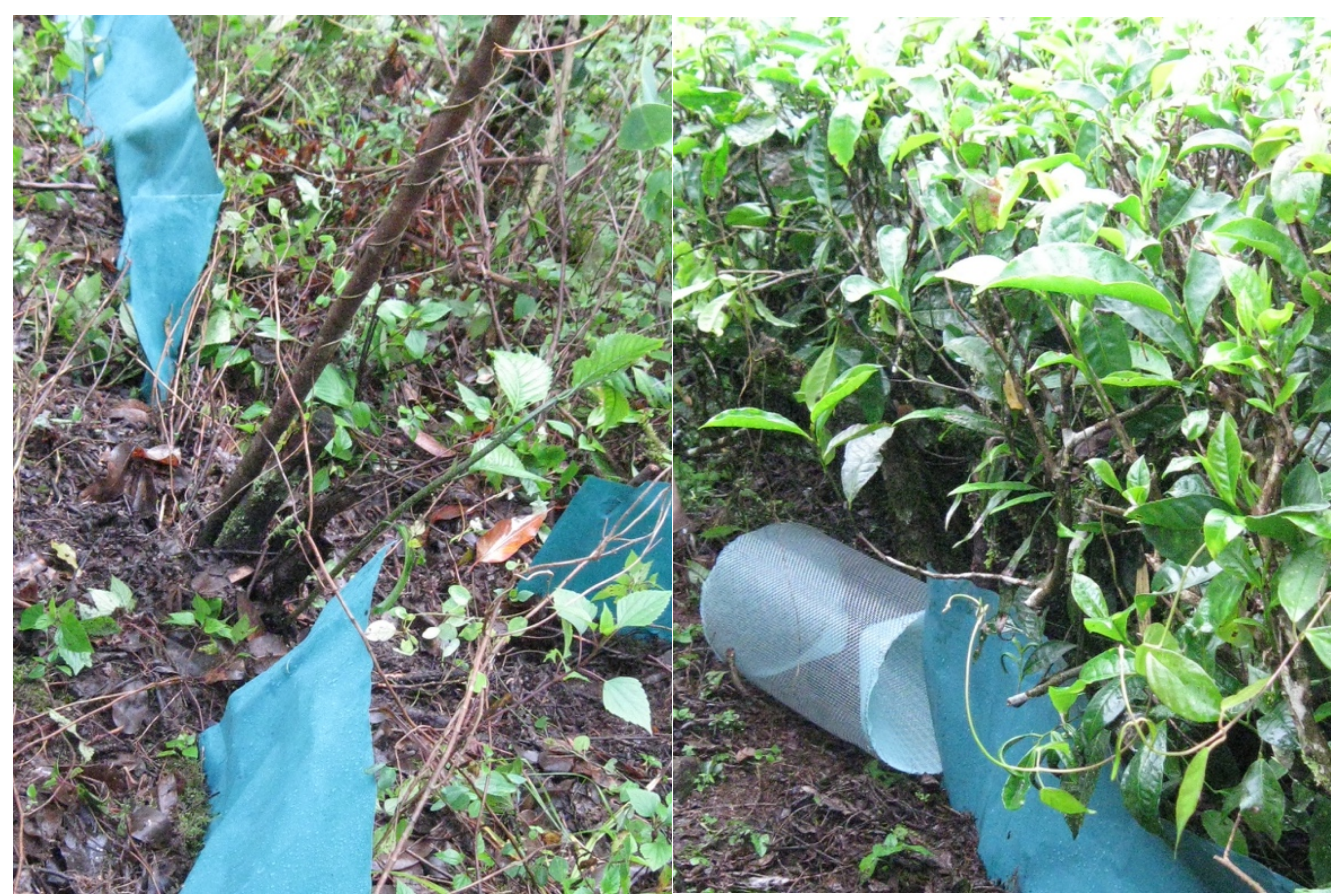

Figure 2.6. Drift fence with funnel trap image (Photos: Lilly Eluvathingal). 
Total number of individuals by habitat and month

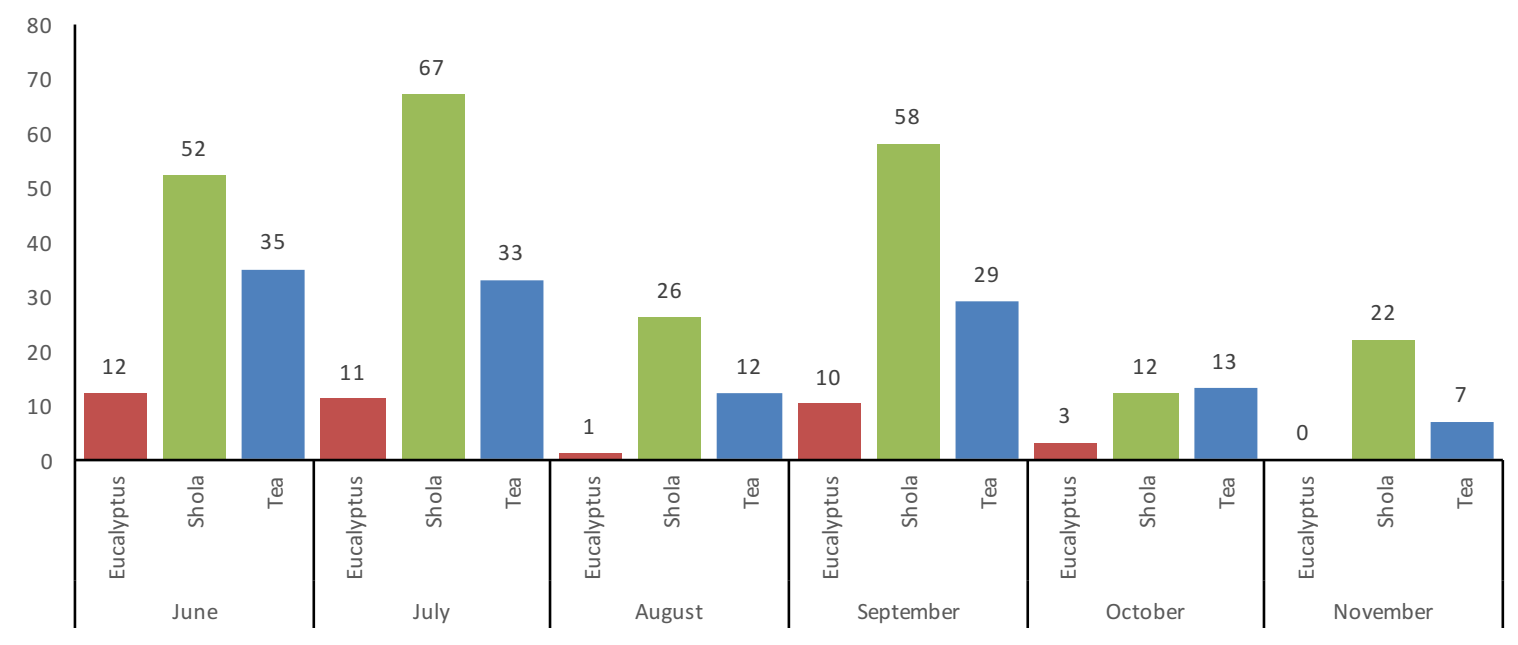

Figure 2.7. Number of individuals found in each of the habitats monthly from June to November, 2012. (Green: Shola; Red: Eucalyptus; Blue: Tea). 

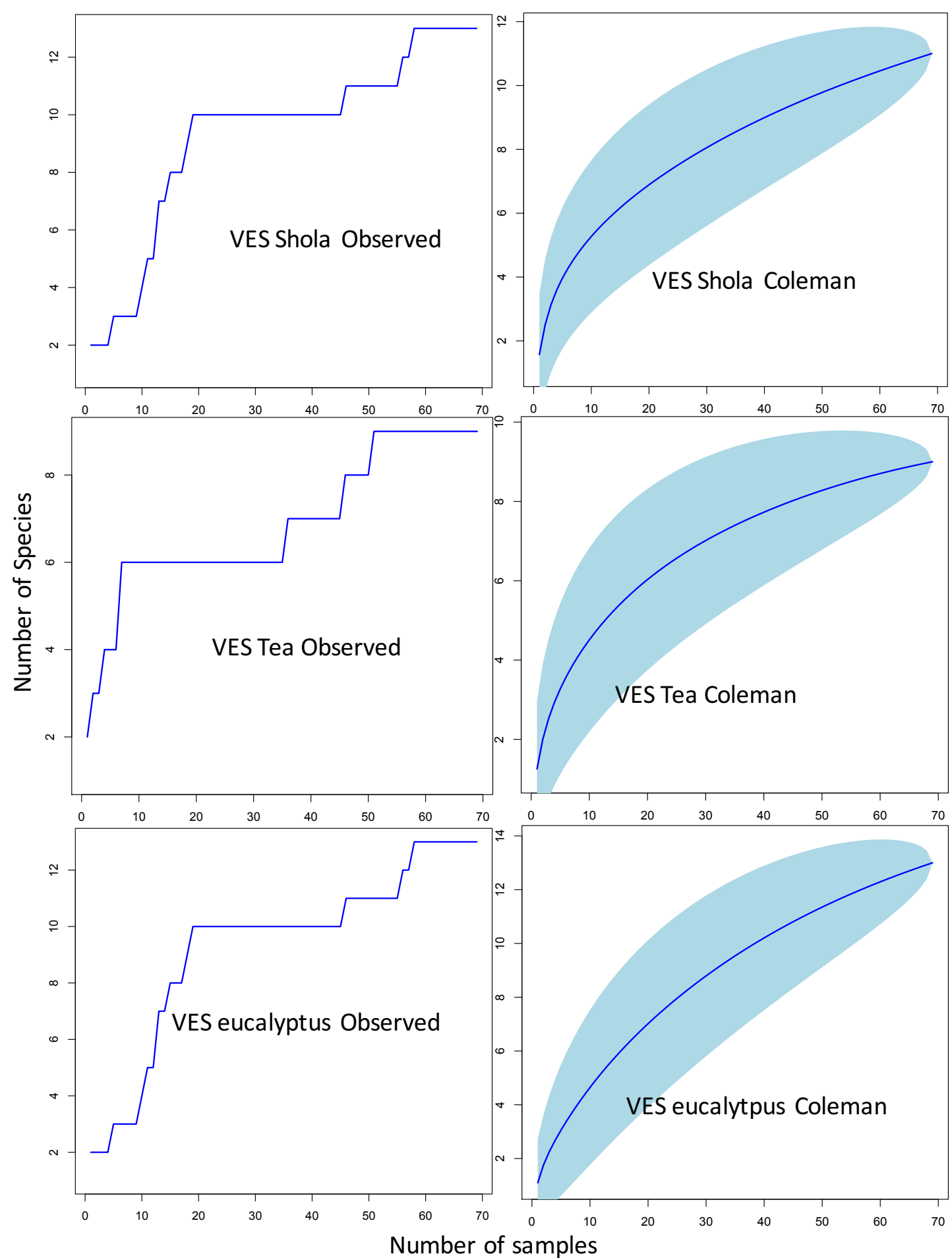

Figure 2.8. Observed and Coleman's species accumulation curves for 2012 data from Munnar. Samples using using visual encounter surveys and stream transects in each of the three habitats (Shola, tea, and eucalyptus). 


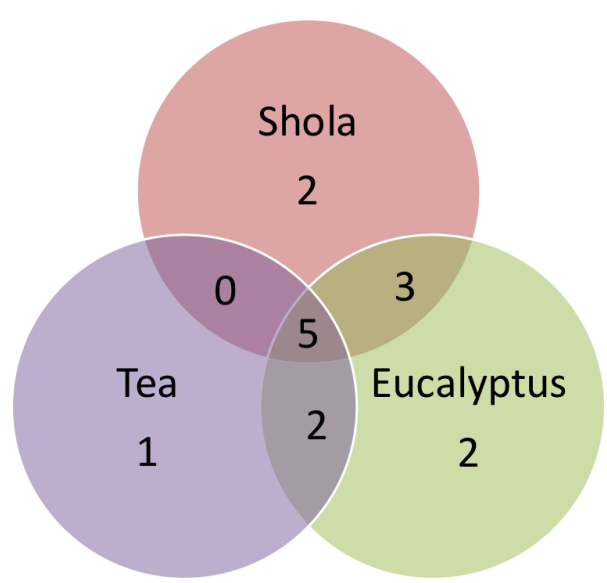

A

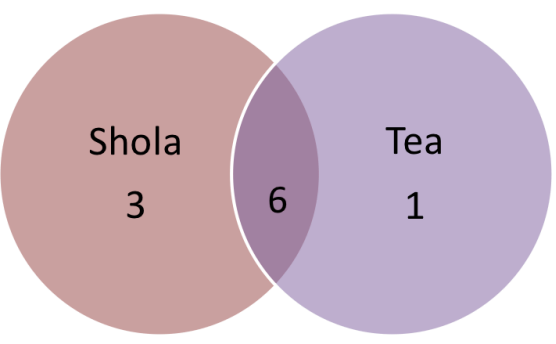

B

Figure 2.9. Number of exclusive species and number of overlapping species in different habitats types using Visual Encounter Surveys (A) and stream transects (B). 


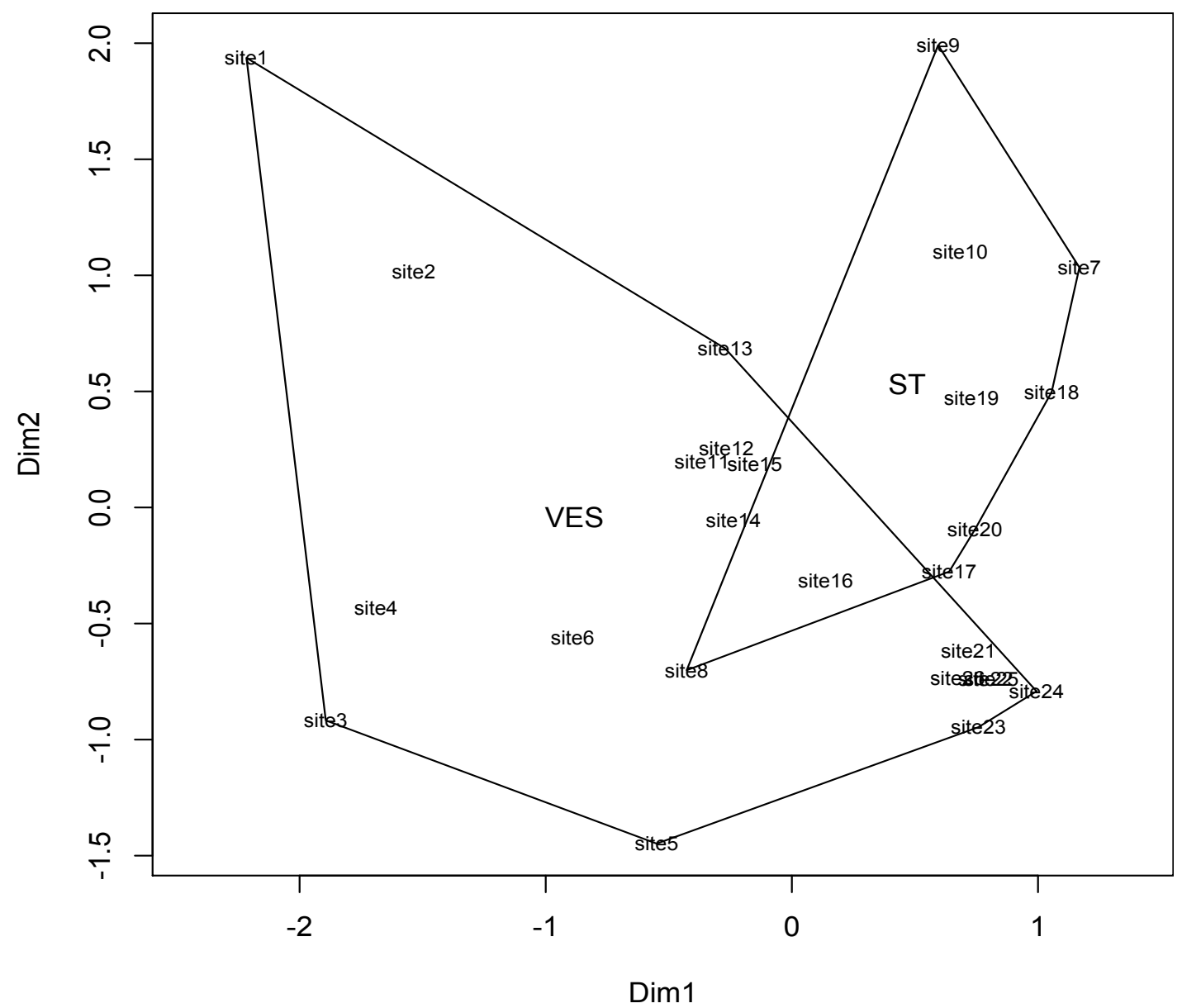

Figure 2.10. Meta nMDS plot of pooled transect data with polygons drawn around transects using the same standard methods: Visual Encounter Surveys and Stream Transects (VES and ST; Stress: 0.2214079). 


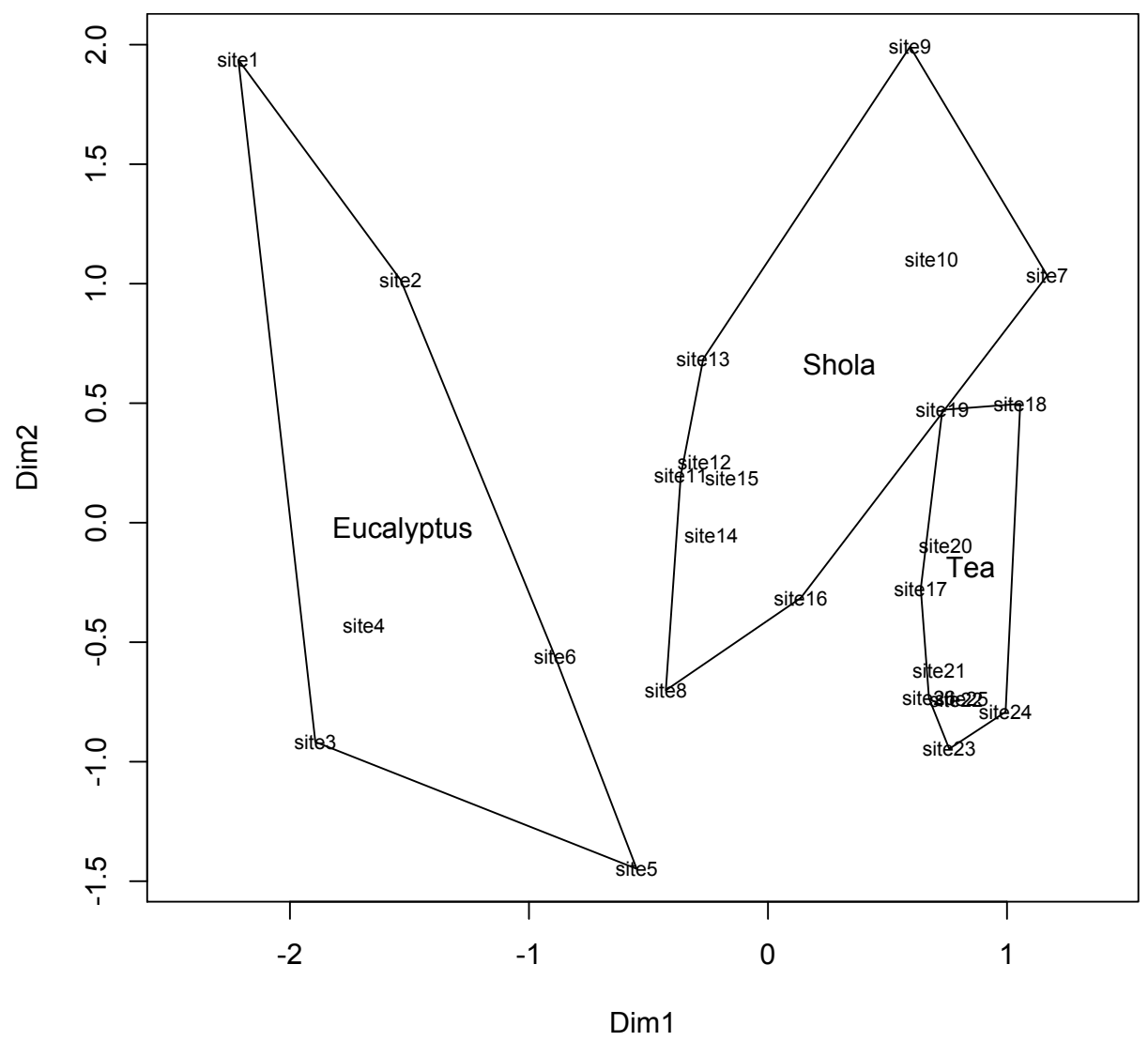

Figure 2.11. Meta nMDS plot of pooled transect data with polygons drawn around transects in conducted in the same habitats (Tea, Shola, and Eucalyptus; Stress: $0.2214079)$. 


\title{
IV. CHAPTER 3
}

Patterns of Anuran Community Structure in a Tea Plantation Landscape

\begin{abstract}
\end{abstract}
Global amphibian declines have been reported since the late 1980s and some of the major drivers of these declines are reported to be habitat loss and the emergence of infectious diseases like chytrid. While amphibians are declining globally, new species of amphibians continue to be described from countries like India. It is critical to study amphibian species diversity in poorly studied regions of the world before we lose the habitat that supports such species. The Western Ghats and Sri Lanka Biodiversity Hotspot is a zone of high endemism for amphibians, and is a region that is being affected by increasing human population pressure. We hypothesized that the anuran community composition would differ across four sites in the tea plantations in Munnar, India, as well as, across three habitat types in the landscape. A total of 648 visual encounter surveys and 216 stream surveys were conducted between April to December, 2013 and May to December, 2014. In 2013, 724 individuals were encountered on the VES transects; in 2014, 632 individuals were encountered using VES transects. In case of stream transects, 536 and 600, individuals were encountered in 2013 and 2014, respectively. There was no difference in community structure between 2013 and 2014, and the data from the two years were analyzed together to describe how the anuran assemblages varied across three main habitats in the tea plantation setting: tea, eucalyptus, and remnant patches of shola forests. A total of 14 species were encountered in both years. I used multivariate statistical methods to determine how anuran communities were organized in the area. 
Anuran communities were similar at two of the sites, Madupetty, and Silent Valley. The community of anurans in stream transects differed slightly from the anuran community in upland transects with three species driving the difference. The present study creates baseline data of anuran communities in the tea plantation landscape near Munnar in the southern Western Ghats.

Key words

anuran, diversity, eucalyptus, habitat, plantation, shola, tea

Introduction

Amphibian declines have been reported by scientists all over the world since the late 1980s and some driving factors of these declines have been identified as loss and fragmentation of habitat, pollution and increase in pesticide use, chytrid fungus infection and other diseases, ill-planned dam and water management systems, ultraviolet- $\beta$ radiation, and the introduction of alien species (Alford and Richards 1999; Bickford et al. 2010; Blaustein and Kiesecker 2002; Cushman 2006; Grant et al. 2016; Whitfield et al. 2016). The modification of the earth's surface by humans has contributed to severe biodiversity loss around the globe (Fischer and Lindenmayer 2007; Vitousek et al. 1997). According to the FAO (2011), approximately 15 million ha of forests are destroyed every year, and a major part of the deforestation occurs in the tropics where the richest biodiversity is located. According to the International Union for Conservation of Nature and Natural Resources (IUCN) over $41 \%$ of global amphibian diversity is threatened, and 
this percentage does not account for species that are data deficient or those that have not been assessed for their threat status (Hoffmann et al. 2010). Of the many predicted drivers of amphibian declines, the fungus Batrachochytrium dendrobatidis $(B d)$ and its salamander counterpart Batrachochytrium salamandrivorans (Bsal) have been identified as being responsible for a large number of mass amphibian die-offs in Australia, and Central America, and northern Europe (Berger et al. 1999; Kolby and Daszak 2016; Martel et al. 2013; Pechmann et al. 1991; Whitfield et al. 2016). Species of amphibians vary in their susceptibility to $B d$ and the fungus varies in virulence, and in conjunction with warming global temperatures, the stressor will affect species differently (RollinsSmith, 2016).

Even though amphibian declines are occurring globally, there are several regions that are not represented by detailed studies. The anurans of the Western Ghats in southern India, for example, have not been subject to ecological study. In the last 30 years there has been a spike in the number of anuran species described from the Western Ghats Biodiversity Hotspot (Frost 2016). The Western Ghats is an area which has conservation need as it faces increasing anthropological stresses from from a growing population. The area is home to many amphibian species, and several are critically endangered and locally endemic (Bossuyt et al. 2004; Myers et al. 2000; Figure 3.1). To qualify as a "biodiversity hotspot", a region must meet two strict criteria: (1) it must contain at least 1,500 species of endemic vascular plants ( $>0.5$ percent of the world's total) and (2) the region must have lost at least 70 percent of its original habitat because of some external pressure (Conservation International 2012). The Western Ghats region in the Western 
Ghats and Sri Lanka Biodiversity Hotspot (area 18 in Figure 3.1), is home to 198 amphibians, $80 \%$ of which are endemic (Frost 2016; Table. 3.1). High endemism in the Western Ghats-Sri Lanka region has been attributed typically to the geographic history of long-term isolation of the mountain chain (Bossuyt et al. 2004; Gunawardene et al. 2007; Van Bocxlaer et al. 2009).

The Western Ghats are a part of the Malabar biogeographic region and form a continuous chain of small to medium-sized mountain ranges running nearly $1600 \mathrm{~km}$ along the western coast of Southern India, from 8 to 21 N latitude (Rodgers and Panwar 1988; Figure 3.2). The mountains of the Western Ghats generally vary between 600 and 1000 $\mathrm{m}$. However, there are several mountain peaks that extend between 1000-2600 m between 8 and $13^{\circ} \mathrm{N}$ and 18 and $19^{\circ} \mathrm{N}$ (Daniels 1992). The only break in the mountain range occurs in the Palghat Gap (Figure 3.2). The Palghat Gap ( 10 $35^{\circ} \mathrm{N}$ and $\left.10^{\circ} 50^{\prime} \mathrm{N}\right)$ is a $35 \mathrm{~km}$ wide, low mountain pass (Bossuyt 2002; Figure 3.2). The annual $0.44 \%$ deforestation rate in the Western Ghats is a strong motivation to study amphibian community structures in these regions (Lo Seen et al. 2010). In the case of the amphibians of the Western Ghats, in spite of these anthropogenic threats, the rate of discovery of new species is still an increasing function (Figure 3.3). Previous studies show that the amphibian diversity can vary greatly between hills (separated by $<100 \mathrm{~km}$ ) in the same mountain range (Daniels 1992). Thus, the isolated hill ranges of the Western Ghats act as spatially isolated islands supporting high levels of endemism (Bossuyt et al. 2004; Krishnamurthy 2003). A large phylogenetic study using individuals of the Bush Frog genus, Raorchestes, by Vijaykumar et al. (2016) showed that geographical isolation 
and events of exchange of genes across the Palghat gap, climate-driven isolation because of a Quaternary glaciation event, and divergence of species along the elevation gradients of the Western Ghats are all responsible for high species richness of the genus. The vegetation of the Western Ghats varies from dry deciduous and deciduous rain forests, to montane and evergreen forests, with short stunted forests also called 'sholas' and grasslands at high elevations (Rodgers and Panwar 1988). Very little is known about the effects of habitat differences on community structure of amphibians in India. It can be expected that the amphibian fauna of the Western Ghats is influenced by the variation in forest types, habitat diversity, altitude, latitude, and that overall diversity is in part dictated by high beta diversity across habitats (von May 2009).

Replacing natural vegetation with the cultivation of crops has been occuring since humans adopted a sedentary lifestyle. The modification of the earth's surface by humans has contributed to severe biodiversity loss around the globe (Fischer and Lindenmayer 2007; Vitousek et al. 1997). According to the FAO (2011), approximately 15 million ha of forests are destroyed every year, and a major part of the deforestation occurs in the tropics where the richest biodiversity is located. New plantation areas are being established at the rate 4.5 million ha per year and occurs primarily in Asia and South America (FAO 2011). With an increasing population size comes an increase in the demand for resources, food, timber, oil, coffee, and other resources. These demands are not going to disappear or decrease in the future. In light of the increases in land area being converted to plantations, it becomes extremely important to understand the effect that plantations have on native fauna and flora (Fischer and Lindenmayer 2007; Gardner 
et al. 2007a, 2007b). Conversion of naturally forested land into monocultures has an effect on the quality of the habitat that is available for the native flora and fauna (Fischer and Lindenmayer 2007; Vitousek et al. 1997). Some of the major concerns that arise as a result of reduction in forest cover are habitat loss and fragmentation, which most people view as the same (Fahrig 2003). Habitat loss deals with reduction in total habitat size and fragmentation with the problem of small patches (Fahrig 2003). The formation of small patches leads to many effects driven by factors that change at the edges of the patches and vary according to the connectivity of the patches themselves. The effects of the matrix surrounding the habitat patch must also be considered (Watling et al. 2011 and Nowakowski et al. 2016) There are several detailed reviews that look at the effects of fragmentation and edge effects (Ewers and Didham 2006; Saunder et al. 1991).

Plantations require heavy inputs of agro-chemicals like pesticides and fertilizers, which affect the region of the plantation directly and neighboring forests indirectly through runoff (Chen et al. 2009). Constant agro-chemical modifications of the soil can change the characteristics of the land holding such that it cannot recover even if native forest species are planted again (Chen et al. 2009). In contrast, the addition of nitrogen (through fertilizer application) increased the species evenness but did not cause a change in beetle diversity in tea plantations (Chen et al. 2009). The coverage of secondary forests has increased in the tropics (Wright 2005). In addition to acerage covered by plantations, other anthropogenic changes accompany development to support farming like roads and access routes which affects the connectivity of remnant forest patches. Loss of natural habitats to plantations cannot be prevented however it is possible to try and reduce 
damage to the natural environment (Bali et al. 2007; Gardner et al 2007b; Wanger et al. 2010). It is important to study biodiversity within plantations to determine if they harbor diversity, or if they are just "green deserts" (Bremer and Farley 2010). Some studies show that the extent of damage by plantations depends on the type of ecosystem that was cleared to make way for the plantation (Bremer and Farley 2010; Cassano et al. 2009; Gardner et al. 2007b). Gardner et al. (2007b) conducted studies on the effect of primary, secondary, and plantation forests on herpetofaunal diversity in the Brazilian Amazon and the results suggest that secondary forests had approximately $66 \%$ of the natural amphibian community from the landscape, while plantations supported only five generalist amphibian species.

Large plots of lands in the mid and high elevations of the southern Western Ghats have been under cultivation for plantation crops like tea, coffee, rubber, and other spices and cash crops since the late 1870s. Herein, I describe the anuran community in a landscape dominated by tea plantations naturally interspersed with small patches of forests creating a classic fragmented landscape (Gardner et al. 2007a; Watling and Donnelly 2006). Watling et al. (2011) found that the quality of the matrix has a large impact on species diversity because some matrix types cannot be crossed. Tea is a tree which grows in the tropics and sub tropics, and all commercial tea is produced from a single species, Camellia sinensis (Shalleck, 1972). Tea plants are regularly sprayed with chemicals to keep fungi and other diseases at bay (Table. 3.2). The European Union (EU) regulations require that the maximum limit of chemicals sprayed not exceed those in Table 3.2 and that spraying be restricted to dry months of the year (Table. 3.2; Daniels 2003; European 
Union MRL, 2015). Personal observations and prior research showed that restricted spraying is not always practiced on the ground, because the reality of tea production is different from theoretical tea production (Daniels, 1991; Daniels, 2003). In the only study (six days in the wet season and four days in the dry season) of amphibians in tea, Daniels (2003) reported 13 species of amphibians from a single tea estate. The species list included both prolonged and explosive-breeding taxa (Table. 3.3). In a preliminary study, Hegde (2012) reported 20 species of frogs in an Arecanut plantation in northern Karnataka, India. The fact that such short studies revealed the presence of anurans suggests that plantation landscapes provide habitat for frogs.

My project was designed to determine how the community composition, abundance, and habitat use of the anurans in tea plantations varied among distinct sites and years, in the state of Kerala in the southern Western Ghats of India. I used nocturnal VES method in three upland habitat components of the tea landscape: Shola forest patches, eucalyptus patches, tea fields, and along steams. Upland permanent transects ( $25 \mathrm{~m}$ long) were used during the two years in four sites. Each habitat type had three transects $(3 * 3 * 4=36$ upland transects). The stream transects were $50 \mathrm{~m}$ long and there were three independent streams at each site. These four sites were picked because of the presence of weather stations that were already in operation and maintained by the tea planation management. The sampling was conducted from April to December, 2013 and May to December, 2014, in each of the sites where I sampled, because the climatic patterns in the region are predictable. I hypothesized that the anuran communities would be similar between the two years (2013 and 2014). I expected that sites closest to each other would have more 
similar communities of anurans than sites that are further apart. All the sites are separated by less than $111 \mathrm{~km}$ apart and according to Daniels (1992), these sites should have similar composition. Given that so little is known about the frogs in the region, I hypothesize that the anuran species composition and abundance will vary across the sites and that species richness will be highest in the sholas. I predict that the abundance and richness of indiviuals will be greater during the Southwest monsoons compared to the Northeast monsoons. I will compare the data obtained from the weather stations at each estate group. Because tea is consumed in India and around the world, and its popularity continues to increase, my study provides important background information regarding anuran diversity patterns in an actively managed agro-ecosystem nested within a biodiversity hotspot and could serve as a basis for future study of the biodiversity of the plantation ecosystem.

Study Area

I conducted the surveys in two years (2013 and 2014) in the Kanan Devan Hills Tea Plantation Company Private Limited (henceforth KDHP; $10^{\circ} \mathrm{N}$ and $77^{\circ} \mathrm{E}$; Figure 3.4 and Figure 3.5) located in Munnar, in Idukki District, Kerala, in the southern Western Ghats. Kerala accounts for $8.5 \%$ of the total tea production of India (Tea Board of India, 2016). Munnar, located in the Devikulam Forest Division, is a large tea producing area in Kerala (Figure 3.4). Munnar is located in the Anamallai mountain range in the Munnar Forest Division. More than $106 \mathrm{~km}^{2}$ of reserve forest is interspersed in a matrix of tea fields, eucalyptus patches, and communities of tea plantation workers. The landscape includes 
undulating hills and ridges between $900-2600 \mathrm{~m}$ asl, that run in the northeast to the northwest direction. Though present in the tropical belt, the climate in Munnar is temperate because of elevation. Munnar receives $80 \%$ of the annual rainfall in June and July from the Southwest monsoon and the remaining 20\% during the Northeast monsoons from October to late November (Thomas and Palmer, 2007; Figure 3.7). The minimum temperature in $2013-2014$ was $0^{\circ} \mathrm{C}$ and the maximum temperature was $29^{\circ} \mathrm{C}$ (Figure 3.83.11). The relative humidity during the monsoon season is over $80 \%$. The Idukki district, of Kerala, supports wet evergreen, semi-evergreen, moist deciduous, dry deciduous, broad-leaved hill forest, montane wet temperate forest and grasslands (Champion and Seth 1968; Thomas and Palmer 2007).

Tea plantations were established in 1877, after John Daniel Munro leased the land from the Poonjar Chief without any time stipulation (KDHP Management Plan 2002). The Kanan Devan Hills Tea Plantation Cooperation Private Limited was established in 2005 and is a $238 \mathrm{~km}^{2}$ holding, $98 \mathrm{~km}^{2}$ of which is under tea cultivation (Figure 3.4). Almost $80 \mathrm{~km}^{2}$ of this area has been converted into fuel wood (eucalyptus) stands which are harvested in cycles of seven years. Eucalyptus is used for drying tea as well as, by members of the local community as a source of fuel for cooking. The 27 tea estates are now aggregated into seven estate groups for ease of management. The other major habitat types in this area in addition to tea and eucalyptus, are remnant patches of shola forest, and the lands included in the Eravikulam National Park (Thomas and Palmer, 2007). The other plantations in the area are owned by American Direct Tea Trading Co. Ltd, Thalayar Tea, The Malayalam Plantation Ltd, and some private planters. 
Tea bushes are maintained as shrubs $(\sim 1.5 \mathrm{~m}$ tall $)$, and are planted half a meter apart (Shalleck, 1972). The remnant shola forests patches usually grow in steep mountainous valleys that are protected from the wind. Shola trees are shorter than $10 \mathrm{~m}$, and form patches of stunted forest. The shola forests include trees from the families, Lauraceae, Rubiaceae, Symplocacaeae, Myrtaceae, Myrsinaceae and Oleaceae (Bunyan et al. 2012; Champion and Seth 1968). The forest patches are usually seen above $1500 \mathrm{~m}$ in elevation. The branches of these trees are covered in mosses and epiphytes supported by the high relative humidity (Thomas and Palmer, 2007).

The sholas and grasslands of the high elevations in Munnar were cleared to establish the tea plantations. At elevations above $1800 \mathrm{~m}$ most of the land not covered by rock faces is covered with grass. My study was conducted in the three main habitat types (tea, shola, and eucalyptus) replicated in four different tea plantations sites to compare the diversity and abundance of anurans assemblages.

\section{Methods}

Sampling was conducted between May and November, of 2013 and between May and December, of 2014. Four sites were selected for the surveys. Site 1: Vaguvarrai, Site 2: Rajamallay and Pettimudi, Site 3: Madupetty and Thenmala, and Site 4: Silent Valley (Figure 3.5). These sites support small remnant patches of forests (sholas), and weather stations were located in each site. Each weather station collected daily precipitation, 
humidity, and temperature data. In each of the sites, three replicate transects were established $(3 * 3 * 4=36$ total upland transects). Each transect was situated in a belt between 1500 to $2000 \mathrm{~m}$, to avoid potential effects of elevation on the anuran community because of the high turnover associated with the elevation described for the region (Daniels 1992). In each estate group, three shola patches which were accessible and of sizes less than 3 hectares were surveyed and selected for the transects. These shola patches were surrounded by a matrix of tea, eucalyptus, or a mix of both.

Nocturnal time-constrained Visual Encounter Surveys (VES) were used in the three upland habitats. For the VES, I set up $25 \mathrm{~m}$ transects in each of the habitat types. The transects were $25 \mathrm{~m}$ long, because the habitat is too heterogeneous to accommodate standard $50 \mathrm{~m}$ transects. Transects were started at least $5 \mathrm{~m}$ away from the trail or the edge of the habitat to avoid trail effects (von May and Donnelly 2009). Nocturnal sampling was conducted from $1900 \mathrm{hrs}$ to $2300 \mathrm{hrs}$ by two observers using head lamps (Doan 2003; Donnelly et al. 2005). The same two observers conducted sampling both years. Observer effect was minimized by randomization of the order of the observer who started the transect and the order in which the transects were sampled each night. In each estate, all three habitat types and the stream transects were sampled on the same night (between 19:30hrs and 23:00hrs) to avoid temporal effects on frog encounters. On nights when sampling was interrupted by heavy rain or wildlife encounters (e.g., elephant or gaur encounters), sampling was discontinued and then repeated the next day. All individuals located within $1 \mathrm{~m}$ of either side of the transect and up to $2 \mathrm{~m}$ in height were captured and put into zip lock bags (new zip lock bags were used at each transect). The 
distance of measurement of the transect was maintained consistently by using plastic poles which were marked at the $1 \mathrm{~m}$ length. At the end of the transect, the captured individuals were identified, measured and photographed and then released in the middle of the transect in each case. Animals were captured by hand or by small aquarium net to ensure that the animal was exposed to minimal stress. Standard animals handling protocols were approved by Florida International University's Institutional Animal Care and Use Committee (IACUC: 13-034-CR01-200222). Upon capture frogs were identified to species or morphospecies, measured (snout-to-vent length in $\mathrm{mm}$ ) with a plastic field calipers (SPI Plastic Dial Caliper Model 31-415-3), weighed by placing the animal in a clean plastic bag and measuring mass with a Pesola scale $\left(\right.$ Pesola ${ }^{\circledR}$ LightLine Spring Scales, 10g and 30g) to the nearest mg and then released (Crump and Scott. 1994). On averge, an individual was handelled for $2 \mathrm{~min}$. Three $50 \mathrm{~m}$ long stream transects $(3 * 4=12$ transects of 50m each) were established within shola patches in each of the estate groups. The stream transects were $50 \mathrm{~m}$ long, as it was possible to find accessible stretches that met all the criteria. Environmental variables (precipitation, relative humidity and temperature) were obtained from permanent weather stations maintained by the tea estate management and are described graphically herein.

\section{Analysis}

Meteorological data obtained from the permanent weather stations were summarized by month). I use the community ecology package vegan from the open source software package R version 3.3.0 to calculate a Bray Curtis dissimilarity matrix of the data from transects conducted in each year (Oksanen et al. 2015). To test for similarity of anuran 
community structure I used non-metric Multidimensional Scaling (nMDS) plots to visualize the patterns of community structure of the data. The software program $\mathrm{R}$ was used to generate the Meta-nMDS plots which produce the most stable result from 20 nMDS iterations using the package vegan (Oksanen et al. 2015). I used the analysis of similarity (ANOSIM) to test the statisctical significane of clustering seen in the MetanMDS plots.

A Meta-nonMetric Dimensional Scaling plot (meta nMDS) was constructed and minimum convex polygons were constructed around sites from the two years. To test the hypothesis that the assemblages did not differ between 2013 and 2014, I ran an analysis of similarity (ANOSIM) between the data obtained in each year. The data show no difference between years, so I used the community ecology package vegan from the open source software package R version 3.3.0 to calculate a Bray Curtis dissimilarity matrix of all the data from transects conducted in both years (Oksanen et al. 2015) to test my hypotheses. A Meta-nonMetric Dimensional Scaling plot (meta nMDS) was constructed and minimum convex polygons were constructed around sites using the estate groups, to test the hypothesis that there was no difference in community structure among the sites. I used a ANOSIM analysis to see if there was a significant effect of site on community structure. Similarity ellipses were also constructed around the transect type and the three habitat types. I also used ANOSIM to find out if the communities differed in their use of habitat types. The number of species encountered each month, in both the years of sampling, were summarized to look for patterns in phenology of the species encountered. For both VES and stream transects, the number of species encountered per unit time 
taken for sampling each transect was used to calculate person effort in each habitat type to show how the encounter rate varied between habitats. The same calculations were done for each site to see if there was difference in the encounter rates of species and average number of individual depending on the site being sampled.

Results

I sampled 324 upland Visual Encounter Surveys transects, and 108 stream transects each year. A total of 648 upland transects and 216 stream transects were completed, such that each transect was sampled nine times each year. In 2013, 724 individuals were encountered on the VES upland transects. In 2014, 632 individuals were encountered along upland VES transects. In the case of stream transects, 536 frogs were encountered in 2013, and I encountered 600 individuals in 2014. I used the total species abundance data for each transect to run ordination plots. The ANOSIM showed no effect of year on the frog community $\left(\mathrm{R}^{2}=0.01781 ; \mathrm{p}<0.1138\right)$, and data from 2013 and 2014 were analyzed together (Figure 3.6).

All four sites received the highest average rainfall in the month of June in the year 2013. In 2014, the average rainfall across the sites was highest in July (Figure 3.7). The rainfall at Rajamallai and Pettimudi was greatest, while the Silent Valley was the driest site in both years. Nyctibatrchus poocha was not encountered in the upland transects in 2013, while Duttaphrynus microtympanus was not encountered in the upland transects in 2014. Thus, in each year 13 species were encountered in the upland transects. In the stream 
transects, only one species, Duttaphrynus microtympanus, encountered in 2013 was not seen in 2014. However, I only encountered a total of 10 individuals D. microtympanus in 2013. Fourteen species were encountered during the two years (Table. 3.4). Species from three genera, Fejervarya, Micrixalus, and Indirana, were categorized as genus sp. because individuals could not be differentiated with confidence in the field. They are grouped together as a single taxon in all my analyses (Biju et al. 2014; Dinesh et al. 2015; Nair et al. 2012). Each of these genera has undergone major taxonomic revisions using molecular data (Biju et al. 2014; Dinesh et al. 2015; Nair et al. 2012). The authors of these papers have called on the community to take caution in identifying species in the field because of uncertainties associated with collection of the types, and of the locations of historical sites. These cryptic species suggest that my list of species for the Kanan Devan Tea Estates is conservative and is likely to include several more species.

Of the 14 species we encountered, six are in the first three threat categories of the IUCN red list (IUCN, 2016; Table. 3.5). Two species (Raorchestes munnarensis and Rhacophorus pseudomalabaricus) are critically endangered, two (Raorchestes dubois and Duttaphrynus microtympanum) are listed as vulnerable, and another two (Raorchestes beddommii and Duttaphrynus parietalis) are reported as near threatened (IUCN 2016). I found two species of anurans, Raorchestes kadalarensis and Duttaphrynus microtympanus, exclusive to the Rajamalla and Pettimudi site, however, only 20 individuals of Raorchestes kadalarensis and 10 individuals of Duttaphrynus microtympanus were encountered during the two-year sampling period. The critically endangered frog Rhacophorus pseudomalabaricus was found only in one shola upland 
transect at Silent Valley. The Madupetty and Thenmala site had the largest number of species, with 14 species across the four habitats (shola, tea, eucalyptus, and streams) combined. The Vaguvarrai site with the highest elevation (bordering 2000m) had the lowest species diversity (nine species). The average number of species encountered at each site, per habitat type, was highest in the shola VES transects and shola stream transects (Table. 3.6 and Table. 3.7).

In the 2013 season the most common species in the upland transects in all the months was Raorchestes dubois while the juvenile Raorchestes peaked in October (Figure 3.12). In 2014, the same pattern was seen in the upland transects (Figure 3.14). Along steam transects, Ghatixalus asterops peaked in August and November in 2013, while in 2014, the species abundance peaks are in July and October (Figure 3.13 and 3.15). The largest number of Micrixalus individuals were encountered in May and October in 2013, and August and November in 2014 (Figure 3.13 and 3.15). The juvenilies of genus Rarochestes peak in July and October in 2013, and in August and November in 2014 (Figure 3.12 and 3.15).

The meta nMDS plot shows slight overlap in community structure between the Madupetty and Thenmala site, with the Rajamallay and Pettimudi site (Figure 3.16). The lack of visual overlap in the data even with six common species is because the raw data were entered such that all site data was grouped (Figure 3.16). The Madupetty and Thenmala site, and the Rajamallay and Pettimudi site are seperated by the greatest distance. The community composition between Vaguvarrai and Silent Valley sites seem 
to be more similar to each other than with any of the other estate groups (Figure 3.16). As is expected, we see very little similarity in the species encountered in the upland transects and stream transects (Figure 3.17). Six species (Ghatixalus asterops, Raorchestes dubois, Indirana sp., Micrixalus sp., R. beddomii, and Duttaphrynus melanostictus) as well as, the Raorchestes sp. juvenile category common to all the three upland habitat types (tea, shola, and eucalyptus; Figure 3.18).

Raorchestes jayarami was found exclusively on transects located in tea in all sites except at Vaguvarrai, suggesting that it might be near its upper distribution limit of 2000m (Biju and Bossuyt 2009). In the VES surveys across the sites, R. jayarami was found exclusively on tea bushes which suggest that $R$. jayarami has developed an ability to survive in the altered agro-ecosystem. The Jayaram's Bush Frog, was the species that the local tea plantation inhabitants were most familiar with, though it is likely that they assumed both $R$. jayarami and $R$. beddomii were the same species (Biju and Bossuyt 2009). Two toads (Duttaphrynus parietalis and Duttaphrynus microtympanum) and species of the genus Fejervarya were found exclusively in the eucalyptus habitat during my studies. The terrestrial habitat of these species may allow them to survive in the altered eucalyptus habitat (Dinesh et al. 2015; IUCN 2016). Though listed as Near Threatened, the IUCN red list mentions that Duttaphrynus parietalis may be found in degraded habitats. I confirm its presence in the tea landscape in Munnar. I also encountered Duttaphrynus microtympanum, in the tea plantations, which is known to be species associated with the shola (IUCN 2016). The similariy ellipse of the sites sampled in 2014 was a subset of those from 2013 (Figure 3.11). The composition of species 
obtained using visual encounter surveys in uplands were more similar to each other than the species obtained from sampling stream transects. The tea, sholas, and eucalyptus habitats clustered together showing similar groups of species in each of the habitats across the four sites that I sampled (Figure 3.18). The ANOSIM results show that the community structure differs across sites $\left(\mathrm{R}^{2}=0.47126 \mathrm{p}<0.002\right)$, and habitats $\left(\mathrm{R}^{2}=0.15388\right.$ $\mathrm{p}<0.002)$.

\section{Discussion}

I report difference in species composition across the four sites in the tea plantations landscape in Munnar, as well as across the three habitat types (shola, eucalyptus, adn tea). According to the International Union for Conservation of Nature (IUCN), one-third of the world's amphibian species are under the threat of extinction and we lack data about the conservation status for approximately $30 \%$ of them. In the light of these declines, there is a need to study amphibian community structure in biodiversity hotspots with high amphibian endemism. The Western Ghats have been subjected to great disturbances because of humans (Krishnamurthy 2003). Deforestation, pesticides, and invasive species are some of the major threat to diverisity (Krishnamurthy 2003). Data on anuran community structure in plantations, as well as, other landscapes are required to develop and implement successful conservation strategies in such landscapes in the future (Sutherland et al. 2012).

I report the presence of a total of 14 species of anurans from four tea estate groups from the southern Western Ghats of India. Of the 14 species, seven were common to all four 
sites. Of these seven common species, three were found in shola stream transects. Ghatixalus asterops, Micrixlaus sp., and Nyctybatrachus poocha were predominantly found in stream transects in all the sites because of their strong dependence on water for breeding (Biju, et al. 2008; Biju et al. 2014). Across the KDHP landscape, Ghatixalus asterops and Micrixlaus sp. were the most abundant species found in stream transects. Individuals of Ghatixalus asterops were encountered repeatedly along the same stream transects and sometimes on exactly the same perch (even though all individuals were released in the middle of transects) suggesting that these species may maintain site fidelity. Future studies are required to understand the social behavior of G. asterops.

The community structure did not vary between 2013 and 2014, which is somewhat interesting given that 2013 was reported to be a drought year (Figure 3.7). All four sites received higher average rainfall in June than July in year 2013, while in 2014, the average rainfall across all the sites was the highest in July (Figure 3.6) and there was high variance around the monthly precipitation at each site in the landscape. The early heavy rainfall in June 2013 (monsoon) did not affects the patterns observed in 2014 (Figure 3.6).

The list of species from the region now provides a baseline for anuran community structure in this area and ideally will play a part in long term studies looking at trends of the anuran communities at the four sites in the landscape over time. In my pilot study in 2012, I encountered 17 species of anurans (all juveniles Raorchestes sp. were lumped) using standard amphibian surveying methods (species not encountered in 2013-2014: 
Uperodon cf montanus, Raorchestes chlorosomma, R. anili, and Ghatixalus magnus) and another seven species (species absent in 2013-2014: Rhacophorus calacadensis, Raorchestes sushili, R. theuerkaufi, R. uthamani, Micrixalus sp., Beddomixalus bijui, and Nyctibatrachus acanthodermis) were encountered opportunistically in 2012 in the Kannaimallai and Periavarrai Estates. These species were not encountered using standard methods in the four sites that were sampled during 2013-2014, neither were they encountered opportunisitically in the four sites. We believe that Kannaimalli and Perriavarai Estates that were sampled during 2012 support a high species diversity compared to the other sites sampled in 2013 and 2014. This is probably because Kannaimalli and Perivarai estates are close to the Eravikulam National Park and fall in the elevational belt $1400-2000 \mathrm{~m}$ asl.

According to Vijaykumar et al. (2016), there is an increased species richness of Raorchests species between $1400 \mathrm{~m}$ and $1800 \mathrm{~m}$ near the Anamallai hills. Of the ten species not encountered in the four sites during 2013 and 2014, five species belong to genus Raorchestes. Another species Beddomixalus bijui was described from its type location, which is only 13 miles away from Kanniamallai estate. Compared to data reported in Daniels (2001), the Western Ghats now support 198 species of amphibians and $80 \%$ of them are endemic, as most of the newly descried are endemic to the mountain range (Frost 2016). Though the 14 species I sampled, is not extremely diverse as might be expected (see CHAPTER 2), the seven rhacophorid species found in the estates are endemic to Munnar (Vijaykumar et al. 2016; IUCN 2016). The species of Raorchestes are known to be direct developers, and I observed several instances of amplexus and egg 
laying away from water (Biju and Bossuyt 2009; Biju et al. 2010). The bush frogs, Rarchestes jayarami, R. kadalarensis, and R. munnarensis were never encountered in stream transects, however, some recently metamorphosed individuals were encountered along streams. It is likely that these offspring were either of $R$. dubois or $R$. beddomii, whose adults were encountered along the vegetation in the stream transects. The five species from the genus Raorchestes encountered in the present study: Raorchestes munnarensis, $R$. kadalarensis, $R$. dubois, $R$. beddommii, and $R$. jayarami, are unique to the Anamalai Hills, and are only reported above 1400m asl (Vijaykumar et al. 2016).

The type specimen of $R$. munnarensis was collected adjacent to tea bushes on the route to Munnar, and in the present study I report that the species was found at all the sites except for Vaguvarrai (Biju and Bossuyt 2009). Rarchestes jayarami, R. kadalarensis, and $R$. munnarensis were not encountered at Vaguvarrai which includes areas with elevations between $1900 \mathrm{~m}$ and $2000 \mathrm{~m}$ asl. Raorchestes kadalarensis, was described in 2011 on the basis on two specimens collected near the Kadalar Estate, which shares boundaries with the Rajamallai and Pettimudi sites of the present study (Zachariah et al. 2011). I encountered 20 individuals of $R$. kadalarensis, across habitats, sites, and years. All of the individuals were found along an upland shola transect in the Rajamallai and Pettimudi site. The species was opportunistically observed in the Kannaimallai Estate which also shares boundaries with the Kadalar Estate. Since it is yet to be assessed by the IUCN, we recommend that its distribution in four abutting tea Estates (Kadalar, Kannaimallai, Rajamallai, and Pettimudi) be taken into consideration (IUCN 2016). In the present study, I encountered individuals of $R$. beddommii in all the upland habitats, and in all the 
four sites; however, only six individuals were encountered in the Vaguvarrai site, suggesting it was near the upper limit of its distributional range. The species is closely related to the critically endangered species $R$. resplendens that is reported only inside the Eravikulam National Park (Biju et al. 2010). In its description, R. jayarami was reported to be collected from a shola forest in Valparai region of the Anamallai hills (Biju and Bossuyt 2009; Vijaykumar et al. 2016) I report its presence on tea bushes in plantations in the Munnar region of the Anamallai hills. Raorchestes jayarami, was abundant on tea bushes at all sites except at Vaguvarrai. The frogs in the type series of $R$. dubois were collected from shrubs (1m high) and one of the paratypes was collected from the Eravikulam National Park. In the present study, $R$. dubois was the most abundant species across all the habitats, including Vaguvarrai (Biju and Bossuyt 2009). The juvenilies of genus Rarochestes peak in July and October in 2013, and in August and November in 2014 suggesting a bimodal pattern in the egg laying of the adults, matching the two monsoon seasons (southwest in June and northeast in October). Ghatixalus asterops, a tree frog described in 2008 is still reported as data deficient by the IUCN redlist (Biju et al. 2008; IUCN, 2016). The present study shows that it is a locally abundant species, found perched on low vegetation along the sides of, as well as, perched on overhanging vegetation in streams across the four sites I surveyed. Even though the critically endangered frog Rhacophorus pseudomalabaricus was found only in one shola upland transect of Silent Valley, different life history stages of the species have been opportunistically observed in the Kadalar and Kannaimallai Estates in Munnar (Harpalani et al. 2015; IUCN 2016). Specimens of Nyctybatrachus poocha were collected from the Munnar area from small hill streams and the present study found the species to be 
abundant only in stream transects, across all the four sites (Biju et al. 2011). The individuals were found in the streams or on rocks and grass along the banks of the streams. The species is difficult to handle. On several occasions we noticed egg clutches laid in rocky crevices, just above the water line.

There are studies on novel difference breeding behavior associated with other species in the Nyctybatrachus genus, including mud packing to prevent desiccation of egg masses and the dorsal straddle, and dorsal release of sperm onto the female (Gururaja et al. 2014; Willaert et al. 2016). Though egg clutches were observed, we did not observe breeding in the species. The species of the Torrent Frog genus Micrixalus were observed abundantly only in stream transects across the four sites, with the highest abundance in the Silent Valley. Across the landscape, we found individuals of this species along the banks of the streams or in the streams which is the usual habitat of the species (Biju et al. 2014). We also encountered individuals from Micrixalus from the Kannaimallai Estate, in the 2012 field season. The behavior of foot flagging is reported from individuals of Micrixalus saxicola and the behavior was observed in individuals of the genus Micrixalus, on occasion during my study (Preininger et al. 2013). There was no information on the morphology of the tadpoles from the genus Micrixalus, until Senevirathne et al. (2016) described the tadpoles of Micrixalus herrei. The tadpoles of the genus are fossorial until the late stages before metamorphosis (Senevirathne et al. 2016). On one occasion, I encountered a tadpole from the genus Micrixalus, in a stream from the Madupetty Estate. Individuals from the genera Fejervarya and Indirana, were encountered in low numbers along the upland shola transects and streams transects in the current study. During both 
the field seasons, a local marsh which received runoff from tea fields, in the Kannaimallai Estate appeared to have several calling individuals, as well as, aquatic tadpoles of species from the genus Fejervarya. Individuals from both Fejervarya and Indirana were encountered in the Rajamallai and Pettimudi site, while we only found individuals of Indirana sp. at the Vaguvarrai site and the Madupetty-Thenmala site. I only found Fejervarya sp. at the Silent Valley site. Veeranagoudar et al. (2009) report the semiaquatic nature of tadpoles of the Indirana genus. We opportunistically observed tadpoles on moist rock faces in the Vaguvarrai site, during the present study. Additional work is required on trying to carefully identify species using morphological traits, especially from the recently revised genera, Fejervarya, Micrixalus, and Indirana (Biju et al. 2014; Dinesh et al. 2015; Nair et al. 2012). Species specific studies on the reproductive biology of the amphibians in this landscape need to be conducted.

In his study 10-day study in Valparai, Daniels (2003) reported 13 species of amphibians from a single tea estate and this number compares with the number of species encountered in at each site in my study (Md_Th: 10 species; Ra_Pt: 14 species; SV: 11 species; Vg: 8 species) and juvenile Raorchestes sp. which were found at all sites. It is important to remember that the list I complied is conservative because of the presence of several cryptic species. Wordley et al. (2015), found eight out of ten species of bats in a tea plantation dominated landscape in state of Tamil Nadu in southern India. In the light of such studies reporting the presence of species in tea plantations and the anuran species richness and community structure reported in this study from an actively managed tea plantation, both in the same biodiversity hotspot, we are reminded of the role agro- 
ecosystems can play in supporting the native biodiversity of an area. Grant et al. (2016) reported a diverse number of drivers for declining amphibians in North America and recommended that conservation plans needed to be tailored to each locality in question, even though amphibian declines are reported on a global scale. With all the information existing on declines of amphibians all over the globe, it is now time to conduct and learn from species specific targeted interventions (Sutherland et al. 2012). With the exponentially increasing human population, the pressures on existing agricultural and plantation lands are only going to keep increasing (Nielsen 2016). Trying to increase awareness among the stake holders managing these land holding can possibly lead to more sustainable long term measures which allow certain subsets of native species to take refuge in microhabitats provided by these systems.

\section{Acknowledgements}

I thank Florida International University for a graduate assistantship which allowed for data collection. I thank the Wildlife Institute of India, Dehradun, India and Dr.

Karthikeyan Vasudevan for the Research Associate post provided from 2012 to 2015 and

I thank the KDHP Private Ltd. for permission to work on the tea plantation property in Munnar, Kerala. I also thank Elangovan (Tribal Field assistant) for help with field work.

\section{Literature Cited}

Alford, R. A., and S. J. Richards. 1999. Global amphibian declines: A problem in applied ecology. Annual Review of Ecology and Systematics. 30:133-165. 
Bali, A., Kumar, A. and Krishnaswamy, J., 2007. The mammalian communities in coffee plantations around a protected area in the Western Ghats, India. Biological Conservation. 139:93-102.

Berger, L., Speare, R., and A. D. Hyatt. 1999. Chytrid fungi and amphibian declines: Overview, implications and future directions. Tropical Medicine. Canberra. 2333.

Bickford, D., Howard, S. D., Ng D. J. J., and J. A. Sheridan. 2010. Impacts of climate change on the amphibians and reptiles of Southeast Asia. Biodiversity Conservation. 19:1043-1062.

Biju, S. D. and F. Bossuyt. 2005. New Species of Philautus (Anura: Ranidae, Rhacophorinae) from Ponmudi hills in the Western Ghats of India. Journal of Herpetology. 39:349-353.

Biju, S.D. and F. Bossuyt. 2009. Systematics and phylogeny of Philautus Gistel, 1848 (Anura, Rhacophoridae) in the Western Ghats of India, with descriptions of 12 new species. Zoological Journal of the Linnean Society. 155:74-444.

Biju, S.D., Roelants, K. and Bossuyt, F., 2008. Phylogenetic position of the montane treefrog Polypedates variabilis Jerdon, 1853 (Anura: Rhacophoridae), and description of a related species. Organisms Diversity and Evolution. 8:267-276.

Biju, S.D., Shouche, Y., Dubois, A., Dutta, S.K. and Bossuyt, F., 2010. The Western Ghats of India. Current Science. 98:1119-1125.

Biju, S.D., Van Bocxlaer, I., Mahony, S., Dinesh, K.P., Radhakrishnan, Zachariah, A., Giri, V., Bossuyt, F., 2011. A taxonomic review of the night frog genus Nyctibatrachus Boulenger, 1882 in the Western Ghats, India (Anura: Nyctibatrachidae) with description of twelve new species. Zootaxa. 3029:1-96.

Biju, S.D., Garg, S., Gururaja, K.V., Shouche, Y. and Walujkar, S.A., 2014. DNA barcoding reveals unprecedented diversity in dancing frogs of India (Micrixalidae, Micrixalus): A taxonomic revision with description of 14 new species. Ceylon Journal of Science (Biological Science): 43: 37-123.

Blaustein, R. A., and M. J. Kiesecker. 2002. Complexity in conservation: Lessons from the global decline of amphibian populations. Ecology Letters. 5:597-608.

Bossuyt, F. 2002. A new species of Philautus (Anura: Ranidae) from the Western Ghats of India. Journal of Herpetology. 36:656-661.

Bossuyt, F., Meegaskumbura, M., Beenaerts, N., Gower, D.J., Pethiyagoda, R., Roelants, K., Mannaert, A., Wilkinson, M., Bahir, M.M., Manamendra-Arachchi, K. and 
Ng, P.K., 2004. Local endemism within the Western Ghats-Sri Lanka biodiversity hotspot. Science. 306:479-481.

Bremer, L.L. and Farley, K.A., 2010. Does plantation forestry restore biodiversity or create green deserts? A synthesis of the effects of land-use transitions on plant species richness. Biodiversity and Conservation. 19:3893-3915.

Bunyan, M., Bardhan, S. and Jose, S., 2012. The shola (tropical montane forest)grassland ecosystem mosaic of peninsular India: A review. American Journal of Plant Sciences. 3:1632-1639.

Cassano, C.R., Schroth, G., Faria, D., Delabie, J.H. and Bede, L., 2009. Landscape and farm scale management to enhance biodiversity conservation in the cocoa producing region of southern Bahia, Brazil. Biodiversity and Conservation. 18: 577-603.

Champion, S.H. and Seth, S.K., 1968. A revised survey of the forest types of India. Government of India Publication. New Delhi.

Chen, S.B., Wei, Z.J., Zeng, Z.H., Chen, L.L., Chen, H.T. and You, M.S., 2009. Effects of nitrogen application on beetle communities in tea plantations. Insect Science. 16:185-192.

Conservation International. 2012. http://www.biodiversityhotspots.org.

Crump, M. L., and Scott Jr, N.J., 1994. Visual encounter surveys. In W. R. Heyer, M. A. Donnelly, R. W. McDiarmid, L. C. Hayek, and M. S. Foster (eds.), Measuring and Monitoring Biological Di- versity: Standard Methods for Amphibians, pp. 84-92. Smithsonian Institution Press, Washington, DC.

Cushman, S.A., 2006. Effects of habitat loss and fragmentation on amphibians: A review and prospectus. Biological Conservation. 128:231-240.

Daniels, R. J. R. 1991. The problem of conserving amphibians in the Western Ghats, India. Current Science. 60:630-632.

Daniels, R. J. R. 1992. Geographical distribution patterns of amphibians in the Western Ghats, India. Journal of Biogeography. 19:521-529.

Daniels R. J. R. 2001. National Biodiversity Strategy and Action Plan: Western Ghats Eco-region. Report submitted to Ministry of Environment and Forests, Government of India.

Daniels, R. J. R. 2003. Impact of tea cultivation on anurans in the Western Ghats. Current Science. 85:1415-1422. 
Dinesh, K.P., Vijayakumar, S.P., Channakeshavamurthy, B.H., Toreskar, V.R., Kulkarni, N.U. and Shanker, K., 2015. Systematic status of Fejervarya (Amphibia, Anura, Dicroglossidae) from South and SE Asia with the description of a new species from the Western Ghats of Peninsular India. Zootaxa. 3999:79-94.

Doan, T. M. 2003. Which methods are most effective for surveying rain forest herpetofauna? Journal of Herpetology. 37:72-81.

Donnelly, M. A., Chen, M. H., and G. G. Watkins. 2005. Sampling amphibians and reptiles in the Iwokrama Forest Ecosystem. Proceedings of the academy of Natural Sciences of Philadelphia. 154:55-69.

European Union MRL, 2015. http://ec.europa.eu/food/plant/pesticides/max_residue_levels/eu_rules/mrls_2015_ en.htm

Ewers, R.M. and Didham, R.K., 2006. Confounding factors in the detection of species responses to habitat fragmentation. Biological Reviews. 81:117-142.

FAO, 2011. Global Forest Resources Assessment. 2010. www.fao.org, Rome, Italy.

Fahrig, L., 2003. Effects of habitat fragmentation on biodiversity. Annual Review of Ecology, Evolution, and Systematics. 34:487-515.

Ficetola, G.F., 2015. Habitat conservation research for amphibians: Methodological improvements and thematic shifts. Biodiversity and Conservation. 24:1293-1310.

Fischer, J. and Lindenmayer, D.B., 2007. Landscape modification and habitat fragmentation: A synthesis. Global Ecology and Biogeography. 16:265-280.

Frost, D. R. 2016. Amphibian Species of the World: An Online Reference. Version 6.0 Electronic Database accessible at http://research.amnh.org/herpetology/amphibia/index.html. American Museum of Natural History, New York, USA.

Gardner, T.A., Barlow, J. and Peres, C.A., 2007a. Paradox, presumption and pitfalls in conservation biology: The importance of habitat change for amphibians and reptiles. Biological Conservation. 138:166-179.

Gardner, T.A., Riberio-Junior, M.A., Barlow, J.O.S., Ávil-Pires, T.C.S., Hoogmoed, M.S. and Peres, C.A., 2007b. The value of primary, secondary, and plantation forests for a neotropical herpetofauna. Conservation biology. 21:775-787. 
Grant, E.H.C., Miller, D.A., Schmidt, B.R., Adams, M.J., Amburgey, S.M., Chambert, T., Cruickshank, S.S., Fisher, R.N., Green, D.M., Hossack, B.R. and Johnson, P.T., 2016. Quantitative evidence for the effects of multiple drivers on continental-scale amphibian declines. Scientific Reports. DOI:10.1038/srep25625.

Gunawardene, N.R., Daniels, D.A., Gunatilleke, I.A.U.N., Gunatilleke, C.V.S., Karunakaran, P.V., Nayak, G.K., Prasad, S., Puyravaud, P., Ramesh, B.R., Subramanian, K.A. and Vasanthy, G., 2007. A brief overview of the Western Ghats-Sri Lanka biodiversity hotspot. Current Science. 93:1567-1572.

Gururaja, K.V., Dinesh, K.P., Priti, H. and Ravikanth, G., 2014. Mud-packing frog: A novel breeding behaviour and parental care in a stream dwelling new species of Nyctibatrachus (Amphibia, Anura, Nyctibatrachidae). Zootaxa. 3796:033-061.

Harpalani, M., Parvathy, S., Kanagavel, A., Eluvathingal, L. and Tapley, B., 2015. Note on range extension, local knowledge and conservation status of the critically endangered Anamalai Gliding Frog Rhacophorus pseudomalabaricus in the Cardamom Hills of Western Ghats, India. Herpetological Bulletin. 133:1-6.

Harding, G., Griffiths, R.A. and Pavajeau, L., 2015. Developments in amphibian captive breeding and reintroduction programs. Conservation Biology. 30:340-349.

Hegde, V.D., 2012. Amphibian fauna of arecanut plantation in Kadatoka (Uttara Kannada) Western Ghats, Karnataka. Frog leg. 18:10-20.

Hoffmann, M., Hilton-Taylor, C., Angulo, A., Böhm, M., Brooks, T.M., Butchart, S.H., Carpenter, K.E., Chanson, J., Collen, B., Cox, N.A. and Darwall, W.R., 2010. The impact of conservation on the status of the world's vertebrates. Science. 330: 1503-1509.

IUCN 2016. The IUCN Red List of Threatened Species. Version 2016-2. $<$ http://www.iucnredlist.org>. Downloaded on 04 September 2016.

Kanan Devan Hill Plantation Cooperation Private Limited Management Plan. 2012. Munnar Press. Kerala, India.

Kolby, J. E., and Daszak, P. 2016. The emerging amphibian fungal disease, chytridiomycosis: A key example of the global phenomenon of wildlife emerging infectious diseases. Microbiology Spectrum. 4: DOI:10.1128/microbiolspec.EI100004-2015.

Krishnamurthy, S. V. 2003. Amphibian assemblages in undisturbed and disturbed areas of Kudremukh National Park, central Western Ghats, India. Environmental Conservation. 30:274-282. 
Lo Seen, D., Ramesh, B.R., Nair, K.M., Martin, M., Arrouays, D. and Bourgeon, G., 2010. Soil carbon stocks, deforestation and land-cover changes in the Western Ghats biodiversity hotspot (India). Global Change Biology. 16:1777-1792.

Martel, A., Spitzen-van der Sluijs, A., Blooi, M., Bert, W., Ducatelle, R., Fisher, M.C., Woeltjes, A., Bosman, W., Chiers, K., Bossuyt, F. and Pasmans, F., 2013. Batrachochytrium salamandrivorans sp. nov. causes lethal chytridiomycosis in amphibians. Proceedings of the National Academy of Sciences. 110:1532515329.

Myers, N., Mittermeier, R.A., Mittermeier, C.G., Da Fonseca, G.A. and Kent, J., 2000. Biodiversity hotspots for conservation priorities. Nature. 403:853-858.

Nair, A., Gopalan, S.V., George, S., Kumar, K.S., Teacher, A.G.F. and Merilä, J., 2012. High cryptic diversity of endemic Indirana frogs in the Western Ghats biodiversity hotspot. Animal Conservation. 15:489-498.

Nielsen, R.W., 2016. Growth of the world population in the past 12,000 years and its link to the economic growth. Journal of Economics Bibliography. 3:1-12.

Nowakowski, J. A., Watling, J. I., Whitfield, S. M., Todd, B. D., Kurz, D. J., and M. A. Donnelly. 2016. Tropical amphibians in shifting thermal landscapes under land use and climate change. Conservation Biology. DOI:10.1111/cobi.12769.

Oksanen, J., Blanchet, F.G., Kindt, R., Legendre, P., Minchin, P.R., O’Hara, R.B., Simpson, G.L., Solymos, P., Stevens, M.H.H. and Wagner, H., 2015. vegan: community ecology package. 2015. R package version 3.3.0.

Pechmann, J. H. K., Scott, D. E., Semlitsch, R. E., Caldwell, J. P., Vitt, L. J., and J. W. Gibbons. 1991. Declining amphibian populations: the problem of separating human impacts from natural fluctuations. Science. 253:892-899.

Preininger, D., Boeckle, M., Freudmann, A., Starnberger, I., Sztatecsny, M. and Hödl, W., 2013. Multimodal signaling in the small torrent frog (Micrixalus saxicola) in a complex acoustic environment. Behavioral Ecology and Sociobiology. 67:14491456.

Rodgers, W. A. and Panwar, H. S. 1988. Planning a Protected Area Network in India. Volume I: The Report. Wildlife Institute of India. Dehradun

Rollins-Smith, L.A. 2016. Amphibian immunity, stress, disease, and climate change, Developmental and Comparative Immunology.

DOI:org/10.1016/j.dci.2016.07.002 
Saunders, D.A., Hobbs, R.J. and Margules, C.R., 1991. Biological consequences of ecosystem fragmentation: A review. Conservation biology. 5:18-32.

Senevirathne, G., Garg, S., Kerney, R., Meegaskumbura, M. and Biju, S.D., 2016. Unearthing the Fossorial Tadpoles of the Indian Dancing Frog Family Micrixalidae. PloS One. 11: DOI: org/10.1371/journal.pone.0151781.

Shalleck, J. 1972. Tea. New York: Viking Press.

Sutherland, W.J., Mitchell, R. and Prior, S.V., 2012. The role of 'Conservation Evidence' in improving conservation management. Conservation Evidence. 9(20120000):12.

Tea Board of India, 2016. http://www.teaboard.gov.in

Thomas, S. and Palmer, M., 2007. The montane grasslands of the Western Ghats, India: community ecology and conservation. Community Ecology. 8:67-73.

Van Bocxlaer, I., Biju, S.D., Loader, S.P. and Bossuyt, F., 2009. Toad radiation reveals into-India dispersal as a source of endemism in the Western Ghats-Sri Lanka biodiversity hotspot. BioMed Central Evolutionary Biology. DOI: 10.1186/14712148-9-131.

Veeranagoudar, D.K., Radder, R.S., Shanbhag, B.A. and Saidapur, S.K., 2009. Jumping behavior of semiterrestrial tadpoles of Indirana beddomii (Günth.): Relative importance of tail and body size. Journal of Herpetology. 43:680-684.

Vijayakumar, S.P., Menezes, R.C., Jayarajan, A. and Shanker, K., 2016, August. Glaciations, gradients, and geography: Multiple drivers of diversification of bush frogs in the Western Ghats Escarpment. Proceeding of the Royal Society (Biology). 283: DOI:10.1098/rspb.2016.1011.

Vitousek, P.M., Mooney, H.A., Lubchenco, J. and Melillo, J.M., 1997. Human domination of Earth's ecosystems. Science. 277:494-499.

von May, R. 2009. Amphibian community structure as a function of forest types in Southeastern Peru. Chapter 4. Doctoral dissertation. Submitted to Graduate School, Florida International University.

von May, R. and Donnelly, M.A., 2009. Do trails affect relative abundance estimates of rainforest frogs and lizards? Austral Ecology. 34: 613-620.

Wanger, T.C., Iskandar, D.T., Motzke, I., Brook, B.W., Sodhi, N.S., Clough, Y. and Tscharntke, T., 2010. Effects of Land-Use Change on Community Composition of 
Tropical Amphibians and Reptiles in Sulawesi, Indonesia. Conservation Biology. 24:795-802.

Watling, I. J. and Donnelly, A. D. 2006. Fragments as Islands: A synthesis of faunal responses to habitat patchiness. Conservation Biology. 20:1016-1025.

Watling, J.I., Nowakowski, A.J., Donnelly, M.A. and Orrock, J.L., 2011. Meta-analysis reveals the importance of matrix composition for animals in fragmented habitat. Global Ecology and Biogeography. 20:209-217.

Whitfield, S.M., Lips, K.R. and Donnelly, M.A., 2016. Amphibian decline and conservation in central america. Copeia. 104:351-379.

Willaert, B., Suyesh, R., Garg, S., Giri, V.B., Bee, M.A. and Biju, S.D., 2016. A unique mating strategy without physical contact during fertilization in Bombay night frogs (Nyctibatrachus humayuni) with the description of a new form of amplexus and female call. PeerJ. doi.org/10.7717/peerj.2117.

Wordley, C.F., Sankaran, M., Mudappa, D. and Altringham, J.D., 2015. Landscape scale habitat suitability modelling of bats in the Western Ghats of India: Bats like something in their tea. Biological Conservation. 191:529-536.

Wright, S.J., 2005. Tropical forests in a changing environment. Trends in Ecology and Evolution. 20:553-560.

Zachariah, A., K. P. Dinesh, E. Kunhikrishnan, S. Das, D. V. Raju, C. Radhakrishnan, M. J. Palot, and S. Kalesh. 2011. Nine new species of frogs of the genus Raorchestes (Amphibia: Anura: Rhacophoridae) from southern Western Ghats, India. Biosystematica. 5:25-48. 


\section{Tables}

\begin{tabular}{|c|c|c|c|}
\hline Group & Total Species & Endemic Species & \% Endemism \\
\hline Angiosperms & 4000 & 1500 & 38 \\
\hline Butterflies & 330 & 37 & 11 \\
\hline Fishes & 218 & 116 & 53 \\
\hline Amphibians & 121 & 94 & 78 \\
\hline Reptiles & 156 & 97 & 62 \\
\hline Birds & 508 & 19 & 4 \\
\hline Mammals & 120 & 14 & 12 \\
\hline
\end{tabular}

Table. 3.1. Endemism in the Western Ghats (Daniels 2001). 


\begin{tabular}{|c|c|c|}
\hline Group & Name and dosage & $\begin{array}{c}\text { Maximum Residue } \\
\text { Level (MRL mg Kg }\end{array}$ \\
\hline Organochlorine compounds
\end{tabular}

Table 3.2. Pesticides commonly used on tea and the maximum residues levels of pesticides permitted by the European Union Regulation (European Union MRL, 2015). 


\begin{tabular}{|c|c|c|c|}
\hline Sno & Species Name & Current Name & Breeding Comments \\
\hline $\mathbf{1}$ & Bufo melanostictus & Duttaphrynus melanostictus & Explosive breeding \\
\hline $\mathbf{2}$ & Philautus variabilis & Raorchestes variabilis & Calling observed \\
\hline $\mathbf{3}$ & Rhacophorus pseudomalabaricus & Rhacophorus pseudomalabaricus & None observed \\
\hline $\mathbf{4}$ & Euphylctis cyanophlyctis & Euphylctis cyanophlyctis & Calling observed \\
\hline $\mathbf{5}$ & Indirana beddomii & Indirana beddomii & None observed \\
\hline $\mathbf{6}$ & Nyctibatrachus beddomii & Nyctibatrachus beddomii & Calling observed \\
\hline $\mathbf{7}$ & Nyctibatrachus species & Nyctibatrachus species & None observed \\
\hline $\mathbf{8}$ & Rana temporalis & Indosylvirana temporalis & Calling observed \\
\hline $\mathbf{9}$ & Rana aurantiaca & Indosylvirana aurantiaca & Breeding and all stages observed \\
\hline $\mathbf{1 0}$ & Limnonectes bervipalmata & Fejervarya bervipalmata & Adults and juveniles seen \\
\hline $\mathbf{1 1}$ & Limnonectes keralensis & Fejervarya keralensis & Juveniles and metamorphs seen \\
\hline $\mathbf{1 2}$ & Limnonectes limnocharis & Fejervarya limnocharis & Confused with F . limnocharis \\
\hline $\mathbf{1 3}$ & Limnonectes nilagirica & Fejervarya nilagirica & \\
\hline
\end{tabular}

Table. 3.3. All species observed by Daniels in a tea plantation along with updated names (Daniels 2003; Frost 2016). 


\begin{tabular}{|c|c|c|c|c|}
\hline & English name & Species name & IUCN & Endemism \\
\hline \multicolumn{5}{|c|}{ I. ORDER ANURA } \\
\hline \multicolumn{5}{|c|}{ 1. Family BUFONIDAE (toads) } \\
\hline 1 & Common Indian Toad & Duttaphrynus melanostictus & LC & \\
\hline 2 & Small-eared Toad & Duttaphrynus microtymphanum & VU & WG \\
\hline 3 & Ridged Toad & Duttaphrynus parietalis & NT & WG \\
\hline \multicolumn{5}{|c|}{ 2. Family DICROGLOSSIDAE (fork tongued frogs) } \\
\hline 4 & Fejervarya & Fejervarya $\mathrm{sp}$ & & \\
\hline \multicolumn{5}{|c|}{ 3. Family MICRIXALIDAE (dancing frogs) } \\
\hline 5 & Micrixalus & Micrixalus sp & $\mathrm{NE}$ & KL \\
\hline \multicolumn{5}{|c|}{ 4. Family NYCTIBATRACHIDAE (night frogs) } \\
\hline 6 & Nyctibatrachus & Nyctibatrachus poocha & $\mathrm{NE}$ & KL \\
\hline \multicolumn{5}{|c|}{ 5. Family RANIXALIDAE (leaping frogs) } \\
\hline 7 & Indirana & Indirana $\mathrm{sp}$ & & \\
\hline \multicolumn{5}{|c|}{ 6. Family RHACOPHORODAE (tree frogs) } \\
\hline 8 & Ghat Tree Frog & Ghatixalus asterops & $\mathrm{DD}$ & WG \\
\hline 9 & Beddome's Bush Frog & Raorchestes beddommii & NT & WG \\
\hline 10 & Kodaikanal Bush Frog & Raorchestes dubois & VU & WG \\
\hline 11 & Jayaram's Bush Frog & Raorchestes jayarami & $\mathrm{NE}$ & WG \\
\hline 12 & Kadalar Bush Frog & Raorchestes kadalarensis & $\mathrm{NE}$ & KL \\
\hline 13 & Munnar Bush Frog & Raorchestes munnarensis & $\mathrm{CR}$ & WG \\
\hline 14 & $\begin{array}{c}\text { Malabar False Tree } \\
\text { Frog }\end{array}$ & Rhacophorus pseudomalabaricus & $\mathrm{CR}$ & WG \\
\hline
\end{tabular}

Table. 3.4. All species (minus juvenile Raorchestes $\mathrm{sp}$ ) encountered in this study from all four estate groups (LC: Least Concern; VU: Vulnerable; NE: Not Evaluated; DD: Data Deficient; NT: Near Threatened; CR: Critically Endangered; KL: Kerala; WG: Western Ghats). 


\begin{tabular}{|c|c|c|c|c|c|c|c|}
\hline Serial No & English name & Species name & IUCN & Endemism & Eucalyptus & Shola & Tea \\
\hline \multicolumn{8}{|c|}{ I. ORDER ANURA } \\
\hline \multicolumn{8}{|c|}{ 1. Family BUFONIDAE (toads) } \\
\hline 1 & Common Indian Toad & Duttaphrynus melanostictus & Least Concern & India & Present & Present & Present \\
\hline 2 & Small-eared Toad & Duttaphrynus microtymphanum & Vulnerable & India & Present & Absent & Absent \\
\hline 3 & Ridged Toad & Duttaphrynus parietalis & Not Threatened & India & Present & Absent & Absent \\
\hline \multicolumn{8}{|c|}{ 2. Family DICROGLOSSIDAE (fork tongued frogs) } \\
\hline 4 & Fejervarya & Fejervarya $\mathrm{sp}$ & - & Western Ghats & Present & Absent & Absent \\
\hline \multicolumn{8}{|c|}{ 3. Family MICRIXALIDAE (dancing frogs) } \\
\hline 5 & Micrixalus & Micrixalus sp & - & Kerala & Present & Present & Present \\
\hline \multicolumn{8}{|c|}{ 4. Family NYCTIBATRACHIDAE (night frogs) } \\
\hline 6 & Nyctibatrachus & Nyctibatrachus poocha & Not Evaluated & Kerala & Absent & Absent & Present \\
\hline \multicolumn{8}{|c|}{ 5. Family RANIXALIDAE (leaping frogs) } \\
\hline 7 & Indirana & Indirana $\mathrm{sp}$ & - & Western Ghats & Present & Present & Present \\
\hline \multicolumn{8}{|c|}{ 6. Family RHACOPHORODAE (tree frogs) } \\
\hline 8 & Ghat Tree Frog & Ghatixalus asterops & Data Defficient & Kerala & Present & Present & Present \\
\hline 9 & Beddome's Bush Frog & Raorchestes beddommii & Near Threatened & Kerala & Present & Present & Present \\
\hline 10 & Kodaikanal Bush Frog & Raorchestes dubois & Vulnerable & Western Ghats & Present & Present & Present \\
\hline 11 & Kadalar Bush Frog & Raorchestes kadalarensis & Not Evaluated & Kerala & Absent & Present & Absent \\
\hline 12 & Jayaram's Bush Frog & Raorchestes jayarami & Not Evaluated & Kerala & Absent & Absent & Present \\
\hline 13 & Munnar Bush Frog & Raorchestes munnarensis & Critically Endangered & Kerala & Absent & Present & Present \\
\hline \multirow[t]{2}{*}{14} & Malabar False Tree Frog & Rhacophorus pseudomalabaricus & Critically Endangered & Western Ghats & Absent & Present & Absent \\
\hline & Totals & & & & $9(3)$ & $9(2)$ & $9(2)$ \\
\hline
\end{tabular}

Table. 3.5. All species encountered in this study using Visual Encounter Surveys (VES) from all four estate groups with information on presence and absence in each habitat and number of excusive species in each habitat in parenthesis. 


\begin{tabular}{|c|c|c|c|c|c|c|c|}
\hline \multirow{2}{*}{ Sites } & & \multicolumn{2}{|c|}{ Total of species per habitat } & \multicolumn{2}{|c|}{ Average no of individuals per habitat } & \multirow{2}{*}{ Species/person-hour } & \multirow{2}{*}{ Avg Individuals/person-hour } \\
\hline & & 2013 & 2014 & 2013 & 2014 & & \\
\hline \multirow{3}{*}{ Md_Tm } & Shola & 6 & 6 & $3.15 \pm 0.42$ & $1.85 \pm 0.22$ & 0.22 & $0.51 \pm 0.08$ \\
\hline & Tea & 7 & 7 & $1.48 \pm 0.15$ & $0.85 \pm 0.08$ & 0.26 & $0.23 \pm 0.03$ \\
\hline & Eucalyptus & 6 & 7 & $1.30 \pm 0.27$ & $1.19 \pm 0.21$ & 0.24 & $0.22 \pm 0.05$ \\
\hline \multirow{3}{*}{ Ra_Pt } & Shola & 8 & 8 & $2.78 \pm 0.22$ & $2.78 \pm 0.25$ & 0.30 & $0.43 \pm 0.11$ \\
\hline & Tea & 4 & 4 & $1.11 \pm 0.19$ & $1.48 \pm 0.23$ & 0.15 & $0.19 \pm 0.06$ \\
\hline & Eucalyptus & 6 & 5 & $2.19 \pm 0.28$ & $1.11 \pm 0.17$ & 0.20 & $0.35 \pm 0.05$ \\
\hline \multirow{3}{*}{ SV } & Shola & 6 & 6 & $4.07 \pm 0.56$ & $3.30 \pm 0.40$ & 0.22 & $0.66 \pm 0.14$ \\
\hline & Tea & 4 & 6 & $1.33 \pm 0.17$ & $1.67 \pm 0.18$ & 0.19 & $0.21 \pm 0.07$ \\
\hline & Eucalyptus & 3 & 3 & $0.89 \pm 0.14$ & $0.93 \pm 0.14$ & 0.11 & $0.15 \pm 0.04$ \\
\hline \multirow{3}{*}{$\mathrm{Vg}$} & Shola & 5 & 5 & $2.96 \pm 0.50$ & $2.07 \pm 0.35$ & 0.19 & $0.49 \pm 0.09$ \\
\hline & Tea & 2 & 6 & $0.48 \pm 0.09$ & $3.70 \pm 0.54$ & 0.15 & $0.08 \pm 0.16$ \\
\hline & Eucalyptus & 4 & 4 & $3.22 \pm 0.69$ & $2.48 \pm 0.50$ & 0.15 & $0.56 \pm 0.11$ \\
\hline
\end{tabular}

Table. 3.6. Summary of average number of species and average number of individual encountered at each site and habitat type using Visual Encounter Surveys (Calculated for each site ( 3 replicates $* 15$ minutes $*$ repeated 18 times $* 2$ observers) $/ 60=27$ hours per habitat). 


\begin{tabular}{|c|c|c|c|c|c|c|}
\hline \multirow{2}{*}{ Sites } & \multicolumn{2}{|c|}{ Total No of species } & \multicolumn{2}{c|}{ Average No of Individuals in streams } & \multirow{2}{*}{ Species/person-hour } & \multirow{2}{*}{ Individuals/person-hour } \\
\cline { 2 - 5 } & 2013 & 2014 & 2013 & 2014 & 0.20 & $0.13 \pm 0.02$ \\
\hline Md_Tm & 4 & 7 & $2.48 \pm 0.36$ & $4.52 \pm 0.48$ & 0.26 & $0.23 \pm 0.04$ \\
\hline Ra_Pt & 8 & 6 & $5.93 \pm 0.88$ & $6.33 \pm 1.11$ & 0.26 & $0.28 \pm 0.04$ \\
\hline SV & 7 & 7 & $7.37 \pm 1.01$ & $7.78 \pm 1.03$ & 0.26 & $0.14 \pm 0.02$ \\
\hline Vg & 5 & 5 & $4.07 \pm 0.73$ & $3.59 \pm 0.62$ & 0.19 & \\
\hline
\end{tabular}

Table. 3.7. Summary of average number of species and average individual counts from each estate group for shola stream transects (Calculated for each estate ( 3 replicates*30 minutes*repeated 18 times $* 2$ observers $) / 60=54$ hours per habitat). 


\section{Figures}

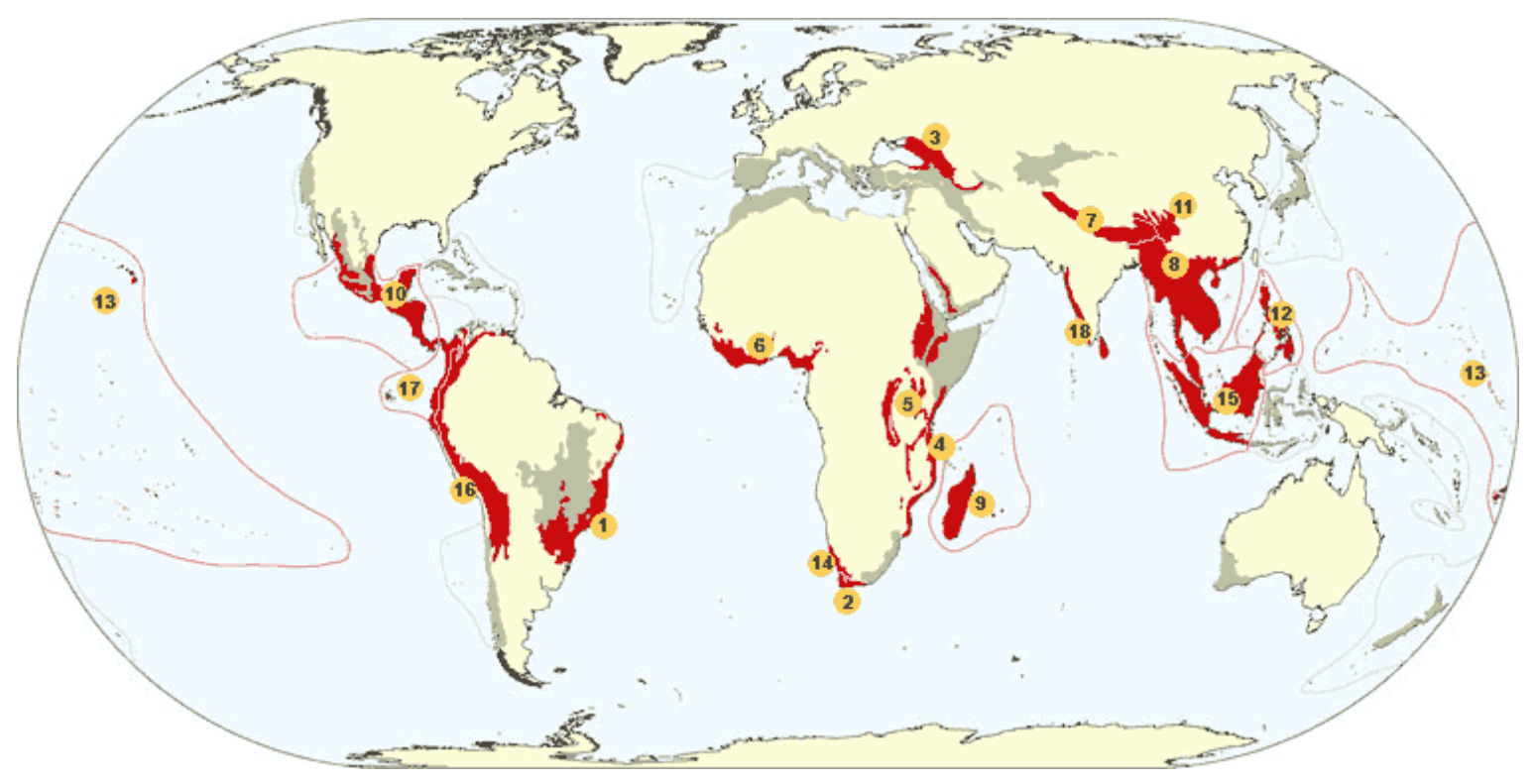

Figure 3.1. The 25 biodiversity hotspots of the world (Conservational International, 2012). 


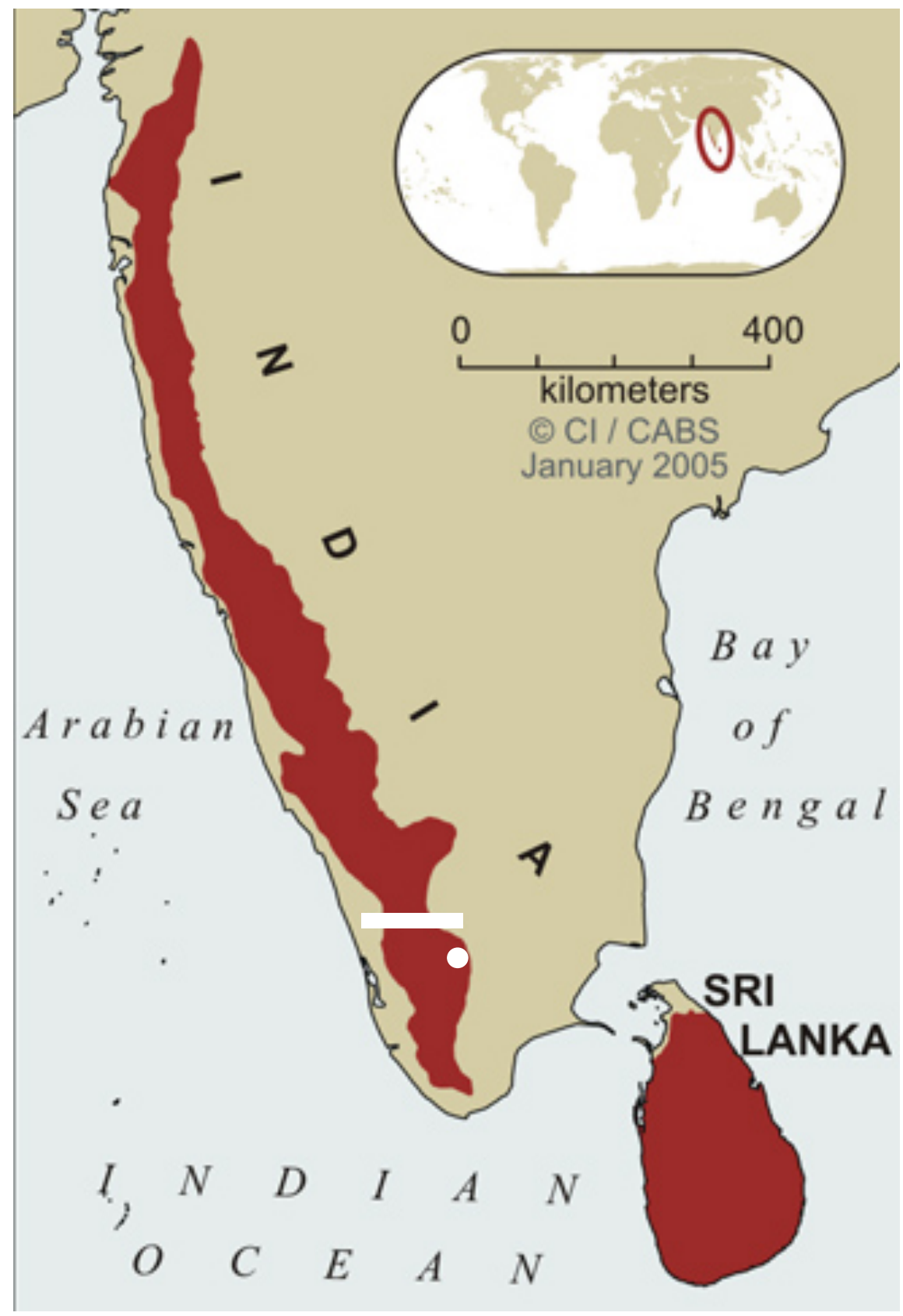

Figure 3.2. The Western Ghats and Sri Lanka Biodiversity Hotspot with a white dot marking the study area which is South of the the Palghat gap (white dash; Map from IUCN, 2016). 


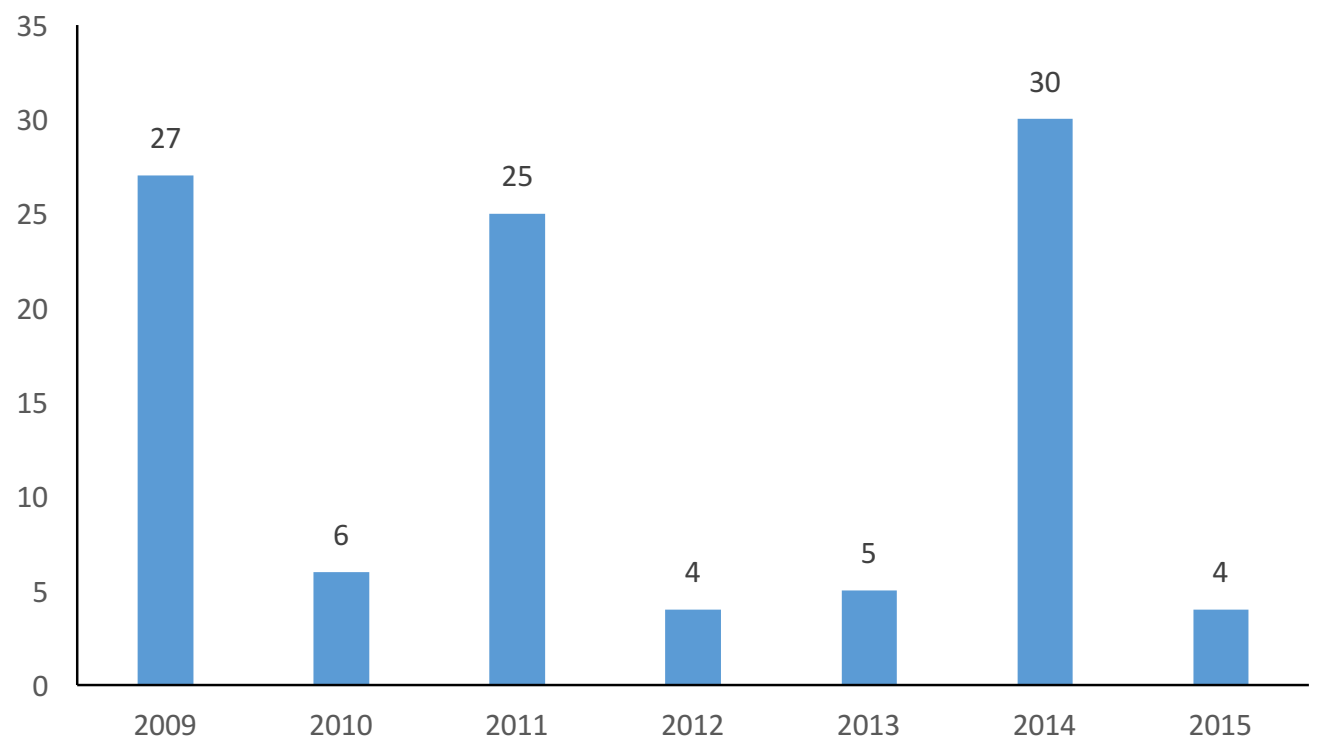

Figure 3.3. Number of amphibian species described in India from 2009 to 2015 (Frost, 2016). 


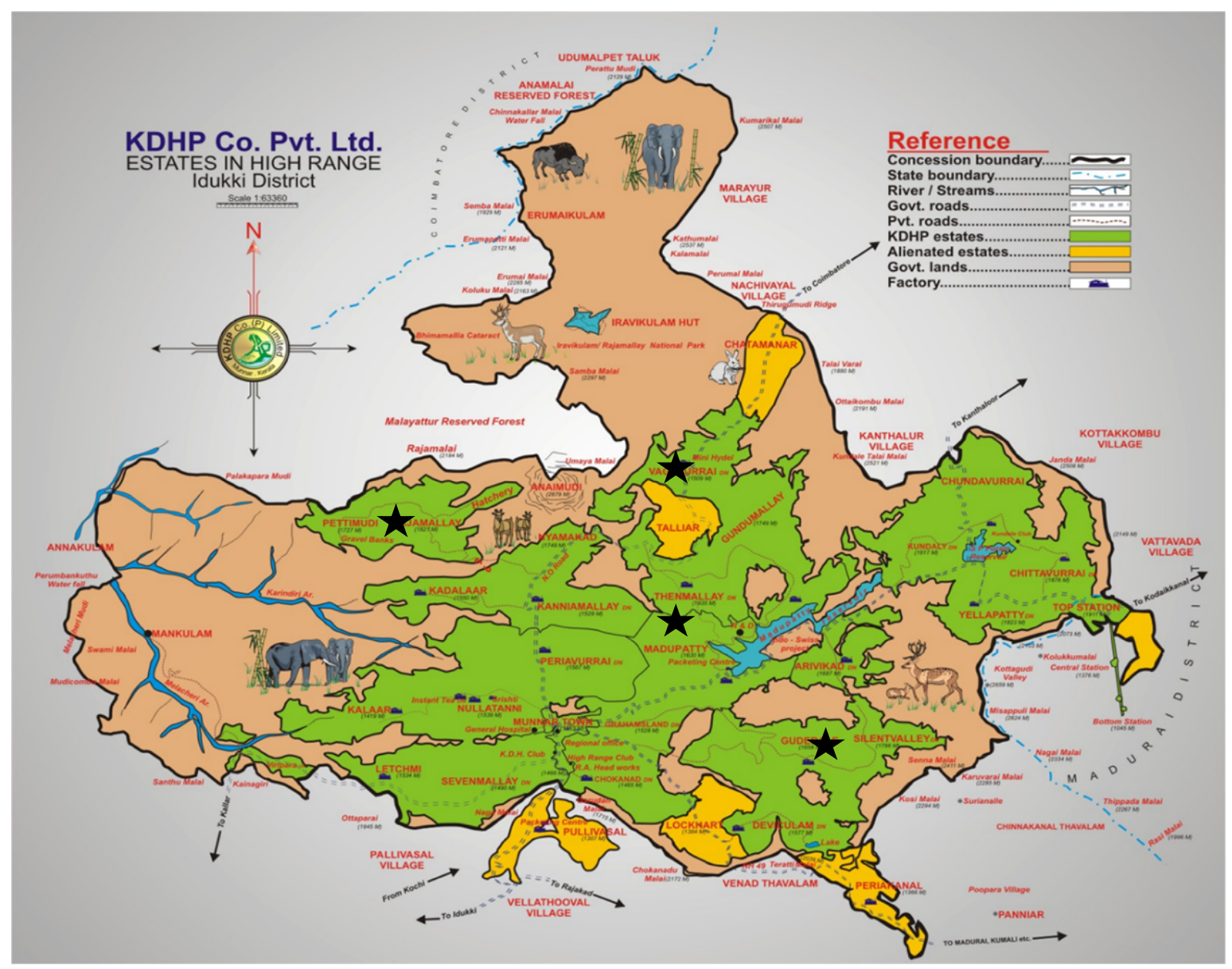

Figure 3.4 .Map of KDHP Co Lt. with the estates where sampling was conducted (Kanan Devan Hills Private Cooperation Limited). 


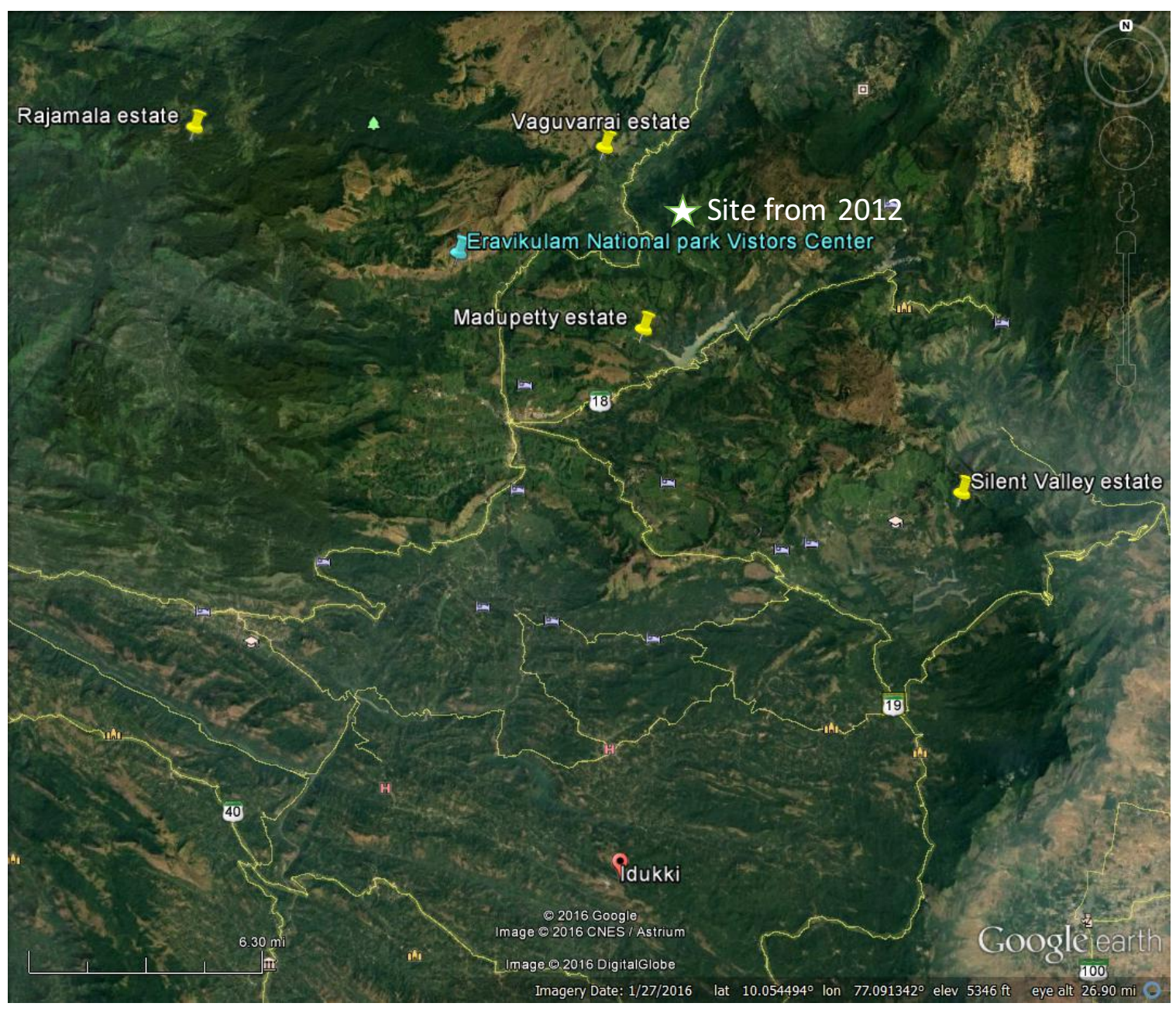

Figure 3.5. KDHP map with the four estate groups (1. Vaguvarrai; 2. Rajamallay and Pettimudi; 3. Madupetty and Thenmala; 4. Silent Valley) marked (Google maps, 2016). 


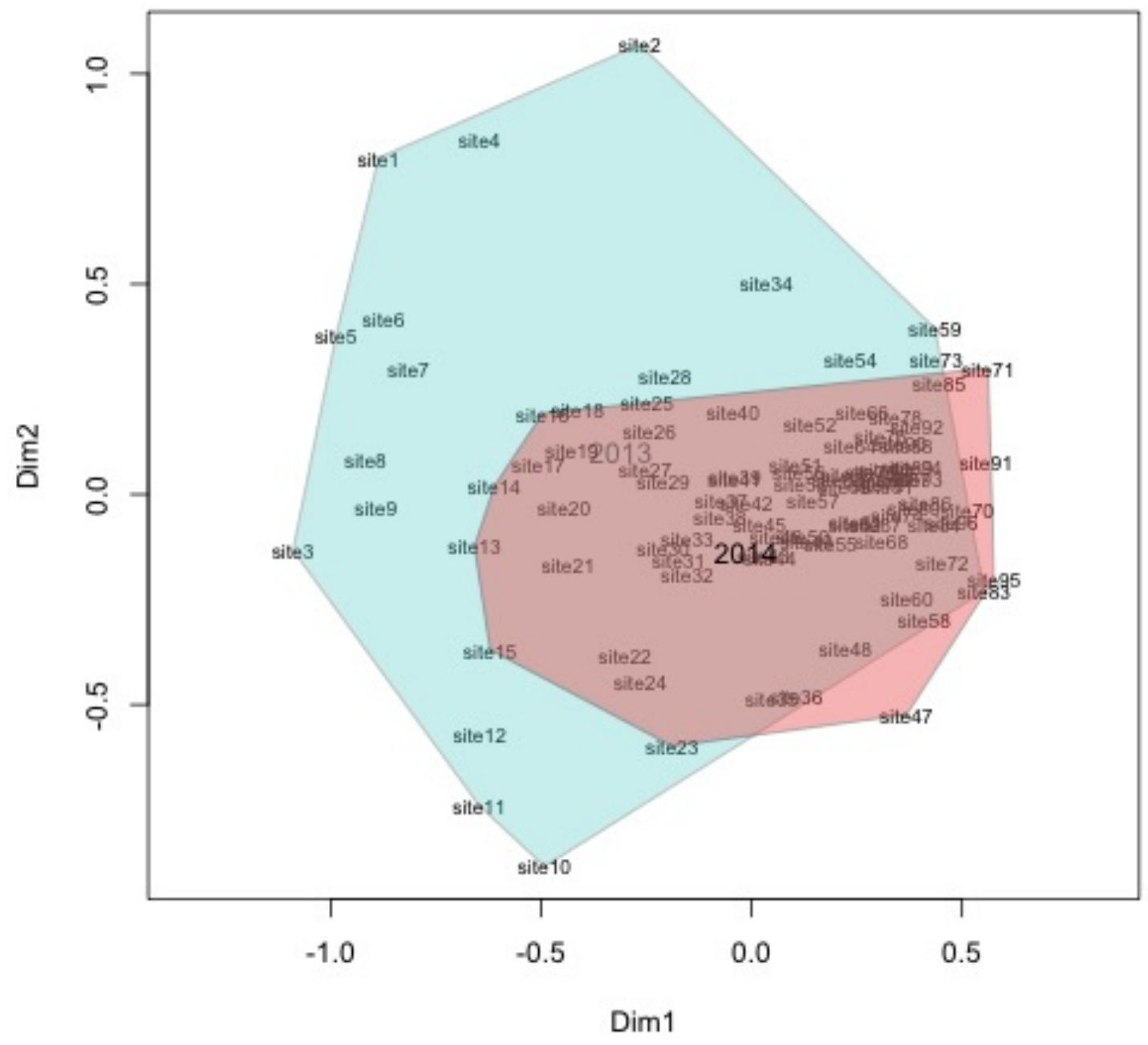

Figure 3.6. MetanMDS plot of similarity with ellipses drawn around samples from each year, 2013 and 2014 (Stress: 0.2510247). 

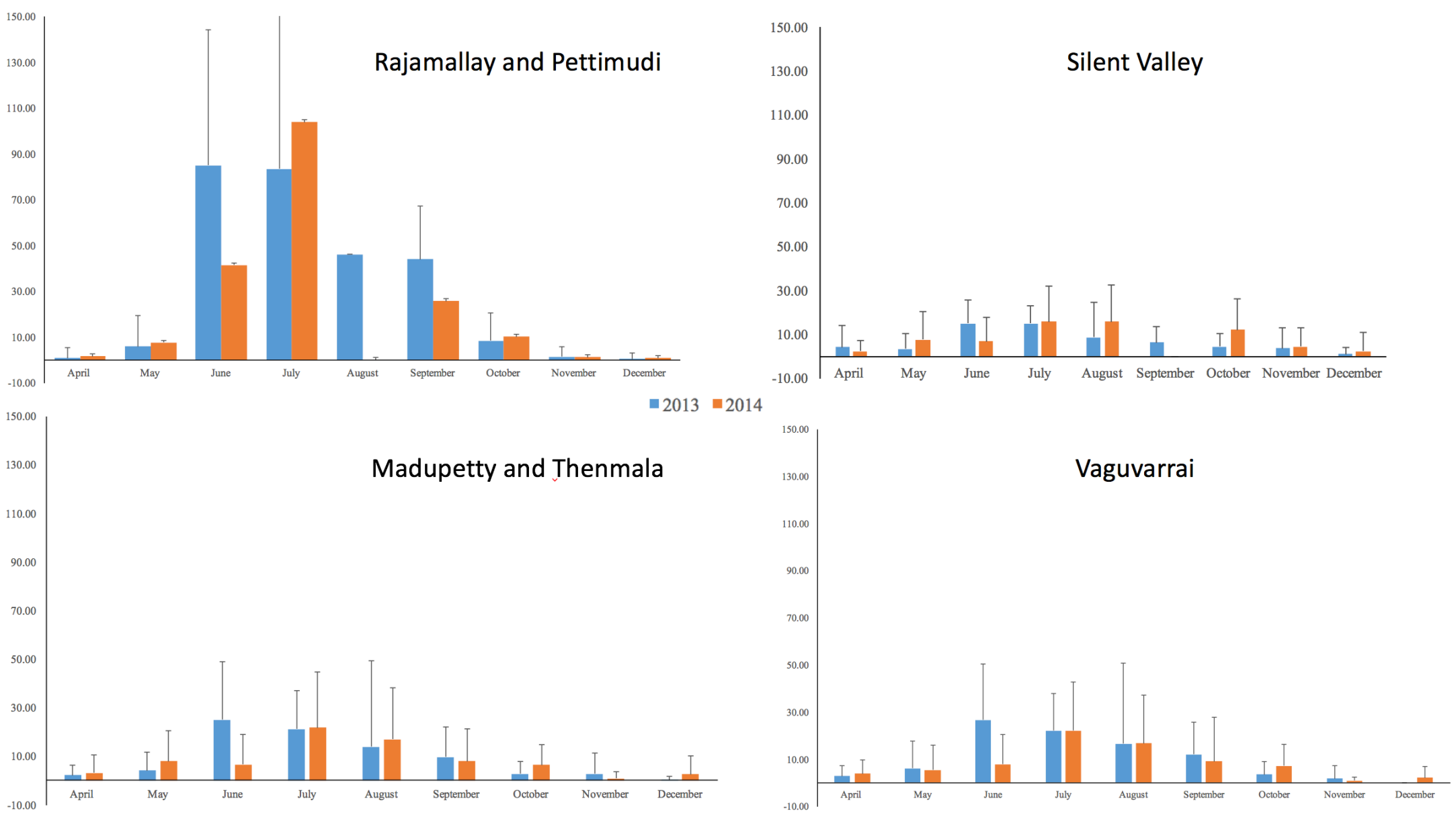

Figure 3.7. Average monthly Rainfall in mm(+1Standard Deviation) for years 2013 and 2014 in Rajamallay and Pettimudi, Silent Vally, Madupetty and Thenmala, and Vaguvarrai sites, Munnar. 


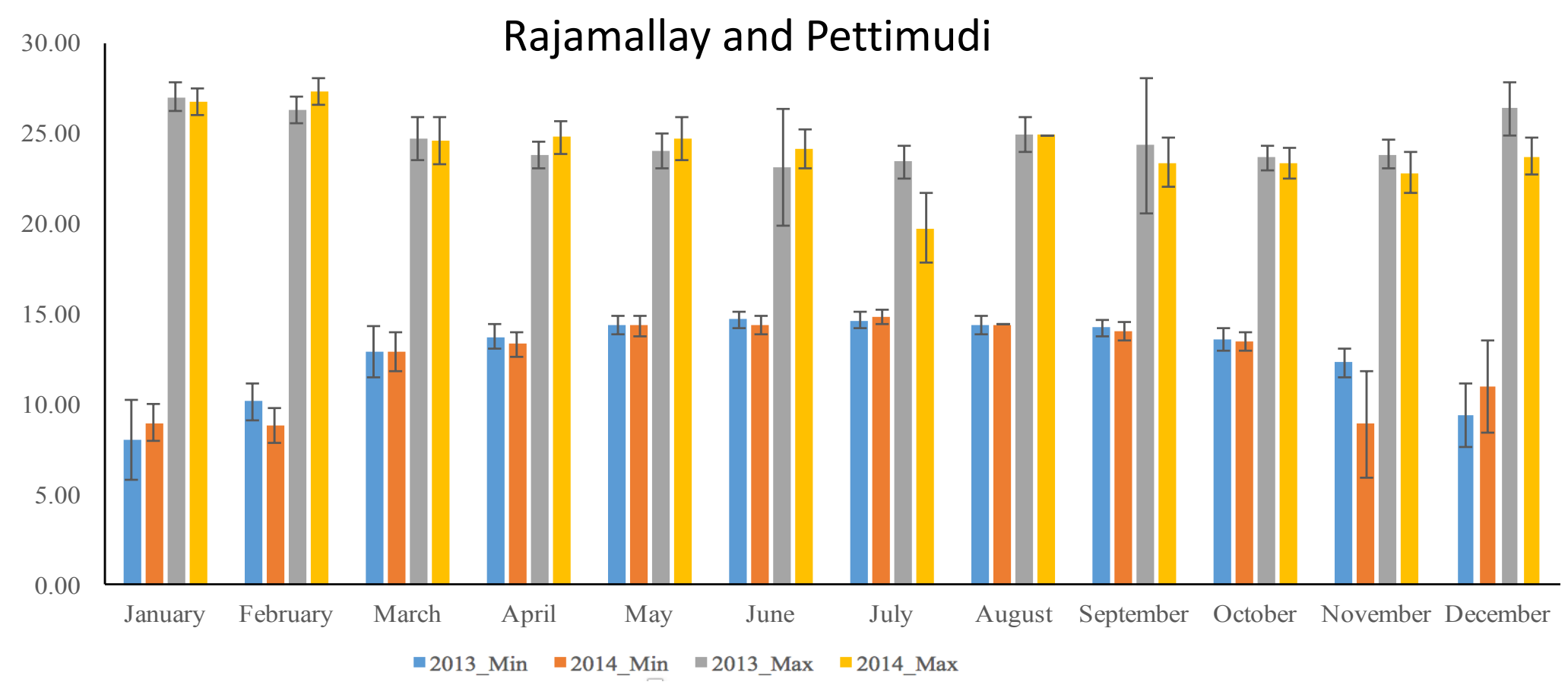

Figure 3.8. Average ( \pm Standard Deviation) monthly minimum and maximum temperature in degrees Celcius for years 2013 and 2014 in the Rajamallay and Pettimud site, Munnar. 


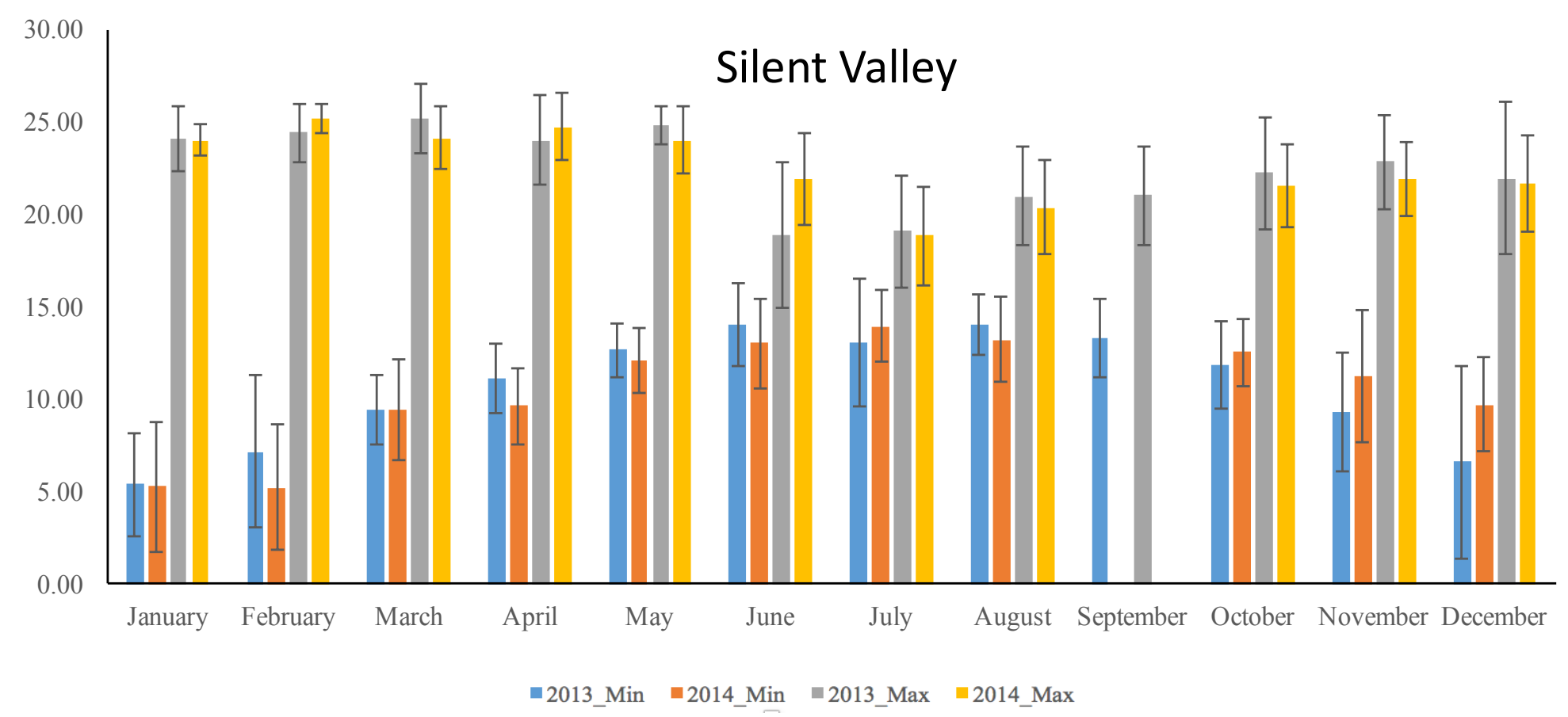

Figure 3.9. Average ( \pm Standard Deviation) monthly minimum and maximum temperature in degrees Celcius for years 2013 and 2014 in the Silent Vally site, Munnar. 


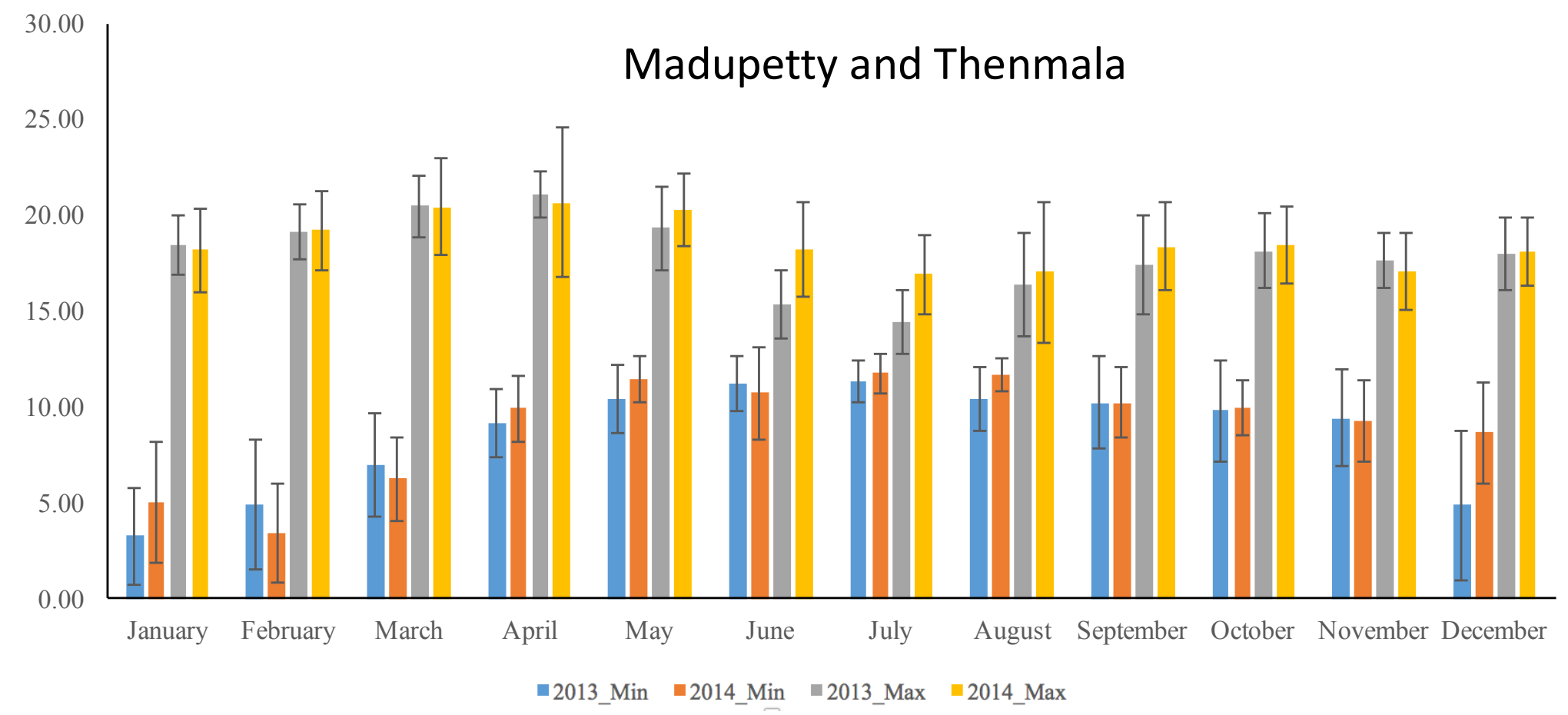

Figure 3.10. Average ( \pm Standard Deviation) monthly minimum and maximum temperature in Celcius for years 2013 and 2014 in the Madupetty and Thenmala site, Munnar. 


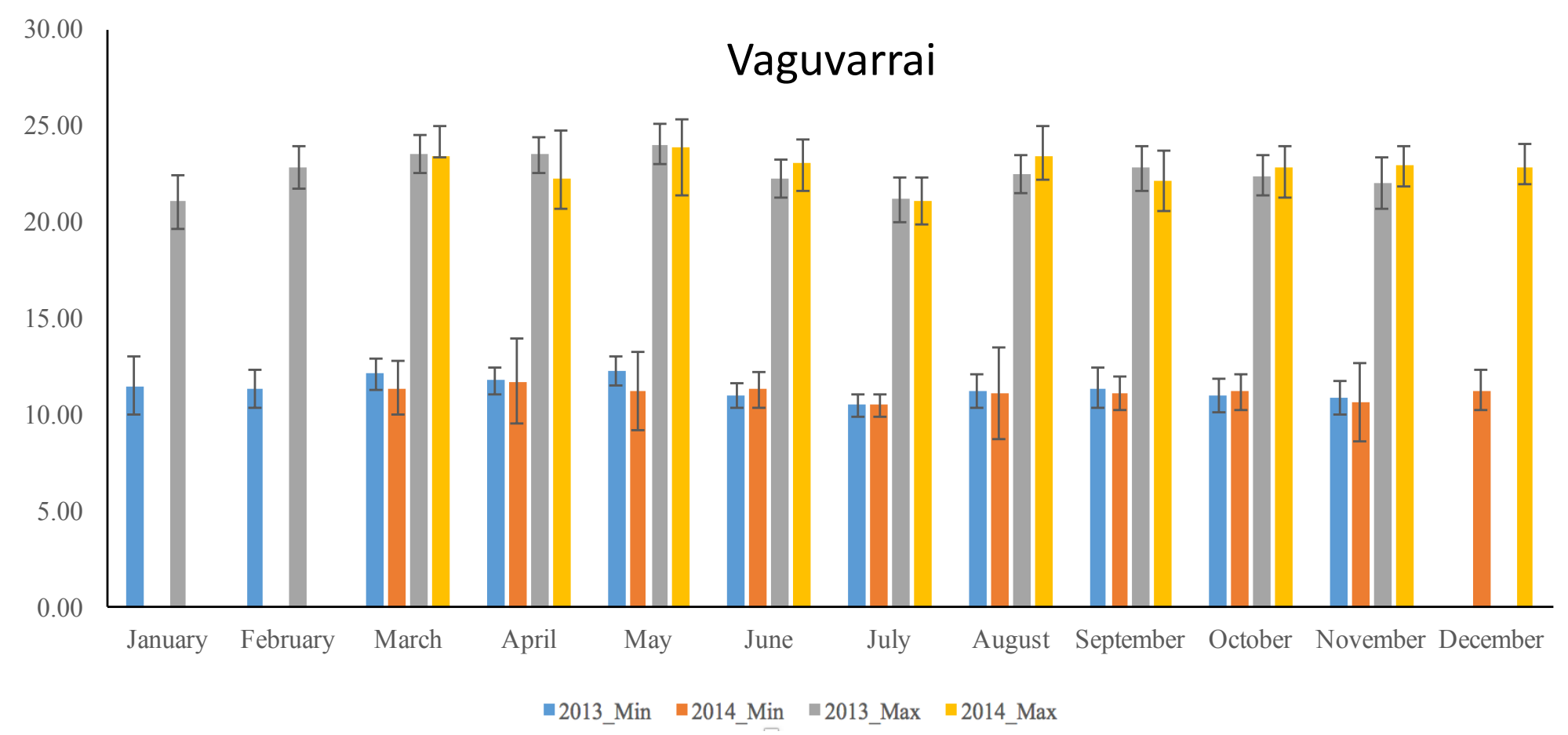

Figure 3.11 Average ( \pm Standard Deviation) monthly minimum and maximum temperature in Celcius for years 2013 and 2014 in the Vaguvarrai site, Munnar 


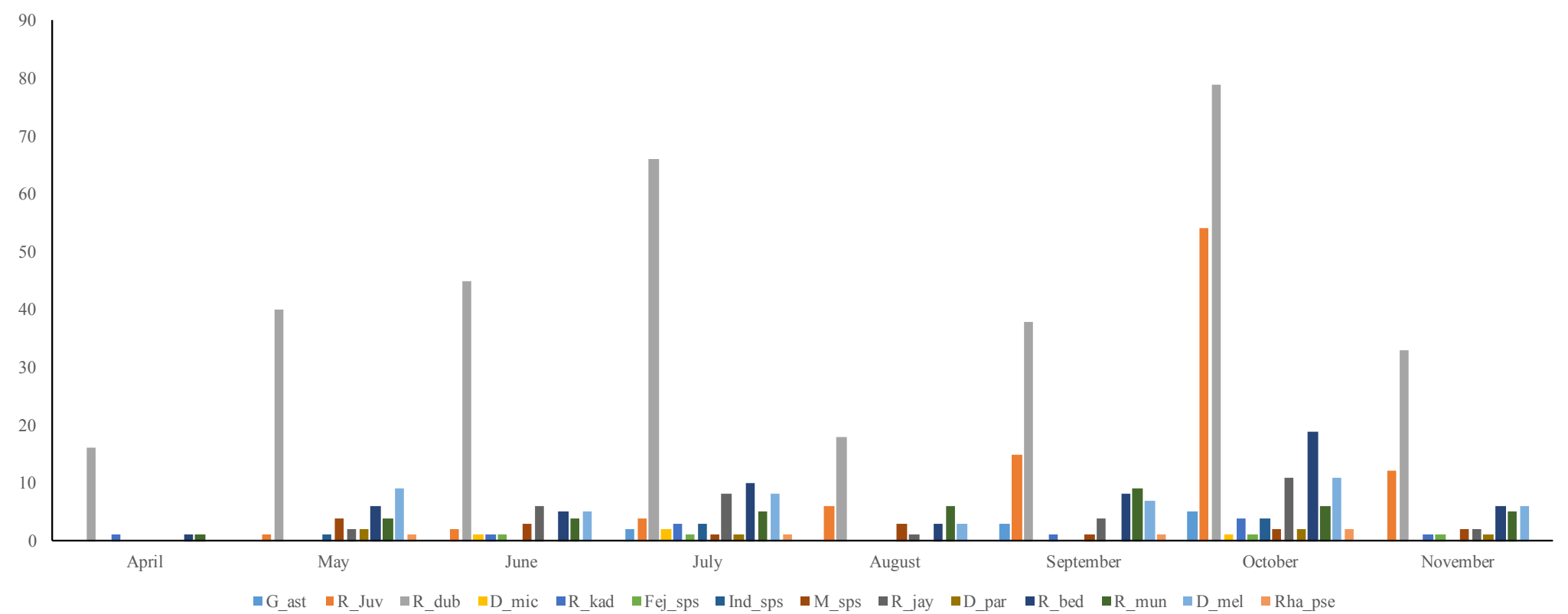

Figure 3.12. Species encountered per month in 2013 in the upland transects. 


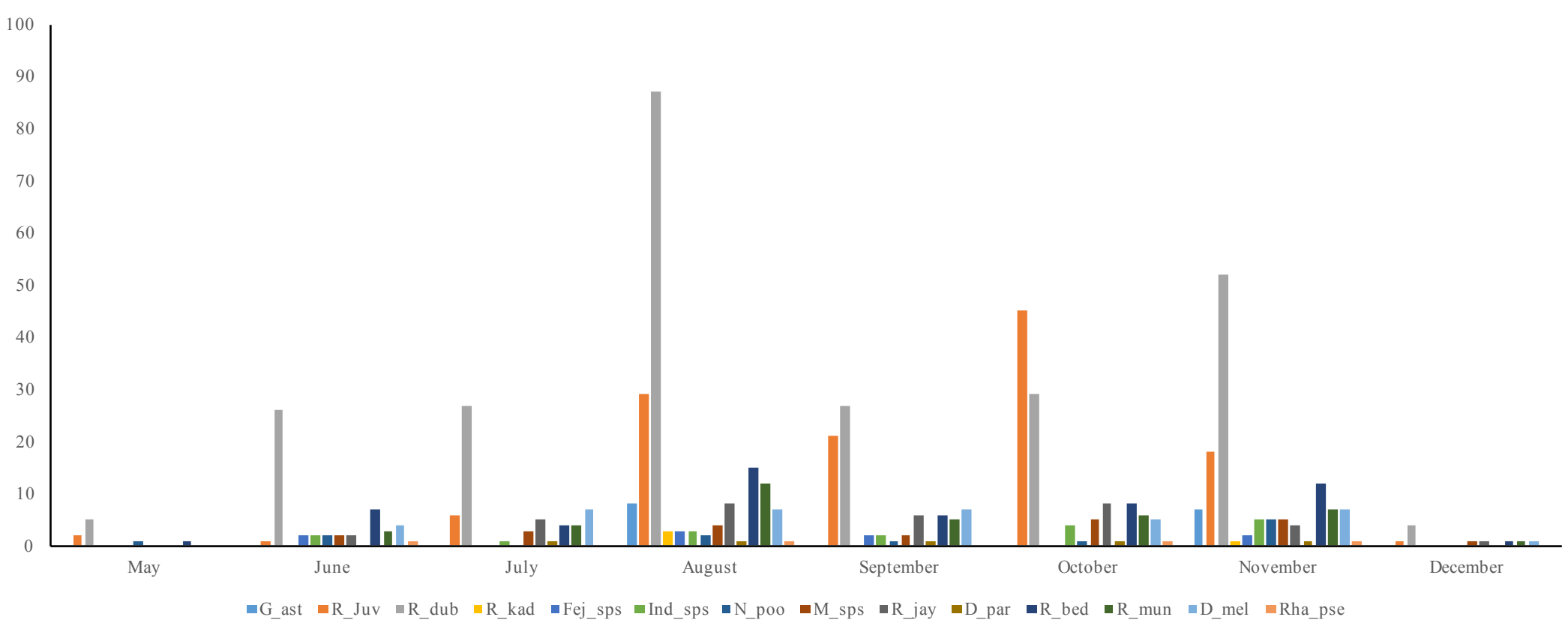

Figure 3.13. Species encountered per month in 2014 in the upland transects. 


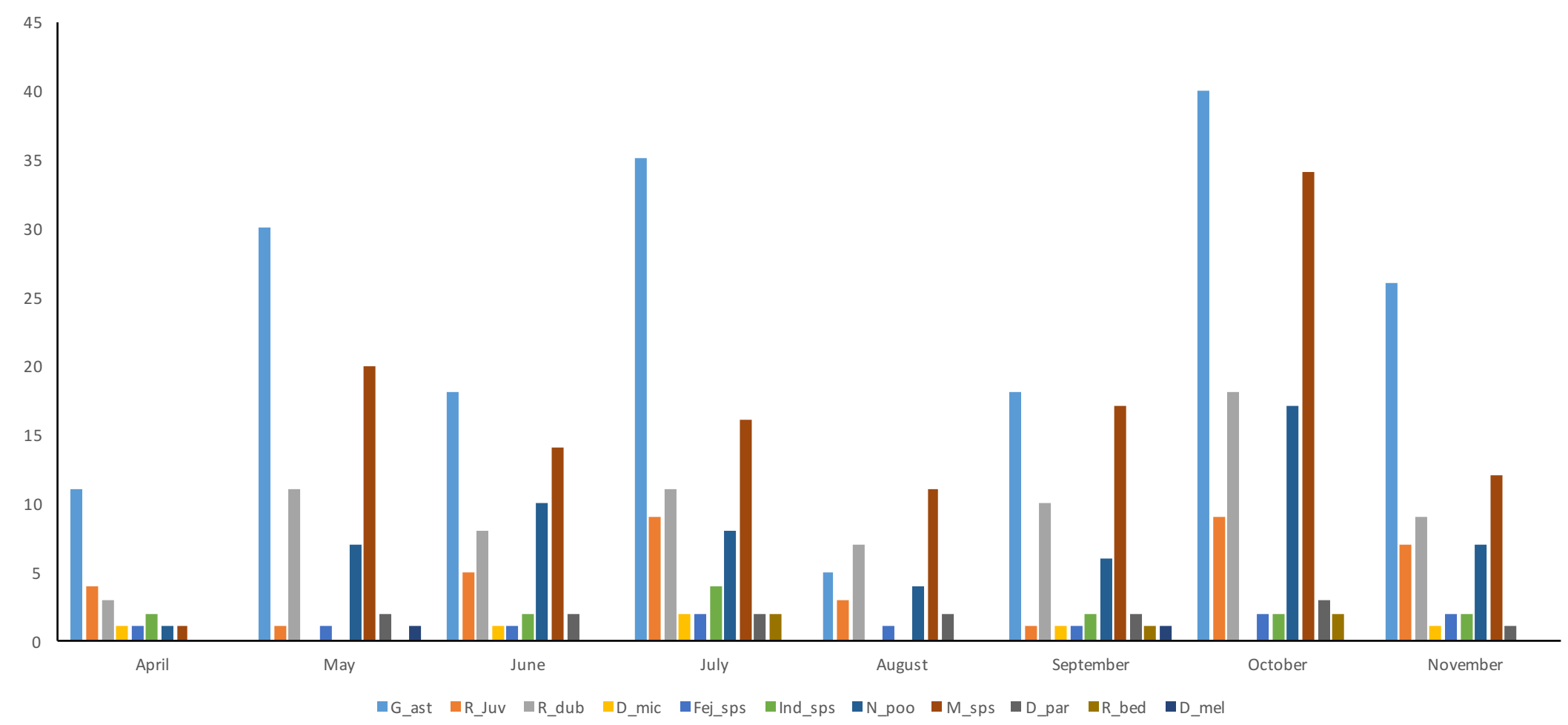

Figure 3.14. Species encountered per month in 2013 in stream transects. 


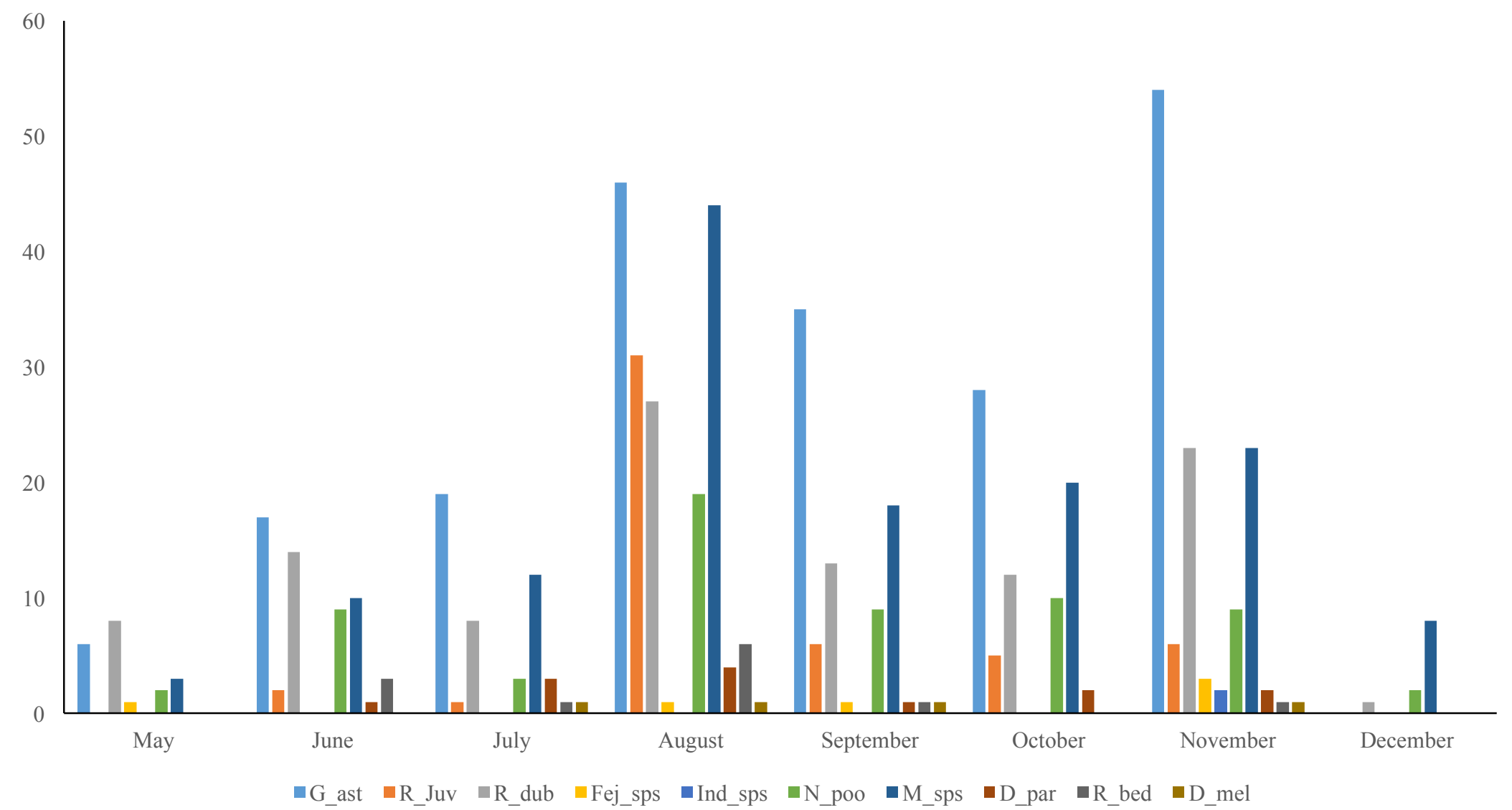

Figure 3.15. Species encountered per month in 2013 in stream transects. 


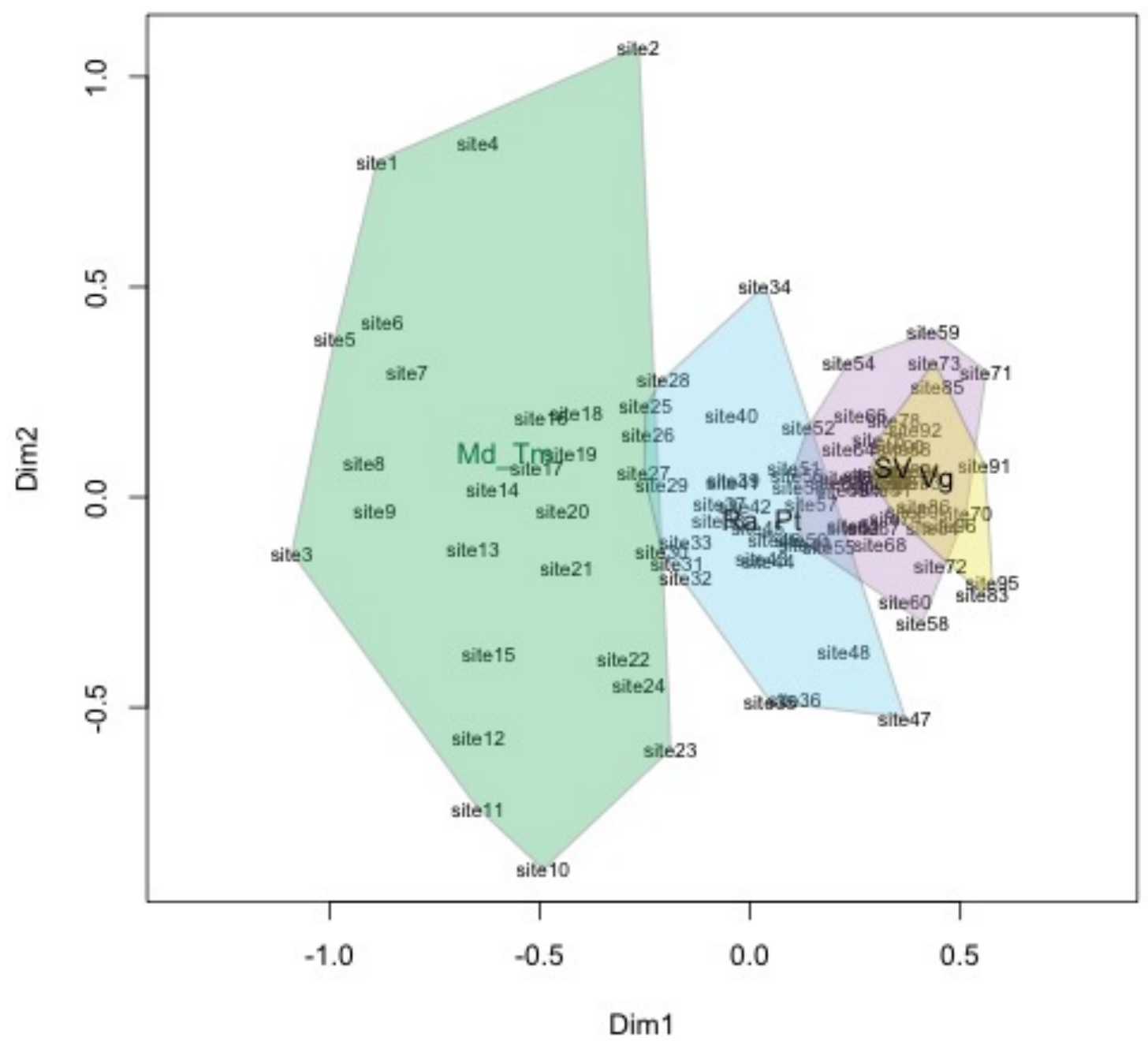

Figure 3.16. MetanMDS plot of similarity with ellipses drawn around the four different sites (Stress: 0.2510247). 


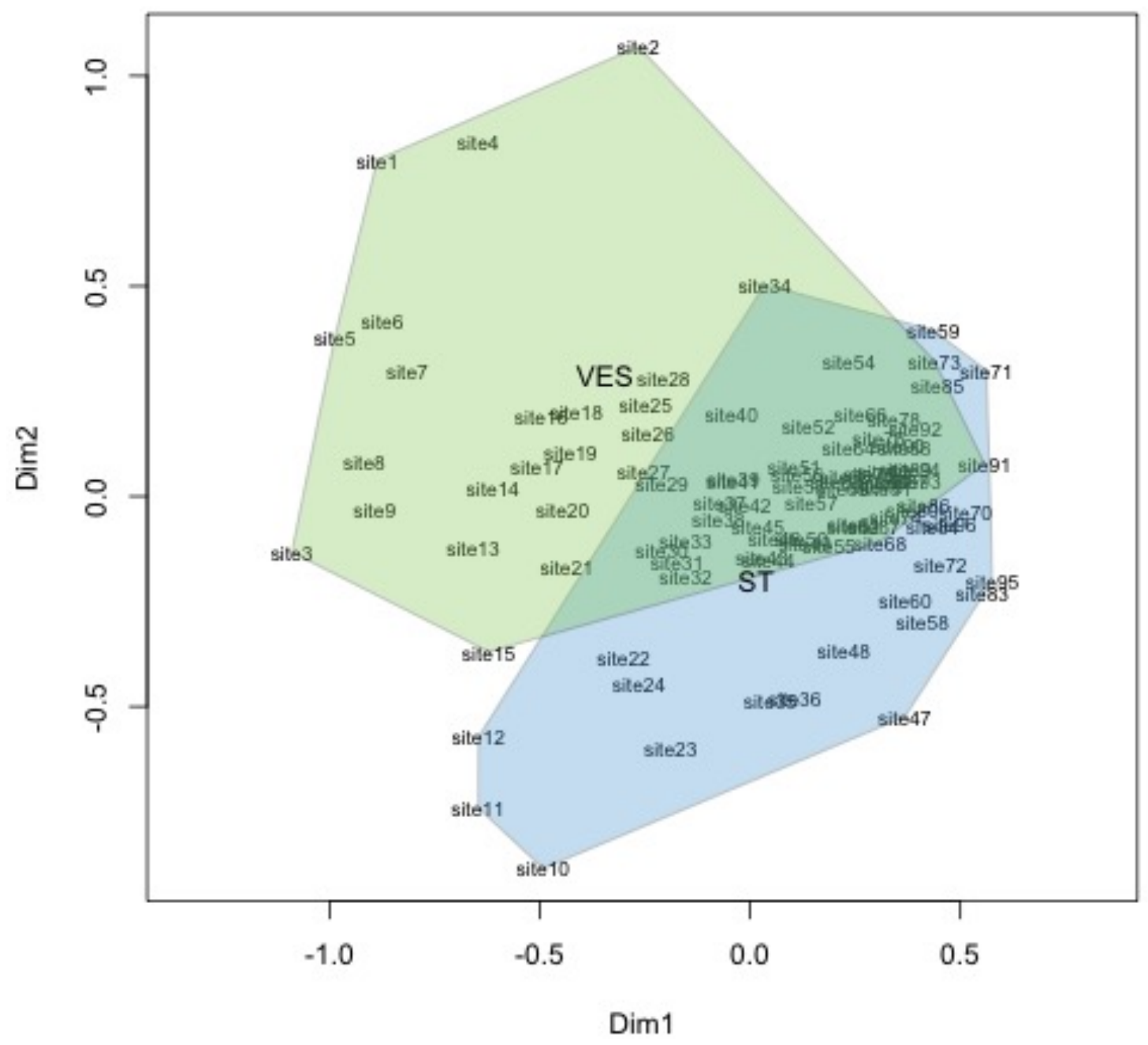

Figure 3.17. MetanMDS plot of similarity with ellipses drawn around the sites using either VES (light green) or stream transects (light blue; Stress: 0.2510247). 


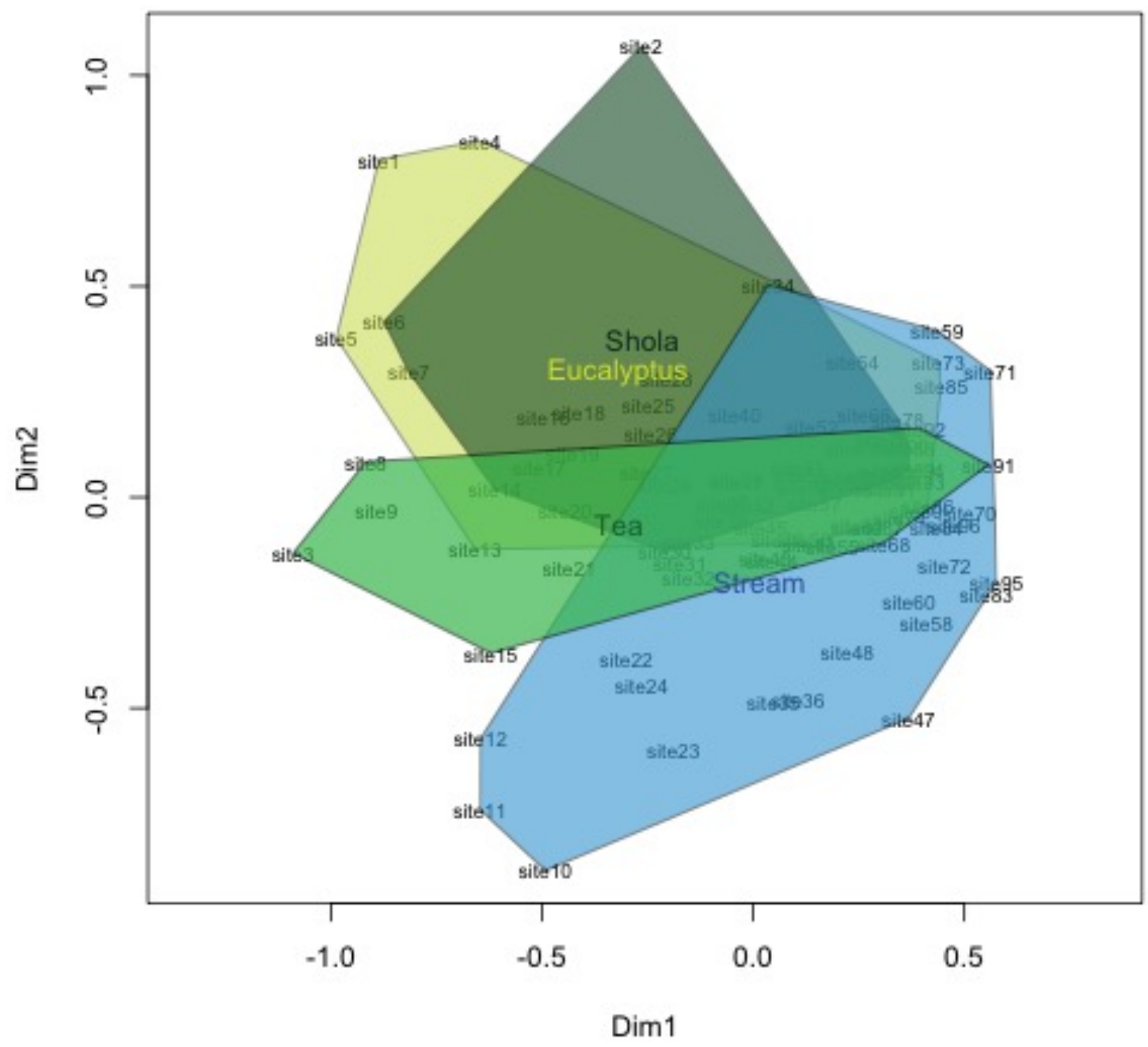

Figure 3.18. MetanMDS plot of similarity with ellipses drawn around sites from similar upland habitats, shola (dark green), tea (light green), eucalyptus (yellow), and around sites from stream transects (light blue; Stress: 0.2510247). 


\title{
V. CHAPTER 4
}

Testing for Chytrid Infection in Tea Plantations in the Southern Western Ghats, India

\begin{abstract}
With the recent declines in amphibian populations attributed to infectious diseases, it is imperative to monitor for the presence of disease causing fungi like Batrachochytrium dendrobatidis $(B d)$ in areas that do not show obvious mass declines of amphibians. In the present study, I swabbed anurans encountered in tea plantations in the southern Western Ghats. The site is located in the Sri Lanka and Western Ghats Biodiversity hotspot. I swabbed 216 individuals of 17 species, including four critically endangered species, between 2012 and 2015. Even though six samples showed amplification in simple PCR, none of them were positive for $\mathrm{Bd}$ in triplicate quantitative PCR experiments. Even though we report the absence of the Asian strain of $B d$ in Munnar, Kerala, using the PCR method, it is important to continue monitoring for the presence of chytrid and other infectious diseases. My study was conducted in a managed tea plantation that has regular application of fertilizers and fungicides. My data provide baseline information for the region. Future sampling and continued monitoring of frogs in this hotspot will help us manage amphibian populations in agricultural systems.
\end{abstract}


Keywords

amphibians, Batrachochytrium dendrobatidis, chytrid, swab, tea plantations, Western Ghats

Introduction

Mass extinctions have been periodic events on Earth, however each of the past five mass extinction events have taken place over very long periods of time as opposed to the current sixth mass extinction event (James et al. 2015; Wake and Vredenburg 2008). The current extinction rates are higher than any extinction event rate since 1980 and the extinction rates of amphibians are 136-2707 times greater than the background amphibian extinction rate (McCallum 2007). The IUCN World Conservation Union Global Amphibian Assessment (GAA) has shown that approximately 2,468 amphibian species $(\sim 43.2 \%)$ are experiencing some form of population decrease, and approximately $7.5 \%$ are critically endangered which exceeds the numbers for endangered birds or mammals (Stuart et al. 2004). The amphibian decline phenomenon refers to the global-scale enigmatic reduction in populations of several species of amphibians in North America, Central America, Europe, Australia, and other locations (Araújo et al. 2006; Berger et al. 2016, Collins and Storfer 2003; Daszak et al. 1999; Laurence et al. 1996, Lips 1999; Lötters et al. 2009; Pounds et al. 2006; Skerratt, et al., 2007). Since the early 1980s, scientists documented declines of amphibians in different parts of the world without any obvious cause (Alford and Richards 1999; Baringa 1990; Berger et al. 2016; Blaustein et 
al. 1994). During the first World Congress of Herpetology in 1989, scientists reported declines and the need to examine these supposed declines was discussed by herpetologists around the world (Baringa 1990; Lips 1998).

Initially all the drivers that were considered responsible for these declines included habitat change, pollution, deforestation, UV radiation, alien species, over-exploitation, and emerging infectious diseases (Alford and Richards 1999; Becker et al. 2015; Collins and Storfer 2003; Daszak et al. 1999). Extensive studies suggested that emerging infectious diseases, particularly chytridiomycosis, was responsible for many of these declines (Berger et al. 2016; Berger et al. 1998; Laurance et al. 1996; Lips 1998). Some of the tell-tale signs recorded were that these declines occurred suddenly, over a short period of time (as few as a few months), only adults seemed to be affected, no significant changes in environmental characteristics were noted over the period of the decline, stream-dwelling frogs seemed most severely affected, and mass mortalities were observed in some sites (Berger et al. 1999a; Laurance et al. 1966; Lips, 1999). The first scientific papers tying these declines to the fungus Batrachochytrium dendrobatidis were published in 1998 and 1999 (Berger et al. 1998; Berger et al. 1999a; Longcore et al. 1999). Berger et al. (1998) found no signs of fungal spores on specimens of frogs from museums in both Central America and Australia before the declines. Some claimed that amphibian populations were highly dynamic and that assuming that the declines were just a result of incomplete sampling without several continuous years of data was premature (Blaustein et al. 1994; Pechmann et al. 1991). Several scientists have since conducted 
extensive studies and associated $B d$ with reduced amphibian abundances in Central America, and suggested that these results can be extended to other regions of the world showing similar declines (Berger et al. 1998; Lips et al. 2006; Lips et al. 2008). Lips et al. (2008) modeled the movement of $B d$ from the upper reaches of Central America down, through Costa Rica and Panama, and were able to document the spatiotemporal movement of the fungus. They failed to find support for the climate-linked epidemic hypothesis of Pounds et al. (2006) that suggests that climate change was making amphibians more vulnerable to $B d$ (Pounds et al. 2006). Rohr and Raffel (2010) found that factors like climate change, and habitat loss might have increased the severity of $B d$ attacks on amphibians. Rohr and Raffel (2010) also showed how over $80 \%$ of amphibian declines could be explained by variables directly pertaining to temperature variations and El Niño dependent variables, and are correlated to global $B d$ related declines. Thus, showing that global climate change makes amphibians more susceptible to infectious diseases.

Co-infections of $B d$ with ranavirus in four species from Costa Rica were reported by Whitfield et al. (2013) and the same co-infections have been reported by Warne et al. (2016) from five species in Peru. However, neither paper provides support for the facilitation of one infection by the other. On the other hand, mesocosm studies by Becker et al. (2015) show that frogs from pristine temperate forests show higher $B d$ loads than those from disturbed tropical forests when inoculated with standardized Bd zoospores and suggested that deforestation or habitat loss might support faster $B d$ growth because of 
the added stress of habitat alteration. Becker et al. (2015) also reported that previous exposure to the fungus reduced the spore load on the naïve frogs than on frogs with prior exposure to $B d$.

After almost three decades of research, scientists are still concerned about the consequences of chytrid because it is a generalist fungus, that puts over $41 \%$ of the worlds amphibians at risk (James et al. 2015; Monastersky 2014; Skerratt et al. 2007; Swei et al. 2011). Batrachochytrium dendrobatidis is also reported from non-anuran amphibians from Africa, Japan, and Mexico (Frías-Alvarez et al. 2008; Goka et al. 2009; Gower et al. 2013; Lips and Donnelly 2005). The first conclusive demonstration of nonamphibian hosts of $B d$ were crayfish from Louisiana and Colorado; the study also demonstrated that healthy frogs were infected when exposed to water with infected crayfish (McMahon et al. 2013). Exposure of crayfish to different concentrations of Bd inoculated water caused increased rates of molting and then mortality in crayfish (McMahon et al. 2013). These observations need to be taken into consideration during conservation reintroduction plans. A study conducted at the La Selva Biological Station by Whitfield et al. (2007) showed declines in both reptiles and amphibians over a span of 35 years. Batrachochytrium dendrobatidis had only been reported to affect amphibians from mid-elevation sites and reptile declines were not expected. Whitfield et al. (2007), suggested that changes in leaf litter, along with increasing temperatures might explain the declines they observed. In a later study at the same site, Whitfield et al. (2012) detected $B d$ spores from anuran frog skin swabs taken in the coolest months of the year. 
Scientists are still debating about whether to call $B d$ a novel pathogen or whether the declines resulted from some abnormal change in an environmental variable that made amphibians more susceptible to the fungus (Skerratt et al. 2007). Another species of chytrid, Batrachochytrium salamandrivorans (Bsal), found only on urodeles was found during sampling in 2010 in Europe. Batrachochytrium dendrobatidis and Bsal are the only two species in the chytrid family of fungus that are known to affect vertebrates (Berger et al. 2016; Martel et al. 2012; Martel et al. 2013). Batrachochytrium salamandrivorans has a slightly lower optimal temperature range $\left(10^{\circ} \mathrm{C}\right.$ to $\left.15^{\circ} \mathrm{C}\right)$ than Bd (Martel et al. 2012). The new species of Batrachochytrium has been reported as the factor causing salamander population declines in the Netherlands (Martel et al. 2013).

Though several studies pin the declines of amphibians solely on $B d$ or Bsal, scientists now believe that synergistic effects with disease have accelerated this phenomenon of global declines (Berger et al. 2016; Lips 1998; Pounds et al. 2006; Sodhi et al. 2008; Whitfield et al. 2007). Sodhi et al. (2008) used multi-model Bayesian inferential statistics on information compiled for 5,717 species of amphibians and found that models including a combination of climatic seasonality, habitat degradation, and human effects seemed to predict population trends better any single driver. James et al. (2015) suggests that instead of looking at $B d$ hotspots, it might be time to shift our attention to $B d$ coldspots and try and understand the factors that prevent amphibians from being 
susceptible to the fungus in these areas and also predict which areas in the Americas are more susceptible to $B d$ and should be monitored closely.

Swabs from ten species of amphibians between 2010 and 2013 from the Seychelles Islands report no $B d$ present in representatives of the Order Anura and the Order Gymnophiona (Labisko 2015). Olsen et al. (2013) predicted that the Seychelles would affected by $B d$ soon (Olsen et al. 2013). Olsen et al. (2013) calculated areas that were likely to be $B d$ positive using a database with over 5000 samples (Figure 4.1). Olsen et al. (2013) also showed that the range of occurrence of $B d$ on amphibians has not reached an equilibrium infection status as there are still new locations where $B d$ is being reported from every year showing an extremely heterogeneous spatial spread of positive results globally. The Olsen et al. (2013) study also predicts the odds of chytrid being present in hylids in Asia as very high (Figure 4.3; Swei 2011). Hence, scientists in Asia are still testing new sites for the presence of this fungus and are closely monitoring old sites for the possible chance of novel chytrid fungus introductions (Figure 4.4; Swei et al. 2011).

Longcore et al. (1999) first cultured a pure line of the amphibian fungus Batrachochytrium dendrobatidis (henceforth referred to as $B d$ ) from a captive frog. The amphibian chytrid species (Phylum Chytridiomycota, Class Chytridiomycetes, Order Chytridiales) is a new species and was isolated from a Blue Poison Dart Frog (Dendrobates tinctorius) that was housed in the National Zoological Park, Washington DC. A close fungus to $B d$, Homolaphlyctis polyrhiza gen. et sp. nov, was recently 
described and its infection status has not yet been established (Longcore et al. 2012) suggesting that $B d$ is just one of the many members of the Chytridiales that could be infectious in nature. In the lab, cultures of $B s a l$ differed from those of $B d$ by the formation of germ tubes (Martel et al. 2013). Both these fungi from the order Chytridiales are aquatic and have flagellated zoospores used for transport (Berger et al. 1999a).

Most studies associating chytrid with amphibian declines have shown that the declines have taken place in species that are characterized by an aquatic larval stages (Figure 4.2) which is where they come in contact with the zoospores (Lips 1998; Collins 2013). Since anuran larvae lack a keratinized epidermis the tadpoles are not generally affected by the fungus except for their mouthparts which are keratinized (Berger et al. 1998; Berger et al. 1999b; McDiarmid and Altig 1999; Rachowicz and Vredenburg 2004). The dental ridges of the tadpoles are affected to different extents depending on the temperature and the extent of infection, and infected tadpoles are reservoirs and they all metamorphosed into infected adults (Rachowicz and Vredenburg 2004). However, it is uncertain if the fungus is lethal to larval stages or if the infections reduce larval feeding efficiency. Kobly et al. (2015a) reported that $76.1 \%$ of the times a swab from a leaf where a $B d$ positive frog was previously perching resulted in a $B d$ positive result. Hence, the transfer of $B d$ from the aquatic habitat to the terrestrial habitat could occur from recent metamorphs of species with aquatic larval stages and then infect terrestrial direct developing species, for example, species in the genus Craugastor (Bielby et al. 2008; Kobly et al. 2015a; Lötters et al. 2009). The presence of chytrid spores in rain drops in recent studies in Cusco, Peru 
suggests that strong winds and rain could help in the spread of $B d$ spores (Kolby et al. 2015b). High altitude and small geographic range are reported by Bielby et al. (2008) as the factors driving the relation between $B d$ positive, rapidly declining species and other $B d$ positive species. Nowakowski et al. (2016), proposed and successfully tested the idea that as mismatch in thermal tolerances of anuran hosts and $B d$ increased, the rate of $B d$ infection decreased. The zoospores of $B d$ mature and grow on the keratinized epidermis of amphibians and they might be able to survive as saprophytes on non-amphibian keratin (Longcore et al. 1999). Early studies showed that the colonies of $B d$ grew best at temperatures between $4^{\circ} \mathrm{C}$ and $25^{\circ} \mathrm{C}$, with the $\mathrm{pH}$ between 4 and 8 (Piotrowski et al. 2003). Stevenson et al. (2013) reported that different isolates of $B d$ from Australia showed different thermal tolerances (up to $28^{\circ} \mathrm{C}$ ) suggesting local adaptations in the isolates varied with local ambient temperatures. Recent work in Central America and Spain shows that the $B d$ load of individual amphibians is tightly connected with temperature (Berger et al. 2016; Fernández-Beaskoetxea et al. 2015; Whitfield 2011). The swabs taken from frogs in warm seasons had lower $B d$ loads than from frogs in cool areas and loads increased in the cool season when a favorable temperature range for $B d$ was obtained. Since the $B d$ fungus cannot sustain spore integrity at temperatures above $30^{\circ} \mathrm{C}$, when monitoring for $B d$, seasonality of the sampling needs to be taken into consideration (Johnson et al. 2003). Whitfield et al. (2012) show that there is a strong temporal affect on the $B d$ spore load on amphibians and the highest spore counts were obtained during the cold seasons at La Selva, Costa Rica which allow for the growth of temperature sensitive $B d$ spores. Experimental studies showed that holding populations of infected amphibians at $37^{\circ} \mathrm{C}$ caused the individuals to be cleared of the infections within 
16 hours (Woodhams et al. 2003). Zoospores of $B d$ were found to survive in water from a lake without a host for up to six weeks, for up to four weeks in tap water, and up to five weeks in deionized water (Johnson and Speare 2003). Researchers in Australia have reported a behavioral response to chytrid in which frogs were basking on rocks which killed the fungus (Danskin et al. 2011; Puschendorf et al. 2011; Rowley and Alford 2013).

Work by Chestnut (2014) showed that five different fungicides in varying concentrations inhibited the growth of $B d$ in culture temporarily, and that $B d$ started recovering from the effects of fungicide addition after 7 days and was equal to the $B d$ load in the control samples within 21 days. Chestnut (2014) also observed a difference in the growth rates of individuals over time under different treatments. Batrachochytrium dendrobatidis affects frog species differently; some merely play the role of carriers whereas others are killed by the fungus (Briggs et al. 2010; Lips 1999; Lips et al. 2006). The spores of $B d$ do not die when the host dies, but persist on the skin of dead amphibians and these spores remain dormant until another host is obtained (Longcore et al. 1999). The presence of $B d$ can be detected in two different ways: by histological examination of the skin or by genetic methods using Polymerase Chain Reaction (PCR) amplification. The environmental DNA (eDNA) from water or soil can also used to detect the presence of $B d$ in an area (Kolby et al. 2015a). The molecular method, though more expensive (\$13 per sample) than histological sectioning, is preferred, because PCR quickly quantifys the $B d$ load, i.e., the number of spores on a frog (Boyle et al. 2004; Kriger et al. 2006a). Quantification of 
$B d$ zoospores can be done accurately using the histological sectioning method which are 2.46 times less expensive than the swabbing but it requires killing of the adult frog, as shown by a direct comparison of costs by Speare et al. (2005). However, counting individual spores on histological slides to assess $B d$ load is a cumbersome process. A study comparing these two techniques shows that the Taqman PCR procedure is much more efficient at detecting $B d$ and it is more ethical as it only involves swabbing the skin of frogs as opposed to harvesting the entire individual (Kriger et al. 2006a).

Recent studies by Farrer et al. (2011) have shown that there are three distinct lineages of $B d$ : BdGPL (found globally), BdCAPE (from South Africa), and the BdCH (from Switzerland). The BdGPL lineage seems to be recent and its emergence occurred at the same time that declines of amphibians were reported in North and Central America, Europe, Australia, and elsewhere (Farrer et al. 2011). The BdGPL lineage seems to be hyper-virulent and bears all the signs of a recombinant lineage because of short sequence length overlaps with several other strains (Farrer et al. 2011). The chance of such recombination occurring between such widely spread strains was probably assisted by the international trade in amphibians and reptiles (Farrer et al. 2011; Laurence et al. 1996). A study from South Africa predicts the regions that have an increased likelihood of $B d$, determined on only positives samples from all over South Africa, which is important from a monitoring perspective, even though there are no clinical symptoms in any of these populations currently (Tarrant et al. 2013). Scientists believe that trade in amphibians especially, Xenopus laevis, a frog used for pregnancy testing, and Lithobates 
catesbeianus (used as food) might have resulted in the recombination of the harmless or non-virulent strains of $B d$, to result in the formation of the virulent killer fungus (Mazzoni et al. 2003; Parker et al. 2002; Weldon et al. 2004). Some researchers suggest that the difference in susceptibility to $\mathrm{Bd}$ is tied to innate immunity to $B d$ in certain species, whereas another school of thought states that the immunity to $B d$ is acquired because amphibians are known to have a cocktail of peptides or other compunds stored in their glands that are known to have antibiotic like synergistic effects on fungi and bacteria (Richmond et al. 2009; Rollins-Smith and Conlon 2005; Woodhams et al. 2006; Woodhams et al. 2007). Tadpoles with $r$ and $g$ haplotypes are more resistant to $B d$ than others, and resistance is determined by the presence of particular Major Histocompatibility Complexes (MHC) (Barribeau et al. 2008, McMahon et al. 2014). Anaxyrus quercicus, Osteopilus septentrionalis, and Litoria booroolongensis were shown to actively avoid $B d$ inoculated areas, as well as show a reduced infection rate when exposed to dead cultures of $B d$ before being inoculated with live $B d$, showing the development of active immunity to the fungus (McMahon et al. 2014). In a detailed study on $B d$ infected frogs with symptoms, infected frogs without symptoms and uninfected control frogs of the species Lithobates yavapaiensis, Savage et al. (2016) reported an increase in the blood neutrophil to lymphocyte ratio in the $B d$ infected frogs, which is similar to a response shown during infection or stress. A decrease in the growth rate of infected individuals compared to the control group was also reported, even though the food intake was uniform in all groups (Savage et al. 2016). Savage et al. (2016) suggest that infected individuals might show prolonged tolerance to $B d$, to buy enough time for their body's adaptive immune response to start functioning. An earlier study by Savage 
and Zamudio (2011) suggested that frogs with the Major Histocompatibility Complex Q (MHC Q) and frogs which are MHC heterozygotes in general appear to show significantly reduced risk of death when exposed to Bd. Bataille et al. (2015) reported that the MHC binding pockets of three MHC-II antigen binding pockets (four, six, and nine) in 17 species of amphibians that survived $B d$ infections showed similar amino-acid binding conformations (Bataille et al. 2015), suggesting a similar global fingerprint for $B d$ resistant anurans; the presence of specific antigen binding pockets remains to be tested in additional $B d$ resistant species. Woodhams et al. (2007) showed that the survival rates after ex-situ infection of four different species (Litoria caerulea, Litoria chloris, Mixophyes fasciolatus, and Limnodynastes tasmaniensis) of Australian amphibians were different (Lit. caerulea and M. fasciolatus suffering 95\% mortality) and that the species (Lit. chloris and Lim. tasmaniensis) with the highest resistance to mortality showed the presence of skin peptides secretions in larger quantities than the others. Melzer and Bishop (2010) found that four native species of leiopelmatid frogs in New Zealand were more resistant to $B d$ and produced more skin secretions than two naturalized Litoria species. Leiopelma archeyi, which was reported to have an $88 \%$ decline in five years was found to produce the largest quantity of peptide skin secretions (Melzer and Bishop 2010). When three different strains of $B d$ were used to infect frogs in a study, the individuals of all species died, however the time to mortality was very different for each of the strains showing that each strain of the fungus had a different intensity of infection (Berger et al. 2005). Therefore, the success of treatment of the infected populations can depend on the initial susceptibility of the species in question. 
Harris et al. (2006), isolated several bacteria from 10 genera, from the skin of two amphibian species that showed $B d$ inhibition in ex-situ tests. Scientists showed that the addition of the anti-fungal bacterium found on amphibian skin, Janthinobacterium lividum, to amphibians infected with chytrid reduced the mortality associated with the infection (Harris et al. 2009). Bataille et al. (2016) showed that the microbiome of captive versus wild caught species of amphibians differed, as did the diversity between the dorsal and ventral communities in both groups. The difference in microbial communities could drive the presence of different peptide complexes on amphibians (Bataille et al. 2016). A study from Panama reported five frog species sharing a larger number Operational Taxonomic Units (OTU) of microbes between their body swabs and perch swabs, than having unique OTU's either from their body swabs or from their perch swabs (Rebollar et al. 2016). Rebollar et al. (2016) also reported that individuals of Craugastor fitzingeri found in $B d$ naïve places had a higher microbial diversity than individuals from places which had endemic $B d$ populations, suggesting that historical microbial data from amphibians may have played a role in the biogeography of the infection patterns of $B d$. Lubick (2015), reported clearing a wild population of toads of chytrid on the Spanish island of Mallorca. Scientists are still trying to understand the links between the innate and acquired immunities that seem to cause different infection patterns of Bd in different species (Richmond et al. 2009). 
An in-vitro study by Voyles et al. (2014) showed an increase in rates of zoospore formation and general population growth rates in two lineages of $B d$ that were diluted 10 and 50 times, respectively. Though there was no significant difference in the infection patterns of the two cultures, it is still important to consider differences in growth rates and spore formation, when storing $B d$ in culture (Voyles et al. 2014) and as well monitoring its evolution in the wild. Thus the global amphibian decline phenomenon has brought together a community of biologists, all trying to understand the drivers of these declines and a discover a way to reverse these declines.

Though sampling for $B d$ has been conducted on a large scale globally, Asia has been underrepresented in sampling for the presence of chytid (Swei et al. 2011). Une et al. (2008) reported the first case of $B d$ in Asia, from a consignment of 45 frogs, with $B d$ reported from 9 of 18 species ( 27 out of 45 individuals) in a private pet collection. Following this finding, Goka et al. (2009) conducted sampling in Japan of native and exotic amphibian species, both in captive and wild condition including 265 from pet shops (3 native species and 15 non-native species), 294 (17 native species and 58 nonnative species) bred in-situ and 2103 (47 native species and two non-native species) collected from the field, and they found positives for Bd in Ceratophrys cornuta, Ceratophrys ornate, Lepidobatrachus laevis, Lithobates catesbeianus, Xenopus laevis, Afrixalus fornasinii, Ambystoma sp., Laurasiarana ornativentris, and Andrias japonicus. For both captive and wild amphibians, 26 different haplotypes of the ITS1-5.8S-ITS2 region of $B$. dendrobatidis were found, including three specific to the Japanese giant salamander (Andrias japonicas). The species used in pet trade (Lithobates catesbieanus) 
and for Biology classroom education (Xenopus laevis) were the two hosts with the largest number of Bd haplotypes (Goka et al. 2009), and since the incidence in the wild species was low, the authors suggest a major role by these two introduced species in the spread of Bd. Yang et al. (2009) reported the first observation of $B d$ from wild amphibian populations of three species (Bufo gargarizans, Hyla japonica, and Lithobates catesbianus) in South Korea. Again, as in the case of Japan, Lithobates catesbianus, an introduced free-ranging species, had most of the $B d$ positive samples. However, none of the swabbed individuals tested showed outward signs of chytridiomycosis which suggested that this exotic species was not succeptible to the strain of $B d$ in Korea. Kadekaru et al. (2015) showed that 20 out of 21 tadpoles of Lithobates catesbianus with abnormal mouth lesions tested positive for $B d$. Chytrid was first reported from Indonesia in four amphibian species in the early part of the $21^{\text {st }}$ century (Rhacophorus javanus, Chalcorana chalconota, Leptobrachium hasseltii, and Limnonectes microdiscus) by Kusrini et al. (2008). Three of these were found in streams and the fourth species was found near a stream. The tadpoles of Leptobrachium hasseltii, with thin keratinous dental ridges were found in the streams from which the adults were swabbed (Kusrini et al. 2008). In 2012, individuals of Bombina orientalis, Cynops orientalis, Paramesotriton hongkongensis, and Xenopus laevis obtained from import stock in Hong Kong, were shown to have low $B d$ loads (Kolby et al. 2014). The authors also reported low $B d$ loads from water samples takes from containers transporting these amphibians, raising concerns about spreading $B d$ infection through the improper disposal of water by the pet trade industry (Kolby et al. 2014). Since Hong Kong is a large center for the amphibian pet-trade industry, reports of $B d$ from captive amphibians here, is a matter of global 
concern. Bai et al. (2010) first reported $B d$ from mainland China from four species (Lithobates catesbeianus, Laurasiarana chaochiaoensis, Babina pleuraden, and Odorrana andersonii). Later, Bai et al. (2012) reported the presence of 30 haplotypes of $B d$ from China in both wild caught and captive species, with Lithobates catesbieanus showing the highest prevalence of $B d$. Laurasiarana dybowskii, which is intensively hunted for human consumption was reported to be $B d$ free by Wei et al. (2010).

The presence of unique $B d$ lineages to Asia, as suggested by Swei et al. (2011) is also supported by the study by Bai et al. (2012) with the identification of a haplotype that is unique to the Chinese endemic, Babina pleuraden. Several other studies have since confirmed the presence of $B d$ in China (Zhu et al. 2014; Zhu et al. 2016). Vörös et al. (2012), reported the first record of $B d$ from Thailand from a single individual of the species Ingerophrynus parvus $(\mathrm{n}=6)$, that did not show any external signs of infection. Savage et al. (2011), reported low $B d$ loads from four families (Megophryidae, Microhylidae, Ranidae, and Rhacophoridae) of amphibians from Malaysia with no external symptoms of chytridiomycosis, again suggesting that there might be a native strain of $B d$ in Asia. Fong et al. (2015) detected the presence of $B d$ spores in skin sections from formalin fixed species of amphibians from the 1910-1929 (Korean Peninsula). Yumi et al. (2010) also reported the detection of $B d$ spores in skin sections from amphibian samples from 1902 to 1937 in Japan. The detection of $B d$ spores in amphibian specimens when no reports of chytridiomycosis, supports the hypothesis of the presence of native non-infective, $B d$ haplotypes in Asia. Zhu et al. (2014) reported the observation 
of low $B d$ spore counts from six out of 67 museum specimens between 1930-1939. A large sample of 3363 amphibians (Anura=3315; Caudata=48) from 15 Asian countries, reported an overall $B d$ prevalence rate of $2.35 \%$ with positive samples (greater than 1 genomic equivalent of $B d$ ) from Indonesia, Kyrgyzstan, Laos, Malaysia, Philippines, and South Korea (Swei et al. 2011). None of the samples from the Order Caudata were positive for $B d$ but they were not tested for the presence of Bsal (Swei et al. 2011). Labisko et al. (2015), reported the absence of chytrid in samples from the Orders Anura, and Gymnophiona from 291 individuals from the Seychelles Islands. Bataille et al. (2013) reported that 11 out of 17 South Korean species had a Bd prevalence between $12.5 \%$ and $48.0 \%$. The exotic species Lithobates catesbeianus had a prevalence of $24.7 \%$ (Bataille et al. 2013). On the basis of multi-locus genotyping, three of the 50 known haplotypes of $B d$ from South Korea were unique and different from the globally emerging recombinant lineage ('Bd-GPL'), as well as, from the Brazilian $B d$ Lineage (Bataille et al. 2013).

The presence of such large variations in the $B d$ haplotypes suggests that there have been several complex interactions between the native $B d$ lineages, and the globally ubiquitous Bd-GPL strain (Bataille et al. 2013). Batrachochytrium dendrobatidis was also reported from 19 out of 105 sample from lakes across Turkey with the positive samples from four amphibian species (Pelophylax ridibundus, Hyla orientalis, Pseudepidalea variabilis, and Pelophylax caralitanus) found in seven water bodies (Erismis et al. 2014). Although Bataille et al. (2013) reported a higher prevalence of $B d$ than Swei et al. (2011), the 
Bataille group did not notice any outward signs of infections in the individuals sampled from South Korea and suggested that that particular haplotype of $B d$ might be endemic to the country. Batrachochytrium dendrobatidis has not been detected from the low-lying plains of northwest Borneo by Kaiser and Grafe (2011) or from the swabs from the United Arab Emirates (UAE) in both captive and wild samples (Soorae et al. 2012). Absence of $B d$ in Borneo and UAE may be the result of unfavorable high temperatures for the survival of $B d$. No positives were reported in a study of $B d$ in Vietnamese salamanders, however, experimental ex-situ inoculations led to infection and death with three weeks, suggesting that this species is very susceptible to $B d$ infections (Thien et al. 2013). These studies did not test for the presence of Bsal.

The first studies of $B d$ in India reported that there was no $B d$ in histological samples of seven wide spread and commonly found amphibian species (Duttaphrynus melanostictus, D. stomaticus, Hoplobatrachus tigerinus, Euphlyctis cyanophlyctis, Fejervarya limnocharis, Polypedates maculatus and Uperodon systomus) from the state of Gujarat, however, no information on sample size was reported and only the tissue histology method was used (George et al. 2008). Duttaphrynus melanostictus, D. stomaticus, Polypedates maculatus, and Uperodon systomus are mostly terrestrial and arboreal species, while Hoplobatrachus tigerinus, Euphlyctis cyanophlyctis, and Fejervarya limnocharis are aquatic. The histological method does not quantify the spore load. The absence of $B d$ in Gujarat could be explained because the average maximum temperature in Gujarat is above the maximum temperature at which $B d$ is viable $\left(30^{\circ} \mathrm{C}\right)$ for 10 months 
of the year. Nair et al. (2011) reported one positive sample of the Asian $B d$ strain in one frog (Indirana brachytarsusous: Family Ranixalidae) out of 142 samples from eight species from the Western Ghats in India. The authors report that the chances of a false positive are low since the positive was tested by two independent laboratories and suggest that such low rates of positives are not unique to the Western Ghats. Dahanukar et al. (2013) report the presence of an Asian strain of $B d$ from three species, Nyctibatrachus humayuni, Indirana leithii and Raorchestes bombayensis found in the northern Western Ghats on the basis of eight positive samples. Dahanukar et al. (2013) used diagnostic nested PCR, quantitative PCR, DNA sequencing, and histopathology. They reported external clinical symptoms in one of three species (Nyctibatrachus humayuni) suggesting that the Asian strain may not be lethal to at least two species (Dahanukar et al. 2013). Studies by Molur et al. (2015) report the presence of the generic Asian $B d$ strain in eight individual samples from eight different species from a total of 497 samples representing 22 different genera. They tested for $B d$ with nested PCR and the positive samples were tested in two independent laboratories.

Since the number of $B d$ monitoring studies in India are few and mostly from protected areas, I wanted to check for the presence of $B d$ in tea plantations in southern Kerala. I swabbed anurans using standard methods, in tea plantations in Munnar, India, to determine if $B d$ was present in this region of the southern Western Ghats. Since, there have been no mass die-offs of anurans reported from the Western Ghats, we predicted that all of ours samples would either test negative for $B d$ or if any of them test positive 
for $B d$, we predicted that the spore load will be minimal. The study site is located in the Western Ghats and Sri Lanka Biodiversity Hotspot. Sampling was done for four years we ensured that sampling was done during months with lower temperatures (November and December). For the current study, swabs from 216 anurans were collected from four tea estates near Munnar, India from November, 2012 to December, 2015.

\section{Study Area}

The swabbing was conducted in the Kanan Devan Hills Tea Plantation Company Private Limited $\left(10^{\circ} \mathrm{N}\right.$ and $\left.77^{\circ} \mathrm{E}\right)$ located in the Idukki district, of Kerala, in the southern Western Ghats. The company owns $240 \mathrm{Km}^{2}$ of land, and $100 \mathrm{Km}^{2}$ of which is under tea cultivation (Figure 4.5). The landscape has undulating hills and ridges that run from the northeast to the southwest direction. The altitude varies from $600 \mathrm{~m}$ above sea level (asl) to $2695 \mathrm{~m}$ asl. The highest point in the park (2695m), Anamudi (Elephant Peak), is the highest peak in peninsular India. Though located in the tropical belt, the climate in this area is temperate because of its altitude. Munnar receives rainfall both during the Southwest and the Northeast monsoons. The Southwest monsoon accounts for over 80 percent of the annual precipitation and occurs during June and July, and the rest of the precipitation is received during the Northeast monsoon which extends from October to November (Figure 4.6). The minimum temperature in the study period was $0^{\circ} \mathrm{C}$, and the maximum temperature was $29^{\circ} \mathrm{C}$. The humidity in these areas is high year around, usually above $80 \%$. The area has wet evergreen, semi evergreen, moist deciduous, dry deciduous, 
broad-leaved hill forest, montane wet temperate forest and grasslands according to the revised classification by Champion and Seth (1968).

\section{Methods}

Field Protocol for Swabbing Frogs

Time constrained and opportunistic surveying were used to find the anurans for swabbing in five estates, Kanniamallay, SilentValley, Madupatty, Rajamallay, and Vagavurrai (Figure 4.5). Swabs (IACUC-13-034-CR01 and IACUC-15-041)were taken from all the species that were encountered and individuals were swabbed using standard methods to obtain the material required for detection of the Bd fungus. Swabbing was conducted between 19:00hrs and 23:00hrs. Sampling was done in all available habitats in the tea plantations (tea, eucalyptus, shola forests, streams, along roads, as well as around human settlements). Each individual was handled with a new pair of sterile gloves and the standardized technique by Kriger et al. (2006a) was used to swab animals. For each sample, a new cotton swab was run firmly first along the dorsal surface, then along one lateral surface, then along the ventral surface, on the ventral surface of inguinal region and then along webbing of one of the legs of the frog (Kriger et al. 2006a). Each swipe was repeated five times on each of the body surfaces specified. No cross contamination between samples occurred. Each sterile swab was then placed in an individually labeled vial for analysis. The snout-vent length and weight for each of the swabbed individuals was measured using Vernier calipers $(0.05 \mathrm{~mm}$ least count) and a spring balance $(0.5 \mathrm{~g}$ least count), respectively. The condition of the skin of the frog was noted. The plastic 
waste generated during the swabbing process (gloves and covers of the swabs) was carried away from the site and disposed of elsewhere. The samples were stored in a freezer $\left(-4^{\circ} \mathrm{C}\right)$ until they were transported to the Laboratory for Conservation of Endangered Species (LaCONES), in Hyderabad, where the samples were analyzed.

Laboratory protocol for swab processing

The DNA extraction was done by adding 300uL of Extraction Buffer (Table 4.1) into a $2 \mathrm{~mL}$ micro-tube. The tips of the swabs were cut so that they entered the tubes. Three tungsten carbide beads (Qiagen) $(3 \mathrm{~mm})$ were added to each tube and bead beating was conducted for 150 seconds using a Qiagen tissue lyser. The tubes were centrifuged and then swabs were removed from the tube following further centrifugation (Goka et al. 2009). The supernatant was pipetted into new Eppendorf tubes and $20 \mu l$ of crude DNA was taken and diluted with $180 \mu 1$ of deionized water (Goka et al. 2009). This diluted DNA was used as templet for PCR.

The Polymerase Chain Reaction was performed in a 10ul reaction volume by using EURx master mix (Table. 4.2) containing 1ul of template, 5 picoMolar of each forward and reverse $B d$ specific ITS1-5.8S-ITS2 gene primers Bd a (5'- CAG TGT GCC ATA TGT CAC G-3') and Bd b (5'- CAT GGT TCA TAT CTG TCC AG - 3') and nuclease free water. The PCR results were visualized on a 2\% agarose gel. Qualitative PCR was performed using the $B d$ specific primer, ITS1-5.8S-ITS2 gene primers $B d$ a (5'- CAG TGT GCC ATA TGT CAC G-3') and $B d$ b (5' - CAT GGT TCA TAT CTG TCC AG - 
3') and the Taqman MGB probe designed by Boyle et al. (2004). Single sample qPCR was performed first (Kriger et al. 2006a). Samples showing amplification were then repeated in triplicate qPCR reaction. Samples were considered positive for $B d$ only when more than one out of the three replicates showed amplification. Qualitative PCR for $B d$ was done by using the protocol outlined by Boyle et al. (2004) and later modified by Kriger et al. (2006b).

Results

I obtained 216 samples from 17 species of anurans known to occur in the region. The individuals were swabbed between 2012 and 2015 (Table. 4.3). These include the critically endangered species Raorchestes griet, Raorchestes munnarensis, Rarochestes chlorosomma, and Rhacophorus pseudomalabaricus (Table. 4.4). The threat status allocated by the IUCN Red-list for eight of these species was either data deficient or not evaluated. Eight of the 17 species were from the family Rhacophoridae represented by the genera Raorchestes (six species), Rhacophorus (one species), and Ghatixalus (one species). Ghatixlaus asterops was the most represented species with 31 samples, this species was encountered perched on vegetation in slow flowing streams (Table. 4.5). In the 216 samples, only six samples showed amplification with simple PCR, and on further processing with pPCR in tri-replicate, none of the samples showed a positive result. Since all the samples showed up as negative, the prevalence of $B d$ in the Munnar region of the southern Western Ghats is reported to be zero. Throughout the period of the study the visual appearances of the frogs were noted and abnormalities or skin wounds were not 
observed. The lowest temperature recorded when swabbing was $8^{\circ} \mathrm{C}$ and the highest temperature recorded was $26^{\circ} \mathrm{C}$ (Figure 4.7) which coincides with temperatures favorable for $B d$ growth. The largest number of samples are from the month of December and the fewest from the month of April (Figure 4.8) this is because swabbing was not uniformly distributed across the months and effort was taken to swab during December, to test for the presence of $B d$ in winter.

\section{Discussion}

My study showed that over a period of four years $B d$ was not present in 17 species of anurans near Munnar in the Western Ghats. The species I sampled included aquatic and terrestrial species, as well as several direct developing species from the genus Raorchestes. The daily minimum temperatures in Munnar are lower than those in the plains by $10^{\circ} \mathrm{C}$, however, the highest temperature during mid-day exceeds the optimal range for $\mathrm{Bd}$, throughout the majority of the year, except for a few days in late December.

A study conducted in Nevada, showed that two species of amphibians had $B d$ spores with load levels which can be damaging even when the day time temperatures were as high as $32^{\circ} \mathrm{C}$ (Forrest et al. 2015). The authors suggest that even though the air temperature, is high the amphibians never reach such temperatures because of their nocturnal habits and aquatic habitat (Forrest et al. 2015). Because temperature has a major influence on growth and survival of the $B d$ fungus, the temperature at our study sites might be one of 
the explanations for why Munnar has not suffered a mass die-off of amphibians. Daniels (2003) suggested that a possible explanation for the absence of any visual skin deformities of anurans in the tea plantations, in his study could be the regular application of fungicides which are directed at Blister Blight, caused by a fungus that damages tea production (Daniels 2003). Munnar in the Western Ghats, a biodiversity hotspot, is a site where several new amphibian species are waiting to be described. Although there are reports of a few positives $B d$ samples, there have been no mass die-offs of amphibians reported from any part of the country (Dahanukar et al. 2013; Molur et al. 2015). These studies suggest that the Asian $B d$ strain many not be as lethal as other strains. The Asian strain may not be as virulent as other strains, or the lack of infection could be because $B d$ is temperature limited in most parts of India as the daily temperature regularly exceeds $24^{\circ} \mathrm{C}$. Even though the general trend of declines because of $B d$ are not seen in the Indian subcontinent it is critical to monitor frogs to assess their infection status.

Since fungi like $B d$ are reported to be extremely dynamic (Olsen et al. 2013; Swei et al. 2011), strains that currently infect anurans but show no symptoms of visible infection in amphibians may mutate into ones that are more infective that the strains already found in the community or infective strains of $B d$ may be introduced into a naïve community of amphibians causing mass die-offs. Swei et al. (2011), suggest that the reasons for low $B d$ prevalence in Asia are 1) $B d$ is not yet established 2) $B d$ and the anurans in Asia have coexisted and hence, it does not cause a threat to the amphibians here and 3) $B d$ is inhibited by some biotic or abiotic factor that scientists are yet to understand (Figure 4.4). Goka et 
al. (2009) report the detection of $B d$ in old formalin fixed specimens of $A$. japonicas from 1901, suggesting that the $B d$ haplotypes found in Japan are probably native to Japan and have existed with amphibians in Japan from several hundred years, explaining why there have been no massive die-offs reported from the country. The Japanese pattern is very different from the studies of amphibian from the New World and Australia (Berger et al. 1998.). Several of the $B d$ positive individuals in Asia have haplotypes that are mixes between the globally emergent $B d$-GPL strain and other native strains suggesting that the pet trade industry may play a role in the global spread of $B d$. In addition, to the presence of several haplotypes of $B d$, the new threat of Batrachochytrium salamandrivorans, a fungus found in European salamanders (Martel et al. 2013) gives us reason to be concerned about the spread of these fungi globally. In January of 2016 the US Fish and Wildlife Services added 20 genera of salamanders to their list of injurious wildlife species, as a preemptive measure to prevent the spread of Bsal to the United States. The synergistic action of humans, climate change, habitat loss, and fragmentation are difficult to quantify though a few studies have shown that humans have added to the pressures on amphibians (Venesky et al. 2014). A review of $B d$ cases in South America showed a steady decline in the lag times between the first detection of $B d$ and mass declines of amphibians at a site (Philips and Puschendorf 2013) suggesting that $B d$ may become increasingly virulent with time. With a life-cycle of approximately 61 days, it is likely that $B d$ is undergoing mutations each generation, whether or not these mutations in the fungus are directly correlated to increased rates of amphibian population declines remains to be seen (Philips and Puschendorf 2013). 
Scheele et al. (2014b) put forth a detailed management plan to tackle $B d$ spread and mitigation. The plan included suggestions for prevention, treatment, and increasing resilience in case of $B d$ infections, both long-term and short-term. While some of management ideas are harder to implement globally than others (translocation to $B d$ free areas), where some suggestions such as prevention of infection in captive population by thermal manipulation are more feasible options. Whitfield et al. (2016) put forward 11 suggestions for the future management of chytrid in Central America and these recommendations are applicable globally; further research in amphibian life history and disease, researching interactions of amphibian stressors, $B d$ reduction plans, identification and protection of rare species, starting long-term research, establishing captive seed populations, and most importantly developing a viable long term conservation policy. Though these are directed for Central America, they would work well in other parts of the world.

In the last two years, more than one group of scientists have agreed that it might be more important to study $B d$ coldspots and understand what makes some species more resistant to $B d$ than others, than to study $B d$ hotspots (James et al. 2015; Mendelson 2011). These coldspots could be areas of high prevalence of $B d$ but low negative impacts on native populations which makes the study of the innate and acquired immunity of the amphibians in these areas important from a conservation perspective (James et al. 2015). The recolonization of the Australian species Litoria verreauxii verreauxii, in old habitats and those rich with wooden debris, 16 years after $B d$ caused declines is a sign that there is 
hope that $B d$ affected species may recover, albeit at different rates (Scheele et al. 2014b). The emergence of generalist fungi and their spread over the decades warrants the constant monitoring for the presence of novel infections in amphibians around the world (James et al. 2015). Alroy (2015) reported that approximately 200 species (3.1\%) of amphibians have gone extinct since the 1970 s and that we might lose another $6.9 \%$ of our amphibian diversity in the next century if we continue at the same extinction rate. With herpetologists focusing on how to reverse the current trend of global amphibian declines, it is imperative to try and formulate several strategies that attach the primary driver of these declines (Scheele et al. 2014a). Fundamental to these strategies is to test and monitor sites that do not show mass amphibian declines yet, ex-situ sites where species can exist without exposure to $B d$, and gradual increasing of immunity of native populations to $B d$ strains (James et al. 2015; Scheele et al. 2014b). In times of global concern because of declining amphibian populations it is especially important to check and keep monitoring areas for the presence of infectious diseases on a regular basis. With emperical information we should continue to monitor known populations. It is only by a combination of several methods that we may be able to revert the current trends of amphibian declines.

Acknowledgments

I thank Florida International University for a graduate assistantship which allowed for data collection. I thank the Wildlife Institute of India, Dehradun, India and Dr. Karthikeyan Vasudevan for the Research Associate post provided from 2012 to 2015. 
LME thanks the KDHP Private Ltd. for permission to work on the tea plantation property in Munnar, Kerala and I also thank Elangovan (Tribal Field assistant) for help with field work. Karthikeyan Vasudevan and Milind Mutnale helped with the laboratory work with a grant supported by the Department of Science and Technology, India. Laboratory for Conservation of Critically Endangered Species, Hyderabad provided the resources and space to analyze the Bd swabs.

\section{Literature Cited}

Alford, R.A. and S. J. Richards. 1999. Global amphibian declines: A problem in applied ecology. Infectious diseases and amphibian declines. Annual Review of Ecology and Systematics. 30:133-165.

Alroy, J., 2015. Current extinction rates of reptiles and amphibians. Proceedings of the National Academy of Sciences. 112:13003-13008.

Araújo, M.B., Thuiller, W. and R. G. Pearson. 2006. Climate warming and the decline of amphibians and reptiles in Europe. Journal of Biogeography. 33:1712-172.

Bai, C., Garner, T.W. and Li, Y., 2010. First evidence of Batrachochytrium dendrobatidis in China: Discovery of chytridiomycosis in introduced American bullfrogs and native amphibians in the Yunnan Province, China. EcoHealth. 7:127-134.

Bai, C., Liu, X., Fisher, M.C., Garner, T.W. and Li, Y., 2012. Global and endemic Asian lineages of the emerging pathogenic fungus Batrachochytrium dendrobatidis widely infect amphibians in China. Diversity and Distributions. 18: 307-318.

Barinaga, M. 1990. Where have all the froggies gone? Science. 247:1033-34.

Barribeau, S.M., J. Villinger, and B. Waldman. 2008. Major histocompatibility complex based resistance to a common bacterial pathogen of amphibians. PLoS One. DOI:org/10.1371/journal.pone.0077528.

Bataille, A., Fong, J.J., Cha, M., Wogan, G.O., Baek, H.J., Lee, H., Min, M.S. and Waldman, B., 2013. Genetic evidence for a high diversity and wide distribution of endemic strains of the pathogenic chytrid fungus Batrachochytrium dendrobatidis in wild Asian amphibians. Molecular Ecology. 22:4196-4209. 
Bataille, A., Cashins, S.D., Grogan, L., Skerratt, L.F., Hunter, D., McFadden, M., Scheele, B., Brannelly, L.A., Macris, A., Harlow, P.S. and S. Bell. 2015. Susceptibility of amphibians to chytridiomycosis is associated with MHC class II conformation. Proceedings of the Royal Society of London (Biological Sciences). DOI:10.1098/rspb.2014.3127.

Bataille, A., Lee-Cruz, L., Tripathi, B., Kim, H., and B., Waldman. 2016. Microbiome Variation Across Amphibian Skin Regions: Implications for Chytridiomycosis Mitigation Efforts. Microbial ecology. 71:221-232.

Becker, C. G., D. Rodriguez, A. V. Longo, L. F. Toledo, C. Lambertini, D. S. Leite, C. F. B. Haddad, and K. R. Zamudio. 2015. Deforestation, host community structure, and amphibian disease risk. Basic and Applied Ecology.

DOI:10.1016/j.baae.2015.08.004.

Berger, L., Marantelli, G., Skerratt, L. F., and R. Speare. 2005. Virulence of the amphibian chytrid fungus Batrachochytrium dendrobatidis varies with the strain. Diseases of Aquatic Organisms. 68:47-50.

Berger, L., Roberts, A. A., Voyles, J., Longcore, J. E., Murray, K. A., and Skerratt, L. F. 2016. History and recent progress on chytridiomycosis in amphibians. Fungal Ecology. 19:89-99.

Berger, L. Speare, R. Daszak, P., Green, D. E, Cunningham, A. A., Goggin, C. L., Slocombe, R. Ragan, M. A. Hyatt, A.D., McDonald, K. R. Hines, H. B., Lips, K. R., Marantelli, G. and H. Parkes.1998. Chytridiomycosis causes amphibian mortality associated with population declines in the rainforests of Australia and Central America. Proceedings of the National Academy Sciences. 95:9031-9036.

Berger, L., Speare, R., and A. D. Hyatt. 1999b. Chytrid fungi and amphibian declines: overview, implications and future directions. In: Campbell A. (ed) Declines and disappearances of Australian frogs. Environment Australia. Canberra.

Berger, L., Speare, R. and A. Kent. 1999a. Diagnosis of chytridiomycosis in amphibians by histologic examination. Proceedings of Frog Symposium: Frogs in the Community, Queensland Museum. Brisbane.

Bielby, J., Cooper, N., Cunningham, A.A., Garner, T.W.J. and Purvis, A., 2008. Predicting susceptibility to future declines in the world's frogs. Conservation Letters. 1:82-90.

Blaustein, A. R., Wake, D. B., Sousa, W. P. 1994. Amphibian declines: Judging stability, persistence, and susceptibility of populations to local and global extinctions. Conservation Biology. 8:60-67.

Boyle, D. G., D. B. Boyle, V. Olsen, J. A. T. Morgan, and A. D. Hyatt. 2004. Rapid quantitative detection of chytridiomycosis (Batrachochytrium dendrobatidis) in amphibian samples using real-time Taqman PCR assay. Diseases of Aquatic Organisms. 60:141-148. 
Briggs, C. J., Knapp, R. A., and V. T. Vredenburg. 2010. Enzootic and epizootic of the chytrid fungal pathogen of amphibians. Proceeding of the National Academy of Sciences. 107:9695-9700.

Champion, S.H. and Seth, S.K., 1968. A revised survey of the forest types of India. A revised survey of the forest types of India. Manager of Publications, Delhi.

Chestnut, T. 2014. Emerging infectious disease in lentic environments: The ecology and biogeography of the amphibian chytrid fungus Batrachochytrium dendrobatidis, with perspectives on water quality, limnology, and chemical contaminants. Dissertation submitted to Oregon State University.

Collins, J. P. 2013. History, novelty, and emergence of an infectious amphibian disease. Proceedings of the National Academy of Sciences. 112:9193-9194.

Collins, J.P. and A. Storfer. 2003. Global amphibian declines: Sorting the hypotheses. Diversity and Distributions. 9:89-98.

Dahanukar, N., Krutha, K., Paingankar, M. S., Padhye, A. D., Modak, N., and S. Molur. 2013. Endemic Asian chytrid strain infection in threatened and endemic anurans of the northern Western Ghats, India. PloS One.

DOI:org/10.1371/journal.pone.0077528.

Daniels, R. J. R. 2003. Impact of tea cultivation on anurans in the Western Ghats. Current Science. 85:1415-1422.

Daskin, J. H., Alford, R. A. and R Puschendorf. 2011. Short-term exposure to warm microhabitats could explain amphibian persistence with Batrachochytrium dendrobatidis. PloS One. DOI:org/10.1371/journal.pone.0026215

Daszak, P., Berger, L., Cunningham, A.A., Hyatt, A.D., Green, D.E. and R. Speare. 1999 Emerging infectious diseases and amphibian population declines. Emerging Infectious Diseases. 5:735-748.

Erismis, U.C., Konuk, M., Yoldas, T., Agyar, P., Yumuk, D. and Korcan, S.E., 2014. Survey of Turkey's endemic amphibians for chytrid fungus Batrachochytrium dendrobatidis. Diseases of Aquatic Organisms. 111:153-157.

Farrer, R. A., Weinert, L. A., Bielby, J., Garner, T. W. J., Balloux, F., Clare, F., Bosch, J., Cunningham, A. A., Weldon, C., du Preez, L. H., Anderson, L., Pond, K. L. S., Shahar-Golan, R., Henk, A. D., and M. C. Fisher. 2011. Multiple emergences of genetically diverse amphibian-infecting chytrids include a globalized hypervirulent recombinant lineage. Proceedings of the National Academy of Sciences. 108:1-5.

Fernández-Beaskoetxea, S., Carrascal, L. M., Fernández-Loras, A., Fisher, M. C., and J, Bosch. 2015. Short Term Minimum Water Temperatures Determine Levels of Infection by the Amphibian Chytrid Fungus in Alytes obstetricans Tadpoles. PloS One. DOI:org/10.1371/journal.pone.0120237. 
Fong, J.J., Cheng, T.L., Bataille, A., Pessier, A.P., Waldman, B. and Vredenburg, V.T., 2015. Early 1900s detection of Batrachochytrium dendrobatidis in Korean amphibians. PloS One. DOI.org/10.1371/journal.pone.0115656.

Forrest, M.J., Edwards, M.S., Rivera, R., Sjoberg, J. and Jarger, J., 2015. High prevalence and seasonal persistence of amphibian chytrid fungus infections in the desertdwelling Amargosa Toad, Anaxyrus nelson. Herpetological Conservation and Biology. 10:917-925.

Frías-Alvarez, P., Vredenburg, V.T., Familiar-López, M., Longcore, J.E., GonzálezBernal, E., Santos-Barrera, G., Zambrano, L. and Parra-Olea, G., 2008. Chytridiomycosis survey in wild and captive Mexican amphibians. EcoHealth. 5:18-26.

George, R., Desai, I., and Suresh, B. 2008. Absence of chytridiomycosis in the skin of amphibians collected from Vadodara district of Gujarat. Journal of Cell and Tissue Research. 8:1565-1569.

Goka, K., Yokoyama, J., Une Y., Kuroki, T., Suzuki, K., Nakahara, M., Kobayashi, A., Inaba, S., Mizutani, T., and Hyatt, A. D,. 2009. Amphibian chytridiomycosis in Japan: Distribution, haplotypes and possible route of entry into Japan. Molecular Ecology. 18:4757-4774.

Gower, D.J., Doherty-Bone, T., Loader, S.P., Wilkinson, M., Kouete, M.T., Tapley, B., Orton, F., Daniel, O.Z., Wynne, F., Flach, E. and Müller, H., 2013.

Batrachochytrium dendrobatidis infection and lethal chytridiomycosis in caecilian amphibians (Gymnophiona). EcoHealth. 10:173-183.

Harris, R. N., James, T. Y., Lauer, A., Simon, M. A., and A., Patel. 2006. Amphibian pathogen Batrachochytrium dendrobatidis is inhibited by the cutaneous bacteria of amphibian species. EcoHealth. 3:53-56.

Harris, R. N., Brucker, R. M., Walke, J. B., Becker, M. H., Schwantes, C. R., Flaherty, D. C., B. A. Lam, D. C. Woodhams, C. J. Briggs, V. T. Vredenburg and Minbiole, K. P. 2009. Skin microbes on frogs prevent morbidity and mortality caused by a lethal skin fungus. The ISME journal. 3:818-824.

IUCN 2016. The IUCN Red List of Threatened Species. Version 2016-2. $<$ http://www.iucnredlist.org $>$. Downloaded on 04 September 2016.

James, T.Y., Toledo, L.F., Rödder, D., Silva Leite, D., Belasen, A.M., BetancourtRomán, C.M., Jenkinson, T.S., Soto-Azat, C., Lambertini, C., Longo, A.V. and Ruggeri, J., 2015. Disentangling host, pathogen, and environmental determinants of a recently emerged wildlife disease: Lessons from the first 15 years of amphibian chytridiomycosis research. Ecology and Evolution. 5:4079-4097.

Johnson, M. L., and Speare, R. 2003. Survival of Batrachochytrium dendrobatidis in water: quarantine and disease control implications. Emerging Infectious Diseases. 9:922-925. 
Johnson, M.L., Berger, L., Philips, L., Speare, R., 2003. Fungicidal effects of chemical disinfectants, UV light, desiccation and heat on the amphibian chytrid Batrachochytrium dendrobatidis. Diseases of Aquatic Organisms. 57:255-260.

Kadekaru, S., Tamukai, K.I., Tominaga, A., Goka, K. and Une, Y., 2015. Spontaneous oral chytridiomycosis in wild bullfrog tadpoles in Japan. Journal of Veterinary Medical Science. 78:573-577.

Kaiser, K. and Grafe, T.U., 2011. Chytrid fungus not found in preliminary survey of lowland amphibian populations across northwestern Borneo. Herpetological Review. 42:59.

Kolby, J.E., Smith, K.M., Berger, L., Karesh, W.B., Preston, A., Pessier, A.P. and Skerratt, L.F., 2014. First evidence of amphibian chytrid fungus (Batrachochytrium dendrobatidis) and ranavirus in Hong Kong amphibian trade. PLoS One. DOI:org/10.1371/journal.pone.0090750.

Kolby, J. E., Ramirez, S. D., Berger, L., Griffin, D. W., Jocque, M., and L. F. Skerratt. 2015a. Presence of amphibian chytrid fungus (Batrachochytrium dendrobatidis) in rainwater suggests aerial dispersal is possible. Aerobiologia. 31:411-419.

Kolby, J. E., Ramirez, S. D., Berger, L., Richards-Hrdlicka, K. L., Jocque, M., and L. F. Skerratt. 2015b. Terrestrial dispersal and potential environmental transmission of the amphibian chytrid fungus (Batrachochytrium dendrobatidis). PloS One. DOI:org/10.1371/journal.pone.0125386.

Kriger, K.M., Hero, J.M. and Ashton, K.J., 2006a. Cost efficiency in the detection of chytridiomycosis using PCR assay. Diseases of Aquatic Organisms. 71:149-154.

Kriger, K. M., Hines, H. B., Hero, J. M., Hyatt, A. D., and D. G. Boyle. $2006 b$. Techniques for detecting chytridiomycosis in wild frogs: Comparing histology with real-time Taqman PCR. Diseases of Aquatic Organisms. 71:141-14.

Kusrini, M.D., Skerratt, L.F., Garland, S., Berger, L. and Endarwin, W., 2008. Chytridiomycosis in frogs of Mount Gede-Pangrango, Indonesia. Diseases of Aquatic Organisms. 82:187-194.

Labisko, J., Maddock, S. T., Taylor, M. L., Chong-Seng, L., Gower, D. J., Wynne, F. J., Wombwell, E., Morel, C., French, G., C., Bunbury, N., and K. Bradfield. 2015. Chytrid fungus (Batrachochytrium dendrobatidis) undetected in the two orders of Seychelles amphibians. Herpetological Review. 46:41-45.

Laurance, W. F., McDonald, K. R. and R. Speare.1996. Epidemic disease and the catastrophic decline of Australian rainforest frogs. Conservation Biology. 77:203212. 
Lips, K.R. 1998. Decline of a tropical montane amphibian fauna. Conservation Biology. 12:106-117.

Lips, K.R. 1999. Mass mortality and population declines of anurans at an upland site in western Panama. Conservation Biology. 13:117-125.

Lips, K.R., Bren, F., Brem, R., Reeve, J.D., Alford, R.A., Voyles, J., Careys, C., Livo, A., Pessier, A.P. and J. P. Collins. 2006. Emerging infectious disease and the loss of biodiversity in a Neotropical amphibian community. Proceeding of the National Academy of Sciences. 103:3165-3170.

Lips, K.R., Diffendorfer, J., Mendelson, J.R. III and M. W. Sears. 2008. Riding the wave: reconciling the roles of disease and climate change in amphibian declines. PLoS Biology. 6:441-454.

Lips, K.R. and Donnelly, M.A., 2005. What the tropics can tell us about declining amphibian populations: current patterns and future prospects. In: Lannoo, M. J., editor. North American amphibians: status and conservation. Chicago. University of Chicago Press.

Longcore, J.E., Pessier, A.P., Nichols, D.K.. 1999. Batrachochytrium dendrobatidis gen. et sp. nov., a chytrid pathogenic to amphibians. Mycologia. 91:219-227.

Longcore, J. E., Letcher, P. M., and T., Y., James. 2012. Homolaphlyctis polyrhiza gen. et sp. nov., a species in the Rhizophydiales (Chytridiomycetes) with multiple rhizoidal axes. Mycotaxon. 118:433-440.

Lötters, S., Kielgast, J., Bielby, J., Schmidtlein, S., Bosch, J., Veith, M., Walker, S.F., Fisher, M.C. and Rödder, D., 2009. The link between rapid enigmatic amphibian decline and the globally emerging chytrid fungus. EcoHealth. 6:358-372.

Lubick, N. 2015. Wild toads saved from killer fungal disease. Scientific American. http://www.scientificamerican.com/article/wild-toads-saved-from-killer-fungaldisease/

Martel, A., Adriaensen, C., Bogaerts, S., Ducatelle, R., Favoreel, H., Crameri, S., Hyatt, A.D., Haesebrouck, F. and Pasmans, F., 2012. Novel Chlamydiaceae disease in captive salamanders. Emerging Infectious Diseases. 18:1020-1022.

Martel, A., Spitzen-van der Sluijs, A., Blooi, M., Bert, W., Ducatelle, R., Fisher, M.C., Woeltjes, A., Bosman, W., Chiers, K., Bossuyt, F. and F., Pasmans. 2013.

Batrachochytrium salamandrivorans sp. nov. causes lethal chytridiomycosis in amphibians. Proceedings of the National Academy of Sciences. 110:1532515329 .

Mazzoni, R., Cunningham, A.A., Daszak, P., Apolo, A., Perdomo, E. and Speranza, G., 2003. Emerging pathogen of wild amphibians in frogs (Rana catesbeiana) farmed for international trade. Emerging Infectious Diseases. 9:995-998. 
McCallum, M., L. 2007. Amphibian decline or extinction? Current declines dwarf background extinction rate. Journal of Herpetology. 41:483-491.

McDiarmid, R.W. and Altig, R., 1999. Tadpoles: The biology of anuran larvae. University of Chicago Press.

McMahon, T.A., Brannelly, L.A., Chatfield, M.W., Johnson, P.T., Joseph, M.B., McKenzie, V.J., Richards-Zawacki, C.L., Venesky, M.D. and J., R., Rohr. 2013. Chytrid fungus Batrachochytrium dendrobatidis has non-amphibian hosts and releases chemicals that cause pathology in the absence of infection. Proceedings of the National Academy of Sciences. 110:210-215.

McMahon, T. A., Sears, B. F., Venesky, M. D., Bessler, S. M., Brown, J. M., Deutsch, K., Halstead, N. T., Lentz, G., Tenouri, N., Young, S. and D. J., Civitello, 2014. Amphibians acquire resistance to live and dead fungus overcoming fungal immunosuppression. Nature. 511:224-227.

Melzer, S. and Bishop, P.J., 2010. Skin peptide defenses of New Zealand frogs against chytridiomycosis. Animal Conservation. 13:44-52.

Mendelson, J. R. III. 2011. Shifted Baselines, Forensic Taxonomy, and Rabbs' Fringelimbed Treefrog: The Changing Role of Biologists in an Era of Amphibian Declines and Extinctions. Herpetological Review. 42:21-25.

Monastersky, R. 2014. Biodiversity: Life--a status report. Nature. 516:158-161.

Molur, S., Krutha, K., Paingankar, M. S., and Dahanukar, N. 2015. Asian strain of Batrachochytrium dendrobatidis is widespread in the Western Ghats, India. Diseases of aquatic organisms. 112:251-255.

Nair, A., Daniel, O., Gopalan, S.V., George, S., Kumar, K.S., Merilä, J. and Teacher, A.G.F. 2011. Infectious disease screening of Indirana frogs from the Western Ghats biodiversity hotspot. Herpetological Review. 42:554-557.

Nowakowski, A.J., Whitfield, S.M., Eskew, E.A., Thompson, M.E., Rose, J.P., Caraballo, B.L., Kerby, J.L., Donnelly, M.A. and Todd, B.D., 2016. Infection risk decreases with increasing mismatch in host and pathogen environmental tolerances. Ecology Letters. 19:1051-1061.

Olson, D. H., D. M. Aanensen, K. L. Ronnenberg, C. I. Powell, S. F. Walker, J. Bielby, T. W. J. Garner, G. Weaver, and M. C. Fisher. 2013. Mapping the global emergence of Batrachochytrium dendrobatidis, the amphibian chytrid fungus. PloS One. DOI:org/10.1371/journal.pone.0056802.

Parker, J.M., Mikaelian, I., Hahn, N. and Diggs, H.E., 2002. Clinical diagnosis and treatment of epidermal chytridiomycosis in African clawed frogs (Xenopus tropicalis). Comparative Medicine. 52:265-268. 
Pechmann, J. H. K., Scott, D. E., Semlitsch, R. E., Caldwell, J. P., Vitt, L. J., and J. W. Gibbons. 1991. Declining amphibian populations: The problem of separating human impacts from natural fluctuations. Science. 253:892-9.

Phillips, B. L., and Puschendorf, R. 2013. Do pathogens become more virulent as they spread? Evidence from the amphibian declines in Central America. Proceedings of the Royal Society of London (Biological Sciences). DOI:org/10.1098/rspb.2013.1290

Piotrowski, J. S., Annis, S. L., and Longcore, J. E. 2004. Physiology of Batrachochytrium dendrobatidis, a chytrid pathogen of amphibians. Mycologia. 96:9-15.

Pounds, J. Alan, Martín R. Bustamante, Luis A. Coloma, Jamie A. Consuegra, Michael PL Fogden, Pru N. Foster, Enrique La Marca Karen L. Masters' Andrés MerinoViteri' Robert Puschendorf' Santiago R. Ron' G. Arturo Sánchez-Azofeifa, Christopher J. Still' and Bruce E. Young. 2006. Widespread amphibian extinctions from epidemic disease driven by global warming. Nature. 439:161-6.

Puschendorf, R., Hoskin, C.J., Cashins, S.D., McDonald, K., Skerratt, L.F., Vanderwal, J. and Alford, R.A., 2011. Environmental refuge from disease-driven amphibian extinction. Conservation Biology. 25:956-964.

Rachowicz, L. J., and Vredenburg, V. T. 2004. Transmission of Batrachochytrium dendrobatidis within and between amphibian life stages. Diseases of Aquatic Organisms. 61:75-83.

Rebollar, E. A., Hughey, M. C., Medina, D., Harris, R. N., Ibáñez, R., and Belden, L. K. (2016). Skin bacterial diversity of Panamanian frogs is associated with host susceptibility and presence of Batrachochytrium dendrobatidis. The International Society for Microbial Ecology. 10:1682-1695.

Richmond, J.Q., Savage, A.E., Zamudio, K.R. and Rosenblum, E.B., 2009. Toward immunogenetic studies of amphibian chytridiomycosis: Linking innate and acquired immunity. Bioscience. 59:311-320.

Rohr, J. R. and T. R. Raffel. 2010. Linking global climate and temperature variability to widespread amphibian declines putatively caused by disease. Proceedings of the National Academy of Sciences of the United States of America. 107:8269-8274.

Rollins-Smith, L.A. and Conlon, J.M., 2005. Antimicrobial peptide defenses against chytridiomycosis, an emerging infectious disease of amphibian populations. Developmental \& Comparative Immunology. 29:589-598.

Rosenblum, E.B., J. Stajich, N. Maddox, and M.B. Eisen. 2008. Global gene expression profiles of life stages of the deadly amphibian pathogen Batrachochytrium dendrobatidis. Proceedings of the National Academy of Sciences. 105:1703417039 .

Rowley, J.J. and Alford, R.A., 2013. Hot bodies protect amphibians against chytrid infection in nature. Scientific reports, 3. 
Savage, A. E., and Zamudio, K. R. 2011. MHC genotypes associate with resistance to a frog-killing fungus. Proceedings of the National Academy of Sciences. 108:16705-16710.

Savage, A., E., Grismer, L.L., Anuar, S., Onn, C.K., Grismer, J.L., Quah, E., Muin, M.A., Ahmad, N., Lenker, M. and Zamudio, K.R., 2011. First record of Batrachochytrium dendrobatidis infecting four frog families from Peninsular Malaysia. EcoHealth. 8:121-128.

Savage, A. E., Terrell, K.A., Gratwicke, B., Mattheus, N.M., Augustine, L. and Fleischer, R.C., 2016. Reduced immune function predicts disease susceptibility in frogs infected with a deadly fungal pathogen. Conservation Physiology. DOI:10.1093/conphys/cow011.

Scheele, B.C., Guarino, F., Osborne, W., Hunter, D.A., Skerratt, L.F. and Driscoll, D.A., 2014a. Decline and re-expansion of an amphibian with high prevalence of chytrid fungus. Biological Conservation. 170:86-91.

Scheele, B.C., Hunter, D.A., Grogan, L.F., Berger, L.E.E., Kolby, J.E., McFadden, M.S., Marantelli, G., Skerratt, L.F. and Driscoll, D.A., 2014b. Interventions for reducing extinction risk in chytridiomycosis-threatened amphibians. Conservation biology. 28:1195-1205.

Skerratt, L.F., Berger, L., Speare, R., Cashins, S., McDonald, K.R., Phillott, A.D., Hines, H.B. and N., Kenyon. 2007. Spread of chytridiomycosis has caused the rapid global decline and extinction of frogs. EcoHealth. 4:125-134.

Sodhi, N. S., Bickford, D., Diesmos, A. C., Lee, T. M., Koh, L. P., Brook, B.W., Sekercioglu, C. H., and C. J. A. Bradshaw. 2008. Measuring the meltdown: Driver of global amphibian extinction and decline. PLoS One. DOI:org/10.1371/journal.pone.0001636.

Soorae, P.S., Abdessalaam, T.A., Tourenq, C., Shuriqi, M.K. and Mehairbi, M.A., 2012. Preliminary analyses suggest absence of the amphibian chytrid fungus in native and exotic amphibians of the United Arab Emirates. Salamandra. 48:173-176.

Speare, R., Skerratt, L., Berger, L., Hines, H., Hyatt, A., Mendez, D., McDonald, K., Hero, J.M., Marantelli, G., Muller, R. and Alford, R., 2005. A project that designs and trials a pilot survey to map the distribution of chytridomycosis (caused by the amphibian chytrid fungus) in Australian frogs. Project ID: 44381.

Stevenson, L.A., Alford, R.A., Bell, S.C., Roznik, E.A., Berger, L. and Pike, D.A., 2013. Variation in thermal performance of a widespread pathogen, the amphibian chytrid fungus Batrachochytrium dendrobatidis. PloS One.

DOI:org/10.1371/journal.pone.0073830.

Stuart, S. N., Chanson, J. S., Cox, N. A., Young, B. E., Rodrigues, A. S. L., Fischman, D. L., and R. W. Waller. 2004. Status and trends of amphibian declines and extinctions worldwide. Science. 306:1783-1786. 
Swei, A., Rowley, J.J., Rödder, D., Diesmos, M.L., Diesmos, A.C., Briggs, C.J., Brown, R., Cao, T.T., Cheng, T.L., Chong, R.A. and Han, B., 2011. Is chytridiomycosis an emerging infectious disease in Asia? PLoS One.

DOI:org/10.1371/journal.pone.0023179.

Tarrant, J., Cilliers, D., du Preez, L. H., and C., Weldon. 2013. Spatial assessment of amphibian chytrid fungus (Batrachochytrium dendrobatidis) in South Africa confirms endemic and widespread infection. PloS One.

DOI:org/10.1371/journal.pone.0069591.

Thien, T.N., Martel, A., Brutyn, M., Bogaerts, S., Sparreboom, M., Haesebrouck, F., Fisher, M.C., Beukema, W., Van, T.D., Chiers, K. and Pasmans, F., 2013. A survey for Batrachochytrium dendrobatidis in endangered and highly susceptible Vietnamese salamanders (Tylototriton spp.). Journal of Zoo and Wildlife Medicine. 44:627-633.

Une, Y., Kadekaru, S., Tamukai, K., Goka, K. and Kuroki, T., 2008. First report of spontaneous chytridiomycosis in frogs in Asia. Diseases of Aquatic Organisms. 82:157-160.

Venesky, M.D., Raffel, T.R., McMahon, T.A. and Rohr, J.R., 2014. Confronting inconsistencies in the amphibian-chytridiomycosis system: Implications for disease management. Biological Reviews. 89:477-483.

Vörös, J., Satasook, C., Bates, P. and Wangkulangkul, S., 2012. First record of the amphibian chytrid fungus, Batrachochytrium dendrobatidis in Thailand. Herpetol Notes. 5: 519-521.

Voyles, J., Johnson, L.R., Briggs, C.J., Cashins, S.D., Alford, R.A., Berger, L., Skerratt, L.F., Speare, R. and E., B., Rosenblum. 2014. Experimental evolution alters the rate and temporal pattern of population growth in Batrachochytrium dendrobatidis, a lethal fungal pathogen of amphibians. Ecology and Evolution. 4:3633-3641.

Wake, D. B., and Vredenburg, V. T. (2008). Are we in the midst of the sixth mass extinction? A view from the world of amphibians. Proceedings of the National Academy of Sciences. 105:11466-11473.

Warne, R. W., LaBumbard, B., LaGrange, S., Vredenburg, V. T., and A, Catenazzi. 2016. Co-infection by chytrid fungus and ranaviruses in wild and harvested frogs in the tropical Andes. PloS One. DOI:org/10.1371/journal.pone.0145864.

Wei, Y., Xu, K., Zhu, D.Z., Chen, X.F. and Wang, X.L., 2010. Early-spring survey for Batrachochytrium dendrobatidis in wild Rana dybowskii in Heilongjiang Province, China. Diseases of Aquatic Organisms. 92:241-244.

Weldon, C., Du Preez, L. H., Hyatt, A. D., Muller, R., and Speare, R. 2004. Origin of the amphibian chytrid fungus. Emerging Infectious Diseases. 10:2100-2105. 
Whitfield, S. M., Bell, K. E., Philippi, T., Sasa, M., Bolaños, Chaves, F. G., Savage, J. M., and M. A. Donnelly. 2007. Amphibian and reptile declines over 35 years at La Selva, Costa Rica. Proceedings of the National Academy of Sciences. 104: $8352-835$.

Whitfield, Steven M., Enigmatic Faunal Declines at La Selva, Costa Rica: Patterns and Processes in a Collapsing Neotropical Herpetofauna. 2011. FIU Electronic Theses and Dissertations. Paper 435.

Whitfield, S. M., Kerby, J., Gentry, L. R., and Donnelly, M. A. 2012. Temporal variation in infection prevalence by the amphibian chytrid fungus in three species of frogs at La Selva, Costa Rica. Biotropica. 44:779-784.

Whitfield, S.M., Geerdes, E., Chacon, I., Ballestero Rodriguez, E., Jimenez, R.R., Donnelly, M.A. and Kerby, J.L. 2013. Infection and co-infection by the amphibian chytrid fungus and ranavirus in wild Costa Rican frogs. Diseases in Aquatic Organisms. 104:173-178.

Whitfield, S.M., Lips, K.R. and Donnelly, M.A., 2016. Amphibian Decline and Conservation in Central America. Copeia. 104:351-379.

Woodhams, D. C., Alford, R. A., and Marantelli, G. 2003. Emerging disease of amphibians cured by elevated body temperature. Diseases of Aquatic Organisms. 55:65-67.

Woodhams, D.C., Rollins-Smith, L.A., Carey, C., Reinert, L., Tyler, M.J. and Alford, R. A. 2006. Population trends associated with skin peptide defenses against chytridiomycosis in Australian frogs. Oecologia. 146:531-540.

Woodhams, D. C., Ardipradja, K., Alford, R. A., Marantelli, G., Reinert, L. K., and Rollins-L., A., Smith. 2007. Resistance to chytridiomycosis varies among amphibian species and is correlated with skin peptide defenses. Animal Conservation. 10:409-417.

Yang, H., Baek, H., Speare, R., Webb, R., Park, S., Kim, T., Lasater, K.C., Shin, S., Son, S., Park, J. and Min, M., 2009. First detection of the amphibian chytrid fungus Batrachochytrium dendrobatidis in free-ranging populations of amphibians on mainland Asia: Survey in South Korea. Diseases of Aquatic Organisms. 86:9-13.

Yumi, U., Koichi, G. and Hidetoshi, O., 2010. Origin of the world frog pandemic: Evidence from East Asia supports the novel pathogen theory. Journal of Comparative Pathology, 143:324.

Zhu, W., Bai, C., Wang, S., Soto-Azat, C., Li, X., Liu, X. and Li, Y., 2014. Retrospective survey of museum specimens reveals historically widespread presence of Batrachochytrium dendrobatidis in China. EcoHealth. 11:241-250.

Zhu, W., Fan, L., Soto-Azat, C., Yan, S., Gao, X., Liu, X., Wang, S., Liu, C., Yang, X. and Li, Y., 2016. Filling a gap in the distribution of Batrachochytrium 
dendrobatidis: Evidence in amphibians from northern China. Diseases of Aquatic Organisms. 118:259-265. 


\section{Tables}

\begin{tabular}{ll}
\hline $0.1 \mathrm{M}$ Tris-Cl $(\mathrm{pH} 8.0)$ & $1 \mathrm{ml}$ \\
$0.5 \mathrm{M}$ EDTA $(\mathrm{pH} 8.0)$ & $2 \mathrm{ml}$ \\
Non-idet P-40 & $50 \mathrm{uL}$ \\
$1 \mathrm{M} \mathrm{NaCl}$ & $100 \mathrm{uL}$ \\
Mili Q water & $6.85 \mathrm{~m}$ \\
------------------------
\end{tabular}

Table. 4.1. Composition of Extraction buffer. 


\begin{tabular}{|c|c|}
\hline Master mix & $5 \mathrm{ul}$ \\
\hline Forward primer (10 pmole/ul) & $0.5 \mathrm{ul}$ \\
\hline Reverse primer $(10 \mathrm{pmole} / \mathrm{ul})$ & $0.5 \mathrm{ul}$ \\
\hline Mili Q water/ nuclease free $\mathrm{H} 2 \mathrm{O}$ & $3 \mathrm{ul}$ \\
\hline DNA & $1 \mathrm{ul}$ \\
\hline Total & 10ul \\
\hline
\end{tabular}

Table. 4.2. Composition of PCR mix 


\begin{tabular}{c|ccccc} 
Sn/Year & Species Name & Tea & Shola & Eucalyptus & Other \\
\hline 1 & Duttaphrynus melanostictus & Yes & No & Yes & road \\
2 & Duttaphrynus paritelis & No & No & Yes & $\begin{array}{c}\text { Roadside, } \\
\text { Village } \\
\text { housing }\end{array}$ \\
& Fejervarya brevipalmata & & & & Swamp \\
3 & Fejervarya sps & No & No & No & Swamp \\
4 & Ghatixalus asterops & No & No & Yes & Stream \\
5 & Yes & No & No & vegetation \\
& Indirana sps & No & Yes & No & Stream \\
6 & Micrixalus adonis & No & Yes & No & Steam \\
7 & Micrixalus fuscus & No & Yes & No & Steam \\
8 & Nyctibatrachus poocha & Yes & No & No & Steam \\
9 & Ramanella cf montana & Yes & Yes & No & - \\
10 & Raorchestes dubois & Yes & Yes & Yes & - \\
11 & Raorchestes beddomii & Yes & Yes & Yes & - \\
12 & Raorchestes chlorosomma & Yes & Yes & No & - \\
13 & Raorchestes griet & Yes & Yes & No & Roadside \\
14 & Rarochestes jayarami & Yes & No & No & Roadside \\
15 & Raorchestes munnarensis & Yes & Yes & No & Roadside \\
16 & Rhacophorus pseudomalabaricus & No & Yes & No & Stream \\
17 & & & & & vegetation
\end{tabular}

Table. 4.3. Habitats where frogs were swabbed during the years 2012-2015 in Munnar, Kerala 


\begin{tabular}{c|cccccc} 
Sn/Year & Species Name & 2012 & 2013 & 2014 & 2015 & Total \\
\hline 1 & Duttaphrynus melanostictus & 0 & 4 & 0 & 0 & 4 \\
2 & Duttaphrynus paritelis & 0 & 1 & 0 & 0 & 1 \\
3 & Fejervarya brevipalmata & 1 & 0 & 0 & 0 & 1 \\
4 & Fejervarya sps & 0 & 8 & 10 & 4 & 22 \\
5 & Ghatixalus asterops & 7 & 3 & 10 & 11 & 31 \\
6 & Indirana sps & 0 & 1 & 2 & 1 & 4 \\
7 & Micrixalus adonis & 0 & 0 & 0 & 3 & 3 \\
8 & Micrixalus fuscus & 3 & 7 & 3 & 0 & 13 \\
9 & Nyctibatrachus poocha & 1 & 4 & 4 & 9 & 18 \\
10 & Ramanella cf montana & 0 & 5 & 0 & 0 & 5 \\
11 & Raorchestes dubois & 0 & 5 & 4 & 2 & 11 \\
12 & Raorchestes beddomii & 3 & 1 & 3 & 18 & 25 \\
13 & Raorchestes chlorosomma & 9 & 5 & 0 & 1 & 15 \\
14 & Raorchestes griet & 0 & 0 & 3 & 0 & 3 \\
15 & Rarochestes jayarami & 0 & 17 & 12 & 0 & 29 \\
16 & Raorchestes munnarensis & 6 & 5 & 8 & 9 & 28 \\
17 & Rhacophorus pseudomalabaricus & 0 & 0 & 3 & 0 & 3 \\
Total & & 30 & 66 & 62 & 58 & 216
\end{tabular}

Table. 4.4. List and number of species swabbed during the years 2012-2015 in Munnar, Kerala. 


\begin{tabular}{c|cc}
\multicolumn{1}{c|}{ SN/YEAR } & SPECIES NAME & IUCN RED LIST STATUS \\
\hline 1 & Raorchestes chlorosomma & Critically Endangered \\
2 & Raorchestes griet & Critically Endangered \\
3 & Rhacophorus pseudomalabaricus & Critically Endangered \\
4 & Raorchestes munnarensis & Critically Endangered \\
5 & Fejervarya brevipalmata & Data Deficient \\
6 & Fejervarya spp & Data Deficient \\
7 & Ghatixalus asterops & Data Deficient \\
8 & Indirana spp & Data Deficient \\
9 & Duttaphrynus melanostictus & Least Concern \\
10 & Duttaphrynus paritelis & Near Threatened \\
11 & Micrixalus fuscus & Near Threatened \\
12 & Raorchestes beddomii & Near Threatened \\
13 & Micrixalus adonis & Not Evaluated \\
14 & Nyctibatrachus poocha & Not Evaluated \\
15 & Ramanella cf montana & Not Evaluated \\
16 & Rarochestes jayarami & Not Evaluated \\
17 & Raorchestes dubois & Vulnerable \\
& &
\end{tabular}

Table. 4.5. IUCN Red List categories all the species tested for Bd between 2012-2015 (IUCN Red List, 2015). 


\section{Figures}
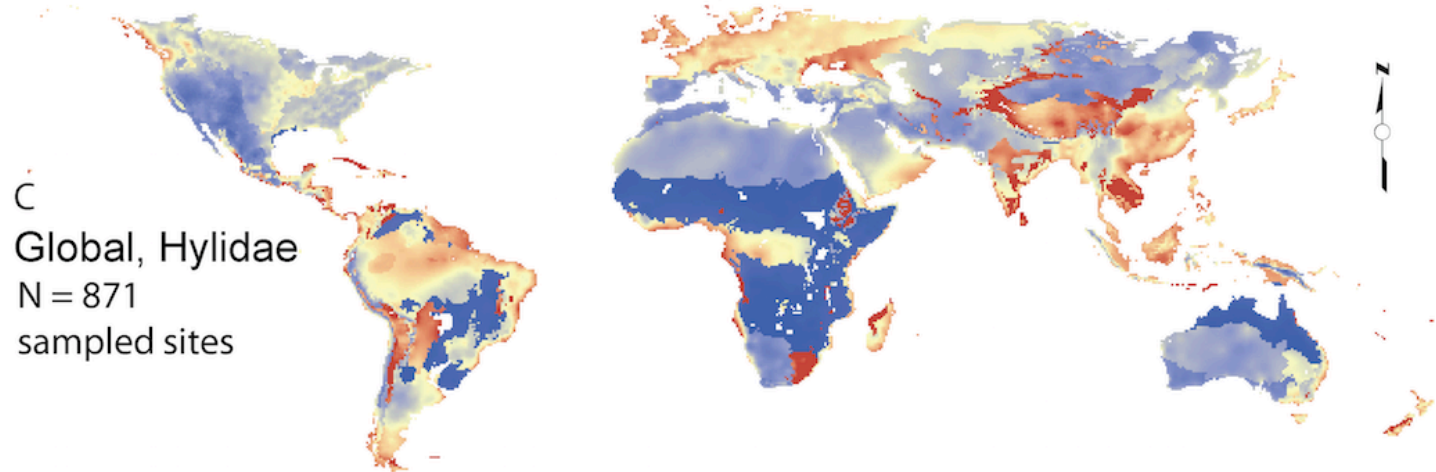

$$
\begin{array}{lll}
0 & 4,000 \quad 8,000 \\
\hline
\end{array} \quad \text { Kilometers }
$$

Figure 4.1. Probablity of chytrid infection for Hylid amphibians globally from extrapolated maps (Olsen et al. 2013) 


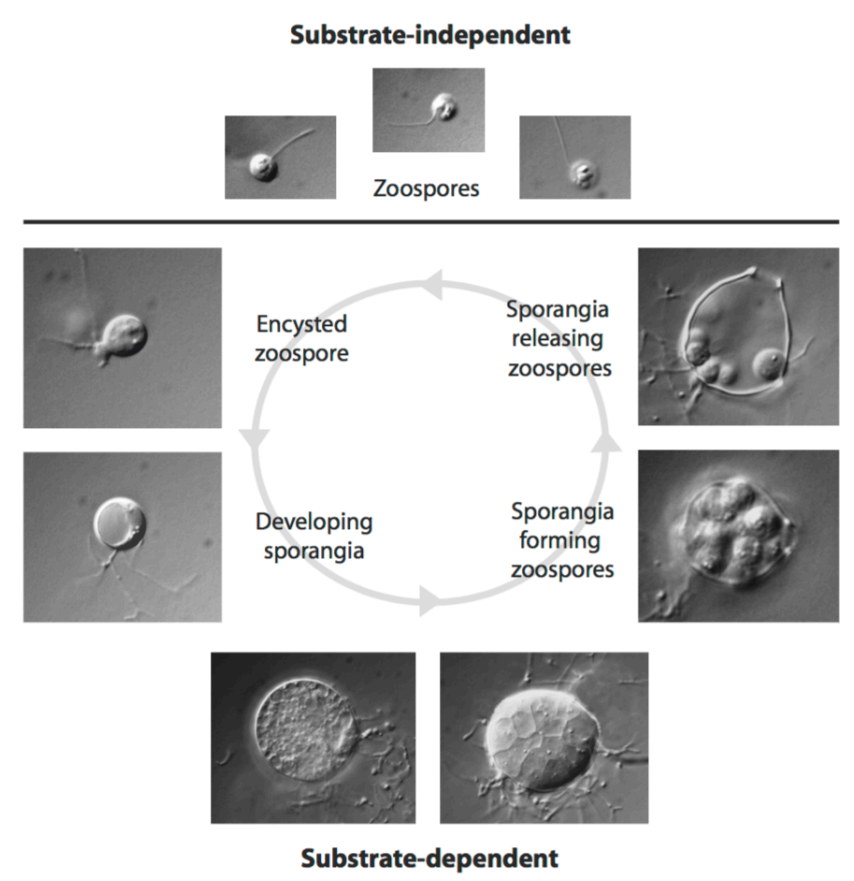

Figure 4.2. Life-cycle of Chytrid showing both aquatic (substrate independent) and terrestrial phases (substrate dependent) (Rosenblum et al. 2008). 


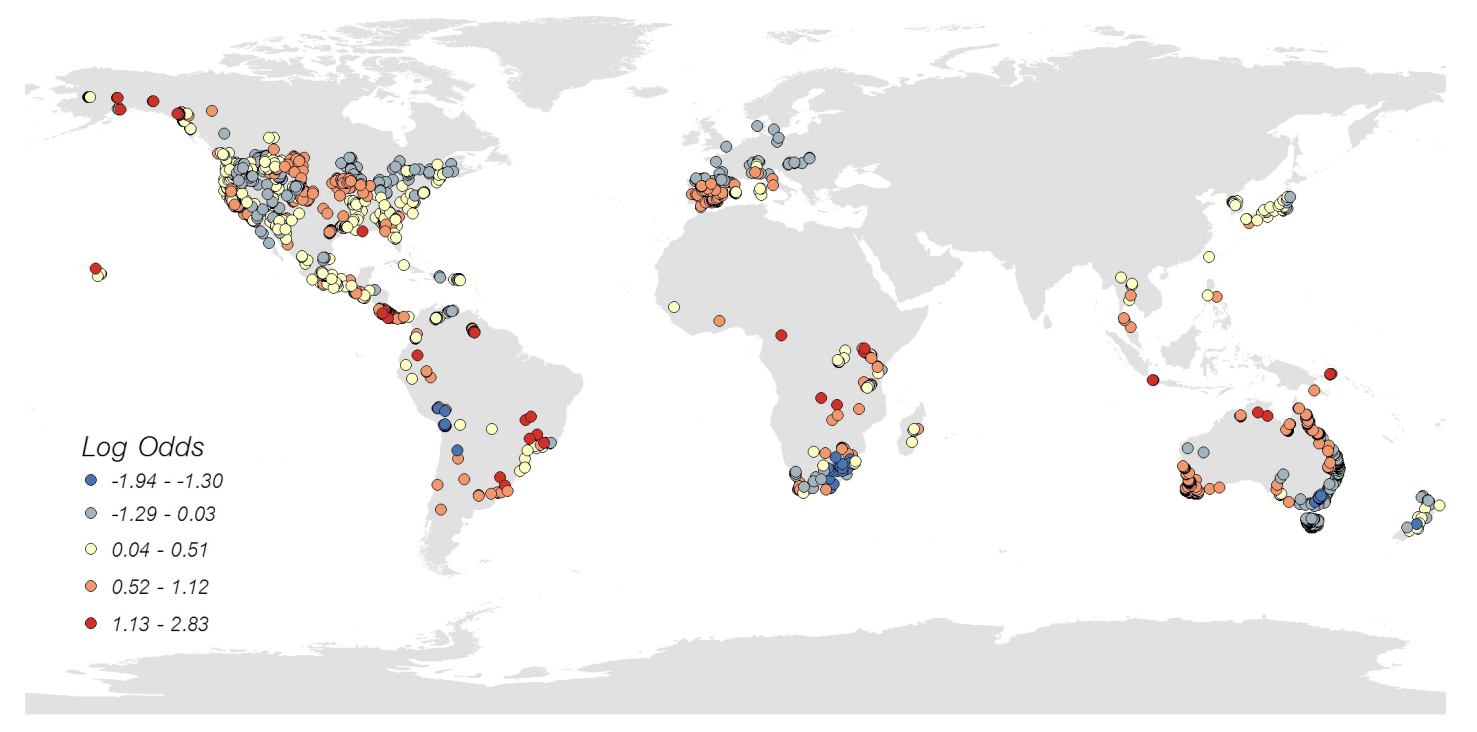

Figure 4.3. Global odds of chytrid detection in amphibians (Olsen et al. 2013). 


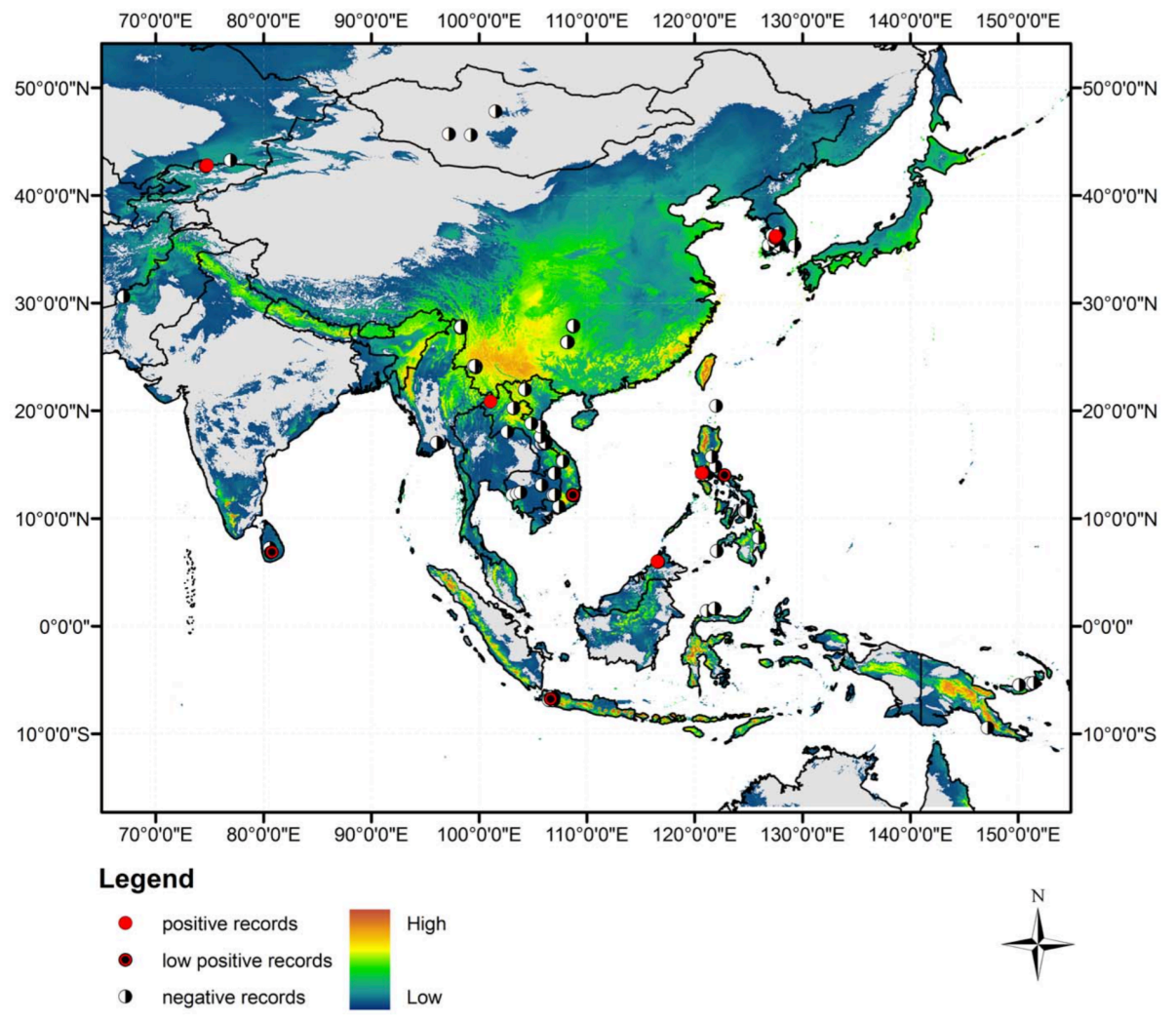

Figure 4.4. Map of predicted and observed Batrachytrium dendrobatidis detection in Asian amphibians (Swei et al. 2011). 


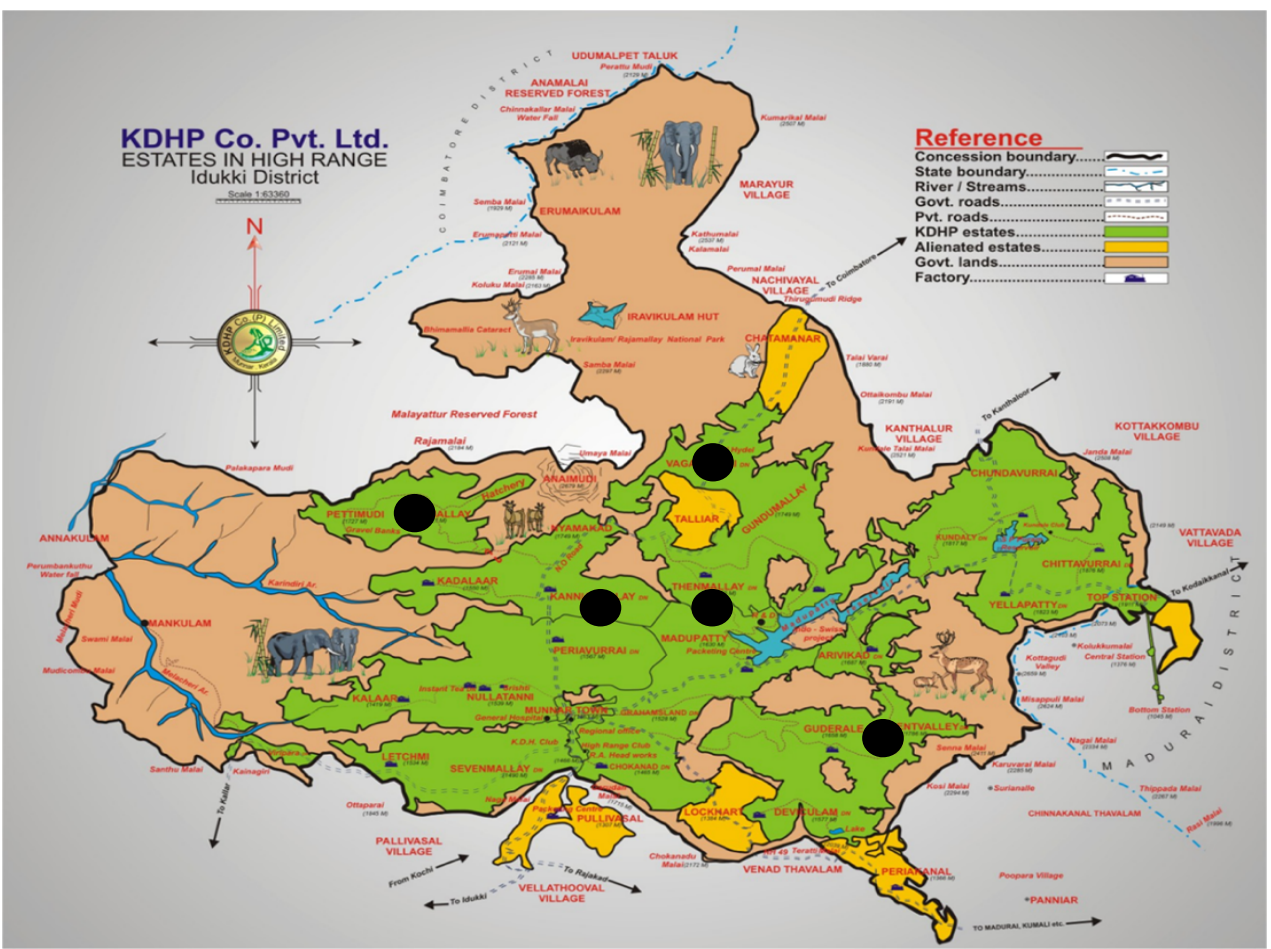

Figure 4.5. Map of KDHP Co Lt. Black dots mark estates were samping was done (Kanniamallay, SilentValley, Madupatty, Rajamallay, and Vagavurrai) (Kanan Devan Hills Private Cooperation Limited). 
Average Rainfall+SD(mm) and Relative humidity+SD(\%) for Rajamala in 2012

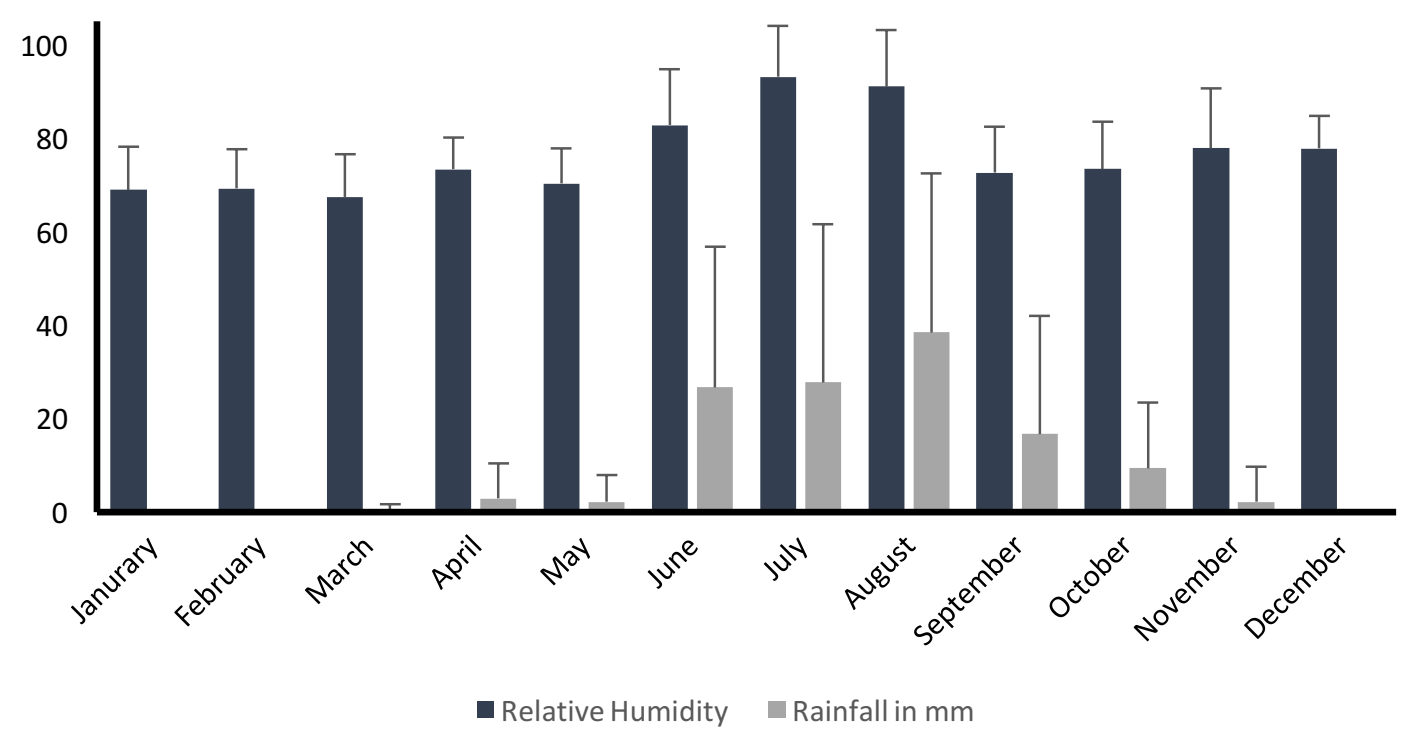

Figure 4.6. Monthly averages of Rainfall and humidity for year 2012 in Rajamala tea estate, Munnar, India. 


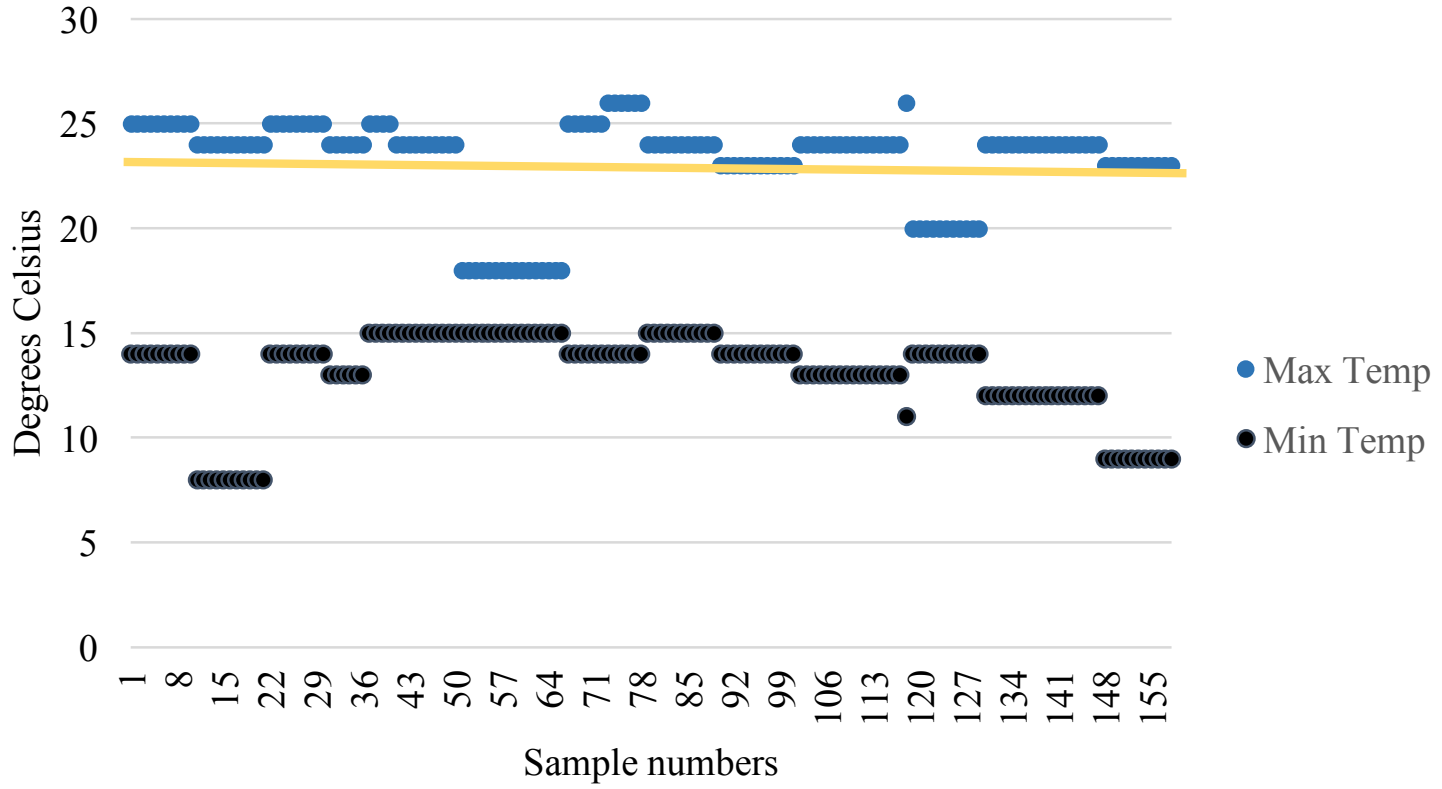

Figure 4.7. Maximum and minimum temperatures on days when samples were collected along with a line to represent the highest temperature that Bd spores can withstand. 


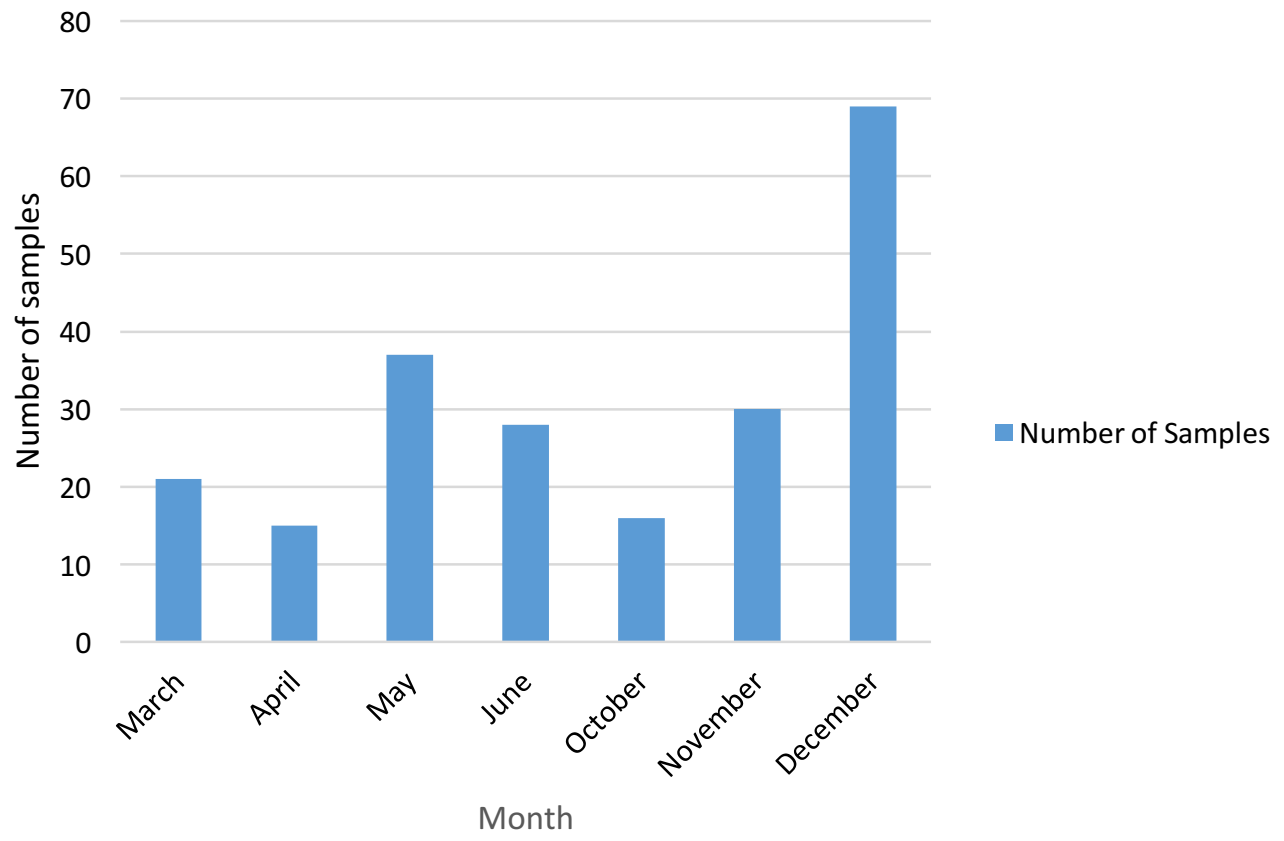

Figure 4.8. Number of swabs collected per month between 2012 and 2015. 


\section{CONCLUSION}

The tea plantation landscape in south India is dominated by tea fields, eucalyptus patches, and small remnant patches of shola forests. My goal was to test determine if there was a difference in the amphibian communities in different locations across the tea landscape or whether the amphibian communities were better explained by the dominant habitat patches repeated across the landscape. Another goal for this project, was to generate information on the anuran communities in tea plantations in the Munnar area. Ecological studies of anurans are in their infancy in India and my study focused on dominant feature of altered tropical habitats at mid-elevations. I was also interested about the status of Batrachochytrium dendrobatidis $(B d)$, a strong driver of global anuran declines, in this landscape.

Chapter One is a review of all papers comparing amphibian diversity in plantations to amphibian diversity in a natural forest habitat nearby, and a case study of amphibian species richness from four estates in the tea plantation landscape in southern India. From each paper obtained, I extracted information about the age of the plantation, the type of plantation, the type of harvesting employed (complete or periodic), whether it was in a Biodiversity hotspot or not, the number of species in the dominant plantation type, the number of species in the paired forest habitat, and which latitudinal zone the study was conducted in. I found none of these factors affected anuran diversity, except for the type of harvesting, where the plantations which were harvested periodically, like coffee, tea, and cacao had higher amphibian species richness than those that practiced complete harvesting. Using three standard amphibian sampling methods and opportunistic 
encounters during 2012, at elevations between 1500m and 2000m asl in the Munnar district of Kerala, India, I report about the presence of 25 species of anurans. Of these 25 species, nine are from the first three categories of the IUCN Red list. Another nine anuran species were either data deficient or not evaluated. Also, 24 of these species are endemic to Western Ghats and several species from the Rarochestes genus are endemic to the Munnar region of the Western Ghats. The Western Ghats is known to have highly endemic species with narrow ranges of distribution, therefore the presence of 25 species in an old tea plantation landscape, suggests that these old tea plantations in the area are providing some refuge to these species.

In Chapter two, I rated the efficiencies of different standard methods of surveying amphibians in three different habitats (tea, shola forests, eucalyptus forests). I used nocturnal and diurnal, upland Visual Encounter Surveys (VES), Stream Transects (ST), and funnel traps with drift fences. Pit falls traps were discouraged by the plantation managers and hence, were not used. Funnel traps with drift fences are not recommended, as I only encountered four individuals after 64 trap nights in each habitat. Diurnal VESs were discarded after 0 amphibians were encountered. Stream transects in shola forests gave the highest species per person effort, followed by Visual Encounter Surveys in eucalyptus patches. The greatest number of individuals per person-effort was also obtained in the shola habitat. I recommend a combination of nocturnal Visual Encounter Surveys and Stream transects for long-term sampling of anurans in the tea plantation landscape of the Southern Western Ghats, India. 
Using the methods tested in chapter 2, I surveyed amphibian diversity and composition across four sites in the tea plantation landscape of Munnar, India, during the monsoon seasons of two years: 2013 and 2014. There was no significant difference in community structure between 2013 and 2014, and data for the two years was combined in all subsequent analyses. A total of 14 species were encountered in both years. Species from the genera Fejervarya, Micrixalus, and Indirana, as well as, juvenile Raorchestes individuals, were grouped together as they could not be confidently identified in the field and therefore, the species list for the site is conservative because of presence of cryptic species. Of these 14 species, six were in the first three IUCN red list threat statuses and another three were not yet evaluated. I used multivariate statistical methods to determine how anuran communities were organized in the area. There was a difference in the community structure at the four sites that was driven by the presence of exclusive species at some sites. The critically endangered species, Rhacophorus pseudomalabaricus, was encountered only in the Silent Valley site. The species Raorchestes kadalarensis and Duttaphrynus microtympanus were found in low numbers, only in the Rajamalla and Pettimudi site. Transect type (upland Visual Encounter Surveys or Stream Transects) were factors that drove some of the anuran community species similarity. The species Ghatixalus asterops, Micrixlaus sp., and Nyctybatrachus poocha were predominantly found in stream transects at all the four sites across the landscape.

Between 2012 and 2015, I swabbed 216 individuals of 17 species including four critically endangered species to test for the presence of the global and Asian strain of the fungus Batrachochytrium dendrobatidis $(B d)$. Even though six samples showed 
amplification in simple PCR, none of them were positive for $B d$ in triplicate quantitative PCR experiments. Even though we report the absence of the Global and Asian strains of $B d$ in Munnar, Kerala, using the PCR method, it is important to continue monitoring for the presence of chytrid and other infectious diseases. We are in the process of testing the samples with nested PCRs to see if there are any weak signals of the presence of different strains of $B d$ fungus that were missed during our initial molecular work.

My research is the first long term study of anurans conducted in a managed tea plantation landscape of Munnar, India and one of the few ecological studies of amphibians in India. My works lays a baseline for any future anuran community work in the area. I found that because of the variation in studies looking at diversity of amphibians in different plantations around the world, the data did not support any one driver of amphibian diversity in plantations and it is likely that each study outcome was unique because of differences in plantation type, location, age, and management. However, since there were amphibians present in each of the plantations, even though the diversity was poor compared to native forests, plantations should be looked at areas that provide refuge to a subset of the native amphibian pool in an area. We need to increase the number of studies conducted in plantations, and provide the information gathered to the stakeholders who can implement recommendations that may help these resident species. Future sampling and continued monitoring of frogs in plantations will help us manage amphibian populations in agricultural systems. The ideal method for long term sampling in the tea plantation landscape in this area is using stream transects in the small remnant shola forest patches. However, there was one species (Raorchestes jayarami) that was found exclusively in Visual Encounter Surveys in tea fields, and hence my recommendation is 
to study all the habitats available in the landscape. Though this is still a conservative list because of the presence of several cryptic species, it does provide a baseline for future studies in the area. Continued information on the presence, abundance, habitat preferences, community structure, and health of anuran in agricultural systems all over the world can help us better manage these systems. 
VITA

Name: LILLY MARGARET ELUVATHINGAL

Citizenship: Indian

Email: lillymargaret@gmail.com

Birth place: Hyderabad, India

2004-07

2007-09

2009- present

2012-2015

2015- 16

\section{Publications and Presntations}

Eluvathingal, M. L., Shanbhag, B. A., and Saidapur, S. K. (2009). Association preference and mechanism of kin recognition in tadpoles of the toad Bufo melanostictus. Journal of Biosciences. Vol 34, 3: 435-444.

Eluvathingal, M. L., and Karthikeyan Vaudevan. (2013)."Northwestern and Southwestern Ghats Montane Rainforest" in Biomes and Ecosystems: An Encyclopedia. Ed. R.W. Howarth.

Harpalani, M., Parvathy, S., Kanagavel, A., Eluvathingal, L., and Tapley, B. (2015). Note on range extension, local knowledge and conservation status of the Critically 
Endangered Anamalai gliding frog Rhacophorus pseudomalabaricus in the Cardamom Hills of Western Ghats, India. Herpetological Bulletin, 133, 1-6.

'Association preference and mechanism of kin recognition in tadpoles of the toad Bufo melanostictus'. 7-12 July, 2010. American Society of Ichthyologists and Herpetologists. Joint Meeting of Ichthyologists and Herpetologists. Contributed Paper. Providence, Rhode Island, USA.

'A Global Analysis of Factors Driving Amphibian Diversity in Plantations'. 15-19 July, 2015. American Society of Ichthyologists and Herpetologists. Joint Meeting of Ichthyologists and Herpetologists. Contributed Paper. Reno, Nevada, USA.

'Conservation Activities in Tropical Plantations: A Case Study of Tea plantations from the Southern Western Ghats'. 7-12 August, 2016. Invited Symposium. Ecological Society of America Annual Meeting. Fort Lauderdale, Florida, USA. 